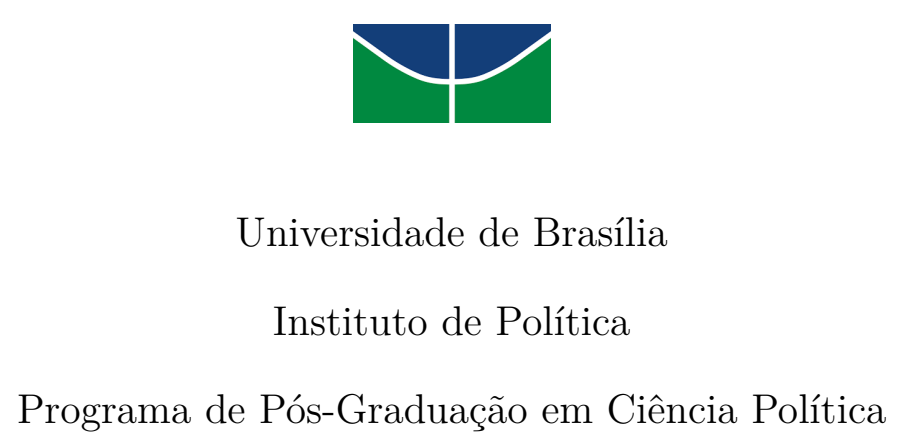

\title{
Para além de esquerda e direita: a multidimensionalidade das crenças no Brasil contemporâneo (1989-2014)
}

\author{
Thiago Moreira da Silva
}

Tese de Doutorado em Ciência Política

Brasília/DF 


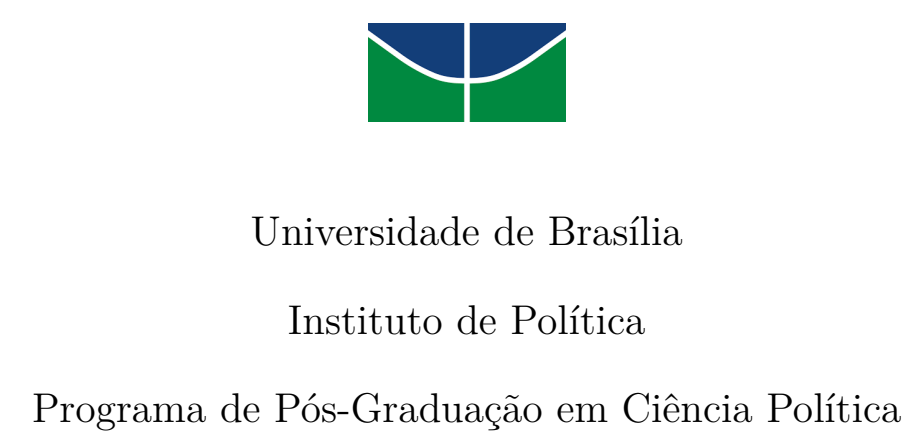

Programa de Pós-Graduação em Ciência Política

Para além de esquerda e direita: a multidimensionalidade das crenças no Brasil contemporâneo (1989-2014)

Thiago Moreira da Silva

Tese apresentada ao Programa de Pós-Graduação em Ciência Política, do Instituto de Política da Universidade de Brasília, como requisito parcial para obtenção do título de doutor em ciência política.

Orientador: Lucio Rennó

Brasília/DF

2017 



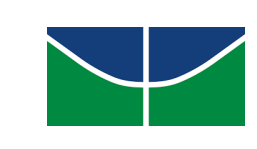

Universidade de Brasília

Instituto de Política

Programa de Pós-Graduação em Ciência Política

\title{
Para além de esquerda e direita: a multidimensionalidade das crenças no Brasil contemporâneo (1989-2014)
}

\author{
Thiago Moreira da Silva
}

Tese apresentada ao Programa de Pós-Graduação em Ciência Política, do Instituto de Política da Universidade de Brasília, como requisito parcial para obtenção do título de doutor em ciência política.

Aprovado pela seguinte banca examinadora:

Prof. Dr. Lucio Remuzat Rennó Jr. (UnB-IPOL)

Orientador

Prof. Dr. Mathieu Turgeon (UnB-IPOL)

Examinador Interno

Prof. Dr. Marisa von Bülow (UnB-IPOL)

Examinador Interno

Prof. Dr. Wladimir Ganzelevitch Gramacho (UnB-FAC)

Examinador Externo

Prof. Dr. André Vitor Singer (USP-FFLCH)

Examinador Externo 
Para que as coisas permaneçam iguais, é preciso que tudo mude.

Trecho de "O Leopardo", romance de Giuseppe Tomasi di Lampedusa. 
Para a "Dona Glória", minha mãe, a quem tudo devo. 


\section{Agradecimentos}

Ao longo do período de doutoramento, muitas foram as acolhidas que obtive. Gostaria, então, de manifestar minha gratidão a algumas e alguns personagens-chave desta trajetória. De início, agradeço ao corpo docente do Programa de Pós-Graduação em Ciência Política da Universidade de Brasília - sobretudo os professores Antônio Brussi, Pablo Holmes e André Borges -, que tiveram atuação definitiva no meu ingresso na disciplina. Reconheço também a contribuição fundamental do professor Lucio Rennó, orientador deste trabalho, que sempre recebeu de maneira solidária e gentil as minhas iniciativas, e Mathieu Turgeon, primeiro a me mostrar o mundo das técnicas quantitativas. A Wladimir Gramacho, pelos excelentes comentários durante o exame de qualificação. Aos demais componentes da banca, Marisa von Bülow e André Singer, pelo pronto aceite e pela certeza de um bom diálogo nos próximos dias.

À UnB, que ofereceu plenas condições de infraestrutura e um ensino de excelência para o desenvolvimento das minhas ideias. Do corpo técnico, agradeço em especial à Thaynara Melo, figura imprescindível no apoio institucional aos alunos da pós-graduação.

À Coordenação da CAPES, financiadora dos meus estudos nesses idos, pelo suporte necessário à minha formação - tanto em âmbito nacional, quanto internacional.

Durante o estágio em Nova York, destaco a relevância do professor Stanley Feldman, que me pôs a par das mais recentes técnicas de pesquisa, tornando possível a operacionalização deste projeto. Fica ainda a minha gratidão às amigas e amigos que viabilizaram minha estada em uma terra sem samba nem futebol. São eles: Marcelo Ribeiro, Luiza Tanuri, "Mafê" Villas-Boas e Luiza Nassif.

Da turma de Brasília, não poderia deixar de citar os companheiros de "peleja", responsáveis por trazer ares mais amenos à secura do planalto central. A Fabrício Bonecini e Gilberto Guerra Pedrosa, que hoje ocupam lugar decisivo no rol das minhas amizades favoritas. A Bel Mesquita, Katia Azambuja, Isadora Harvey, Danielle Kleiner, Igor Brandão, Felipe Corral, Fernando Modelli e Renato Ventocilla. Afinal de contas, os forasteiros reconhecem bem a guarida quando lhes é presenteada.

Do Rio de Janeiro, agradeço os longos e bons papos com Luiz Guilherme Burlamaqui, descoberta do mestrado e interlocutor constante das coisas da vida. A Bruno Lino, pela compreensão e pelo companheirismo dedicados na reta final da tese. À Tamires Alves, por todo o carinho e paciência que me agraciou nos últimos três anos. Aos companheiros de arquibancada e de alento, 
por compartilhar a maior paixão que os seres humanos podem ter: o sentimento clubístico.

A Carlos Eduardo Moreira da Silva [in memorian], o pai que tanta falta me faz.

A Gladstone Chaves de Melo, [in memorian] cujo exemplo "cantando espalharei por toda a parte, se a tanto me ajudar o engenho e a arte".

À Maria da Glória Chaves de Melo, minha mãe, figura maior da minha vida, agradeço a lealdade, a amizade e os constantes estímulos, fundamentais à minha formação pessoal e intelectual. 


\section{Resumo}

Esta tese tem como objeto de análise os entendimentos dos brasileiros sobre os conceitos "esquerda"e "direita", os motivos para a falta de compreensão a respeito desses vocábulos e, por fim, os usos que os eleitores fazem dos sistemas de crenças como guia do comportamento político. Mediante o escrutínio de bases de dados diversas, procura-se destacar a insuficiência de exames anteriores, cujos diagnósticos não atentaram para a ideia de multidimensionalidade das preferências políticas. Nesta investigação destaca-se que o pertencimento com um dos signos se recobre de aspectos valorativos e, sobretudo, simbólicos. Ademais, a estima pela ordem é o valor que melhor afasta os polos em questão - não o modelo de condução da economia ou as inclinações atinentes aos costumes sociais. Por seu turno, o desconforto com os termos está ligado às recentes transformações das estruturas sociais, que trouxeram à tona pautas renovadas de conflitos coletivos. Em vista disso, o aumento das clivagens sociais produziu um cenário no qual preceitos progressistas e conservadores podem se misturar e configurar novos grupamentos ideológicos. A apreciação de concepções convencionais e alternativas revelam a resiliência dos sistemas de crenças como balizador do voto em momentos distintos da história nacional. 


\section{Abstract}

This thesis aims to analyze the understanding of Brazilians about the concepts "left"and "right", the reasons for the lack of knowledge about these words and, finally, the uses that voters make of belief systems as a guide of political behavior. Through the scrutiny of diverse databases, we try to highlight the insufficiency of previous exams, whose diagnoses did not account for the idea of multidimensionality of political preferences. In this investigation it is emphasized that the belonging with one of the signs is derived of evaluative and, mainly, symbolic aspects. In addition, the esteem for order is the value that best departs leftists from rightists - not the conduction of the economy or inclinations regarding social mores. In turn, the embarrassment with the terms is linked to the recent transformations of social structures, which have brought to the fore renewed patterns of collective conflict. In view of this, the increase of social cleavages has produced a scenario in which progressive and conservative attitudes may blend and form new ideological clusters. The appreciation of conventional and alternative conceptions reveals the resilience of belief systems as a predictor of voting in distinct moments of Brazilian history. 


\section{Sumário}

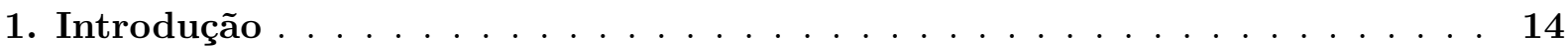

1.1. A transitoriedade semântica dos conceitos . . . . . . . . . . . . . 16

1.2. Os descaminhos da ideologia . . . . . . . . . . . . . . . . . 18

1.3. A elasticidade dos conceitos esquerda e direita . . . . . . . . . . . . . . 26

1.4. Aspectos metodológicos . . . . . . . . . . . . . . . . . . . 31

1.5. Objetivos e estrutura da tese . . . . . . . . . . . . . . 36

2. Aspectos simbólico-afetivos da identificação ideológica . . . . . . . . . . 39

2.1. O desconhecimento semântico das categorias . . . . . . . . . . . . . . . . 41

2.1.1. Outros componentes da identificação ideológica . . . . . . . . . . . . . . . 47

2.2. A escala de autoposicionamento ideológico e os perfis associados . . . . . . . . 49

2.2.1. Os perfis associados ao posicionamento ideológico . . . . . . . . . 51

2.3. Esquerda e direita ou situação versus oposição? . . . . . . . . . . . . . . . . . . 58

2.4. Análise dos componentes ideológicos . . . . . . . . . . . . . . 60

2.5. Valores, símbolos e o contexto histórico . . . . . . . . . . . . . 71

3. As incongruências ideológicas e a multidimensionalidade das crenças políticas 74

3.1. A estrututuração ideológica dos brasileiros . . . . . . . . . . . . . 76

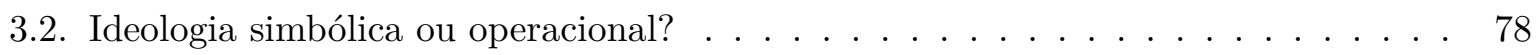

3.3. Pensando de maneira multidimensional . . . . . . . . . . . . . 80

3.4. A análise dimensional . . . . . . . . . . . . . . . . . . . 84

3.4.1. Sofisticação, faixa etária e ideologia . . . . . . . . . . . . . . 92

3.5. As duas vertentes da ideologia . . . . . . . . . . . . . . . . 94

3.6. A incongruência causada pela multidimensionalidade . . . . . . . . . . . . . 97

3.7. Componentes do desajuste ideológico . . . . . . . . . . . . . . . . 98

3.8. Postulados normativos e a multidimensionalidade das crenças . . . . . . . . . 103

4. Nem tão "Flamengo": o diagnóstico alternativo de uma síndrome anteci-

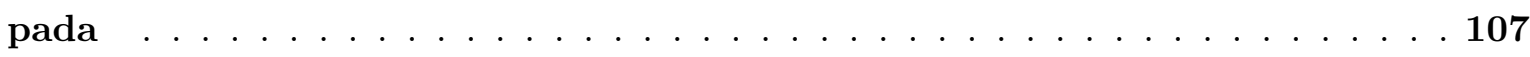

4.1. Perspectivas acerca dos condicionantes do voto no Brasil . . . . . . . . . . . 108

4.1.1. Os diagnósticos alternativos . . . . . . . . . . . . . . . 116

4.2. Os issues e o voto . . . . . . . . . . . . . . . . . . . 118

4.3. A ideologia e voto . . . . . . . . . . . . . . . . . . . 123

4.4. Perfis políticos e sociodemográficos das categorias ideológicas . . . . . . . . . . 128 
4.5. O impacto das categorias ideológicas no voto . . . . . . . . . . . . . . . 135

4.6. Impressões acerca da literatura de comportamento político . . . . . . . . . . . . 141

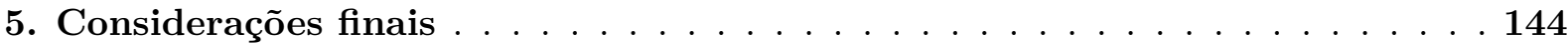

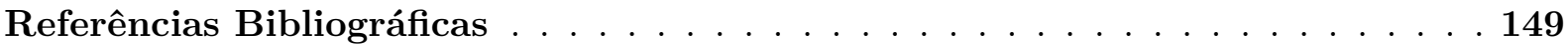

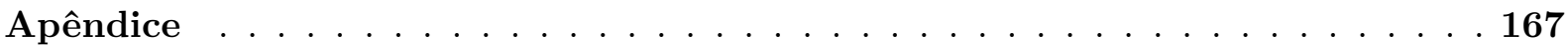




\section{Lista de Figuras}

1. Representação gráfica convencional das técnicas com variáveis latentes . . . 36

2. Série histórica da escala de autoposicionamento ideológico . . . . . . . . 50

3. Percepções de PT e PSDB quanto ao posicionamento ideológico . . . . . . . 59

4. Taxas de não respostas das questões destacadas (1991 e 2014) . . . . . . . . 62

5. Modelo latente com as questões de posição . . . . . . . . . . . . . . 65

6. Modelo latente com os símbolos sociais . . . . . . . . . . . . 66

7. Preditores da identificação ideológica segundo a idade . . . . . . . . . . . . 70

8. Inconsistência entre as ideologias simbólica e operacional . . . . . . . . . . . 91

9. Inconsistência entre as ideologias simbólica e operacional . . . . . . . . . . 96

10. Inconsistência entre as ideologias simbólica e operacional . . . . . . . . . . 98

11. Proporção das categorias ideológicas nos anos de 1993, 2006, 2014. . . . . . 129

12. Cruzamento das vertentes operacional e simbólica da ideologia em 1993. . 130

13. Cruzamento das vertentes operacional e simbólica da ideologia em 2006. . 130

14. Cruzamento das vertentes operacional e simbólica da ideologia em 2014. . . 131

15. Identificação partidária dos grupamentos em 1993. . . . . . . . . . . . . . . 132

16. Identificação partidária dos grupamentos em 2006. . . . . . . . . . . . . 132

17. Identificação partidária dos grupamentos em 2014. . . . . . . . . . . . . . 132

18. Efeitos dos preditores significativos do voto em 1989. . . . . . . . . . 138

19. Efeitos dos preditores significativos do voto em 2006. . . . . . . . . 138

20. Efeitos dos preditores significativos do voto em 2014 . . . . . . . . . 141 


\section{Lista de Tabelas}

1. Perguntas semiabertas sobre o entendimento dos vocábulos . . . . . . . . . . 46

2. Preditores da identificação ideológica . . . . . . . . . . . . . . . . 53

3. Perfis associados às categorias ideológicas (1991). . . . . . . . . . . . 54

4. Perfis associados às categorias ideológicas (2006). . . . . . . . . . . 55

5. Perfis associados às categorias ideológicas (2014) . . . . . . . . . . . 56

6. Preditores do posicionamento ideológico à esquerda e à direita . . . . . . . . 57

7. Correspondência entre as questões de posição e o autoposicionamento ideológico 63

8. Índices de confiabilidade dos itens . . . . . . . . . . . . . . . . 67

9. Preditores do posicionamento ideológico . . . . . . . . . . . . . . . 68

10. Medidas de ajuste comparadas . . . . . . . . . . . . . . . 85

11. Análise dimensional baseada na TRI (WVS 1991 e 2014) . . . . . . . . . . . 88

12. Regressão linear dos preditores da escala de autoposicionamento . . . . . . . 89

13. Medidas comparadas de ajuste segundo a sofisticação política . . . . . . . . 93

14. Medidas comparadas de ajuste segundo a idade . . . . . . . . . . . . . 94

15. Preditores da inconsistência ideológica . . . . . . . . . . . . . . . 102

16. Determinantes do voto no Brasil . . . . . . . . . . . . . . . 121

17. Medidas comparadas de ajuste dos modelos de LCA . . . . . . . . . 127

18. Classes latentes extraídas das preferências políticas . . . . . . . . . . . 128

19. Perfis associados às categorias ideológicas (CP 1993) . . . . . . . . . . 133

20. Perfis associados às categorias ideológicas (LAPOP 2006) . . . . . . . . . . 134

21. Perfis associados às categorias ideológicas (LAPOP 2014) . . . . . . . . 135

22. Categorias ideológicas e voto $(\mathrm{CP} 1989) \ldots \ldots$. . . . . . . . 137

23. Categorias ideológicas e voto (LAPOP 2006) . . . . . . . . . . . 139

24. Categorias ideológicas e voto (LAPOP 2014) . . . . . . . . . . . 140

25. Cultura Política 1993 e ESEB 2002 . . . . . . . . . . . . . . . 179

26. ESEB 2006, LAPOP 2010 e LAPOP 2014 . . . . . . . . . . . . . . 180

27. Cultura Política $1993 \ldots \ldots$. . . . . . . . . . . . . . 181

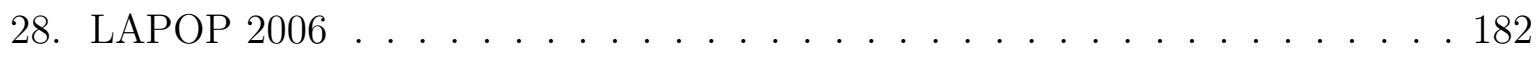




\section{Introdução}

Mankind have many ideas, and but few words.

- Stuart Mill, Use and abuse of political terms (1832).

O principal evento de novembro de 1989, a queda do Muro de Berlim, pôs a baixo não apenas a barreira de concreto que separava os alemães em orientais e ocidentais, mas sinalizou o fim de uma guerra que atravessou toda a segunda metade do século XX. As imagens de populares empenhados em derrubar a divisória com as próprias mãos logo repercutiram nos veículos de comunicação do mundo inteiro, que tratavam o episódio como a vitória do povo contra os desmandos de um Estado autoritário. Com efeito, a cena representava uma construção simbólica particular: o êxito de um pensamento hegemônico, cujo mote repousava na união do capitalismo de livre-mercado com uma suposta liberdade provocada pela abertura política. Na esteira daquele acontecimento, diversos analistas propagavam ideias de desfecho: da história, como popularizou Fukuyama (1992), e, também, das ideologias (Jost, 2006) ${ }^{1}$.

Não obstante, as brisas dos tempos atuais trouxeram consigo um sopro de renovação em relação ao interesse dos cientistas políticos pelos construtos ideológicos. Isso porque, passados quase trinta anos do evento que inaugura a presente tese, o mundo volta a testemunhar um contexto turbulento, permeado pela desconfiança acerca de uma formulação democrática de baixa intensidade e por projetos políticos alternativos ao até agora soberano empreendimento liberal.

Por um lado, vemos o descrédito dos cidadãos comuns com o declínio substantivo do comparecimento eleitoral, o desalinhamento partidário e a ampliação da desconfiança com as instituições tradicionais (Miguel, 2000). Por outro, o surgimento de respostas à esquerda e à direita à teleologia de Fukuyama: movimentos de ocupação em diversas cidades do globo; referendos atinentes aos blocos comerciais; experiências progressistas de legendas partidárias na América Latina e na periferia da continente europeu; ascensão

\footnotetext{
${ }^{1}$ Ainda que a queda do Muro de Berlim tenha contribuído para postular a ideia de "fim da ideologia", Jost (2006) mostra que profecias do tipo já haviam aparecido com o fim da Segunda Guerra Mundial. O tema, inclusive, será discutido nas linhas subsequentes.
} 
da extrema-direita em países da Europa dita "central" e a eleição de Donald Trump à presidência dos Estados Unidos.

Para dar conta dos desdobramentos políticos recentes, os exames sobre as ideologias, em sentido plural, voltaram à tona nos trabalhos acadêmicos. A emergência da dimensão sociocultural como clivagem importante (Fiorina, et al., 2005) e o reconhecimento que os cidadãos possuem crenças mais estruturadas, em contraposição ao sentenciado em outros idos (Peffley e Hurwitz, 1987; Feldman, 1988; Ansolabehere, et al., 2008) servem ainda de novos atrativos para a investigação do conceito.

As linhas seguintes desta pesquisa tentam, por conseguinte, cumprir a prescrição de atualizar os entendimentos e os enlaces desses sistemas de crenças compartilhados, que funcionam aos moldes de heurísticas, orientando os julgamentos e desempenhando o papel de dispositivos motivacionais, a fim de justificar e estruturar cognitivamente as questões de cunho coletivo (Jost et al., 2013). Esta tese, portanto, tem como objetivo investigar os entendimentos dos brasileiros sobre os conceitos "esquerda"e "direita", analisar os motivos de possíveis incompreensões dos vocábulos e examinar até que ponto os eleitores usam a ideologia como guia do comportamento político.

O trabalho, atento aos rótulos ideológicos no Brasil contemporâneo, investe na ideia de um alargamento dos vocábulos esquerda e direita sem, contudo, pleitear a exclusão das categorias da gramática e dos diagnósticos da ciência política. Para tanto, destaca-se a relevância de uma outra forma de concepção da metáfora espacial. Em vez de um contínuo binário e mutuamente excludente (Bobbio, 2001), argumenta-se em favor da multidimensionalidade dos conceitos - ou seja, de um formato sobreposto, no qual os espectros possam se combinar em âmbitos distintos. Ao contemplarmos a interseção desses alinhamentos, temos a possibilidade de ponderar de maneira mais matizada o desenrolar dos acontecimentos políticos dos dias atuais. Dito de outro modo, é afirmar, de um jeito realista, a capacidade das pessoas de organizarem suas crenças combinando inclinações progressistas e conservadoras a respeito de temas diversos.

Aqui, retratam-se os sentidos e os usos ideológicos desenvolvidos pelos cidadãos brasileiros nas últimas três décadas. Um cenário, de imediato, pouco afeito a manifestações do tipo, em virtude de composições institucionais desfavoráveis, arrogado consenso dos especialistas em torno de políticas econômicas de viés liberal, baixos níveis de ins- 
trução da população, alto grau de desigualdade social e, consequentemente, um modelo de gestão dos bens públicos alicerçado em práticas clientelistas. Os resultados levantados na tese, no entanto, reforçam o oposto: uma marcada capacidade de estruturação das preferências e de aplicação das ideologias no comportamento político dos cidadãos em geral.

Antes, contudo, convém recorrer de forma concisa a um misto de história dos conceitos com os debates anteriormente elaborados na ciência política e na psicologia política, visando deslindar a trajetória sinuosa dos termos, surgidos durante a Revolução Francesa e presentes até hoje no catálogo de análise dos pesquisadores sociais - sem, claro, ter em vista a pretensão de um exame exaustivo das categorias. Aos leitores mais inquietos, fica a certificação de que esse sobrevoo se justifica devido à multiplicidade de significados assumidos pelas expressões no decorrer dos anos e, portanto, ajuda a esclarecer as formulações adotadas nos capítulos posteriores.

\subsection{A transitoriedade semântica dos conceitos}

Desenvolver uma tese sobre conceitos ligados a um emaranhado semântico, certamente, não é tarefa das mais fáceis. E, por isso mesmo, a investigação do entendimento dos vocábulos esquerda e direita e dos ditames da ideologia no comportamento político dos brasileiros preenchem os requisitos necessários à organização de um trabalho acadêmico.

Verdade seja dita, sempre existirá um certo hiato entre os conteúdos sociais e os usos linguísticos utilizados para fixar seus significados. Em outras palavras, as transformações societais raramente correspondem a mudanças imediatas nos sentidos das descrições que as acompanham. Essa interface compreende cenários variados, compostos de significantes moribundos, neologismos pouco conhecidos do grande público e de acontecimentos não catalogados por especialistas ou leigos.

O fato, contudo, não deve estabelecer uma separação por completo dos eventos transcorridos e seus condicionantes vocabulares, mas redobrar nossa atenção às variações semânticas impostas pela particularidade de contextos culturais e/ou conversões provocadas pelo passar dos anos. Conforme Koselleck (1989), "toda língua é historicamente condicionada, e toda história é linguisticamente adaptada"(tradução livre) (1989: 649). 
A divergência diz respeito à temporalidade dessas interações: a semântica anda em ritmo mais lento se cotejada às aceleradas mutações no ordenamento social, especialmente em tempos atuais.

Assim, o passo vagaroso da linguagem - e, consequentemente, sua maior durabilidade - permite aos conceitos a aparição em conjunturas e momentos históricos dessemelhantes. E representa, muitas vezes, uma relação conflituosa. Isso porque, embora o número de palavras seja necessariamente limitado, a substância de suas traduções ideias, sujeitos, possibilidades e acontecimentos - são potencialmente infinitos.

Por conseguinte, os conceitos mantêm como suposto fundamental a ideia de diacronia - isto é, uma mesma palavra pode permanecer inalterada e, ainda assim, o conteúdo expresso por ela modificar-se de forma significativa. Isto posto, eles se articulam com o contexto histórico ao qual estão inseridos - indicando, portanto, algo situado para além dos fenômenos linguísticos. Nesse ínterim, os vocábulos sociopolíticos podem ser aplicados como indicadores de inflexões de diferentes matizes. Para Jasmin (2006), entretanto, esse intercâmbio não tem por objetivo revelar a história dos conceitos em si, mas a história da recepção que tiveram. Recepção esta sujeita às mais diversas incompreensões em virtude dos desvios e das ocultações, conscientes ou não, das transposições da linguagem.

A noção básica de diacronia torna necessária, pois, a distinção entre "palavras"e "conceitos"(Koselleck, 1989). De maneira sintética, se as palavras podem seguir caminhos inequívocos, os conceitos inequivocamente percorrem trajetos sinuosos - haja vista que as primeiras só se convertem nos seus correlatos quando condensam a inteireza (ou pelo menos parte substantiva) de uma conjuntura específica. Não por acaso, ao agrupar a variedade da experiência histórica em uma coleção de referências teóricas e práticas, estes estão mais suscetíveis à incompreensão dos indivíduos.

Por outro lado, a função semântica e a performance dos vocábulos não são apenas um mero derivativo de circunstâncias exógenas relacionadas, mas um fator estruturante dos espaços culturais e políticos, bem como dos horizontes de expectativas atinentes a ambos. Ainda em Koselleck (2004), "epistemologicamente, isso implica que nada pode ocorrer historicamente sem ser apreendido conceitualmente" (2004: 86).

E esse trânsito de mão-dupla certamente aplica-se à noção de ideologia, a seus 
resultantes - os paralelos esquerda-direita - e aos principais objetos de investigação das ciências sociais - Estado, classe, ordem, mercado, revolução, entre outros. Continuemos, então, com os objetos de exame deste trabalho.

\subsection{Os descaminhos da ideologia}

Como foi dito, as categorias sob análise surgiram nos embates decorrentes da Revolução Francesa, no final do século XVIII. A primeira aparição do termo ideologia, ao que parece, foi no Institut National des Sciences at Arts de Paris, em 1796, cunhada pelo Conde Antoine Louis Claude Destutt de Tracy (Sartori, 1969; Knight, 2006; Jost et al, 2008; Strath, 2013). A criação da instituição pretendia prover à França um sistema de ensino superior comprometido com os valores filosóficos atinentes ao iluminismo. Quando elaborou a expressão, o autor de Elements d'Ideologie (1901) tinha em vista a promoção de uma nova ciência, baseada no estudo das ideias.

A crença iluminista de que os elementos comuns às sociedades obedeciam a padrões universais e regulares, tais como nas ciências da natureza, sedimentava o entusiasmo do corpo de intelectuais em busca de leis comuns, próprias às interações humanas. Tão logo, o grupamento de estudiosos ganharia a alcunha de "ideólogos", conhecidos pela postura que os colocava em um meio-termo entre os opositores de postulados metafísicos e os críticos dos interesses materiais sobre os quais a sociedade pós-revolucionária repousava.

A associação entre ideologia e ciência teve vida curta, contudo, e cedo adquiriu um sentido pejorativo. O século XIX ainda engatinhava no momento em que Napoleão Bonaparte, então Imperador, transformou o conceito, inicialmente acadêmico, e inaugurou um novo campo semântico, ligado a concepções depreciativas (Strath, 2013).

A simpatia inicial da liderança com o grupo - na campanha do Egito, por exemplo, Napoleão edificou um instituto inspirado no congênere francês na cidade do Cairo - daria lugar a um enfrentamento público e, consequentemente, a um novo entendimento da matéria. Motivado pelo antagonismo de Tracy e companhia às suas ambições imperiais e aos vínculos costurados com as elites tradicionais - notadamente, a Igreja Católica , o soberano acusaria o círculo de pensadores de manterem imaginários divorciados da realidade, distantes das práticas pertencentes ao jogo de poder. Desse momento em 
diante, ideologia passaria a guardar um sinônimo pouco elogioso, conotando a interferência injustificada da teoria filosófica nas práticas políticas. O vocábulo convertia-se em um rótulo para expressar princípios irrealistas, inadequados às esferas de governo e de ação dos representantes.

Essa direção renovada, que transfigura o termo em ilusão é também atribuída aos trabalhos concebidos por Marx (Konder, 2002; Sell, 2006; Strath, 2013). Em A Ideologia Alemã (2007), Marx e Engels desenvolveram uma crítica intensa aos jovens hegelianos, em especial a Feuerbach. Conforme os autores, o idealismo seria o principal obstáculo para o entendimento dos construtos ideológicos, pois os seguidores de Hegel estavam sujeitos a uma miragem, segundo a qual a imaginação, os pensamentos e os conceitos determinavam as relações sociais e a história da humanidade. Em uma metáfora, sustentaram o suposto de que a ideologia funcionaria aos moldes de uma "câmara obscura" - espécie de dispositivo ótico formatado para projetar as imagens de seu entorno de cabeça para baixo, preservando a perspectiva original em uma tela interna.

Cumpre ressaltar que o edifício do pensamento marxiano baseia-se na percepção que a produção intelectual dos indivíduos é condicionada pelas relações de produção e põe à tona duas fontes diversas da estabilidade social: os mecanismos repressivos e os não repressivos. A ideologia se adequaria ao segundo princípio ao transmitir convicções falsas sobre as condições de vida da sociedade, beneficiando a classe economicamente dominante. Se nas ofensivas de Napoleão as ideias estariam descoladas da realidade; na compreensão marxiana, elas ocupam um papel igualmente secundário, conquanto subordinadas a condicionantes materiais. Nesse sentido, o conceito assume uma roupagem orientada para a dissimulação da dinâmica de exploração de classe existente na sociedade. Ao arrogar o título de falsa consciência, referenda um acúmulo de representações enganosas associadas aos interesses das classes superiores, com o objetivo de legitimar a opressão.

Embora essa seja a versão predominante de leitura dos escritos de Marx a respeito do assunto, Geuss (1981) salienta a existência de, pelo menos, três variantes do termo em A Ideologia Alemã: uma descritiva, envolvendo o estudo das crenças e rituais característicos de certos grupos sociais; outra positiva, como visão de mundo proveniente dos membros de ordenações, com um senso de pertencimento ou identidade; e, por fim, a rubrica crítica acima descrita, enfatizando a subjugação dos indivíduos diante da falsa 
consciência e de formas ilusórias de pensamento. Na mesma direção, Leopold (2013) pontua os entendimentos do autor sobre o conceito como incipientes e opacos - sujeitos, portanto, a interpretações distintas e, até mesmo, contraditórias ${ }^{2}$. Leopold destaca ainda que, por ter sido pouco desenvolvido, o vocábulo denota significantes dessemelhantes na tradição marxista posterior, sublinhando as disposições divergentes contidas nas teorizações de Mannheim, Gramsci e Althusser.

Em Ideologia e Utopia (1956) - obra que deu origem à sociologia do conhecimento -, Mannheim suscita o pressuposto produzido por Marx de que as ideias surgem no contexto da existência social, isto é, nossas perspectivas políticas são organizadas pelas configurações concretas nas quais elas se moldam. Em oposição, no entanto, admite uma atribuição ativa das mesmas - com dimensões psicológicas e sociais - e não um papel exclusivamente voltado à manipulação. A dimensão psicológica refere-se à integração inconsciente, capaz de guiar o pensamento e a ação dos cidadãos; ao passo que socialmente os construtos ideológicos servem à expressão de grupos sociais mediante a performance de ritos e mitos compartilhados. Desse ponto de vista, eles não representavam desmembramentos entre uma suposta verdade e os conteúdos integrantes da realidade.

Posteriormente, Gramsci modificou a compreensão marxista do conceito em diferentes direções. A hegemonia ideológica poderia ser exercida por uma classe dominante não como um reflexo imediato das relações de produção, mas ao constituir o resultado de uma construção cultural da comunidade por intelectuais, com capacidade de administrar o consentimento mediante coordenação de interesses e ideologias diferentes e conflitantes.

Para Althusser (1980), seguindo Marx, existe uma divisão clara entre ideologia e ciência. No entanto, o autor ressalta a importância da primeira como um sistema de representação para a conformação associativa dos indivíduos e, da segunda, como um procedimento teórico. A eficácia prática do conceito em questão figura na medida de seu sucesso em cimentar as pessoas nos papéis sociais a elas destinados por estruturas particulares. Dito de outro modo, a ideologia exerce a função de assegurar que os membros da sociedade sejam devidamente equipados para responder às exigências de suas condições de existência. As condições de seu emprego exigem uma multiplicidade de aparelhos próprios

\footnotetext{
${ }^{2}$ Outra referência sobre o entendimento nos estudos marxistas do conceito de ideologia é o trabalho de Konder (2003).
} 
ao Estado - casos da Igreja, escolas, universidades, família, sindicatos, partidos, empresas, jornais, etc. Nessas instituições, ao contrário da ação estatal, a violência ocupa uma posição coadjuvante. Ao defender que "as ideologias não 'nascem' desses aparelhos, mas das classes sociais em luta"(Althusser, 1974: 101), Althusser expõe sua concepção do vocábulo alicerçada na pluralidade dos embates sociais e, consequentemente, no reconhecimento de composições diversas das crenças sociais.

Não obstante, a compreensão pejorativa também aparece em pensadores localizados no outro polo do espectro ideológico. Logo depois da Segunda Guerra Mundial, momento em que alguns pesquisadores defendiam o afastamento de compromissos particulares (diga-se, ideológicos) e um caráter mais objetivo das ciências sociais, Sartori (1969) expressou todo o seu ceticismo em relação ao conceito, associando-o a um encargo eminentemente autoritário e potencialmente dispensável. Propôs, em seguida, a diferenciação entre sistemas de crenças ideológicos e sistemas de crenças pragmáticos: enquanto os últimos seriam guiados por um sentido utilitário e aberto a revisões em virtude da experiência, os primeiros privilegiariam traços dogmáticos, afeitos à teoria e não à empiria, e resistentes a possíveis reconsiderações posteriores. Se Tracy havia intentado a criação de uma ciência para desvelar as superstições, sua criatura ganhava feições completamente opostas nesse período.

Naqueles idos, as reorientações acadêmicas acompanhavam a modificação das estruturas de poder impostas pela nova geopolítica. O ambiente trazia consigo, e de maneira seminal, a tese do "fim da ideologia" (Strath, 2006; Jost, 2006). Entre seus principais postulantes, Daniel Bell, Seymour Lipset, Edward Shils e Raymond Aron comungavam da perspectiva que as ideias radicais tinham perdido força nos países industrializados do Ocidente. Embora o lado soviético tenha saído revigorado do enfrentamento, os autores acreditavam que o bloco comunista não oferecia grandes ameaças às nações da Europa Central e aos Estados Unidos, onde havia triunfado uma forma pragmática e socialmente responsável do liberalismo econômico. Nas palavras de Bell:

Few serious minds believe any longer that one can set down "blueprints" and through "social engineering"bring about a new utopia of social harmony. At the same time, the older "counter beliefs" have lost their intellectual force as well. Few "classic"liberals in- 
sist that the state should play no role in the economy, and few serious conservatives, at least in England and on the continent, believe that the Welfare State is the "road to serfdom". In the Western world, therefore, there is today a rough consensus among intellectuals on political issues: the acceptance of a Welfare State, the desirability of decentralised power; a system of mixed economy and pluralism. In that sense, too, the ideological age has ended (1960: 397).

Se os matizes ideológicos ganham relevância em épocas de polarização dos estratos sociais, seus contornos borravam de uma forma aparentemente definitiva. O consenso em torno do Estado de Bem-Estar Social alimentava a convicção de que essa formulação econômica, combinando liberalismo e socialismo, resultaria no declínio da hostilidade entre os mundos oriental e ocidental.

Analogamente, o descompasso com os acontecimentos-chave dos períodos anteriores - a emergência do socialismo na URSS, as turbulências provocadas pelo crash da Bolsa de Nova York, o nazismo e o já citado conflito mundial - terminaria por levar a uma ruptura epistemológica marcante nas ciências humanas: a chamada "revolução behaviorialista"3 - alavancada, sobretudo, por financiamentos governamentais, materializados em organismos como as Fundações Ford e Rockfeller e o Social Science Research Foundation (Blyth, 2006; Peres, 2008). Na ciência política, em particular, o paradigma behavioralista postulava um tipo de abordagem em oposição ao antigo institucionalismo, ou seja, uma formulação teórica positiva, indutiva e direcionada empiricamente. Ademais, tomava de empréstimo as proposições de outras áreas de conhecimento - casos da sociologia, psicologia e economia. Na busca por maior cientificidade, a abordagem introduzia uma miríade de novos elementos conceituais, ao passo que incorporava as técnicas estatísticas aos desenhos de pesquisa, agregava o método comparativo aos horizontes de investigação, assumia o axioma das descrições objetivas e explorava as generalizações e uniformidades do comportamento político.

\footnotetext{
${ }^{3}$ Segundo Feres (2004), a tradução behavioralista adequa-se melhor aos acontecimentos daqueles idos, já que compreende uma distinção mais acertada do movimento da psicologia comportamental liderado por B. F. Skinner.
} 
De imediato, os behavioralistas estadunidenses haviam ignorado os pressupostos da tese do fim da ideologia. Mediante estudos calcados em votações nominais, discursos de legisladores, juízes e demais atores do universo político, os pesquisadores identificaram uma dimensão extra partidária que compunha a interface das lideranças, sustentada pela coesão de opiniões a respeito de matérias coletivas - ligadas, notadamente, aos rumos dos programas relacionados ao New Deal ${ }^{4}$, instituído por Franklyn Roosevelt na década de 1930. Talvez o mais famoso desses trabalhos tenha sido conduzido por Duncan McRae (1952) - o primeiro a lidar com os construtos ideológicos de forma quantitativa - quando constatou a divergência entre parlamentares na Assembleia Legislativa do estado de Massachussets (Knight, 2006).

Desenvolvimentos posteriores, no entanto, puseram em questão a efetividade do conceito para informar o comportamento dos cidadãos comuns. O panorama descrito mudaria de vez no final dos idos de 1950, quando um grupo de pesquisadores da Universidade de Michigan, capitaneado por Angus Campbell, expôs importantes aportes aos estudos dos determinantes do voto em solo norte-americano. Nesse modelo de pesquisa, o indivíduo constituía-se como a unidade central de análise, mediante a qual são colhidas informações com o objetivo de compreender as motivações e crenças das pessoas. Para chegar diretamente aos agentes, uma técnica de coleta de dados por amostragem, o survey, dava carne às investigações apoiadas na corrente psicossociológica ${ }^{5}$.

O despertar da metodologia enunciava que "indivíduos semelhantes do ponto de vista social e de atitudes tendem a ter comportamentos políticos semelhantes, a votarem na mesma direção, independente dos contextos históricos" (Figueiredo, 2008: 26). Se as respostas das urnas suscitavam limitações e apenas divulgavam os retornos dos sufrágios, o procedimento ajudava a perceber como e por que ocorriam os desenlaces eleitorais. O resultado era decepcionante: ao contrário das elites do sistema representativo, o restante da população não conseguia manejar as manifestações ideológicas com desenvoltura

${ }^{4} \mathrm{O}$ New Deal foi o nome dado aos programas implementados por Roosevelt para lidar com as crises provocadas pelo liberalismo na década anterior. Os programas tinham uma inspiração intervencionista e podem ser incluídos na categoria das formas mistas de direção econômica descritas na página anterior.

${ }^{5}$ Basicamente, os estudos de comportamento eleitoral baseiam-se em três correntes explicativas: a da escolha racional, a abordagem sociológica e a perspectiva psicossociológica. Sobre o assunto, ver Castro (1992) e Figueiredo (2008), dentre outros. 
(Campbell, et al., 1960; Converse, 1964).

Esses achados iam de encontro às concepções prévias desenvolvidas pelas matrizes sociológica e da escolha racional - cujos expoentes eram Lipset e Downs, respectivamente. Em Political Man (1963), Lipset chegou à conclusão de que a ascendência do grupo ao qual pertence o eleitor contribui para justificar sua escolha partidária. Haveria, então, não uma ligação imediata, mas uma tendência associativa das classes sociais com determinadas legendas. Mais do que isso: existiria um vínculo estável entre a conformação estrutural da sociedade e o posicionamento ideológico dos cidadãos num espectro esquerda-direita. Portanto, a ideologia teria por mote revelar ao eleitorado o papel dos partidos no jogo político.

Apesar de partir de pressupostos distintos, Downs (1957) apresenta um desfecho análogo. O modelo espacial adaptado pelo autor remete aos argumentos teóricos concebidos pelos economistas, com o objetivo de explicitar a relação entre a localização de lojas concorrentes em uma via movimentada e a reação dos consumidores. Tal qual lojistas e clientes, partidos e indivíduos buscam maximizar seus benefícios e reduzir os custos de atuação. Aqui, diferente de Lipset, o voto não enseja a conformação de ditames coletivos, mas baliza as escolhas racionais de escopo individual. Na ânsia por reduzir prejuízos, os eleitores têm na ideologia uma linguagem sintética, um atalho, capaz de condensar o conhecimento necessário ao engajamento político. Portanto, ambos os lados da dinâmica espacial usam a heurística como um farol: os primeiros ao procurar uma localização vantajosa dentro do domínio esquerda-direita, com o fito de atrair o maior número de simpatizantes; enquanto os últimos contam com esse auxílio para diferenciar legendas competidoras segundo emblemas mais compreensíveis.

As divergências entre as três correntes, contudo, desaguam em um mesmo estuário: de entendimento positivo e pluralista dos elementos ideológicos - que, diga-se, não ficou represado na ciência política e seguiu pelos afluentes das ciências sociais. Ademais, nessa época ganhou força uma vertente funcionalista do vocábulo. Na antropologia, Geertz (1989) esclarece o funcionamento das ideologias como mapas culturais, isto é, conjuntos de símbolos que tornam compreensíveis as situações sociais para os participantes da vida em comunidade. Geertz via o conceito à maneira de um problema subjacente de dissonância social, causado pela secularização e pelo rompimento de uma ordem tradicional. Assim, 
seria um componente essencial da hodierna estruturação dos laços humanos. Na mesma direção, Freeden (2001), na sociologia, concebe a dimensão imaginativa e inventiva da noção em voga, a fim de dar conta das representações da realidade social. A ideologia serviria, sobretudo, como instrumento de gestão das sociedades e de seus processos fornecendo quadros negociados de socialização com o propósito de justificar as condições sociais existentes ou de propiciar ferramentas para sua transformação.

Na história, Koselleck (1999) analisou a formação da polarização ideológica que guiou os acontecimentos estruturantes da Segunda Guerra. Em sua tese de doutoramento, o autor examinou de forma pormenorizada o modo como os conceitos liberdade e igualdade - originários, e mantidos unidos, durante a Revolução Francesa - cindiram ao longo do século XIX e deram corpo aos dois principais ramos ideológicos do centenário passado: o liberalismo e o socialismo. Responsáveis, por conseguinte, pela patogênese da sociedade burguesa: um encadeamento marcado pelo sofrimento em virtude dos confrontos religiosos e revolucionários.

Cumpre informar, todavia, que as concepções passadas e os desdobramentos contemporâneos do termo não seguem uma conformação linear, com os sentidos pretéritos cedendo comodamente o lugar para os novos significantes. Os conceitos são, inversamente, resultados de lutas dialógicas abertas e incertas e, por vezes, ocupam espaços sobrepostos - como foi o caso das múltiplas acepções concernentes à ideologia. Lembrando Lynn Hunt (2007), a linguagem não reflete as condições das inflexões revolucionárias, mas é sujeita também às transformações inerentes ao decurso da revolução. Por conseguinte, o campo semântico está sujeito a batalhas discursivas suscetíveis a toda sorte de contingências.

Apesar das variadas definições, Knight (2006) sustenta que os autores que trabalham com o termo não chegaram a edificar uma "Torre de Babel", tornando-se assim possível pensar em consensos mínimos. Com efeito, revela como quase todas as teorizações levam em conta as noções de coerência, estabilidade e contraste. Ou seja, ideologia implica uma coesão entre convicções relacionadas entre si, relativamente persistentes no tempo e opostas a outros sistemas de crenças. 


\subsection{A elasticidade dos conceitos esquerda e direita}

A propósito, a busca por acordos mínimos talvez seja a melhor alternativa para enfrentar o terreno pantanoso no qual os paralelos esquerda e direita se assentam. Não obstante, a tarefa aqui parece ainda mais complicada. Muitos foram os significados atribuídos ao contínuo em diferentes países e ao longo do tempo, desde que deputados oposicionistas e situacionistas se dividiram na Assembleia Nacional da França em 1789. De certeza, tem-se somente a convicção de que a metáfora espacial não se constitui a priori. Isso porque a divisão de delegados apoiadores e opositores do antigo regime na França, marco fundador dessa simbologia, guarda pouca similitude com os rumos posteriores percorridos pelos vocábulos. Conforme Tarouco e Madeira (2013):

A distinção original entre defesa da ordem ou da mudança correspondia a uma disposição espacial e ao longo do século XIX na Europa a distinção entre esquerda e direita passa a ser associada com a distinção entre liberalismo e conservadorismo. Com a expansão do movimento operário e a difusão da perspectiva marxista o conteúdo da posição de esquerda passa a incorporar a defesa dos interesses da classe proletária. Com os debates da socialdemocracia no final do século XIX e a revolução russa de 1917, a defesa do capitalismo desloca a burguesia para a direita. A emergência do keynesianismo a partir da década de 1930, por sua vez, e dos estados de bem-estar social com suas políticas redistributivas, reforçaram a oposição entre a liberdade de mercado e o Estado interventor, deslocando também o liberalismo para a direita (Idem, 2013: 3).

Além do embate relativo à forma ideal de condução da economia, o surgimento de questões pós-materialistas nos anos 1960 (Inglehart, 2007) e, posteriormente, o colapso do socialismo no bloco soviético já no final do século (Jost, 2006) contribuíram para consubstanciar uma confusão conceitual sem soluções fáceis. De antemão, porque o próprio ajuste econômico, entendido como aspecto principal da separação dos espectros políticos, não guarda constância nos conflitos sociais de diferentes regiões.

Ao inventariar os critérios de distinção ideológica em territórios variados, Klinge- 
mann (1979), por exemplo, observou a variação acentuada entre os países, e no interior dos mesmos, na forma como a distinção havia sido interpretada pelo público: muitos respondentes eram incapazes de dar algum significado substantivo aos termos, alguns trocavam as acepções, uns poucos tinham uma compreensão mais voltada a valores, outros a entendimentos morais ou afetivos, enquanto a maioria via os dísticos como símbolos relativos a partidos ou segmentos sociais. Sani e Sartori (1983) mostraram que o contínuo se correlaciona fortemente com atitudes ligadas à igualdade, à mudança, à Guerra Fria, às concepções religiosas, aos grandes negócios e à polícia. Evans (1993) encontrou uma estreita conexão da ideologia com as políticas de gênero, sugerindo que a linha divisória tinha absorvido novos elementos. Recentemente, Benoit e Laver (2006), arguindo especialistas locais em um estudo multinacional, notaram as distinções programáticas e a insuficiência dos termos esquerda e direita para predizer o posicionamento de legendas partidárias orientais - casos de Japão, Turquia e Israel.

Dada a multiplicidade de orientações assumidas pelos conceitos em contextos diversos, alguns autores optaram por enquadramentos de tipo sociológico, e não inerente a issues. Nesse caso, leva-se em consideração a abordagem de Gibson (1996), segundo a qual o horizonte da direita está vinculado, necessariamente, a um estrato social determinado, a saber, as camadas mais altas da sociedade. Sem maiores delongas, a comprovação empírica desse argumento no Brasil não resistiria a qualquer contrafactual mais exigente: notadamente, são os mais pobres que costumam sustentar as hostes conservadoras (Dyck e Montero, 2015).

Fato é que a agenda política foi extensamente alargada a partir dos anos 1960. Os movimentos sociais, naqueles idos, sedimentaram uma série de pautas não consideradas por gerações anteriores ${ }^{6}$ : as lutas em torno dos direitos civis - das mulheres, dos negros, da população LGBTT -, os conflitos baseados em hábitos sociais desfigurados e a sedimentação das causas ambientais (Laclau, 1986; McAddam et al., 2005; Della Porta e Diani,

\footnotetext{
${ }^{6}$ Não se pode dizer que esses movimentos tenham, de fato, emergido na cena pública nos anos 1960 . Segundo a literatura especializada, os primórdios do feminismo, por exemplo, remetem ao século XVIII, quando a inglesa Mary Wollstonecraft reivindicou pela primeira vez às mulheres os direitos atribuídos aos homens pelo pensamento liberal (Birolli e Miguel, 2015). O que se pretende reforçar é a ebulição simultânea e maior publicização das lutas sociais ocorridas nessa década, que concorreram para dilatar as agendas públicas contemporâneas.
} 
2009). Nos Estados Unidos, palco central das transformações da época, os confrontos pontuados pelo aborto, ação afirmativa, modificação dos cânones artísticos, homossexualidade, preceitos familiares e de autoridade em geral, multiculturalismo, pornografia, educação escolar e sexual receberam a alcunha de "guerras culturais" (Hartman, 2015).

Com efeito, todas essas reivindicações somaram-se às questões econômicas e contribuíram para converter os paralelos esquerda e direita em um grande emaranhado de contendas sem articulações precisas. Afinal, nada indica que alguém afeito à livre atividade do mercado tenha de ser, necessariamente, contra os direitos das mulheres, o aborto ou o casamento entre pessoas do mesmo sexo.

Por outro lado, se o fim da Segunda Guerra colocou em maus lençóis o liberalismo, os últimos anos do século XX tiveram efeito inverso e puseram em xeque as concepções intervencionistas após a queda do Muro de Berlim e o desmantelamento da União Soviética $^{7}$. A crise de projetos políticos à esquerda proporcionou um intenso debate intelectual, cujos principais representantes foram Anthony Giddens (1994) e Norberto Bobbio (1996). Conforme o autor inglês, artífice intelectual da inflexão conservadora do Partido Trabalhista do Reino Unido, haveria uma dissolução da divisão política iniciada na Revolução Francesa, em virtude da complexidade das relações sociais atingida à época. Esquerda e direta não seriam mais referenciais suficientes para a elaboração de projetos coletivos adequados. Giddens, então, propôs a utilização do que denominou life politics: uma maneira de trabalhar os temas atinentes à justiça social e à eficiência da condução da economia e, concomitantemente, voltar-se ao nível dos problemas cotidianos dos cidadãos.

Em contrapartida, Bobbio (1996) refuta a ideia da falta de adequação dos vocábulos para explicar as contendas da vida contemporânea e se compromete a traçar valores universais para os polos do universo político. Nesse sentido, refere-se à metáfora espacial como um elemento diádico, formado por componentes antitéticos. Por conclusão, enfatiza que o veículo de separação das partes são os entendimentos a respeito da desigualdade. Para os grupos à esquerda, ela deriva de causas artificiais - como os costumes, leis e demais

\footnotetext{
${ }^{7}$ Aqui, cabe ressaltar o interessante trabalho de Segrillo (2004) que ressalta a troca dos signos ideológicos na Rússia, com o fim do projeto soviético. Em um determinado momento da transição, o conservadorismo era associado aos defensores do socialismo e, inversamente, o progressismo relacionado aos partidários da abertura econômica e da virada pró-mercado.
} 
coerções sociais - sendo, assim, socialmente produzida e passível de alteração. Já para a direita, as iniquidades assumem um aspecto natural, ou seja, emanam das capacidades inerentes aos seres humanos e são, por conseguinte, inevitáveis.

A inclinação perante a liberdade, em compensação, marca a oposição de moderados e extremistas - pertencendo tanto à ala progressista, quanto aos conservadores. Enquanto os extremistas empregam métodos autoritários com o propósito de mitigar tendências divergentes, os moderados se abstém dos usos de tais práticas. A interseção dos dois eixos - igualdade e liberdade - daria lugar a um quadrante composto de extrema-esquerda, centro-esquerda, centro-direita e extrema-direita.

A tese de Bobbio, contudo, deixa a desejar se contrastada com os desenvolvimentos mais recentes da teoria política. Isto posto, o ideal de equidade encontra-se presente nas formulações de autores à direita do universo político - caso de Rawls (2005) e sua proposta de "igualdade de oportunidades"; ao mesmo tempo, escritores à esquerda vêm manifestando cada vez mais interesse pela diferença, como propõem as correntes feministas e multiculturalistas (Feres e Pogrebinschi, 2010; Miguel, 2014). A título de exemplo, Nancy Fraser (2003) postula a bidimensionalidade da concepção de justiça, separando as lutas por redistribuição e reconhecimento dos grupos oprimidos. Segundo Fraser, o desmembramento é válido à medida que distintas formas de opressão têm naturezas distintas e, ao vincular os dois conteúdos, reduz-se o escopo dos modos de dominação exercidos pelas categorias dominantes. Assim, no paradigma redistributivo, as injustiças se definem aos moldes das estruturas socioeconômicas; enquanto o paradigma do reconhecimento evidencia as desigualdades com matrizes culturais, fundadas nos padrões de representação, interpretação e comunicação.

Com a nova crise provocada pelo liberalismo econômico em 2008, a academia voltou à carga dos estudos sobre ideologia, com reformulações importantes para a compreensão do contínuo. Atualmente, muitas são as frentes de conhecimento que investem na análise dos construtos ideológicos e sua relevância para o comportamento humano. Dentre elas, vale destacar a o papel dos valores na sedimentação das preferências (Schwartz et al, 2010; Piurko e Davidov, 2011; Kulin e Seymer, 2014; Arikan e Bloom, 2014), os estudos sobre os vínculos entre os processos psicológicos (Oxley et al. 2008; Sibley e Duckitt, 2008; Zumbrunnem e Gangl, 2008; (Jost et al., 2009), a personalidade (Gerber et al., 
2010; Hirsch et al., 2010) e posições políticas; além de trabalhos mais ligados às ciências da natureza - concernentes à neurociência (Amodio et al., 2007; Zamboni et al., 2009; Schreiber et al.,2013; Jost et al., 2014), à genética (Hatemi et al., 2009; Settle et al., 2010) e à patogênese (Fincher et al., 2008; Tybur et al., 2010; Smith et al., 2011) ${ }^{8}$.

Uma das principais novidades oferecidas por essas atualizações reside na noção de multidimensionalidade das crenças políticas, que tenta captar as múltiplas clivagens existentes nas sociedades contemporâneas (Conover e Feldman, 1981; Kerlinger, 1984; Peffley e Hurwitz, 1985; Heath, Evans e Martin, 1994; Evans, Heath e Lalljee, 1996; Ashton et al., 2005; Zumbrunnen e Gangl, 2008; Achterberg e Houtman, 2009; Treier e Hillygus, 2009; Baldassari e Goldberg, 2014; Carmines et al, 2015). A formulação perpassa estudos em países diversos e atravessa tanto os trabalhos de ciência política, quanto os de sociologia e psicologia, e ajuda a compreender de maneira mais matizada o entendimento dos cidadãos comuns acerca das numerosas questões públicas que permeiam os debates societais.

Em vez de uma acepção diádica, tal qual Bobbio (1996), esquerda e direita podem aparecer como conceitos sobrepostos, variando de acordo com os diferentes domínios concernentes aos assuntos coletivos. Em outras palavras, nessa orientação, os indivíduos estão "autorizados"a combinar posicionamentos progressistas e conservadores sobre temáticas heterogêneas, sem seres "acusados"pelos politólogos de baixa sofisticação, inabilidade ou desatenção com os conteúdos propostos por meio dos ditames da política institucional.

Para tanto, faz-se necessário empregar uma medida alternativa à tradicional escala de autoposicionamento ideológico, largamente utilizada pelos especialistas. A espacialidade das preferências, traduzida em fundamento metodológico, remonta às análises da citada Escola de Michigan nos anos 1960. Com efeito, o compósito liberal-conservador começou a ser medido por intermédio de um feeling thermometer, e sua pontuação era baseada em duas indagações nas quais os respondentes tinham de se situar em uma escala de cem pontos, dependendo do grau de afeto (quente ou frio) relativo a cada extremo (Bafumi e Shapiro, 2009).

\footnotetext{
${ }^{8}$ Embora não seja o objetivo da introdução expor exaustivamente os trabalhos recentes sobre ideologia, o leitor interessado pode conferir os principais desdobramentos do campo em Feldman (2013).
} 
Assim, o feeling thermometer tornou-se o precursor da métrica que, a partir da década de 1970, assumiu o posto de parâmetro mais aplicado pelos cientistas políticos para lidar com os componentes ideológicos: a escala de sete pontos. Presente no National Electoral Survey (NES) desde 1972, a adoção de uma medida unidimensional inspirou diversos trabalhos acadêmicos, cujos exames se voltavam aos sistemas de crenças da população em geral.

Considerada um importante preditor para o voto, dada as frequentes e significativas taxas de correlação da variável com as intenções de sufrágio, a escala geralmente mostra-se pouco confiável quando relacionada à identificação partidária e, sobretudo, às inclinações dos indivíduos em relação a issues (Feldman, 1988, 2013; Levitin e Miller, 1979). No Brasil, até então, esta foi soberana nos estudos de comportamento eleitoral, com seguidos reportes de desconhecimento dos termos esquerda e direita pelos cidadãos comuns e de incômodo dos pesquisadores com a mensuração (Rennó e Cabello, 2010; Almeida, 2011; Amaral e Ribeiro, 2015; Oliveira e Turgeon, 2015).

\subsection{Aspectos metodológicos}

Como alternativa, esta tese fundamenta-se em técnicas ligadas à psicometria sobretudo nos modelos de Análise Fatorial (AF), Teoria de Resposta ao Item (TRI), Modelos de Equação Estrutural (MEE) e Análise de Classes Latentes (ACL). De antemão, cabem breves apresentações desse subcampo da psicologia dedicado ao desenvolvimento, à avaliação à aplicação de testes mentais de diversos tipos (Borsboom, 2005). Grosso modo, esses testes procuram mensurar o conhecimento, o comportamento, os traços de personalidade e as habilidades dos indivíduos. Em que pese o desconhecimento acerca das técnicas, as mensurações psicológicas desempenham um papel importante nas ciências humanas, dando substrato à investigação de conceitos - casos do nível de inteligência de homens e mulheres, qualidade de vida, satisfação dos clientes - e de psicopatologias diversas - ansiedade, neuroticismo, dislexia, esquizofrenia, hiperatividade, amnésia, entre outras.

A origem dessa área remonta ao século XIX - notadamente, ao desdobramento 
das pesquisas de Francis Galton $(1822-1911)^{9}$, considerado o pai fundador da disciplina, e ao embate sobre a validade das medidas usadas para comparar diferentes graus de inteligência (Furr, 2007). Interessado no estudo da eugenia, Galton começou a analisar as características humanas - curvatura da cabeça, tamanho dos braços, força física - e sua vinculação com a hereditariedade. Para o cientista, esses atributos incluíam aspectos psicológicos.

A ideia de testes de habilidades simples, fáceis de administrar, funcionou então como propulsora dos modernos exames de inteligência. Na esteira de seu pioneirismo, Karl Pearson, Charles Spearman, Leon Thurstone e Louis Guttman terminaram por sedimentar as bases da metodologia (Poole, 2008), já no século XX ${ }^{10}$.

A psicometria e a ciência política começaram a estreitar seus laços nos interstícios dos anos 1950. McRae (1958), em trabalho seminal, notou a semelhança dos modelos desenvolvidos por Guttman e o contexto da votação parlamentar -, no qual os legisladores estadunidenses, por ocasião dos sufrágios nominais, afirmavam a concordância ou a discordância em matérias de cunho coletivo. O autor, então, utilizou a técnica de análise fatorial, combinada a métodos de escalonamento unidimensional e matrizes de correlação, com a finalidade de revelar os pontos ideias dos representantes à época.

Em razão da baixa capacidade de processamento dos computadores naqueles idos, o modelo só foi operacionalizado por Poole e Rosenthal (1985) na década de 1980 e ficou conhecido na ciência política por NOMINATE. Seu conceito assenta-se na teoria espacial

\footnotetext{
${ }^{9}$ Os mais familiarizados com a estatística devem recordar de outras inovações promovidas por Galton, como a demonstração da utilidade da distribuição normal para descrever características humanas, o desenvolvimento dos coeficientes de correlação e o uso de técnicas de amostragem com o objetivo de identificar e tratar os erros de mensuração (Furr, 2007).

${ }^{10} \mathrm{~A}$ título de curiosidade, Pearson contribuiu com a invenção do coeficiente de correlação - denotado pela letra $r$-, amplamente usado até os dias de hoje nas análises estatísticas, e com a criação de uma técnica que se aproxima dos construtos psicométricos: a Análise de Componentes Principais. Spearman, por seu turno, elaborou outro método importante na área, a Análise Fatorial, com o objetivo de explorar as potencialidades de estudantes ingleses. A matriz de correlação concebida trazia consigo uma inovação fundamental para o campo: a extração de um fator geral (o fator $g$ ), responsável por elucidar as relações entre diferentes variáveis. Thurstone, ao contrapor as conclusões de Spearman, terminou por implementar um desdobramento fundamental da técnica, adequada para lidar com múltiplas dimensões, e Guttman promoveu a análise de escalograma, base dos modernos testes de habilidade (Poole, 2008).
} 
do voto. Segundo esta, os legisladores recebem pontos ideias numa circunscrição abstrata e votam conforme as alternativas políticas mais próximas a estes referenciais.

Não obstante, somente no final dos anos 1990 e início dos anos 2000, com o advento de computadores pessoais mais rápidos e acessíveis, que as técnicas psicométricas começaram a se popularizar na academia norte-americana. Os avanços tecnológicos tornaram possíveis, também, métodos de simulação - especialmente os Métodos de Monte Carlo via Cadeias de Markov (MCMC) - adequados à estimação de complexos modelos multivariados, paulatinamente incorporados à disciplina (Gill e Gainous, 2002; Martin e Quinn, 2002; Jackman, 2000; Clinton et al., 2004).

Atualmente, além do comportamento parlamentar, a psicometria perfila trabalhos com diferentes temáticas - como, por exemplo: a conduta de membros da Suprema Corte (Martin e Quinn, 2002; Bafumi et al., 2005; Peress, 2009); a sofisticação política (Delli Carpini e Keeter, 1997); as preferências dos eleitores (Bafumi e Heron, 2010; Levendusky e Pope, 2010; Stimson, 2004; Ellis e Stimson, 2012); a estrutura dos construtos ideológicos (Conover e Feldman, 1981; Kerlinger, 1984; Peffley e Hurwitz, 1985; Heath, Evans e Martin, 1994; Evans, Heath e Lalljee, 1996; Ashton et al., 2005; Achterberg e Houtman, 2009; Treier e Hillygus, 2009; Baldassari e Goldberg, 2014; Carmines, 2015) e a qualidade das democracias (Treier e Jackman, 2008).

Segundo Borsboom (2005), existem três tipos importantes de paradigmas de mensuração no subcampo: a teoria do teste clássico, o modelo de mensuração representacional e o modelo de variáveis latentes. O primeiro tem como objeto central o escore verdadeiro (true score), relacionado a observações mediante o uso do operador de expectativa. Em outras palavras, a pontuação verdadeira é o valor esperado da pontuação observada. O segundo oferece uma linha de axiomas alicerçada na noção de escala, isto é, na representação matemática de vínculos observáveis entre as pessoas analisadas. Por fim, o mais popular dos modelos, o das variáveis latentes, cuja premissa fundamental repousa na concepção de que os fenômenos psicológicos e sociais podem ter como causa comum fatores não considerados diretamente. Esta tese dedica-se, especialmente, ao terceiro paradigma, em virtude da notoriedade recentemente alcançada nas ciências sociais ${ }^{11}$.

\footnotetext{
${ }^{11}$ Para uma discussão mais detida sobre os três modelos, ver Osburn (2000) e trabalho já citado de Borsboom (2005).
} 
De maneira detalhada, por conseguinte, o modelo em voga assume que fatores latentes podem ser inferidos a partir de manifestações comportamentais distintas. Nesse sentido, a metodologia fornece um grau de abstração que permite a descrição da compatibilidade entre eventos ou regressores, os quais compartilham aspectos similares, ao invés de produzir enunciados restritos de preditores individuais. Assim, por exemplo, uma manifestação psicopatológica como o transtorno de ansiedade - um atributo não verificado de forma explícita - pode ser examinada mediante a investigação de sintomas mais facilmente detectados nos pacientes, a saber: tensão muscular, irritabilidade, fadiga, dificuldade de concentração, medos irracionais, indigestão crônica, insônia, ataques de pânico e/ou comportamento compulsivo. Analogamente, um posicionamento à esquerda seria diagnosticado pela concordância em relação à interferência do Estado na economia, a aceitação da homossexualidade e do aborto, etc.

Em vista disso, o cerne das operações psicométricas reside em técnicas de agregação. Essas, por seu turno, visam minimizar os erros de mensuração contidos nos questionários por motivos variados - como o humor dos respondentes, as condições da entrevista (localização, barulho do ambiente, hora do dia), as características peculiares dos interlocutores (gênero, cor) e o viés provocado por preceitos socialmente desejáveis (Treier e Jackman, 2013) - ou seja, pela necessidade que os inquiridos sentem de manifestar opiniões favoráveis à sua própria apresentação pessoal.

Ademais, teorias a respeito do retorno dos pesquisados a investigações baseadas em surveys mostram que os indivíduos não possuem opiniões pré-formatadas nos níveis de especificidade requeridos pelos questionários. Ao contrário, carregam uma mistura de considerações parcialmente consistentes. Logo, as inclinações informadas muitas vezes não refletem juízos "verdadeiros" acerca dos itens, representando tão somente os pensamentos mais acessíveis na memória no momento da entrevista (Zaller e Feldman, 1992) - aspecto que, por si só, aumenta sobremaneira a probabilidade de inconsistências na mensuração.

A consequência de deixar em segundo plano os erros de mensuração não randômicos é, por conseguinte, a subestimação de preditores individuais nas equações de regressão (Ansolabehere et al., 2008). Por seu turno, com o uso de múltiplos preditores acerca de um mesmo tópico, os pesquisadores autorizam a ponderação dos ruídos nos itens coletados. Além disso, a construção de pontuações mediante a média de variáveis distintas geralmente 
produz cálculos mais robustos das preferências emitidas pelos respondentes.

No entanto, no lugar de simplesmente agregá-las em um índice, somando-as e ponderando-as com base em visões subjetivas sobre sua importância relativa, as abordagens latentes são agnósticas quanto à importância relativa dos preditores. Dessa maneira, ajudam, a um só tempo, a resolver a questão sobre a forma de agregar os indicadores e evitam preferências arbitrárias a respeito de uma suposta adequação dos itens (Treier e Jackman, 2008).

Assim, o processo de mensuração envolve a conceituação da natureza das variáveis latentes e sua definição operacional. Abrange também a decisão sobre a correspondência entre o exame dos preditores observáveis e suas correspondentes localizações num continuum e/ou na classe. Em geral, a escala é o processo que estabelece a correspondência dos dados e os locais dos objetos investigados na variável latente. Uma vez atribuído o local desse posicionamento, compara-se os casos estudados.

Essa concepção guarda similitude com a teoria convencional de estimação dos parâmetros. Enquanto as técnicas psicométricas usam valores de y para a compreensão de quantidades não observáveis presentes em $\xi_{i}$, a estimação dos parâmetros serve-se dos dados observáveis y para fazer inferências acerca dos valores desconhecidos em $\Theta$. Isto é, a despeito de uma mudança na nomenclatura, a questão relativa à estimação mantém a mesma caraterística. Formalmente, em termos bastante sumários, os modelos podem ser expressos da seguinte maneira:

$$
X_{i}=\xi_{i}+\delta_{i}
$$

Em que $\delta_{i}$ representa o erro de mensuração, e $i$ indexa as unidades observacionais. As propriedades de $\delta_{i}$, como a média ou a variância, acusam a adequação do modelo quanto à validade ou à confiabilidade - tal qual demonstrado na seção subsequente. A contemplação dos termos de erro cumpre a tarefa de reduzir as inconsistências dos questionários survey acima descritas. Logo, em certas situações, os traços subjacentes $\xi_{i}$ podem conservar alguma estabilidade ainda que a resposta de um determinado respondente a itens individuais $X_{i}$ apresente alterações perceptíveis, conquanto o erro de mensuração $\delta_{i}$ contabiliza a variação. 
A ideia subjacente aos modelos com variáveis latentes é que, embora não possam ser testados diretamente por regressores individuais, estes afiançam a análise de suas implicações para a distribuição de probabilidade acerca de um número limitado de itens.

A representação gráfica mais comum desses modelos encontra-se disposta na figura 1. Onde aparecem as especificações relativas aos padrões de covariância, revelando que as relações entre os indicadores são explicadas mediante uma regressão na variável latente (Bagozzi e Edwards, 2000). Os construtos não manifestos $\xi_{i}$, por convenção, são exibidos em formatos circulares, as variáveis manifestas $X_{i}$ com configurações retangulares, os eixos demarcam a ligação dos componentes da equação e a associação com os termos de erro $\delta_{i}$.

Figura 1: Representação gráfica convencional das técnicas com variáveis latentes

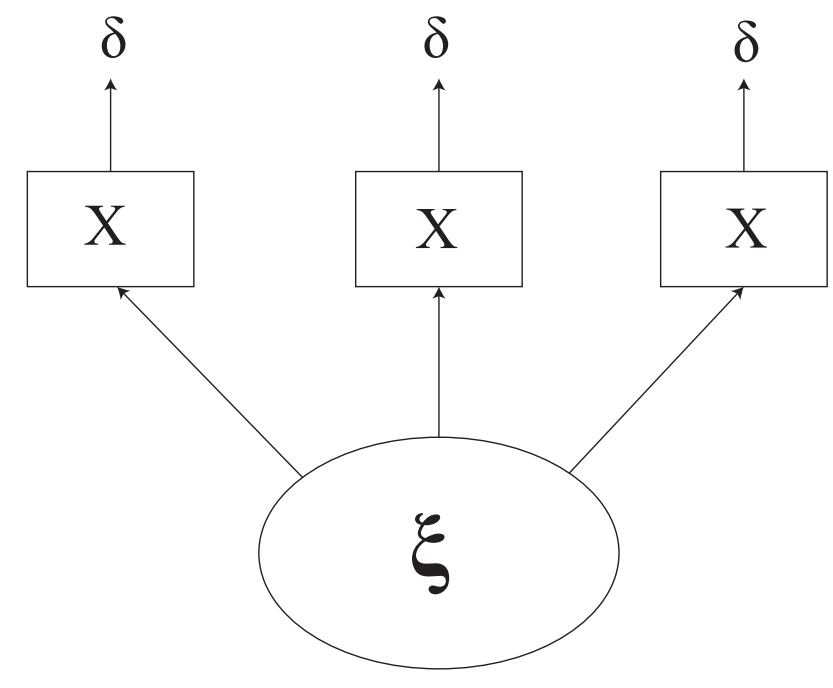

\subsection{Objetivos e estrutura da tese}

Para dar conta dos postulados teóricos e metodológicos desenvolvidos até aqui, esta tese divide-se em três capítulos. Não obstante, as seções podem ser lidas separadamente, dado que as divisões contemplam os principais argumentos expostos pela literatura no corpo de cada repartição, antes da apresentação dos postulados defendidos. Os dados avaliados remetem a uma série distinta de bancos, compostos pelo World Values Survey, Datafolha (edição Cultura Política), Estudos Eleitorais Brasileiros (ESEB) e Latin 
American Public Opinion Project (LAPOP). Dessa forma, procurou-se ponderar possíveis alterações nos sentidos atribuídos e nos usos ideológicos ao longo das décadas investigadas.

O trabalho, portanto, estrutura-se em torno de uma tríade composta de períodos distintos, porém interligados, conforme uma ordenação definida pela dinâmica das investigações pretéritas acerca do tema da ideologia. Assim, temos como objeto de análise os entendimentos dos brasileiros sobre os conceitos esquerda e direita; os motivos para a falta de compreensão a respeito dos termos; a postulação de uma mensuração alternativa, com o objetivo de captar a maneira como os cidadãos concebem as clivagens políticas; e, por fim, o uso que estes fazem dos sistemas de crenças no sentindo de guiar o comportamento político.

Seguindo esse movimento, o primeiro capítulo explora a compreensão dos indivíduos a respeito da questão da ideologia e exibe os diagnósticos oferecidos pelos pesquisadores do tema. São analisados, por conseguinte, diferentes componentes da identificação com ambos os lados do espectro político. Nessa parte, destaca-se que o pertencimento a um dos signos se recobre de aspectos valorativos e, sobretudo, simbólicos. A estima pela ordem é a valor que melhor afasta os declarados direitistas dos esquerdistas - e não a condução da economia ou as inclinações que tangem aos costumes sociais. No entanto, o preditor mostra-se menos importante que referenciais simbólicos, ligados à afeição por grupos sociais particulares e/ou legendas partidárias. Ademais, constata-se um elevado grau de variação e de incompreensão dos termos.

Tendo isso em vista, o capítulo dois averigua as razões do incômodo dos brasileiros com os vocábulos, mediante formulações que distinguem as vertentes simbólicas e operacionais da ideologia. Ao contrário das indicações publicadas em outros trabalhos habituados a explicações puramente institucionais ou a faculdades individuais -, atribui-se esse desconforto a fatores ligados às transformações das estruturas sociais. O aumento recente das clivagens sociais produziu um quadro multidimensional no qual preceitos progressistas e conservadores podem se misturar e configurar novos grupamentos ideológicos.

O comportamento político desses grupos, portanto, é o assunto do capítulo três. Nesse espaço, discute-se a premência de uma apreciação mais acertada da ordenação das crenças coletivas e, como exemplo, evidencia-se a importância de concepções ideológicas, convencionais e alternativas, e seu impacto como preditor do voto em pleitos distintos - 
da abertura política, passando pelo alinhamento de 2006, às eleições de 2014. Em todas, constata-se a resiliência dos sistemas de crenças como balizador do sufrágio.

Nas considerações finais, retomam-se algumas questões que orientaram a realização desta pesquisa, com a avaliação das principais ideias e das prováveis contribuições do estudo aqui apresentado. 


\title{
2. Aspectos simbólico-afetivos da identifica- ção ideológica
}

\author{
What do I think? Well, I think Howard Dean ${ }^{12}$ should \\ take his tax-hiking, government spending, latte-drinking, \\ sushi-eating, Volvo-driving, New York Times-reading, \\ body-piercing, Hollywood-loving left wing freak show \\ back to Vermont where it belongs. \\ - Comercial de televisão idealizado pelo Club for Growth $^{13}$.
}

Logo nos primeiros anos do século XX, Graham Wallas escreveu o primeiro trabalho de um campo que viria ser conhecido pela alcunha de psicologia política (Jost e Sidanius, 2004). Em Human Nature in Politics (1908), o autor atentou para a dificuldade em distinguir entre inferências racionais e não-racionais no fluxo da experiência mental, enfatizando que muitos dos processos semi-conscientes pelos quais os indivíduos formam suas opiniões políticas não figuram no universo do intelecto. As ideologias políticas são bons exemplos dessa formulação, conforme será demonstrado ao longo deste capítulo.

Segundo Jost et al (2013), as ideologias muitas vezes servem a funções psicológicosociais, que podem ou não ser inteiramente racionais e, em alguns casos, ajudam a explicar por que as pessoas são atraídas a certos ideários. Assim, propõe uma dupla dinâmica para esses construtos: uma superestrutura discursiva e uma subestrutura funcional (ou motivacional). A primeira descreve um conjunto de atitudes socialmente construída - como valores e crenças ligados a um posicionamento específico em determinado momento e lugar. Esta seria uma representação social que orienta o julgamento de aspectos coletivos e normalmente é transmitida pelas elites políticas para os cidadãos comuns. A segunda contempla uma constelação de necessidades sociais e psicológicas que impulsionam as preferências políticas. Esta seção, e a tese como um todo, se ocupam da dinâmica superestrutural.

Nesse sentido, a pertinência desse processo remonta a uma literatura que, usual-

\footnotetext{
${ }^{12}$ Howard Dean é um político progressista do Partido Democrata dos Estados Unidos. Foi presidente do comitê do partido e governador do Estado de Vermont, distrito nacionalmente famoso pelo posicionamento à esquerda de seus eleitores.

${ }^{13} \mathrm{O}$ Club for Growth é um grupo sem fins lucrativos estadunidense que tem por objetivo pressionar os legisladores a votar em leis pró-mercado.
} 
mente, confere aos rótulos ideológicos a atribuição de heurísticas, ou melhor, de atalhos cognitivos cuja função é auxiliar os indivíduos a entender o complexo mundo da política (Brady e Sniderman, 1985; Sniderman, Brody e Tetlock, 1991). Assim, o eixo opera aos moldes de um dispositivo ao qual partidos e representantes são classificados, bem como um código comunicativo entre políticos, a mídia e os cidadãos comuns (Fuchs e Klingemann, 1990). Todavia, os significados desses dísticos variam conforme os cidadãos e os países (Inglehart e Klingeman, 1976; Zechmeister e Corral, 2010). Por certo, o maior desafio dessas investigações é justamente o de analisar as acepções atribuídas aos termos esquerda e direita por diferentes grupos sociais.

Na literatura nacional poucos trabalhos se debruçaram de maneira profunda sobre o assunto. Aqueles que o fizeram atestaram a dificuldade dos brasileiros em lidar com essas categorias. Assim, houve os que apostassem em signos valorativos, outros em aspectos contextuais e um terceiro grupamento incrédulo da capacidade de distinção do contínuo por parte dos eleitores (Bonifácio et al., 2014; Oliveira e Turgeon, 2015, Zechmeiester, 2015). Dentre os mais otimistas, nos preceitos ligados aos valores, a defesa da ordem ganhou destaque quando cotejada a elementos econômicos ou sociais (Singer, 1999, 2012; Ames e Smith, 2010). Analogamente, as circunstâncias históricas, especialmente o posicionamento em relação ao regime militar, ocuparam espaço relevante na análise da diferenciação dos vocábulos esquerda e direita (Carreirão, 2002, 2009; Telles e Storni, 2010).

Acompanhando esses passos, o presente capítulo dedica-se à tradicional medida de autoposicionamento ideológico, com o objetivo de examinar os perfis sociais tipicamente associados a uma compreensão unidimensional do universo político e os significados conferidos aos vocábulos. Desta vez, no entanto, opta-se por investigar detidamente o sentido dos conceitos em perspectiva histórica, mediante bases de dados coletadas em períodos distintos. Afora o caráter longitudinal, a análise dá maior atenção à possibilidade de modelos heurísticos diferenciados, pautados nas características dos embates políticos nacionais, em cenários valorativos e, sobretudo, simbólicos-afetivos.

Com efeito, o postulado fundamental das linhas subsequentes considera a ideia de que os indivíduos podem associar noções heterogêneas a um mesmo conceito. Isso porque as concepções mais abstratas do jogo político não raro conduzem a entendimentos 
peculiares de temas idênticos. Para desenvolver os pontos expostos até aqui, combinamse técnicas adequadas para lidar com variáveis latentes e observáveis, em que pese o predomínio das regressões convencionais. O foco do estudo tem nas bases de dados do World Values Survey (WVS) o condutor empírico principal, a fim de guiar a apreensão das definições facultadas à ideologia. Todavia, bancos alternativos como o Datafolha e Perseu Abramo (edição Cultura Política), Latino Barômetro, Barômetro das Américas e Estudo Eleitoral Brasileiro ajudam a compor os exames do posicionamento ideológico.

O capítulo, para melhor compreensão, divide-se em quatro seções. Na primeira, apresenta-se uma discussão teórica acerca dos principais componentes da localização ideológica. Na segunda, são exibidos os perfis e os padrões de vinculação do eleitorado nacional com as categorias em pauta. Em seguida, um exame dos valores e dos elementos afetivos característicos dessa compreensão com o contínuo esquerda-direita. Nos comentários finais, constam o resumo dos itens levantados e reflexões sobre o enredo empregado.

\subsection{O desconhecimento semântico das categorias}

De início, cumpre ressaltar que a controvérsia em torno dos significados atribuídos às categorias não se restringe ao Brasil. A trajetória dos desacordos remete à formulação inicial criada por Angus Campbell e companhia no livro The American Voter (1966), obra central da Escola de Michigan, cujo mote consistia em indagar até que ponto os estadunidenses se mostravam competentes para compreender os debates públicos e agir politicamente. Para tal, concentraram esforços no conceito de ideologia política, definido como um conjunto de crenças interconectadas e estáveis, representativas das visões de mundo dos indivíduos.

Com esta intenção, os autores, munidos de entrevistas baseadas em surveys, pediam aos entrevistados um posicionamento em relação a questões políticas (issues) e sua respectiva localização em uma escala, ordenada tal qual um contínuo, das categorias "extremamente liberal" a "extremamente conservador" que, nos Estados Unidos, são correlatos dos qualificativos esquerda e direita. Assim, uma tipologia foi concebida de acordo com o "grau de conceituação" dos respondentes. Eis que a tabulação apontava para uma amostra com pouco mais de $10 \%$ dos eleitores descritos como ideológicos, isto é, 
capazes de associar suas preferências à identificação referida. Diante das descobertas, não havia margem a dúvidas: a ideologia não seria um fator decisivo para a deliberação do voto. Os pesquisadores sugeriam, pois, que o motor do comportamento político tinha na identificação partidária - a vinculação psicológica dos eleitores a um determinado partido, construída mediante o processo de socialização - a sua engrenagem principal.

Anos mais tarde, Converse, um dos coautores de The American Voter, reforçou os achados anteriores, mas indicou um nexo entre a estruturação do sistema de crenças e o nível educacional dos indivíduos. Nesse sentido, Converse fazia uso da categoria constrição (constraint), projetada como um amálgama capaz de ligar as diferentes opiniões do eleitorado. Somente os mais escolarizados, no entanto, conseguiam relacionar suas ideias e atitudes, ao passo que a maioria da população mantinha um sistema de crenças ilógico. De maneira análoga, a habilidade de pensar ideologicamente - isto é, de distinguir os diferentes partidos e candidatos nos marcos de um contínuo liberal-conservador - estaria enredada com a sofisticação dos cidadãos. Para piorar, as inclinações do público apresentavam pouca estabilidade ao longo do tempo, parecendo que os indivíduos adotavam certos posicionamentos de modo randômico.

Os trabalhos de Michigan levaram a um intenso embate na academia norte-americana sobre a quantidade de eleitores ideológicos no país. Nas décadas seguintes, três teorias alternativas emergiram para desafiar os postulados desenvolvidos até então. De forma breve, a primeira reflete o contexto histórico ao qual as obras estavam imersas, sem grandes conflitos identitários ou polarização política (Nie et al., 1976; Abramowitz, 2010); a segunda repousa no conteúdo normativo das inferências referidas, com base em um modelo de estruturação ideal das crenças, desconsiderando o formato como as pessoas efetivamente interpretam o jogo político (Lane, 1962); e, por fim, críticas de caráter metodológico expõem as imperfeições associadas à confiabilidade dos itens presentes nos questionários survey (Ansolabehere et al., 2008). Todavia, conquanto minimizem os contornos negativos, as teorias elencadas não apagam a rubrica fundamental: a maioria da população mostra-se confusa com os conceitos liberal e conservative.

Pois é envolta por esses entreveros que as primeiras investigações empíricas acerca dos vocábulos esquerda e direita chegaram ao Brasil, especialmente no início dos anos 1990. Afinal, os brasileiros seriam capazes de usar essas categorias? Além disso, qual 
conteúdo atribuem aos termos em questão?

Embora outros trabalhos retratem o fenômeno e sua importância para a fundamentação do voto (Mettenheim, 1995), as identificações ideológicas ganharam destaque na literatura nacional com as obras de André Singer (1999, 2012). O autor, ao recorrer a dados de pesquisas de opinião, mostra que a maior parte dos entrevistados consegue se localizar na escala unidimensional. As altas taxas de autoposionamento sustentam os argumentos e evidenciam um aumento na capacidade dos eleitores de manipular os vocábulos. Singer, contudo, realça a falta de um uso cognitivamente estruturado das categorias, já que cerca de $60 \%$ dos respondentes não sabiam dizer o significado correto de $\operatorname{ambas}^{14}$.

Em vista desse paradoxo, da localização individual no contínuo e, ao mesmo tempo, desconhecimento da natureza semântica dos itens, o autor toma de empréstimo uma ideia desenvolvida fora do país naqueles anos para reforçar a importância da variável em questão, a saber: a concepção de uma orientação difusa. Em suas palavras:

Observe-se que reconhecimento não quer dizer a utilização dessas categorias de uma maneira cognitivamente estruturada, assim como não significa que, se perguntado o que o levou a votar nesse ou naquele candidato, o eleitor espontaneamente mencionaria as categorias esquerda ou direita como justificativa do voto. Reconhecimento quer dizer apenas que, quando é apresentada ao eleitor uma escala formada a partir dessas categorias, ele sabe, ainda que intuitivamente, do que se trata (Singer, 1999: 131).

Do ponto de vista teórico, a definição proposta coaduna-se ao aparato conceitual elaborado por Sartori (1979), partindo da noção de voto por imagem. Aqui, pressupõe-se o entendimento de ideologia em seu sentido fraco, e não como um pensamento logicamente estruturado. Portanto, a adesão a uma das bandeiras justifica uma compreensão intuitiva, sinaliza uma orientação política geral do eleitor, que não requer alta sofisticação dos

\footnotetext{
${ }^{14} \mathrm{O}$ mesmo problema pode ser observado em obra anterior, de Von Mettenheim. Em The Brazilian Voter (1995), o autor também retira da análise os missing values - opção que elimina mais da metade dos entrevistados que não sabiam se posicionar na escala esquerda-direita e que, obviamente, termina por enviesar os resultados.
} 
cidadãos. Resumindo, mesmo sem saber ao certo verbalizar cada uma das tendências, os indivíduos são capazes de se guiar por esses postulados de maneira difusa.

Dada a importância da variável, Singer insiste no conteúdo substantivo dessas expressões para os eleitores em geral:

Não é a igualdade em si, porém o modo de atingir a igualdade, que divide o eleitorado entre esquerda e direita. Enquanto a localização à direita está associada à ideia de reforço da autoridade do Estado para promover as mudanças igualitárias, de modo que elas ocorram sem prejuízo da ordem, a localização à esquerda está vinculada a uma contestação da autoridade do Estado na sua função repressiva em relação aos movimentos sociais que visam a produzir transformações na direção da igualdade. (Singer, 1999: 20)

O livro Os Sentidos do Lulismo (2012), do mesmo autor, termina por ratificar os preceitos expostos quando afiança o ajuste ideológico do ex-presidente Lula (Partido dos Trabalhadores) às ambições perenes de um estrato decisivo do eleitorado nacional, o subproletariado, que encontrou na liderança petista - domesticada com o passar dos anos - um articulador ideal para seus desígnios ${ }^{15}$.

Como foi dito, a medida unidimensional, baseada nos trabalhos citados, passou a permear os estudos de comportamento eleitoral, com críticas e metodologias variadas sobre suas possíveis interpretações. Começando por Carreirão (2002), Singer superestima o peso da identificação ideológica diante de outras variáveis e "não se preocupa em verificar se há distinções entre o eleitorado (por exemplo, segundo seu grau de escolaridade) (Carreirão, 2002: 32)". Consequentemente, o autor explora a relação entre os níveis de instrução e a capacidade de conceituação dos termos esquerda e direita. Os achados, que acompanham a maioria dos diagnósticos presentes na literatura internacional, conforme demonstrado anteriormente, dão ênfase à conexão entre o grau de escolaridade e a compreensão mais

\footnotetext{
${ }^{15}$ Sobre o arranjo ideológico, Rennó e Cabello (2010) discordam de Singer e afirmam que "os lulistas não representam um novo realinhamento político-ideológico, com base em classe e ideologia, como argumenta Singer". (2010: 40). São, sim, eleitores não-alinhados que votam baseados em suas avaliações retrospectivas do desempenho do governo, sem maiores inclinações ideológicas. Por outro lado, Silva e Rennó (2015) fazem uma crítica à noção minimalista de realinhamento usada pelo autor.
} 
acertada dessa dualidade.

Explorando as categorias a partir de perguntas semiabertas, com dados do início dos anos 1990, o autor constatou que o significado mais atribuído aos dísticos se relacionava à predileção com o governo incumbente (tabela 1). "Ser contra"ou "ser governo" eram os elementos determinantes da ideologia para algo em torno de $20 \%$ e $30 \%$ do eleitorado nacional. A segunda opção preferida pelos respondentes tinha no julgamento moral sua base: a esquerda associada ao "errado/ negativo", a direita, ao "certo/melhor". Para a vasta maioria da população, entretanto, parece que as categorias eram simplesmente abstratas demais, dado os elevados índices de não respostas.

Conquanto não existam fundamentos empíricos para inferências do tipo, suspeitase que no período da abertura democrática, o contexto tenha a ver com a dificuldade de avaliação dos conceitos pela população em geral: à época, eram considerados de "esquerda" os opositores à ditadura civil-militar. Analogamente, as atribuições maniqueístas dos vocábulos podem ser fruto do esforço do regime autoritário no sentido de vincular a imagem dos antagonistas a rótulos pejorativos.

Os diagnósticos de Ames e Smith (2010) seguem a mesma tendência: "ainda que as taxas de identificação ideológica sejam moderadamente altas, e maiores do que o índice de identificação partidária, os brasileiros que se localizam nesse contínuo não têm uma consciência clara do conteúdo ideológico por trás dos rótulos" (tradução livre) (Ames e Smith, 2010: 29). Com uma técnica diferente de coleta de dados - as entrevistas de painel -, os autores mantêm as descobertas de Carreirão ao enfocar a associação positiva entre o aumento da escolaridade e o autoposicionamento no espectro. Terminam por declarar que o "esquerdismo" (leftism) é fortemente afetado pelo apoio ao ex-presidente Lula, à tolerância à desordem social, a condutas pró-democracia e à oposição ao regime militar. De forma contrastante, atitudes em favor do livre comércio não tiveram um impacto significativo no contínuo.

Na esteira dos apontamentos de Inglehart (2007), Tarouco e Madeira (2013) levantam a possibilidade de os eleitores mais jovens terem menor capacidade de utilizar os vocábulos. Essa dificuldade explica-se por conta de uma aparente substituição de valores materialistas por preceitos pós-materialistas nas gerações nascidas no pós-guerra. Assim, a segurança material alcançada no período teria reduzido as ânsias redistributivas em 
Tabela 1: Perguntas semiabertas sobre o entendimento dos vocábulos

\begin{tabular}{|c|c|c|c|}
\hline \multicolumn{4}{|c|}{ Painel A : Datafolha $1989(\mathrm{~N}=2083)$} \\
\hline \multicolumn{2}{|l|}{ O que é ser de esquerda? } & \multicolumn{2}{|l|}{ O que é ser de direita? } \\
\hline Respostas & Frequência & Respostas & Frequência \\
\hline Não sabe/não respondeu & $43 \%$ & Não sabe/não respondeu & $42 \%$ \\
\hline Estar contra governo/status quo & $19 \%$ & Ser ou apoiar o governo & $19 \%$ \\
\hline O errado/negativo & $10 \%$ & Estar certo/o melhor & $11 \%$ \\
\hline Comunismo/marxismo/socialismo & $8 \%$ & Defender interesses elites/empresários & $5 \%$ \\
\hline Defender interesses povo/maioria & $4 \%$ & São os poderosos/os que tem poder & $4 \%$ \\
\hline Falta de liberadade econômica & $3 \%$ & Outras respostas & $19 \%$ \\
\hline Outras respostas & $13 \%$ & & \\
\hline \multicolumn{4}{|c|}{ Painel B : Datafolha $1993(\mathrm{~N}=2500)$} \\
\hline \multicolumn{2}{|l|}{ O que é ser de esquerda? } & \multicolumn{2}{|l|}{ O que é ser de direita? } \\
\hline Resposta & Frequência & Resposta & Frequência \\
\hline Não sabe/não respondeu & $47 \%$ & Não sabe/não respondeu & $47 \%$ \\
\hline Estar contra o governo/status quo & $20 \%$ & Ser ou apoiar o governo & $20 \%$ \\
\hline Defender interesse do povo/maioria & $8 \%$ & Estar certo/melhor & $6 \%$ \\
\hline Comunismo/socialismo & $4 \%$ & Defender interesse do povo/maioria & $4 \%$ \\
\hline O errado/negativo & $3 \%$ & Defender interesse elites/empresários & $4 \%$ \\
\hline Não tem diferença & $3 \%$ & Não tem diferença & $3 \%$ \\
\hline Outras respostas & $15 \%$ & Outras respostas & $17 \%$ \\
\hline \multicolumn{4}{|c|}{ Painel C : Fundação Perseu Abramo $1997(\mathrm{~N}=4935)$} \\
\hline \multicolumn{2}{|l|}{ O que é ser de esquerda? } & \multicolumn{2}{|l|}{ O que é ser de direita? } \\
\hline Resposta & Frequência & Resposta & Frequência \\
\hline Não sabe/não respondeu & $36 \%$ & Não sabe/não respondeu & $34 \%$ \\
\hline Estar contra o governo/status quo & $28 \%$ & Ser ou apoiar o governo & $30 \%$ \\
\hline Coisas negativas & $9 \%$ & Estar certo/melhor & $11 \%$ \\
\hline Contra alguma coisa/contra tudo/ só criticam & $5 \%$ & Defender interesse elites/empresários & $3 \%$ \\
\hline Defender interesse do povo/maioria & $4 \%$ & Outras respostas & $22 \%$ \\
\hline Fazer manifestações/greves/ser radical & $3 \%$ & & \\
\hline Outras respostas & $15 \%$ & & \\
\hline
\end{tabular}

troca de motivações que não se encaixam exatamente na metáfora espacial.

Em artigos mais recentes, Bonifácio et al. (2014) e Oliveira e Turgeon (2015) apresentam diagnósticos ainda mais pessimistas. No primeiro, um atestado de baixas taxas de correlação de variáveis usualmente associadas com o espectro esquerda-direita: "a distribuição muito próxima de direitistas e esquerdistas em questões sobre intervenção estatal na economia e igualdade entre os homens nos faz considerá-las insuficientes para medir adequadamente a ideologia dentre o eleitorado brasileiro" (Bonifácio et al., 2014: 
305). No segundo, os resultados do exame apontam "um completo distanciamento do autoposicionamento ideológico do eleitorado e suas preferências políticas", mesmo entre os eleitores mais sofisticados (Oliveira e Turgeon, 2015: 576). Em ambos, um receituário que sugere a operacionalização de um método mais acurado para compreendermos a estruturação das crenças políticas dos cidadãos.

\subsubsection{Outros componentes da identificação ideológica}

Em maior ou menor medida, portanto, a literatura nacional tem sublinhado a inexistência de um vínculo claro entre o posicionamento ideológico e questões do universo político. Entretanto, esta lacuna deve-se em parte à possibilidade da compreensão semântica dos termos "esquerda" e "direita" estar associada a conteúdos simbólicos. Isso porque uma quantidade significativa de trabalhos revela que a ideologia dos cidadãos não é determinada essencialmente por valores individuais (Inglehart e Klingemann, 1976; Klingemann, 1979; Conover e Feldman, 1981; Freire, 2006, 2008). Nesse sentido, para Conover e Feldman (1981), o significado atribuído a essas categorias segue também uma orientação simbólico-afetiva, cujo substrato repousa na capacidade dessas insígnias produzirem sentimentos positivos ou negativos. Não à toa, como citado anteriormente, ao analisar os questionários com perguntas semibertas, Carreirão (2002) e Almeida (2011) encontraram grandes correlações dos vocábulos em pauta com julgamentos morais sobre o que é "certo" ou "errado".

Em vista disso, na ausência de ancoramentos valorativos, a substância dos rótulos ideológicos pode ser derivada de outros símbolos relacionados, com avaliações próprias, influenciados por predisposições de longa data. Para exemplificar a forma como as orientações afetivas contaminam a localização no contínuo esquerda-direita, pode-se citar a propensão dos parlamentares brasileiros se declararem mais à esquerda de onde realmente estão. O fenômeno, nomeado por Rodrigues (1987) e Zucco (2011) como a "direita envergonhada", enfatiza o suposto desconforto dos legisladores com um dístico antes relacionado à ditadura civil-militar. Consequentemente, o nexo do período autoritário com o rótulo "direita" enseja uma reação negativa e, por conseguinte, a preocupação da classe política em se ver atrelada ao conceito. 
Desse modo, os emblemas políticos pertencem a diferentes matrizes, como as normas estabelecidas pelo jogo de poder, as instituições formais, os laços fomentados pelas elites políticas e a afinidade entre atores não governamentais e pautas específicas. Esses signos desempenham papéis distintos na sociedade; ora servindo de base para a solidariedade social, ora assumindo contornos de diferenciação e de conflitos coletivos (Connover e Feldman, 1981). À medida que os referentes ideológicos atuam conforme a lógica disruptiva, na falta de alusões cognitivamente estruturadas, espera-se que a identificação com algum dos lados da metáfora espacial esteja subordinada a outras representações das disputas sociais, tal qual a noção de pertencimento a determinados grupos.

Desde o artigo seminal de Inglehart e Klingemann (1976), o posicionamento ideológico tem sido vinculado a três componentes principais: 1) os valores individuais, 2) a estrutura social e a 3) identificação partidária. O primeiro reporta ao âmbito dos preceitos discutidos acima, no qual o fundamento primário se sustenta na predileção das pessoas por crenças políticas distintas. O segundo, à percepção de um lugar objetivo das pessoas na sociedade ou à associação subjetiva com certos grupamentos societais como condutorchefe da ideologia. Por último, o terceiro componente destaca a importância das lealdades partidárias nessa predisposição.

Vale dizer que, de acordo com os dois últimos tópicos, os indivíduos podem reconhecer e usar rótulos ideológicos em conexão com partidos ou grupos sociais sem saber ou considerar as implicações desses conceitos para suas próprias posições políticas. Essas lealdades são capazes, pois, de produzir desacertos entre a ideologia mencionada e as preferências sobre os temas mobilizados no debate público.

Os achados desse tipo de literatura, por certo, não são homogêneos, mas compartilham alguns elementos comuns. Em geral, existe um relativo otimismo com o aumento da relevância dos valores nas preferências eleitorais, notadamente entre os cidadãos mais escolarizados (Levitin e Miller, 1979; Inglehart, 1984; Ansolabehere, 2008; Baker e Greene, 2015). Em relação aos grupos sociais, predomina o diagnóstico de que o impacto das condições objetivas de classe vem erodindo com o passar dos anos, enquanto verificamos o aumento do peso das identidades grupais subjetivas (Inglehart e Klingemann, 1976) ${ }^{16}$.

\footnotetext{
${ }^{16}$ Nesse sentido, cumpre destacar o contraditório: Freire (2006) opõe-se aos achados de Inglehart e Klingemann (1976) ao enfatizar que os fatores sociais voltaram a ser importantes preditores da identificação
} 
Em outras palavras, as classes baixas, baluarte do pertencimento com a esquerda, cedem espaço a enfrentamentos conduzidos por grupos da então denominada "nova política": os movimentos ambientais, feministas, negro, LGBTT, etc.

Por fim, as lealdades partidárias figuram como a engrenagem central, fornecendo "colas"simples e concretas, em especial em sistemas partidários com altos índices de polarização, facilitando a compreensão das pessoas com os abstratos conceitos espaciais (Inglehart e Klingemann, 1976; Kinder, 1998; Krosnick, 2010; Freire e Kivistik, 2013).

Tendo em vista a bibliografia exposta, cabe delinear os eixos dos questionamentos: em que medida os brasileiros se posicionam no contínuo ideológico? Existem diferenças de perfis associados a essa vinculação? Se os significados costumam se alterar conforme o contexto social e histórico, quais acepções são mais frequentemente atribuídas aos conceitos?

\subsection{A escala de autoposicionamento ideológico e os perfis associados}

Em virtude da discussão acerca do posicionamento ideológico, o objetivo desta seção é avançar no tema com uma análise longitudinal, agregando os dados e dispondo-os em uma conjuntura temporal ampliada. Os cientistas políticos usualmente têm solicitado aos respondentes que se localizem em um contínuo esquerda-direita, com a finalidade de caracterizar as preferências ideológicas dos cidadãos. Tipicamente, a pergunta apresentase com a seguinte configuração:

- "Como você sabe, muita gente quando pensa em política, utiliza os termos esquerda e direita. No quadro que aparece neste cartão, em qual posição você se colocaria, sendo que a posição 'um' é o máximo à esquerda e 'sete' é o máximo à direita?" (Cultura Política, Datafolha, 1989) ${ }^{17}$.

O gráfico 1 oferece algumas tendências do posicionamento dos brasileiros. A dispo-

ideológica, principalmente entre as gerações mais jovens na Europa.

${ }^{17} \mathrm{O}$ enunciado e os pontos da escala podem mudar ligeiramente conforme os institutos de pesquisa - o que causa viés na localização dos respondentes. Todas as perguntas usadas para montar o gráfico estão dispostas no apêndice. 
sição dos dados acompanha a trajetória da abertura política e os principais fatos recentes da política nacional. No início da década de 1990, o Brasil e a América Latina enfrentavam os efeitos daquilo que se convencionou chamar de "Consenso de Washington", marco do aprofundamento do neoliberalismo na região (Luna e Kaltwasser, 2014). O Brasil de então, capitaneado por Fernando Collor, membro de um desconhecido Partido da Renovação Nacional (PRN), se abria à moda do momento, afinando um concerto que tentava harmonizar a privatização de serviços públicos e a abertura do mercado interno ao controle da hiperinflação e da redução da dívida pública. O impedimento do presidente, em 1992, não trouxe grandes alterações no ideário do modelo econômico a ser seguido. A inflação, controlada durante o governo Itamar Franco (PMDB), deu força à candidatura de seu Ministro da Fazenda, Fernando Henrique Cardoso (PSDB) (Mendes e Venturi, 1994).

Figura 2: Série histórica da escala de autoposicionamento ideológico

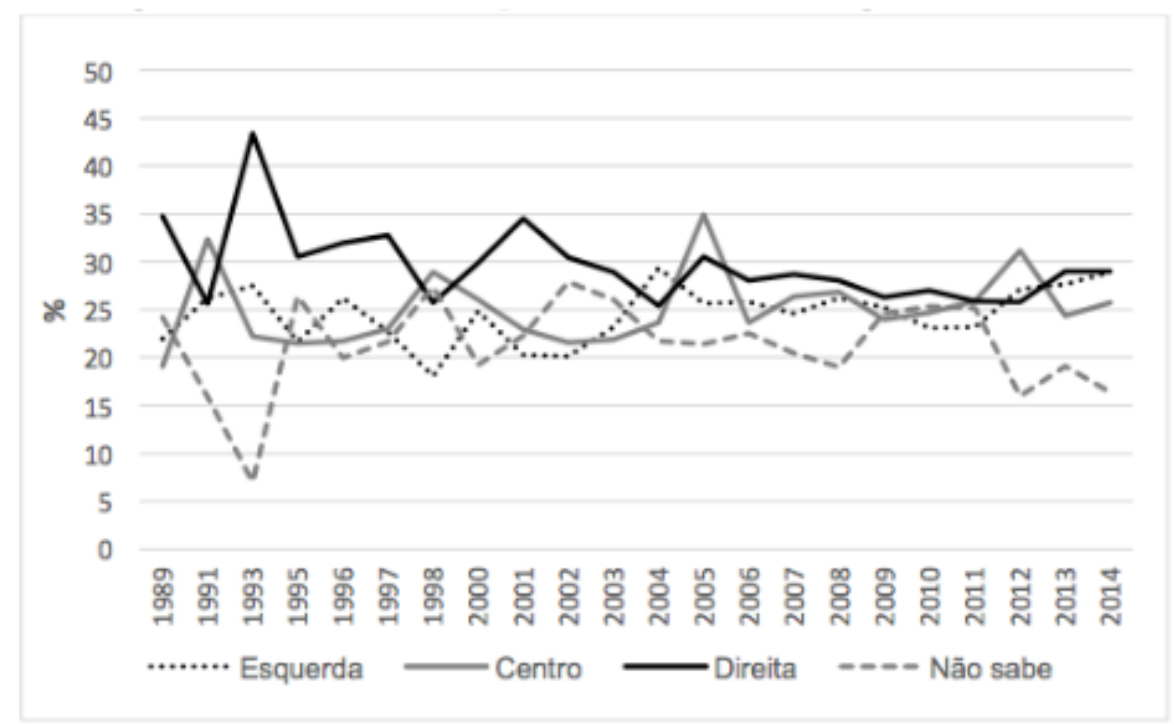

Nota: Gráfico estimado com dados do Datafolha, Fundação Perseu Abramo, Latino Barômetro, LAPOP, ESEB e World Values Survey.

Os efeitos deletérios do segundo mandato de FHC, envolto em baixos índices de cresci- mento e altas taxas de desemprego, impediram o ex-presidente de formar seu sucessor, José Serra (PSDB), à época. De 2002 a 2014, o PT governou o país envolto a sucessivos escândalos de corrupção, que culminaram no discutível impedimento da presidente Dilma Roussef em 2016. Os acontecimentos relatados, no entanto, não produziram 
inflexões significativas nos níveis de identificação ideológica.

Senão vejamos: a proporção dos que "não sabem/não responderam" sempre foi minoria ao longo das décadas - oscilando entre 7\%, em 1993, e 27\%, em 2002. Essa parcela vem caindo na última década, mas ainda apresenta um patamar relevante, algo entre $15 \%$ e 20\%. Fato que contempla uma preocupação de Carreirão (2008): para o autor, com a formação heterogênea de uma perspectiva partidária e ideológica das chapas presidenciais comandadas pelo PT a partir de 2002, as diferenças entre esquerda e direita podiam ser diluídas do ponto de vista dos cidadãos. Pelo que se nota, não houve nenhum acréscimo acentuado de não respostas ao longo dos anos, mas esse raciocínio merece melhor atenção nas seções seguintes.

Outra consideração a se fazer: historicamente, os eleitores se dizem mais de 'direita' do que de 'esquerda', com uma variação entre $25 \%$ e $43 \%$ no primeiro grupo; e $18 \%$ e $29 \%$, no segundo - embora observe uma propensão de queda após 2002, época em que os governos do PT começam a dar as cartas na política nacional. No período estimado, os ditos esquerdistas superam os ditos direitistas em apenas dois momentos, em 2004 e 2012. Os centristas, por outro lado, lideram as estatísticas em 2005 e 2012. Tal circunstância, por conseguinte, destoa da propensão dos parlamentares brasileiros de se esquivarem, pelo menos no discurso, do lado direito do espectro político. Enquanto na investigação de Rodrigues (1987) um grupamento de apenas 6\% dos legisladores revelava esse pertencimento, Zucco (2011) mostra que 13,5\% dos representantes identificam-se à direita de seus partidos, aspecto que fortalece a ideia de um incômodo dos representantes com o termo.

\subsubsection{Os perfis associados ao posicionamento ideológico}

Além dos dados apresentados acerca das tendências do posicionamento ideológico nas últimas três décadas, cabe ainda retratar os perfis sociais mais propensos a se situar no eixo esquerda-direita e a assumir um dos lados do contínuo. Com efeito, serão estimados no total nove modelos econométricos, utilizando as bases do $W V S$. Com as informações contidas nesses bancos, compreendendo perguntas e escalas semelhantes e coletados em momentos distintos $(1991,2006,2014)$, nos aproximamos do horizonte temporal exami- 
nado até então.

Nos três modelos iniciais, temos como variável dependente binária o posicionamento na escala ideológica - operacionalizado como 1 para os que se posicionam e 0 para os que se abstiveram. Para tanto, utiliza-se o método de regressão probit com mínimos quadrados ponderados e erros-padrão robustos (Gelman e Hill, 2006). Os preditores considerados serão as variáveis sociodemográficas citadas, respectivamente, por Tarouco e Madeira (2013), Inglehart e Klingeman (1976) e Carreirão (2002): idade, classe $^{18}$ e sofisticação política ${ }^{19}$. Como variáveis controle, adota-se cor (branco), sexo (homem) e religião (católicos, evangélicos e outros) ${ }^{20}$. As duas primeiras por salientarem o acesso dissonante, de um lado, entre brancos e negros e, de outro, entre homens e mulheres à esfera pública, causado pela distribuição assimétrica de recursos. Logo, acredita-se que a iniquidade fomenta a disparidade de conhecimento político por essas categorias sociais (Verba, Schlozman e Brady, 1995; Delli Carpini e Keeter, 1997). Por último, as filiações religiosas, haja vista que, desde a Revolução Francesa, as esquerdas normalmente estão associadas a posturas anticlericais, aspecto que pode produzir algum efeito na ideologia dos cidadãos (Inglehart e Klingemann, 1976) ${ }^{21}$.

A tabela 2 contém os preditores da identificação ideológica nos anos analisados. Grosso modo, homens e pessoas mais sofisticadas, em concordância com Carreirão (2002), costumam apropriar-se dos vocábulos tratados para se manifestar politicamente. Os mais velhos, ao contrário das suposições de Tarouco e Madeira (2013), exibem maior dificuldade em se posicionar em relação aos mais novos, tanto em 1991 quanto em 2006.

Aqui, fica a suspeita que, por terem sido politicamente socializados durante um

\footnotetext{
${ }^{18} \mathrm{~A}$ variável classe foi instrumentalizada com perguntas sobre a posição dos cidadãos no mercado de trabalho. O WVS 2016, entretanto, não conta com essa questão e, por esse motivo, a renda foi utilizada como proxy.

${ }^{19}$ Acompanhando a construção de Inglehart e Klingemann (1976), a sofisticação política figura como uma variável compósita, mediada por três fatores distintos: habilidade, oportunidade e motivação individuais. Os itens utilizados para a formatação do indicador encontram-se no apêndice.

${ }^{20} \mathrm{~A}$ operacionalização dos preditores e da variável dependente selecionada está descrita no apêndice metodológico.

${ }^{21}$ No WVS de 1991, a porcentagem de evangélicos não chega a 4\%. Por isso, a variável religião foi operacionalizada somente com as categorias "católicos" e "outros" (referência).
} 
Tabela 2: Preditores da identificação ideológica

\begin{tabular}{lccc}
\hline & 1991 & 2006 & 2014 \\
\hline Classe média & $.05(.10)$ & $.05(.12)$ & $.12(.17)$ \\
Classe alta & $-.02(.12)$ & $-.50(.23)^{*}$ & $.06(.08)$ \\
Homem & $.30(.08)^{*}$ & $.57(.11)^{*}$ & $.29(.08)^{*}$ \\
Idade (28 a 54) & $-.27(.10)^{*}$ & $-.26(.12)^{*}$ & $.11(.10)$ \\
Idade (55 ou mais) & $-.50(.12)^{*}$ & $-.24(.16)$ & $.04(.12)$ \\
Católicos & $.19(.10)^{*}$ & $-.15(-.14)$ & $.24(.09)^{*}$ \\
Evangélicos & & $-.24(.16)$ & $04(.11)$ \\
Ensino médio & $.18(.10)$ & $.03(.11)$ & $.29(.09)^{*}$ \\
Ensino superior & $.80(.18)^{*}$ & $1.3(.37)^{*}$ & $.50(.12)^{*}$ \\
Cor (branco) & $.32(.10)^{*}$ & $14(.10)$ & $-.12(07)$ \\
McFadden & 0.31 & 0.14 & 0.08 \\
N & 1388 & 1402 & 1446 \\
\hline
\end{tabular}

Nota: Erros-padrão robustos entre parênteses.

Fonte: World Values Survey.

* Significância estatística a .05.

período autoritário, com a supressão da liberdade de legendas partidárias em polos distintos, as gerações mais antigas carecem do arcabouço informacional adequado para tal discernimento. Isto posto, salienta-se que o comportamento e as visões de mundo dos eleitores são, via de regra, moldados pela competição intra elites, ou seja, estas afetam os primeiros ao ativar clivagens específicas e fornecer as informações concernentes aos termos em disputa (Kitscheldt e Hellemans, 1990). Acredita-se, por conseguinte, que o componente da expansão democrática assuma um caráter de distinção entre a população brasileira.

Os resultados de 1991 e 2014 também apontam para a importância da denominação religiosa: professar uma religião que não a católica diminui as chances de declaração ideológica. De resto, cor só é um diferencial para os dados da década de 1990, e classe, em consonância com os achados de Inglehart e Klingemann (1976), não expressou significância estatística nos anos investigados.

No caso dos posicionamentos ideológicos, as tabelas 3, 4 e 5 expõem as porcentagens associadas a cada uma das categorias ${ }^{22}$. À primeira vista, os ditos esquerdistas figuram 
nas camadas mais altas, são mais jovens, menos religiosos, possuem níveis de escolaridade superiores e se autointitulam brancos. Os direitistas, o contrário: ocupam as posições mais baixas, têm idade avançada e professam fé sobretudo no catolicismo e no protestantismo. Os centristas não exibem traços particulares se comparados às outras duas categorias.

Tabela 3: Perfis associados às categorias ideológicas (1991).

\begin{tabular}{|c|c|c|c|}
\hline & Esquerda & Centro & Direita \\
\hline \multicolumn{4}{|c|}{ Classe social } \\
\hline Baixa & $13 \%$ & $20 \%$ & $35 \%$ \\
\hline Média & $59 \%$ & $55 \%$ & $51 \%$ \\
\hline Alta & $28 \%$ & $25 \%$ & $15 \%$ \\
\hline \multicolumn{4}{|l|}{ Idade } \\
\hline$<28$ & $53 \%$ & $41 \%$ & $31 \%$ \\
\hline 28 a 54 & $39 \%$ & $40 \%$ & $37 \%$ \\
\hline$>55$ & $08 \%$ & $19 \%$ & $32 \%$ \\
\hline \multicolumn{4}{|l|}{ Sexo } \\
\hline Homem & $55 \%$ & $54 \%$ & $49 \%$ \\
\hline Mulher & $45 \%$ & $46 \%$ & $51 \%$ \\
\hline \multicolumn{4}{|l|}{ Religião } \\
\hline Outros & $27 \%$ & $22 \%$ & $20 \%$ \\
\hline Católico & $73 \%$ & $78 \%$ & $80 \%$ \\
\hline \multicolumn{4}{|c|}{ Escolaridade } \\
\hline Primário & $20 \%$ & $21 \%$ & $38 \%$ \\
\hline Médio & $61 \%$ & $61 \%$ & $51 \%$ \\
\hline Superior & $19 \%$ & $18 \%$ & $11 \%$ \\
\hline \multicolumn{4}{|l|}{ Cor } \\
\hline Outros & $18 \%$ & $18 \%$ & $21 \%$ \\
\hline Brancos & $82 \%$ & $82 \%$ & $79 \%$ \\
\hline
\end{tabular}

Fonte: Elaboração própria/ WVS 1991. 
Tabela 4: Perfis associados às categorias ideológicas (2006).

\begin{tabular}{|c|c|c|c|}
\hline & Esquerda & Centro & Direita \\
\hline \multicolumn{4}{|c|}{ Classe social } \\
\hline Baixa & $09 \%$ & $12 \%$ & $11 \%$ \\
\hline Média & $31 \%$ & $33 \%$ & $37 \%$ \\
\hline Alta & $60 \%$ & $55 \%$ & $51 \%$ \\
\hline \multicolumn{4}{|l|}{ Idade } \\
\hline$<28$ & $35 \%$ & $27 \%$ & $27 \%$ \\
\hline 28 a 54 & $52 \%$ & $52 \%$ & $50 \%$ \\
\hline$>55$ & $13 \%$ & $21 \%$ & $23 \%$ \\
\hline \multicolumn{4}{|l|}{ Sexo } \\
\hline Homem & $56 \%$ & $56 \%$ & $56 \%$ \\
\hline Mulher & $43 \%$ & $44 \%$ & $43 \%$ \\
\hline \multicolumn{4}{|l|}{ Religião } \\
\hline Outros & $28 \%$ & $18 \%$ & $13 \%$ \\
\hline Católicos & $55 \%$ & $61 \%$ & $64 \%$ \\
\hline Evangélicos & $16 \%$ & $21 \%$ & $23 \%$ \\
\hline \multicolumn{4}{|c|}{ Escolaridade } \\
\hline Primário & $39 \%$ & $48 \%$ & $54 \%$ \\
\hline Médio & $38 \%$ & $35 \%$ & $33 \%$ \\
\hline Superior & $22 \%$ & $16 \%$ & $13 \%$ \\
\hline \multicolumn{4}{|l|}{ Cor } \\
\hline Outros & $45 \%$ & $46 \%$ & $52 \%$ \\
\hline Brancos & $55 \%$ & $54 \%$ & $48 \%$ \\
\hline
\end{tabular}

Fonte: Elaboração própria/ WVS 2006.

Mais uma vez serão estimadas regressões para apurar de forma detalhada os elementos demográficos. Aqui, no entanto, foi utilizado um teste multinomial, com o centro como categoria de referência, conforme explicitado na tabela 6 . 
Tabela 5: Perfis associados às categorias ideológicas (2014).

\begin{tabular}{|c|c|c|c|}
\hline & Esquerda & Centro & Direita \\
\hline \multicolumn{4}{|c|}{ Classe social } \\
\hline Baixa & $41 \%$ & $42 \%$ & $51 \%$ \\
\hline Média & $55 \%$ & $52 \%$ & $42 \%$ \\
\hline Alta & $04 \%$ & $06 \%$ & $07 \%$ \\
\hline \multicolumn{4}{|l|}{ Idade } \\
\hline$<28$ & $24 \%$ & $23 \%$ & $17 \%$ \\
\hline 28 a 54 & $56 \%$ & $57 \%$ & $48 \%$ \\
\hline$>55$ & $20 \%$ & $19 \%$ & $35 \%$ \\
\hline \multicolumn{4}{|l|}{ Sexo } \\
\hline Homem & $57 \%$ & $60 \%$ & $64 \%$ \\
\hline Mulher & $42 \%$ & $40 \%$ & $36 \%$ \\
\hline \multicolumn{4}{|l|}{ Religião } \\
\hline Outros & $24 \%$ & $23 \%$ & $17 \%$ \\
\hline Católicos & $56 \%$ & $57 \%$ & $48 \%$ \\
\hline Evangélicos & $20 \%$ & $19 \%$ & $35 \%$ \\
\hline \multicolumn{4}{|c|}{ Escolaridade } \\
\hline Primário & $37 \%$ & $36 \%$ & $56 \%$ \\
\hline Médio & $44 \%$ & $43 \%$ & $31 \%$ \\
\hline Superior & $19 \%$ & $21 \%$ & $13 \%$ \\
\hline \multicolumn{4}{|l|}{ Cor } \\
\hline Outros & $55 \%$ & $50 \%$ & $56 \%$ \\
\hline Brancos & $45 \%$ & $50 \%$ & $43 \%$ \\
\hline
\end{tabular}

Fonte: Elaboração própria/ WVS 2014.

Nas regressões, os esquerdistas diferenciam-se dos centristas primordialmente pelo elemento religioso. Em 2006 e 2014, católicos e evangélicos tendem a evitar o conceito. A classe social anuncia significância estatística em 1991, quando os estratos médios da população preferem se declarar à esquerda. No mesmo ano, idade - sendo os jovens mais afeitos - e os níveis menos elevados de escolaridade são outros preditores sintomáticos. 
Tabela 6: Preditores do posicionamento ideológico à esquerda e à direita

\begin{tabular}{|c|c|c|c|}
\hline \multicolumn{4}{|c|}{ Painel A - Posicionamento à esquerda } \\
\hline & 1991 & 2006 & 2014 \\
\hline Classe média & $.48(.20)^{*}$ & $.03(.23)$ & $.32(.34)$ \\
\hline Classe baixa & $.44(.22)$ & $-.09(.24)$ & $.43(.33)$ \\
\hline Homem & $.16(.14)$ & $-.06(.14)$ & $.03(.14)$ \\
\hline Idade (28 a 54) & $-.27(.15)$ & $-.15(.16)$ & $-.09(.17)$ \\
\hline Idade (55 ou mais) & $-1.27(.25)^{*}$ & $-.65(.23)^{*}$ & $-.01(.23)$ \\
\hline Católicos & $-.27(.16)$ & $-.54(.17)^{*}$ & $-.38(.17)^{*}$ \\
\hline Evangélicos & & $-.78(.22)^{*}$ & $-.31(.20)$ \\
\hline Escolaridade (ensino médio) & $-.49(.20)^{*}$ & $.07(.17)$ & $-.01(.16)$ \\
\hline Escolaridade (ensino superior) & $-.37(.24)$ & $.24(.22)$ & $-.14(.20)$ \\
\hline Cor (branco) & $.01(.18)$ & $-.01(.14)$ & $-.22(.14)$ \\
\hline Qui-quadrado & $110.73^{*}$ & $53.788^{*}$ & $77.31^{*}$ \\
\hline \multicolumn{4}{|c|}{ Painel B - Posicionamento à direita } \\
\hline & 1991 & 2006 & 2014 \\
\hline Classe média & $.30(.20)$ & $.29(.24)$ & $-.24(.30)$ \\
\hline Classe baixa & $.47(.21)^{*}$ & $.34(.24)$ & $-.51(.30)$ \\
\hline Homem & $-.16(.14)$ & $.04(.13)$ & $-.17(.15)$ \\
\hline Idade (28 a 54) & $.23(.16)$ & $-.05(.16)$ & $-.02(.19)$ \\
\hline Idade (55 ou mais) & $.51(.21)^{*}$ & $.02(.21)$ & $.71(.23)^{* *}$ \\
\hline Católicos & $.14(.18)$ & $.31(.19)$ & $-.05(.18)$ \\
\hline Evangélicos & & $.33(.22)$ & $.04(.22)$ \\
\hline Escolaridade (ensino médio) & $-.56(.18)^{* *}$ & $-.10(.16)$ & $-.54(.17)^{* *}$ \\
\hline Escolaridade (ensino superior) & $-.86(.24)^{* * *}$ & $-.10(.22)$ & $-.70(.22)^{* *}$ \\
\hline Cor (branco) & $-.18(.18)$ & $-.22(.13)$ & $-.27(.14)$ \\
\hline Qui-quadrado & $110.73^{* * *}$ & $53.788^{* * *}$ & $77.31^{* * *}$ \\
\hline
\end{tabular}

Nota: Erros-padrão robustos entre parênteses.

Fonte: World Values Survey.

* Significância estatística a .05.

A sofisticação, por sinal, figura como um distintivo dos centristas. Se comparados aos direitistas, esse grupo manifesta os maiores graus de instrução. Ao contrário dos esquerdistas, contudo, a direita tem nas antigas gerações o seu público alvo. Sexo e cor não se mostraram relevantes para a discriminação desse grupamento; enquanto os segmentos menos privilegiados caminham na contramão das expectativas de Inglehart e Klingemann (1976), preferindo uma identidade à direita. Nota-se, então, a deterioração 
das classes sociais como preditores do posicionamento ideológico nas décadas subsequentes aos anos 1990.

Não obstante, cumpre lembrar que a escala de autoposicionamento ideológico apresenta duas sérias limitações: 1) o alto índice de não respostas e, principalmente, 2) o desconhecimento semântico do significado das categorias entre os respondentes (Almeida, 2011). Assim, mesmo os que se posicionam adotam essas identificações por diversas razões valorativas e simbólicas (Stimson, 2004), podendo impor acepções distintas ao contínuo (Zumbrunnem e Gangl, 2008) e/ou manter orientações diversas através de domínios de conceituação heterogêneos (Layman e Carsey, 2002).

\subsection{Esquerda e direita ou situação versus oposição?}

Se a principal atribuição aos conceitos esquerda e direita nos questionários semiabertos dos anos 1990 está condicionada à percepção do espaço ocupado pelos partidos no embate político (Carreirão, 2002), cabe a análise de uma possível continuidade dessa tendência no Brasil ao longo do século XXI. Com efeito, o exame fica comprometido pela falta de sequência desse tipo de consulta nas pesquisas surveys de idos mais atuais.

Em artigo recente, todavia, Telles e Storni (2011) exploram a perenidade dessa associação na cidade de Belo Horizonte, em Minas Gerais (MG), e chegam à conclusão que o resultado da diferenciação segue pautado pelo julgamento das ações governamentais. Ou seja, à medida que o partido incumbente se encontra bem avaliado pelo eleitor, maiores as chances dos cidadãos se posicionarem à direita e, de modo contrário, à esquerda. Assim, constatam:

A alteração das forças que controlam o governo não correspondeu à renovação no conceito de esquerda e direita. Na percepção do eleitor, 'ser de esquerda' ou 'ser de direita' se manteve como similar à encontrada nos anos de regime autoritário. Naquele período, o governo militar era identificado com a direita, reforçando a associação entre de um lado política de direita e governo/situação; de outro, as forças de esquerda atuavam como opositoras. Muitas destas organizações agiam de fora da ordem institucional estabelecida 
e esta escolha estratégica permitiu que ao significado de esquerda fossem conferidos outros sentidos, tais como o grupo político que age 'fora da ordem' (Telles e Storni, 2011:5).

Portanto, segundo os autores, quando o PT - ideologicamente à esquerda no sistema partidário brasileiro - passa a controlar o Executivo federal, a legenda "vira o fio" e deslocase para o lado direito do espectro político no entendimento da população. Tal aspecto seria explicado tanto pelo enraizamento dessa lógica no imaginário do eleitorado, quanto por conta da durabilidade intrínseca ao significado das palavras.

A consulta a bases nacionais, contudo, não comprova os argumentos da dupla. Na figura 3, constam o posicionamento ideológico do PT e de seu principal adversário no pleito presidencial, o PSDB, na compreensão dos respondentes do Estudo Eleitoral Brasileiro (ESEB), em 2002, 2006, 2010 e 2014. O partido de Lula ocupa a esquerda do contínuo ideológico para a maioria dos entrevistados em todos os anos. Em contrapartida, o PSDB permanece conectado à direita, mesmo fazendo oposição sistemática ao Executivo Federal desde 2003.

Figura 3: Percepções de PT e PSDB quanto ao posicionamento ideológico
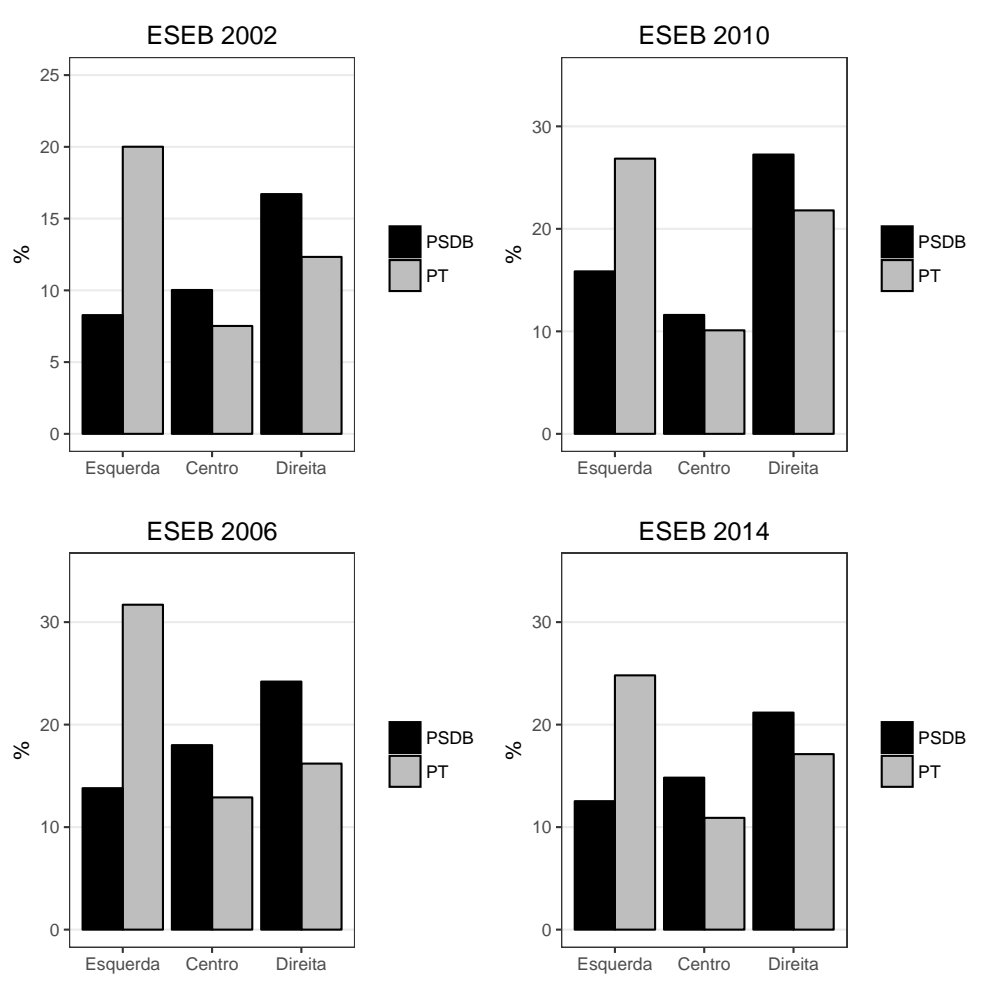
Isto posto, fica a impressão que os achados de Telles e Storni (2011) foram influenciados por um contexto sui generis da disputa partidária em MG. Como ratificam os próprios autores, as alianças PT-PSDB na capital mineira podem ter tornado as diferenças ideológicas entre petistas e tucanos menos claras para os eleitores da região.

\subsection{Análise dos componentes ideológicos}

Se os indivíduos imputam significados distintos ou atribuem suas avaliações aos rótulos em pauta a partir de fontes simbólico-afetivas, precisamos levar em consideração fatores esquecidos pela literatura nacional para entender melhor os condicionantes desse posicionamento. A escolha dos WVS justifica-se em virtude da representatividade das amostras e pelo fato destas conterem um número maior de questões de posição - isto é, temas responsáveis pelas divisões de opinião no eleitorado (Stokes, 1963) -, adequando-se melhor à elaboração teórica proposta neste capítulo. Em ambas, além da quantidade dos itens, as escalas dos questionamentos, divididas em múltiplos pontos, ajudam a definir de forma mais acurada as inclinações dos respondentes. Aqui, as bases investigadas são as edições do WVS de 1991 e 2014, em virtude da dessemelhança de alguns itens na versão de 2006.

A variável dependente continua sendo a escala delimitadora dos eixos esquerda e direita, com os maiores valores relacionados à direita. Os três componentes salientados por Inglehart e Klingemann (1976) serão postos em questão aos moldes de preditores independentes em uma regressão linear. Esse tipo de tratamento pretende evitar inferências espúrias, uma vez que certas pessoas podem, por exemplo, se identificar com a esquerda e apoiar determinados partidos simplesmente porque se sentem identificados com a classe trabalhadora.

Para começar o receituário, o elemento mais difícil de diagnosticar: o ingrediente valorativo. Tendo em vista que as clivagens sociais costumam diferir de acordo com os países, o foco passa a ser uma série extensiva de issues, usualmente facultados a um ou outro lado do espectro político. Dessa forma, abrimos o horizonte às especificidades do caso nacional. Certamente, os temas em evidência não esgotam o universo de embates sociais, mas funcionam enquanto indicadores centrais dessa polarização. 
A primeira dessas matérias são os tópicos econômicos, os quais capturam o significado clássico da divisão esquerda-direita (Downs, 1957; Bobbio, 1996) e, segundo alguns autores, denotam a principal dimensão da disputa partidária na América Latina (Kitscheldt et al., 2010; Wiesehomeier e Doyle, 2012; Baker e Greene, 2015). Nesse ponto, a esquerda distancia-se da direita por uma maior preocupação com a igualdade. Na segunda, as questões sociais, com os direitistas apoiando preceitos tradicionais, e os esquerdistas correligionários de posturas liberais concernentes aos costumes. Por último, a defesa da ordem, conforme enfatizaram Singer (1999) e Ames e Smith (2010), dado que a direita normalmente concebe de maneira positiva uma noção subjacente de autoridade, social ou metafísica, para confrontar possíveis distúrbios, como greves e manifestações (Laponce, 1972).

Esse quesito, por conseguinte, ocupa posição central na história recente do Brasil, já que, desde o início dos anos 1980, com os partidos de oposição novamente autorizados a se envolver na cena política nacional, o adensamento da democracia foi posto em jogo pelas legendas de esquerda, confrontando um legado autoritário de regime, implantado após o golpe de 1964 (Dagnino, Rivera e Panfichi, 2006; Goldfrank, 2011). O estatuto da representação seria combinado com práticas de democracia direta, especialmente em nível municipal, com o objetivo não só de aprofundar o sistema político, mas também de consolidar alianças com os movimentos sociais. Por conta disso, especula-se, a temática é a que mais aparece em evidência nos estudos acerca das bases valorativas do pensamento ideológico dos brasileiros.

Detidamente, as sentenças que mais assumem a distinção esquerda-direita são:

- Empresas e negócios particulares devem aumentar.

- Os salários deveriam ser mais parecidos.

- A concorrência é boa porque estimula as pessoas a trabalhar mais e desenvolver novas ideias.

- Não é justificável: sexo antes do casamento.

- Não é justificável: homossexualidade.

- Não é justificável: aborto. 
- Não é justificável: divórcio.

- Atos que nunca participaria: greves.

- Atos que nunca participaria: boicotes.

- Atos que nunca participaria: manifestações.

Importa dizer, todas as questões destacadas têm taxas de não respostas menores quando comparadas ao autoposionamento ideológico, conforme a figura 4. Nenhuma delas ultrapassa a casa dos $10 \%$ nos dois anos, ao passo que a escala unidimensional apresenta índices de $17 \%$ e $20 \%$ nos períodos assinalados.

Figura 4: Taxas de não respostas das questões destacadas (1991 e 2014)

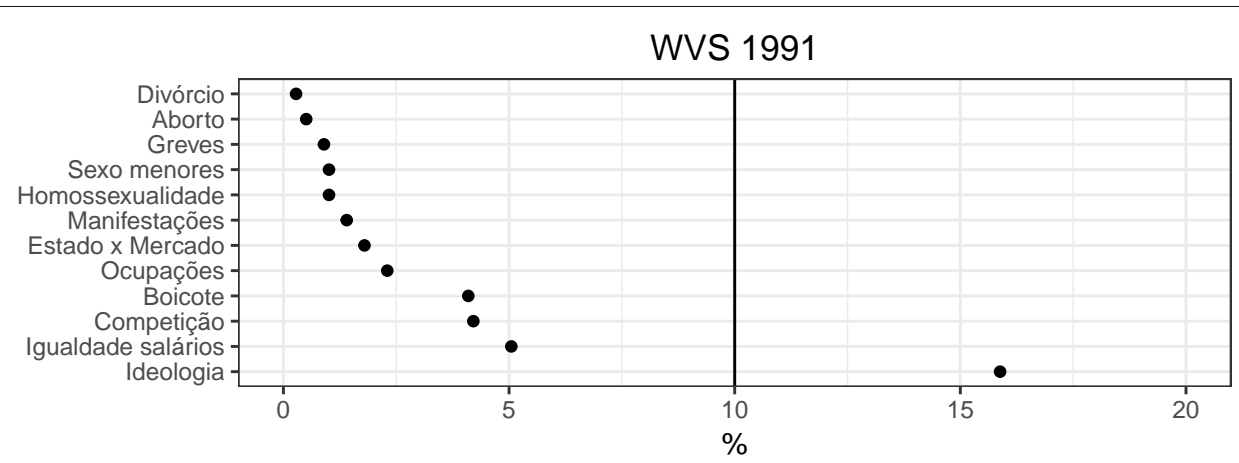

WVS 2014



Fonte: elaboração própria/ WVS 1991 e WVS 2014.

Outro componente relevante é a investigação da correspondência desses tópicos com a mensuração da metáfora espacial. Na tabela 7 , nota-se que a diferença entre os blocos ideológicos normalmente se atém a matérias atinentes à ordem. Em 2014, contudo, a discordância em relação à igualdade de salários, o sexo antes do casamento e a homossexualidade também revelam significância estatística no teste do qui-quadrado. 
Tabela 7: Correspondência entre as questões de posição e o autoposicionamento ideológico

\begin{tabular}{lccc}
\hline \multicolumn{4}{c}{ Painel A: WVS 1991 } \\
\hline & Esquerda & Centro & Direita \\
\hline Estado x Mercado (a favor) & $44 \%$ & $45 \%$ & $45 \%$ \\
Igualdade de salários (contra) & $40 \%$ & $45 \%$ & $47 \%$ \\
Competição (a favor) & $68 \%$ & $68 \%$ & $72 \%$ \\
Sexo antes casamento (contra) & $73 \%$ & $77 \%$ & $0.82 \%$ \\
Homossexualidade (contra) & $88 \%$ & $92 \%$ & $92 \%$ \\
Aborto (contra) & $91 \%$ & $92 \%$ & $0.94 \%$ \\
Divórcio (contra) & $63 \%$ & $69 \%$ & $68 \%$ \\
Greves (contra)* & $43 \%$ & $52 \%$ & $61 \%$ \\
Boicotes (contra)* & $28 \%$ & $36 \%$ & $47 \%$ \\
Manifestações (contra)* & $62 \%$ & $73 \%$ & $79 \%$ \\
\hline
\end{tabular}

Painel B: WVS 2014

\begin{tabular}{lccc}
\hline & Esquerda & Centro & Direita \\
\hline Estado x Mercado (a favor) & $44 \%$ & $40 \%$ & $35 \%$ \\
Igualdade de salários (contra)* & $32 \%$ & $34 \%$ & $47 \%$ \\
Competição (a favor) & $63 \%$ & $61 \%$ & $60 \%$ \\
Sexo antes casamento (contra)* & $46 \%$ & $49 \%$ & $55 \%$ \\
Homossexualidade (contra)* & $70 \%$ & $71 \%$ & $78 \%$ \\
Aborto (contra) & $86 \%$ & $93 \%$ & $93 \%$ \\
Divórcio (contra) & $49 \%$ & $47 \%$ & $54 \%$ \\
Greves (contra)* & $42 \%$ & $47 \%$ & $57 \%$ \\
Boicotes (contra)* & $46 \%$ & $48 \%$ & $60 \%$ \\
Manifestações (contra)* & $40 \%$ & $42 \%$ & $53 \%$ \\
Protestos (contra) & $44 \%$ & $45 \%$ & $49 \%$ \\
\hline
\end{tabular}

Fonte: elaboração própria/ WVS 1991 e WVS 2014. Nota: os itens com asteriscos apresentam qui-quadrado significativo a 0,05 .

Com a finalidade de mensurar as fontes afetivas do posicionamento ideológico, recorre-se a ícones políticos diversos, como grupos e legendas partidárias, que se encarregam de alavancar as representações simbólicas de algumas clivagens da sociedade brasileira. Especificamente, tem-se em conta a identificação com os grupamentos destacados: sindicatos, associações de direitos humanos, movimento feminista, grandes corporações empresariais, forças armadas e a polícia. Os três primeiros relacionados ao pertencimento com a esquerda; os três últimos, com a direita. A identificação partidária, acompanhando 
recentes trabalhos da literatura, tem o PT em seu cerne, por ser uma espécie de âncora do sistema partidário nacional, conciliando as maiores simpatia e, a um só tempo, rejeição dos brasileiros (Carreirão e Barbetta, 2004).

Sendo assim, foram construídas escalas, a partir dos diferentes itens, com a técnica de Análise Fatorial ${ }^{24}$. Do catálogo de modelos psicométricos, talvez a análise fatorial seja a técnica mais utilizada. A ideia por trás da operação é bastante simples: se indicadores individuais forem medidas confiáveis de uma variável latente, eles apresentarão altos níveis de correlação, justificando uma apreciação compósita do construto. A escala então criada desempenha o papel de distinguir entre as unidades investigadas, atribuindo-lhes escores fixos. Formalmente, a representação do modelo pode ser descrita como:

$$
X_{i j}=\mu_{j}+\lambda_{i 1}+\xi_{i 1}+\lambda_{i 2}+\xi_{i 2}+\ldots+\lambda_{i k}+\xi_{i k}+\delta_{i j}
$$

Em que $i$ são as unidades de análise e $j$ são os indicadores. Assim, na análise fatorial temos um modelo no qual os indicadores sempre apresentam um número maior que os fatores, expostos pela letra $\xi$. Os $\lambda$ retratam os coeficientes fatoriais estimados, $\mu j$ a média de $X_{i j}$ e $\delta$ a parte não contabilizada pela combinação das variáveis $k$ presentes no modelo. De particular importância, os $\lambda$ revelam o quanto as variáveis observáveis se ligam à variável latente. Nesse sentido, quanto maiores os valores do parâmetro, maior a correlação com $\xi$. Como pressuposto básico da equação, a conceito de independência local, ou seja, a ausência de correlação entre os erros de mensuração e os valores dos fatores latentes. Para o cálculo dos parâmetros são necessárias algumas restrições. As estratégias mais comuns sustentam a fixação de um item ou caso em uma dimensão estipulada.

Existem dois tipos análise fatorial, as abordagens exploratória (AFE) e confirmatória (AFC). Ambas são baseadas nos postulados acima indicados. A diferença entre as vertentes situa-se no grau de interferência dos pesquisadores nos modelos estimados. Isto posto, a AFE é mais indicada para os estágios iniciais de exploração dos dados, quando sabemos pouco a respeito do conjunto de variáveis estudadas. A AFC, de outro lado, exige a especificação a priori dos padrões dos coeficientes e a vinculação dos itens com os compostos latentes. Portanto, nas ocasiões em que o autor tem uma maior fundamen-

\footnotetext{
${ }^{24}$ Os coeficientes da análise fatorial, bem como a operacionalização dos itens, estão no apêndice.
} 
tação empírica e teórica, a AFC é o método recomendado (Fabrigar et al., 1999; Reise et al., 2000) e será utilizada no presente trabalho ${ }^{25}$. À guisa de exemplo, as figuras (5 e 6) evidenciam, de modo esquemático, os construtos latentes operacionalizados, em que os retângulos representam as variáveis observáveis, enquanto os círculos constituem as escalas latentes.

Figura 5: Modelo latente com as questões de posição

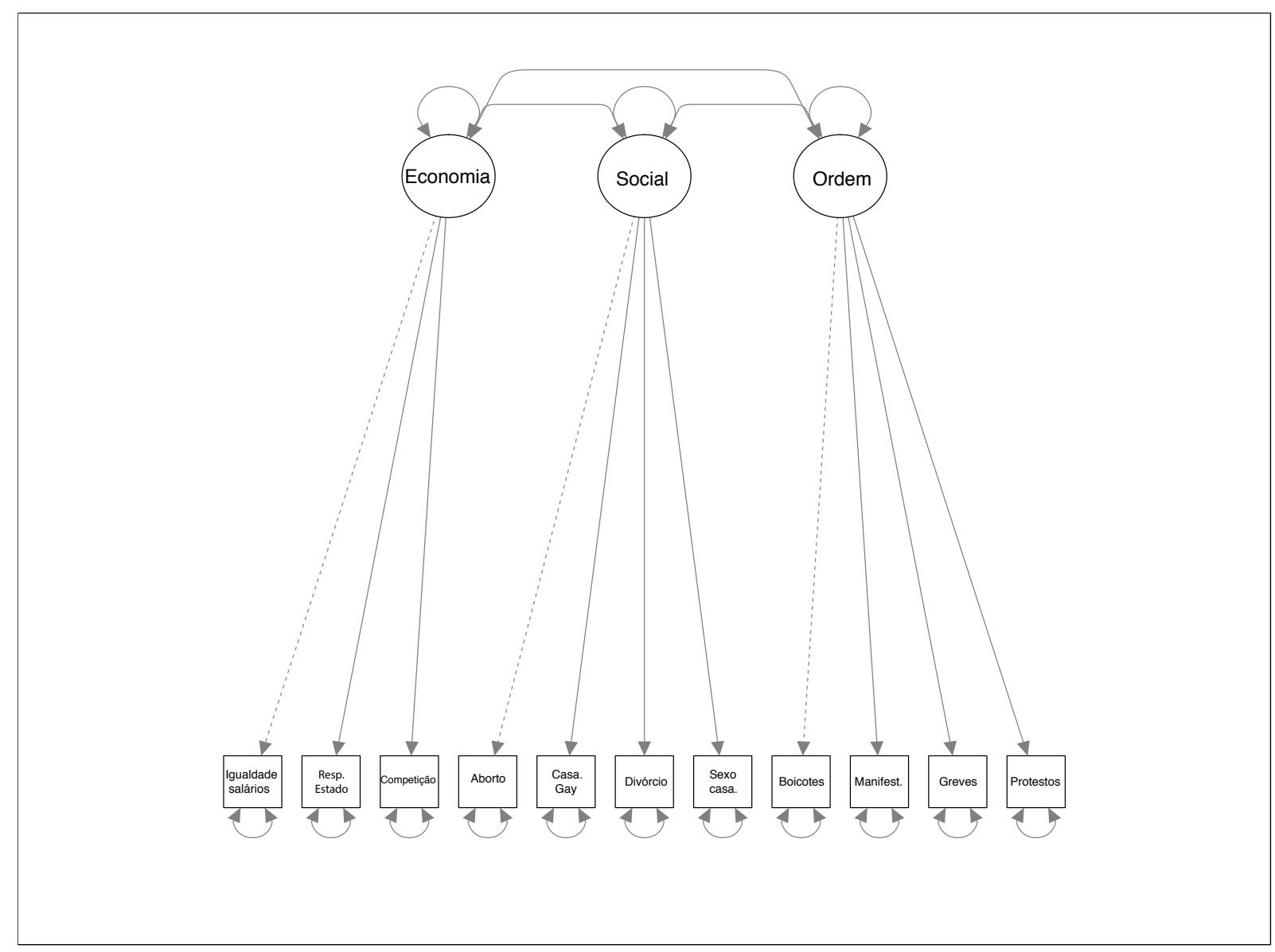

Como foi dito na introdução, a vantagem de se trabalhar com escalas compostas de múltiplas medidas é a de conter os impactos dos erros de mensuração, tipicamente atinentes a pesquisas fundamentadas em questões individuais (Ansolabehere et al., 2008). Além

\footnotetext{
${ }^{25}$ Nesse ponto, cabe uma ressalva, em virtude da costumeira confusão atinente ao assunto: o objetivo de revelar variáveis latentes é diferente do intuito de reduzir os dados. Assim sendo, técnicas como a Análise de Componentes Principais (ACP), não se atém à estrutura de correlação das variáveis observáveis, apenas sintetizam os escores dos preditores em um conjunto comprimido de escalas compósitas (Fabrigar, 1999). A ACP não diferencia a estrutura comum e a variância individual dos regressores. Dessa maneira, é conceitualmente incorreto enquadrar a ACP dentro do escopo das Análises Fatoriais.
} 
disso, reduz-se prováveis problemas de multicolinearidade. Na construção das escalas, os escores mais elevados estão ligados a posicionamentos conservadores. Como consequência, temos as dimensões subsequentes listadas abaixo, com as respectivas perguntas utilizadas na ponderação dos fatores e suas estimativas de confiabilidade ${ }^{26}$.

Figura 6: Modelo latente com os símbolos sociais

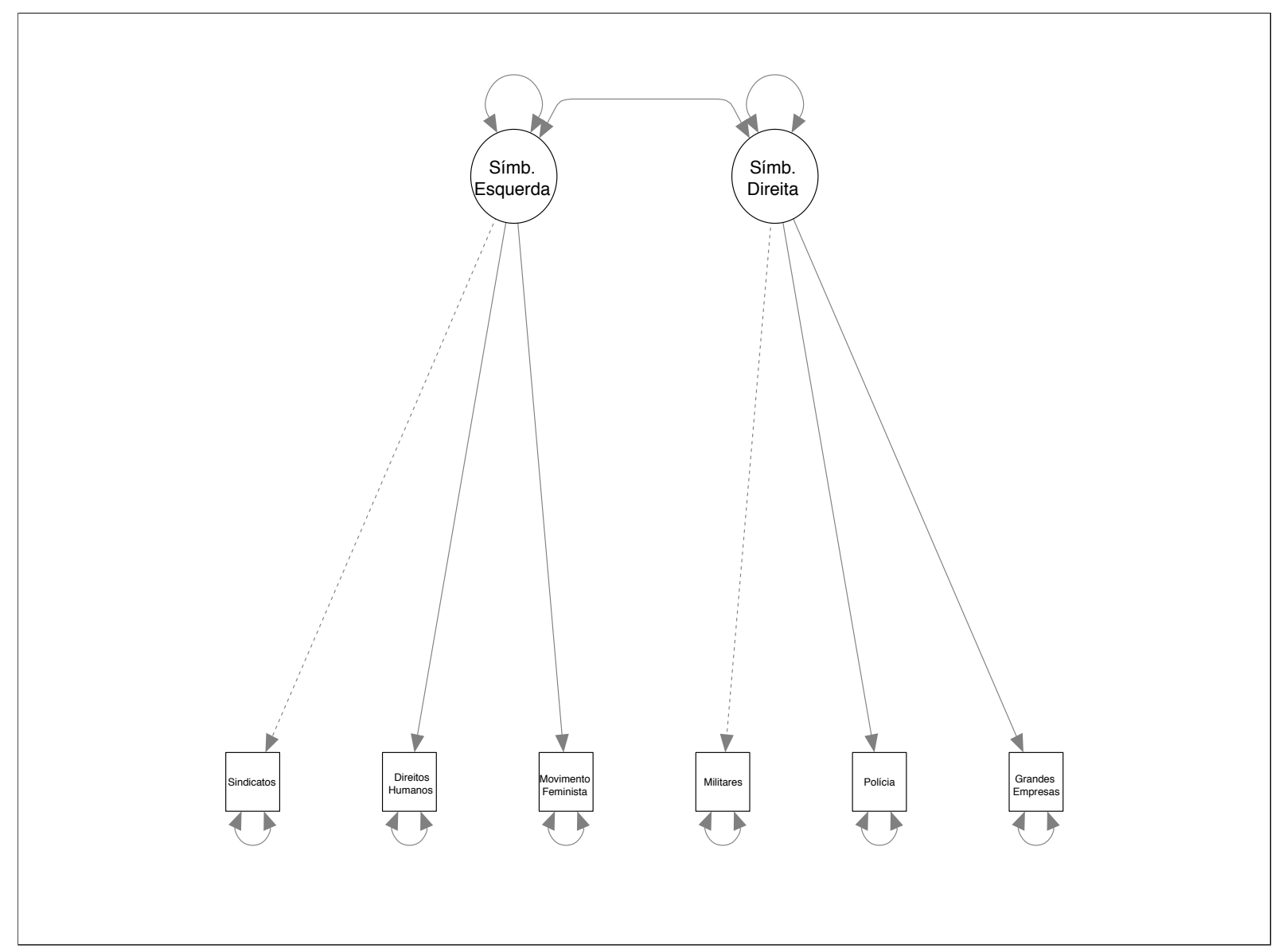

Como medidas de controle, adicionou-se os preditores sociodemográficos que demonstraram relevância estatística: sofisticação política, idade, classe social e religião. Os resultados das regressões lineares figuram na tabela 9, exibindo os estimadores de efeitos relativos dos aspectos valorativos e simbólicos por ano. As variáveis independentes foram inseridas em blocos nos modelos. Na etapa 1, introduziu-se somente os indicadores dos valores nas equações e a variância do posicionamento ideológico explicada por esses preditores ( $\mathrm{R}^{2}$ ajustado). Na sequência, combinam-se a eles a perspectiva simbólica na etapa 2 ,

${ }^{26}$ Como medida de confiabilidade adotou-se o Alpha de Cronbach, um estimador de consistência interna do fator. Lembrando que, quanto maior o valor do alpha, maior o relacionamento entre as variáveis. Os coeficientes mínimos considerados aceitáveis para a medida ficam em torno de 0,5 (Reise, 2000). 
com os fatores sociais. Na etapa 3, ponderou-se os aspectos sociodemográficos. Nos dois passos derradeiros constam os efeitos totais e o impacto independente de cada conjunto de variáveis (em parênteses) - por exemplo, no segundo modelo estimado, temos, além do $\mathrm{R}^{2}$ ajustado, o resultado dos componentes sociais controlado pelos elementos valorativos. Os preditores mais importantes dos modelos estão destacados em negrito.

Tabela 8: Índices de confiabilidade dos itens

\begin{tabular}{l|l}
\hline Valores & Aspectos Simbólicos \\
\hline Economia & Símbolos Esquerda \\
Igualdade de Salários & Sindicatos \\
Estado x Mercado & Grupos de Direitos Humanos \\
Competição & Movimento feminista \\
$\alpha(1991)=.52 ; \alpha(2014)=.52$ & $\alpha(1991)=.57 ; \alpha(2014)=.64$ \\
Social & Símbolos Direita \\
Divórcio & Polícia \\
Homossexualidade & Forças Armadas \\
Aborto & Corporações Empresariais \\
$\alpha(1991)=.67 ; \alpha(2014)=.55$ & $\alpha(1991)=.63 ; \alpha(2014)=.61$ \\
Ordem & \\
Greves & \\
Manifestações & \\
Boicotes & \\
$\alpha(1991)=.69 ; \alpha(2014)=.77$ & \\
\hline
\end{tabular}

Nota: Os índices de confiabilidade das escalas são representados pelos coeficientes $\alpha$.

O impacto dos valores confirma os trabalhos que lidam com a hipótese da vinculação de noções cognitivas com a ideologia no Brasil. Primeiro, os modelos explicam pouco a variação do posicionamento ideológico - com 14,8\%, em 1991, e somente 4,8\%, em 2014. Todavia, alguns preditores mostraram-se consistentes e possibilitam uma análise particularizada. 
Tabela 9: Preditores do posicionamento ideológico

\begin{tabular}{lcc}
\hline & 1991 & 2014 \\
\hline Etapa 1: Valores & & \\
Economia & $.07(.15)$ & $.36(.21)$ \\
Social & $.11(.13)$ & $.10(.17)$ \\
Ordem & $.39(.13)^{*}$ & $.45(.16)^{*}$ \\
Etapa 2: Aspectos Simbólicos & & \\
Símbolos Esquerda & $-.02(.34)$ & $.43(.27)$ \\
Símbolos Direita & $1.06(.15)^{*}$ & $.42(.16)^{*}$ \\
Id. Partidária (PT) & $-1.28(.19)^{*}$ & $.19(.22)$ \\
Etapa 3: Aspectos Sociodemográficos & & \\
Sofisticados & $.01(.01)$ & $-.01(.01)$ \\
Idade (55 ou +) & $.09(.01)^{*}$ & $.07(.01)^{*}$ \\
Classe Média & $-.01(.01)$ & $-.02(.01)$ \\
Classe Alta & $-.01(.01)$ & $-.01(.02)$ \\
Religião (Católicos) & $.00(.01)$ & $.01(.01)$ \\
Religião (Evangélicos) & & $.02(.02)$ \\
$\mathrm{N}$ & 1.486 & 1.118 \\
$\mathrm{R}^{2}$ ajustados \% (Etapa 1) & 4.2 & 1.5 \\
$\mathrm{R}^{2}$ ajustados \% (Etapa 2) & $\mathbf{1 1 . 7}$ & $\mathbf{3 . 4}$ \\
& $(7.5)$ & $(1.9)$ \\
$\mathrm{R}^{2}$ ajustados \% (Etapa 3) & 13.8 & 4.2 \\
& $(6.3)$ & $(0.8)$ \\
\hline
\end{tabular}

Nota: Os erros-padrão estão entre parênteses.

Em consonância com as observações de Singer (1999) e Ames e Smith (2010), a defesa da ordem, ou "a contestação da autoridade do Estado na sua função repressiva em relação aos movimentos sociais"(Singer, 2000:20), é mesmo o principal tema na identificação ideológica. O fator mostra-se resiliente tanto no processo de democratização do país, em 1991, quanto nos dias atuais. Já as dimensões econômica e social, que figuram na literatura internacional como critérios de diferenciação entre esquerdistas e direitistas, não ostentam índices estatísticos significativos nos anos ponderados, fato constatado por Bonifácio et al., (2014), Oliveira e Turgeon (2015) e Carlin et al (2015). Por não atentarem para o embate da inclusão política versus ordem, ambos concluíram em favor da tese da ausência completa de constrição no pensamento ideológico dos brasileiros. 
Isto posto, são os ingredientes afetivos, notadamente os signos sociais subjetivos, os princípios prevalecentes do discernimento da metáfora espacial (Inglehart, 1976). Embora os símbolos de esquerda não demonstrem muita consistência, os dísticos sociais relacionados ao conservadorismo expressam associação significativa entre os componentes. Em 1991 e 2014, a simbologia supera, inclusive, o tópico valorativo do compromisso com a ordem.

No que tange à identificação partidária, a simpatia com o PT galvanizou desacordos com o ícone da direita em 1991, mas não em 2014²7. Lembrando o raciocínio de Carreirão (2008), sublinhado na seção 3, conquanto o número daqueles que se abstêm de usar o eixo esquerda-direita não tenha aumentado nos últimos anos, o PT perdeu força como signo ideológico se comparado com o início dos anos 1990. Naqueles idos, de fato, o partido cultivava uma identidade de esquerda mais marcada, pertencimento diluído ao longo do tempo em virtude de composições de governo politicamente heterogêneas e uma certa timidez da legenda com pautas historicamente conectadas a legendas progressistas (Samuels, 2004). Ademais, se, normalmente, as pessoas emulam os preceitos políticos divulgados pelas elites, a falta de um ancoramento ideológico pautado em valores justificase pela baixa polarização dos partidos em âmbito nacional (Carlin et al, 2015).

Olhando para as medidas adicionais de controle, verifica-se que nenhum dos preditores se mostrou relevante, exceto a idade. De maneira detida, a expectativa de influência das classes sociais na variável dependente não se confirmou. A denominação religiosa também não apresentou significância estatística: percebe-se a ausência de diferenças entre católicos e evangélicos, quando comparados com crentes de outras religiões, nesse quesito. Os sofisticados politicamente não pensam diferente da maioria da população, ou seja, na balança da identificação ideológica, pesam, principalmente, os componentes afetivos e as preferências dos indivíduos pelo modo de fazer política. Ressalvando-se a questão etária, com os mais velhos associando-se positivamente à direita em ambos os períodos. Por conseguinte, se a idade é a única variável significativa dos preditores, vale investigar se existe alguma diferença geracional atinente aos valores e os fatores simbólicos (figura $7)$.

\footnotetext{
${ }^{27}$ Testou-se a presença de multicolinearidade dos modelos e, em todos, os coeficientes da estimativa do Fator de Variância Inflacionado não ultrapassaram .02, valor bem abaixo do considerado ideal $(<.05)$.
} 
Figura 7: Preditores da identificação ideológica segundo a idade

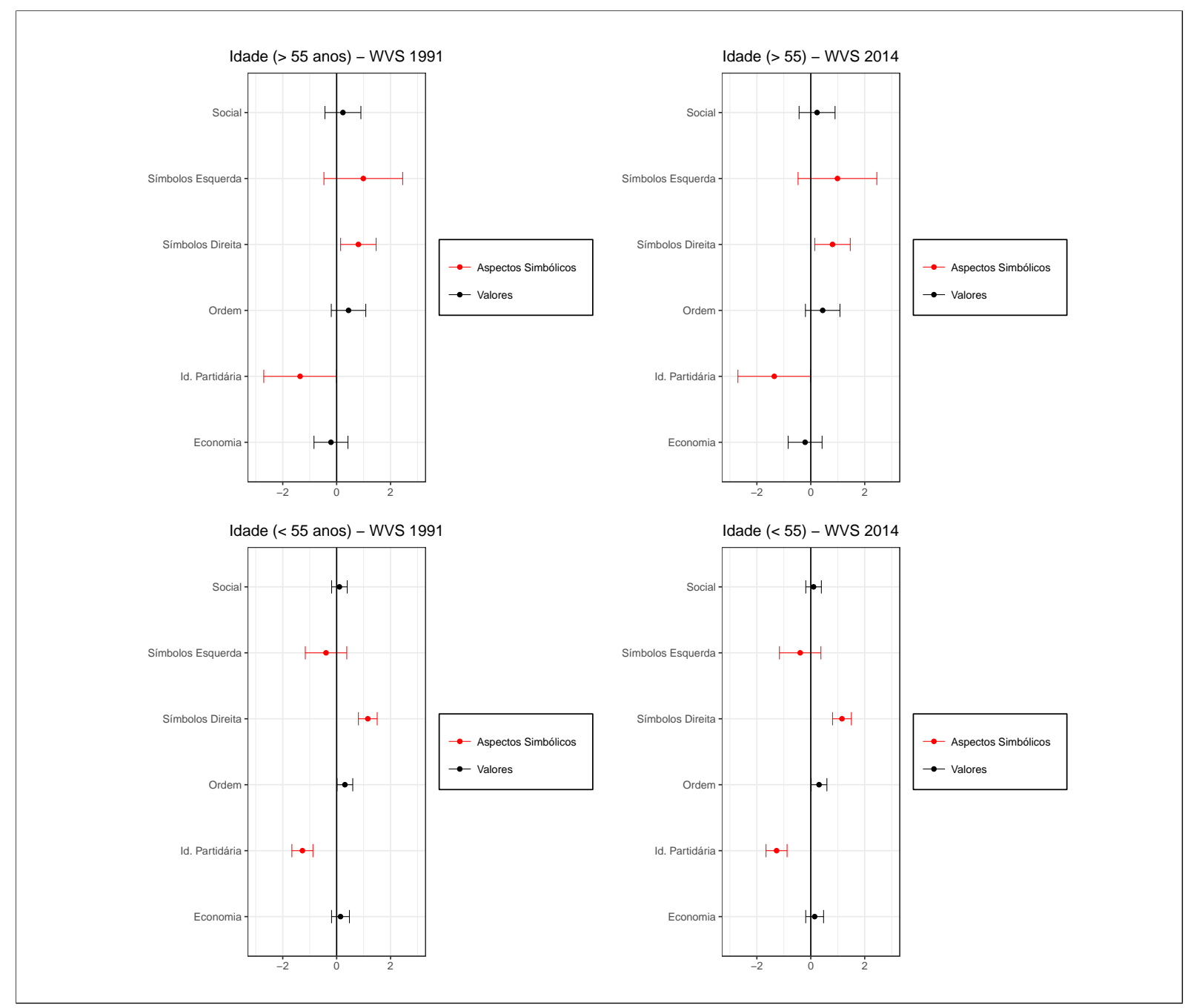

Aqui, foram separados os indivíduos com mais de 55 anos daqueles com menor idade e calculados quatro modelos com as mesmas variáveis das equações anteriores. De antemão, cabe destacar a mudança expressiva nos dois momentos históricos. Em 1991, além de terem maior dificuldade para se posicionar na escala ideológica, os mais velhos adotavam menos os valores distintivos de esquerda e direita, considerando que somente os símbolos de direita têm relevância estatística. Os jovens direitistas lidavam com os aspectos afetivos, assim como com a noção de ordem, a fim de manifestar o vínculo com a variável dependente. O simbolismo, portanto, ocupa lugar central para os dois grupamentos.

Esse panorama muda em 2014, quando as gerações antigas passam, então, a experimentar a expressão cognitiva, e não os conteúdos simbólicos, com o objetivo de declarar 
sua ideologia. Os jovens seguem combinando ambas as matrizes, apesar de confiarem, sobretudo, nos signos sociais. A verificação do princípio geracional reforça a ideia de que os cidadãos com idade acima de 55 anos, em 1991, encontravam alguma dificuldade com os rótulos. Presume-se, assim, que a socialização política em momentos de dissimulação dos condicionantes ideológicos - a ditadura civil-militar - conduziu a um cenário de embaraço dos brasileiros com a metáfora espacial.

\subsection{Valores, símbolos e o contexto histórico}

Os construtos ideológicos são costumeiramente fixados por prismas simbólico-afetivos, constituindo, em certa medida, o sentido da identidade dos indivíduos. Na psicologia política, o reconhecimento do caráter inexorável da associação entre postulados cognitivos e emocionais - isto é, a constatação de que o "sentir" é parte integrante do "saber"tem se tornado paulatinamente indispensável para a compreensão do processamento das informações políticas pelos cidadãos (Thagard, 2006). Assim, a separação das emoções, como estados mentais, dos elementos cognitivos configura um arranjo pouco verificável da estruturação das crenças acerca de temas coletivos. Conceitos, preferências e objetivos sustentam-se em valências afetivas que moldam a coerência das convicções tanto quanto o raciocínio lógico. Longe de serem obstáculos à tomada de decisões particulares, de acordo com o senso comum, conformam componentes indispensáveis da percepção, entendimento e racionalidade humana (Dixon et al., 2013).

Ao longo do presente capítulo, mostrou-se a premência de levar em consideração os ângulos simbólicos e de avaliar de maneira pormenorizada os múltiplos ingredientes valorativos da metáfora espacial, a fim de desanuviar os traços característicos do pertencimento ao contínuo esquerda-direita no Brasil. Os achados afiançam algumas análises pretéritas e jogam luz sobre novos enfoques: a busca da ordem representa o principal conteúdo relacionado ao conflito ideológico no país, ao passo que os condicionantes simbólicos contribuem por impulsionar de vez o pertencimento com os vocábulos.

Por seu turno, a dinâmica situação-oposição, tópico outrora reivindicado pelos cidadãos para se referir à escala unidimensional, parece ter ficado mesmo como uma interpretação datada do início do processo de democratização - embora não tenhamos as 
mesmas medidas para assegurar um enlace definitivo. Nessa direção, a socialização geracional encontra-se igualmente atrelada a esse momento histórico, afinal, foram os mais velhos - sobretudo na década de 1990 - aqueles com maior dificuldade de produzir distinções entre os conceitos. Os sofisticados politicamente, contrariando algumas análises, não exibirem comportamentos distintos do grosso da população, confiando seus julgamentos mais nas expressões emocionais da ideologia.

Tendo isso em vista, a pergunta que fica é se, de fato, o conflito esquerda e direita fornece as pistas mais acertadas para o exame da estruturação das crenças dos indivíduos, já que o alicerce das identificações ideológicas se encontra fincado não em postulados valorativos, mas em pressupostos afetivos. No fim das contas - para ficar com a definição clássica do conceito - o intuito de diagnosticar os edifícios ideológicos mediante ideias e preferências socialmente compartilhadas, utilizadas com a finalidade de compreender, justificar ou desafiar as ordens econômicas, políticas e sociais não estariam sendo subaproveitadas em nome de um construto que capta mais a variante simbólica do que as predileções efetivas das pessoas acerca dos enunciados da agenda pública? Esse é, portanto, o assunto do próximo capítulo. 



\title{
3. As incongruências ideológicas e a multi- dimensionalidade das crenças políticas
}

\author{
Enough already about ideology! \\ - Donald Kinder, Diversity and complexity \\ in American public opinion (1983) .
}

Em ensaio datado dos anos 1980, Donald Kinder (1983) conclamava os cientistas políticos a deixarem de lado os construtos ideológicos e sua virtual influência no comportamento político e eleitoral. O excerto "Basta de ideologia!", em tradução livre, era signatário dos desdobramentos das pesquisas da época e reforçava o caráter aparentemente inócuo de uma formatação normativa das concepções atinentes ao universo político. A literatura inspirada nos trabalhos seminais de Philip Converse (1964) reforçou a ideia de que a vasta maioria da população não se utilizava dos vocábulos liberal e conservative com a intenção de atar os fios deixados soltos pelos conflitos coletivos daqueles anos. Para piorar, quando o fazia, o tear da agenda pública realizado pela "massa" pautava-se em linhas simbólico-afetivas, desconectadas dos valores contidos nos diagnósticos dos especialistas (Connover e Feldman, 1981; Zschirnt, 2011; Ellis e Stimson, 2012).

O super issue (Inglehart e Klingemann, 1976) conectava apenas os pontos dos sofisticados politicamente, uma fatia minoritária do eleitorado, mais engajada e atenta aos ditames do jogo político-partidário. Isso porque a polarização dos partidos Republicano e Democrata se consolidou, sobretudo, a partir da segunda metade do século XX (Layman e Carsey, 2002; Baldassari e Bearman, 2007; Abramowitz e Sanders, 1998; Baldassari e Gelman, 2008; Lelkes, 2016). Se as condutas e visões de mundo dos representados afeiçoam-se à competição intra elites, os sofisticados simplesmente emulavam a estruturação do maquinário criado pelos representantes (Kitscheldt e Hellemans, 1990). Assim sendo, voltando a Kinder, para que insistir, então, em uma composição típico-ideal sustentada apenas por alguns poucos?

Em solo nacional, a análise da ideologia seguiu os postulados desenvolvidos e examinou em que medida os cidadãos eram capazes de estruturar os conflitos sociais aos moldes de um contínuo esquerda-direita. Os quadros institucionais das duas nações eram quase opostos - de um lado, um cenário bipartidário e polarizado; de outro, um multipar- 
tidarismo exacerbado, com coligações diversas, dadas a toda sorte de idiossincrasias -, mas o resultado das interpretações nem tanto: os brasileiros tinham consciência insuficiente dos conteúdos substantivos supostamente atribuídos à metáfora especial, salvo...os politicamente sofisticados (Castro, 1994; Carreirão, 2002). No entanto, conforme enfatizado, a lógica da elaboração unidimensional desse segmento nos EUA era a reprodução informada dos sentidos políticos produzidos pelas lideranças estadunidenses, imersas em um arcabouço de polarização. Na ausência dessa conformação, como no caso do Brasil, qual seria o fundamento, afinal, de uma ordenação cognitiva em somente um eixo ideológico?

Assim, as razões do desconhecimento das categorias costumam se ater justamente à moldura institucional para justificar esta lacuna na população brasileira em relação aos conceitos esquerda e direita. Como resposta a essas pesquisas, argumenta-se em favor de explanações com bases sociológicas e, consequentemente, do postulado da multidimensionalidade das preferências, o qual separa as predileções em eixos distintos. Essa conceitualização favorece um entendimento mais pormenorizado de aspectos significativos da ideologia e auxilia a capturar a forma heterogênea como os indivíduos concebem os conflitos políticos.

O objetivo deste capítulo é, portanto, o exame das formas de estruturação ideológicas e suas implicações para os estudos de comportamento político. Demonstra-se a premência de considerar as opiniões dos cidadãos acerca das matérias públicas sem reduzí-las a uma única dimensão. A existência, portanto, de múltiplos domínios explica o desconforto das pessoas em se identificar com os vocábulos "esquerda" e "direita".

Para desenvolver essa teoria, combinam-se métodos diversos, adequados ao uso de variáveis latentes. As técnicas utilizadas evidenciam o desacordo entre a maneira complexa pela qual normalmente se constituem as convicções políticas e o valor preditivo da escala de autoposicionamento - medida mais empregada em inferências atinentes às inclinações ideológicas. Com efeito, observa-se que o aparente paradoxo decorre da heterogeneidade semântica atribuída pelos cidadãos à formulação unidimensional.

O capítulo, então, divide-se em três seções. Na primeira, são consideradas as pesquisas referentes ao tema da estruturação das crenças dos brasileiros, bem como as formulações que apregoam o desajuste entre o posicionamento ideológico e os conteúdos sustentados de fato pelos indivíduos e os motivos concernentes a esse desacerto. Em se- 
guida, expõe-se os exames empíricos separados em duas partes. Uma focada em análises bivariadas, cuja perspectiva reside na atenção a dinâmicas agregadas e tópicas da incongruência entre duas vertentes da ideologia: a simbólica e a operacional. Outra concentrada em investigações pautadas em regressões multivariadas, a fim de captar os condicionantes diversos das incoerências identitárias. Nos comentários finais, constam sugestões apropriadas a uma operacionalização menos normativa dos preceitos característicos ao universo político.

\subsection{A estrututuração ideológica dos brasileiros}

Os estudos de comportamento político no Brasil também são consensuais quanto ao baixo grau de informação dos cidadãos e ao feitio difuso e pouco estruturado de suas opiniões. Para nomear o fenômeno, Reis (1988) cunhou a expressão "síndrome do Flamengo". Segundo Reis, as preferências ideológicas ou partidárias dos brasileiros não são apoiadas em assuntos propriamente políticos, mas estão ancoradas em imagens obscuras, simplificadas, do cenário em questão. Existe, portanto, uma divisão quase binária baseada em emblemas tais como "povo", "governo", "oposição", "pobres"e "ricos". Essa situação conduziria a política nacional inevitavelmente rumo ao populismo. Conforme o autor:

Assim, no eleitorado popular, em cuja percepção não se integram senão precariamente os diversos aspectos ou dimensões do universo sociopolítico, a opção eleitoral oposicionista parece ligar-se antes ao contraste vagamente apreendido entre o popular e o elitista ("pobres"versus "ricos", "povo"versus "governo"), no qual se traduz uma insatisfação difusa incapaz de articular-se por referência a problemas específicos de qualquer natureza. Por outras palavras: votar na oposição é, para o eleitor em questão, um pouco como 'torcer' por um clube popular de futebol - o Flamengo, digamos, para tomar talvez o mais popular deles. Mas o simplismo mesmo das percepções e imagens em que se baseia essa propensão é um fator a emprestar consistência e estabilidade aos padrões de votação popular. Assentada a poeira das perturbações do quadro partidário, vislumbrados, em seguida a cada rearranjo mais ou menos artificial ou imposto desse quadro, os novos contornos político- 
partidários da contraposição entre "povo"e "elite", volta- se, como no populismo do pré-64 e no MDB de pós-64, ao leito "natural". Temos, assim, uma espécie de "síndrome do Flamengo"que não apenas tende a negar a um regime autoritário como o que controlou o país até 1985 a possibilidade de verdadeira legitimação pela via eleitoral como também faz do populismo, na atualidade brasileira, uma fatalidade, desde que as condições institucionais permitam um jogo político razoavelmente aberto e sensível perante o eleitorado (REIS, 1988, p. 78-79).

A ideia da falta de uma atuação política issue-oriented, isto é, pautada por atores informados sobre as principais agendas coletivas, cuja compreensão levaria ao estabelecimento de um amálgama entre os aspectos mais estáveis desse universo - supostamente aplicável a eleitores de outras searas, sobretudo da Europa Ocidental - logo influenciou uma série de trabalhos de comportamento político. Castro (1994), diretamente inspirada pelos postulados de Reis, levou a cabo a intenção de explicar o comportamento eleitoral segundo o grau de sofisticação dos cidadãos, pois somente uma minoria conseguiria nortear suas decisões guiadas por assuntos políticos, enquanto a grande parcela da população seria desinformada e, consequentemente, não teria opiniões acerca das questões centrais do debate público.

Isto posto, a maioria do eleitorado guiaria seus julgamentos por "imagens políticas"vagas e ponderações atinentes às características pessoais dos candidatos em disputa. Nessa direção, Silveira (1998) pontua que a política atual, fruto de um novo panorama vigente, alicerçada nos veículos midiáticos e no marketing, contribui para a consubstanciação de um eleitor intuitivo e não racional. Para Baquero (Baquero, 1994; Baquero e Castro, 1996), sob a ótica da cultura política, o votante personalista e pragmático marca o estilo predominante dos brasileiros, mais preocupado com critérios de eficiência da gestão pública e com objetos pós-materialistas, tais como qualidade de vida e meio ambiente. Ou seja, sem conteúdos ideológicos fundamentados, incapaz de estabelecer avaliações minimamente coerentes do jogo político.

Relembrando, Singer (1999), mesmo ao defender a incorporação da identificação ideológica à guisa de variável preditiva do comportamento eleitoral, usa instrumental 
semelhante quando pontua o conhecimento abstrato, porém desestruturado dos conceitos esquerda e direita, revelando um emprego intuitivo dessas categorias, caracterizadas tal qual um sentimento ideológico que "[...] permite ao eleitor colocar-se na escala em uma posição que está de acordo com suas inclinações, embora não saiba verbalizar. E a mesma intuição o conduz a situar os candidatos (e os partidos) nessa escala e votar coerentemente" (SINGER, 1999, p. 149).

Diante da impossibilidade, portanto, de fazer inferências corretas a partir de conceitualizações não dominadas pelos pesquisadores, tampouco consentir acerca de conhecimentos intuitivos sustentados somente pela direção do voto, e não pelo conteúdo substantivo daquilo que se trata pelo espectro esquerda e direita, investiga-se aqui os efeitos de possíveis desajustes e o impacto de uma medição multidimensional, mais conectada à pluralidade da hodierna agenda política.

\subsection{Ideologia simbólica ou operacional?}

$\mathrm{Na}$ literatura norte-americana, o "enigma ideológico"(ideology puzzle) tem assumido importância fundamental nos estudos sobre a constituição das crenças dos indivíduos desde os trabalhos de James Stimson (Stimson, 2004; Ellis e Stimson, 2012). O quebracabeça a ser desvendado é o porquê dos cidadãos normalmente se declaram conservadores, embora a maioria prefira um posicionamento à esquerda do espectro político nas questões relativas ao orçamento público. No agregado, portanto, os estadunidenses apoiam políticas redistributivas, a intervenção do Estado na economia e a ação governamental para resolver problemas sociais.

A essas pessoas, Stimson denominou "conservadores em conflito", cuja adoção do rótulo ideológico não acompanha as inclinações sobre as agendas coletivas. Essa categoria, marcada pelos baixos índices de escolaridade, engajamento e renda, e afeita às estruturas da família tradicional, adere ao dístico da direita em virtude de sua importância fora do âmbito da política. Com efeito, os valores tradicionais, muitas vezes calcados em compromissos religiosos, levam um considerável grupamento de eleitores a defender atitudes paradoxais.

Ademais, segundo os argumentos do autor, uma circunstância histórica diversa 
seria o veículo de afastamento do título liberal: notadamente, os episódios ocorridos nos anos 1960 (Ellis e Stimson, 2012). Na época, Lyndon Johnson, então presidente dos Estados Unidos, lançou o programa intitulado Great Society, uma extensão radical dos desígnios de outro projeto famoso, o New Deal - do antigo mandatário, Franklyn Roosevelt. A proposta de Johnson ia além do "cidadão comum", de classe média convencional, trazendo benefícios e, sobretudo, o aumento da capacidade de articulação das camadas populares. O "programa dos pobres", como ficou conhecido, permitia que os desvalidos se organizassem de acordo com sua própria conveniência, ao dirigir quantias do dinheiro federal para áreas urbanas, configurando uma forma de governo alicerçada em conselhos populares e na dispensa de funcionários públicos eleitos, com a "máxima participação factível"dos mais necessitados.

Todavia, o aumento do horizonte de expectativas dos populares nos guetos urbanos foi entendido por parcelas da comunidade norte-americana como a motivação que impulsionou os motins característicos da década de 1960. O termo liberal, frequentemente destacado por Johnson em sua autodescrição, passou a ser associado em seu caráter simbólico à desordem e ao distúrbio social. Logo, um dos lados do espectro estaria vinculado a um evento que, avaliado negativamente pela maioria da sociedade, se tornaria um obstáculo posterior ao vínculo com o flanco à esquerda do campo político norte-americano.

Nesse sentido, o autor, a fim de isolar o posicionamento ideológico declarado das inclinações políticas estruturadas pelos indivíduos, criou uma diferenciação entre a ideologia associada à autoclassificação - a vertente simbólica - e outra ligada ao conjunto de princípios atinentes ao papel dos governantes - a vertente operacional. Na primeira, como vimos no capítulo 2 , os cidadãos são instados a se posicionar no tradicional contínuo esquerda-direita, independente de seu real significado. Afora os altos indicadores de desconhecimento, aqui como nas obras de Stimson, notamos uma localização na escala baseada mais em componentes afetivos, fincados em identidades grupais, do que em aspectos valorativos (Conover e Feldman, 1981; Zschirnt, 2011). Na segunda, percebe-se como as concepções políticas vêm à tona em escolhas objetivas, indicando que as disposições gerais constituem escolhas particulares - ou seja, o ordenamento abstrato das preferências se dá a partir de acomodações não observadas em alguns casos, portanto latentes, nas quais os elementos moldam as escolhas entre alternativas concretas em domínios específicos 
(Zaller, 1992).

O pano de fundo dessa elaboração repousa na ideia de possíveis desacordos entre as duas ideologias e de fontes de dissonância fundamentadas em prismas distintos. Ao avançar no tema, Popp e Rudolph (2011) afirmam que enquanto a ideologia operacional tende a reduzir a incongruência entre as posições e os conceitos espaciais; a ideologia simbólica, pautada em postulados identitários, usualmente desempenha um papel de distorção, pois o pertencimento dos indivíduos a determinados grupos sociais pode exercer uma atribuição sobreposta ao sistema cognitivo de crenças dos cidadãos.

As críticas mais contundentes aos trabalhos de Stimson enfatizam o entendimento de que os cidadãos organizam as informações políticas conforme dimensões destacadas, independentes entre si (Popp e Rudolph, 2011; Claasen et al, 2014). Dessa maneira, as pessoas evitam os vocábulos esquerda e direita em virtude do caráter reducionista de seu escopo fundamental, uma vez que podemos compatibilizar tanto tendências progressistas quanto conservadoras em nossas visões de mundo. Portanto, além das identidades "extrapolíticas", outro entrave à assimilação real das preferências é a manifestação de saliências atribuídas a cada dimensão ideológica.

\subsection{Pensando de maneira multidimensional}

Grosso modo, os trabalhos a respeito da incapacidade dos brasileiros de lidar com o binômio esquerda-direita têm no arcabouço institucional a resposta-chave para a confusão conceitual. Os fatores catalogados são vários, como, por exemplo, a ausência de um sistema político estruturado (Ames e Smith, 2010); a incongruência entre os programas dos partidos e sua efetiva atuação parlamentar (Tarouco e Madeira, 2013); as coalizões de legendas de diferentes matrizes ideológicas (Carreirão, 2007; Meneguello, 2010); o sistema eleitoral de lista aberta e o consequente predomínio das personalidades políticas (Nicolau 2006; Braga e Pimentel, 2011); os constantes "troca-trocas" partidários pelos representantes (Ferreira, Batista e Stabile, 2008); e a ausência de uma polarização programática (Clinton et al, 2015).

A noção subjacente a todas essas obras é a de que o comportamento e as visões de mundo dos cidadãos são moldados usualmente pela competição intra-elites, afetando 
os primeiros ao ativar clivagens específicas e fornecer as informações concernentes aos termos em disputa. Dado que os partidos são os instrumentos mais importantes para a publicização das ideologias, o Brasil não ofereceria um solo muito fértil para a proliferação desse enfrentamento, até para os mais sofisticados politicamente.

A despeito da configuração institucional ter de fato um peso considerável sobre o comportamento político dos eleitores, a imprecisão conceitual não encontra aconchego somente em território nacional. Como foi dito, pesquisas análogas na Europa e nos Estados Unidos normalmente chegam à mesma conclusão da falta de clareza quanto aos vocábulos (Kitscheldt e Hellemans, 1990; Feldman e Johnston, 2014; Freire, 2015). Se, portanto, o desconhecimento e a heterogeneidade são a tônica em diferentes países, a justificativa institucional perde sua força explicativa.

Nessa direção, acredita-se que uma explanação de caráter propriamente sociológico satisfaz de modo mais convincente a questão da inabilidade dos cidadãos em utilizar as duas concepções. Isso porque as transformações societais, ocorridas sobretudo após a Segunda Guerra Mundial, trouxeram consigo formas radicalmente novas assumidas pelo conflito social (Laclau, 1986; McAddams et al, 2005; Inglehart, 2007; Della Porta e Diani, 2009). A gramática das contendas - que antes assumia uma denotação mais vinculada às relações de produção e colocava em voga demandas pela redução da jornada de trabalho, o acesso dos trabalhadores aos bens de consumo e o aumento dos salários - foi então ampliada devido a um processo de complexificação da sociedade, provocado, especialmente, pelo acesso acrescido dos cidadãos a níveis educacionais mais altos e a inclusão de outros atores - como as mulheres e os negros - ao mercado de trabalho formal.

Os issues que eclodiram nos 1960 e 1970 - o aborto, a legalização das drogas, a luta por direitos iguais - e os novos movimentos sociais - feministas, ambientais, indígenas, LGBTT somente podem ser parcialmente encaixados na dimensão econômica e da luta de classes. O redesenho das linhas conflitivas abarca agora orientações autonomistas, de autoexpressão e de defesa de estilos de vida alternativos. Em suma, as reivindicações por medidas de redistribuição de recursos e a luta de classes continuam importantes, mas são insuficientes para descrever os antagonismos sociais de hoje e dividem espaço com questões quase invisíveis a gerações anteriores.

A expansão da agenda política, entretanto, foi paulatinamente acomodada à tra- 
dicional divisão espacial (Inglehart, 2007). Isto posto, a elasticidade conceitual do espectro esquerda-direita logo serviu de guarida para as novas pautas e padrões de competição. Contudo, relatamos metade da história dos grupamentos ideológicos contemporâneos quando postulamos que a esquerda está relacionada à distribuição mais justa dos salários e das riquezas produzidas pela sociedade - admitindo a intervenção do Estado para alcançar seus desígnios -, à preocupação com as causas ambientais, faz oposição à energia nuclear e às armas, e na questão dos costumes representa posturas liberais; enquanto a direita é mais afeita às desigualdades econômicas e afinada com valores tradicionais, os princípios de autoridade, ordem e manutenção do status quo.

A metade restante desse universo, entretanto, pode combinar preceitos opostos ao longo de dimensões conflitivas diferentes: um mesmo indivíduo é capaz de ser liberal no tocante aos costumes sociais e conservador a respeito de postulados econômicos. Em relação a esse item, Swedlow (2008) adverte sobre a lógica que perpassa ambas. Para o autor, ela se sustenta em predicados dissonantes referentes à regulação. Na área econômica, a ordenação governamental serve para diminuir a desigualdade ao proteger os vulneráveis; enquanto no campo social, a intervenção acarreta em aumento da iniquidade, uma vez que a ingerência estatal privilegia determinados tipos de comportamento em detrimento de outros.

Segundo a visão unidimensional do espectro, as diferentes combinações desses preceitos frequentemente se caracterizam por pressupostos negativos, como a falta de sofisticação, a "inocência ideológica" ou a ausência de constrição das crenças políticas - para ficar na literatura influenciada por Converse (1964). Por seu turno, uma série de pesquisadores tem argumentado em prol da necessidade de se examinar mais de uma dimensão para iluminar a estrutura de atitudes políticas (Conover e Feldman, 1981; Kerlinger, 1984; Peffley e Hurwitz, 1985; Heath, Evans e Martin, 1994; Evans, Heath e Lalljee, 1996; Ashton et al., 2005; Treier e Hillygus, 2009; Baldassari e Goldberg, 2014, Carmines, 2015). Conforme esses autores, a diferença das duas categorias não se dá em termos bipolares, mas em torno de crenças relativamente distintas, assentadas em referenciais divergentes.

Com efeito, investigações baseadas em pesquisas de opinião e operacionalizadas a partir de técnicas de análise fatorial comprovam que a consideração dos conceitos esquerda-direita se atém a diferentes variáveis latentes e que essas são ao menos inde- 
pendentes entre si (Jost, 2009; Feldman e Johnston, 2013). Ou seja, atitudes referentes a questões sociais ou culturais designam distinções fatoriais de matérias econômicas, logo, justificam apreciações de caráter ortogonal. As pesquisas mostram, ainda, que ao ajustar suas preferências a domínios distintos, os respondentes tendem a se dizer "moderados", com o objetivo de escapar do espectro esquerda-direita (Alvarez e Brehm, 1995; Treier e Hillygus, 2009).

Como um produto crítico da multidimensionalidade, a saliência de algumas crenças específicas varia entre os indivíduos, criando quadros de referência dessemelhantes pelos quais são compreendidos os rótulos em questão. Em trabalho recente, Feldman e Johnston (2014) reforçam essa perspectiva: "avaliações empíricas que não levam em consideração a complexidade desses significados e dessa estrutura falham em determinar aspectos importantes dos determinantes ideológicos e suas consequências para a política" (tradução livre) (Idem, 2014: 338).

Não obstante, a combinação conceitual entre inconsistência ideológica e multidimensionalidade se afasta da ideia de ambivalência, presente na literatura nacional com o trabalho de Rennó e Ames (2014). Para os autores,

\footnotetext{
[...] ambivalência ocorre quando o indivíduo tem posições conflituosas acerca de um objeto. Isso é causado por atenção e interesse por aquele objeto, e não por distanciamento e indiferença. Indiferença é a ausência de posição sobre um objeto e é idêntica a uma atitude de neutralidade sobre algo, em que o indivíduo simplesmente não tem posição definida sobre algo. Assim, indiferença pode ser vista como a ausência de uma atitude por desinteresse acerca do tema (Rennó e Ames, 2014: 06).
}

Analogamente, a inconsistência ideológica não é causada pela desatenção em relação aos assuntos políticos. Contudo, a ambivalência pleiteia a noção de inclinações estruturadas sobre temas específicos, aspecto contestado no capítulo anterior. Como vimos, o posicionamento no espectro esquerda-direita salienta uma disposição abstrata, definida muitas vezes por vinculações simbólico-afetivas, e não por princípios sedimentados. 


\subsection{A análise dimensional}

Saindo dos conceitos para os indicadores, com o intuito de ressaltar que a unidimensionalidade do contínuo ideológico mostra-se pouco factível para descrever a estruturação das crenças políticas dos cidadãos, põe-se em destaque um conjunto de perguntas utilizadas no capítulo 2 e relacionadas às dimensões destacadas. Recordando, nos WVS, três questões foram selecionadas para representar a dimensão econômica: ponderações acerca da igualdade salarial, atuação do Estado versus mercado e aceitação da ideia que competição é um bem a ser estimulado. Mensurou-se a dimensão social mediante as inclinações sobre a homossexualidade, o aborto, o divórcio e o sexo antes do casamento. Por último, o consentimento com manifestações públicas, greves e protestos marcam o enfoque na participação política.

Como preditores dessas dimensões, alguns fatores demográficos: idade, sexo, renda, sofisticação política e religiosidade ${ }^{28}$. As duas últimas são medidas compósitas, montadas com base na soma de diferentes itens. Religiosidade foi tratada como um item só - sem separar os diferentes grupos religiosos (católicos, evangélicos, etc) - porque alguns estudos anteriores, como o de Bohn (2004), revelam a inexistência de uma diversidade significativa de crenças entre os grupamentos religiosos. Ademais, a diminuta proporção de evangélicos na edição de 1991 (em torno de 3\%) dificulta a comparação do preditor com a versão de $2014^{29}$

A análise é baseada em modelos apropriados ao uso de variáveis latentes, a Análise Fatorial Confirmatória (AFC) e a Teoria de Resposta ao Item (TRI). No caso da AFC, os parâmetros foram estimados via mínimos quadrados ponderados com erros-padrão robustos. Tendo em vista que a maioria dos itens é categórica, adota-se funções ordenadas e probit nos modelos de análises fatoriais. Por fim, os fatores latentes possuem uma escala com variância de 1, e os valores mais elevados indicam orientações conservadoras nas respectivas dimensões. Na esfera econômica, "ser conservador"significa apoiar os mecanismo pró-mercado; na social, dar suporte a posições contrárias às liberdades comportamentais; e, quanto à ordem, endossar um discurso de oposição às manifestações populares.

\footnotetext{
${ }^{28} \mathrm{~A}$ formulação exata das perguntas selecionadas aparece no apêndice, localizado no final do texto.

${ }^{29}$ Foram criadas cinco bases de dados a partir de imputação múltipla. Todos os estimadores foram obtidos mediante o efeito médio de cada uma das bases criadas (King et al., 2001).
} 
As medidas de ajuste encontram-se na Tabela 10. Em todos os anos, os postulados multidimensionais levam vantagem. Senão vejamos, os ajustes unidimensionais aparecem com valores de CFI $(0,65 ; 0,61$ e 0,73$)$ bem abaixo do mínimo aceito $(0,90)$, e de RMSEA acima de $0,10(0,14 ; 0,15$ e 0,16) - quando o desejável seriam dígitos menores que 0,05; ao passo que os modelos com três dimensões apresentam configurações bastante satisfatórias (CFI de 0,97; 0,95 e 0,98; RMSEA de 0,03; 0,04 e 0,03) ${ }^{30}$.

Tabela 10: Medidas de ajuste comparadas

\begin{tabular}{lcc}
\hline & WVS 1991 & WVS 2014 \\
\hline CFI (unidimensional) & .65 & .73 \\
CFI (multidimensional) & .97 & .98 \\
RMSEA (unidimensional) & .14 & .16 \\
RMSEA (multidimensional) & .03 & .03 \\
N & 1782 & 1486 \\
\hline Nota: CFI = Comparative Fit Index; RMSEA $=$ Root \\
Mean Squared Error of Approximation.
\end{tabular}

A Teoria de Resposta ao Item é outra forma de procurar correspondência entre os modelos latentes e suas manifestações ${ }^{31}$. Assim como a AFC, a TRI usa caracterizações latentes de indivíduos e de itens como preditores de respostas observadas e assume que as escalas são contínuas (Ayala, 2008). A TRI, no entanto, aplica-se normalmente a dados categóricos, ou seja, com respostas binárias ou politômicas. No seu emprego dicotômico, ao valor 0 atribui-se a ausência de alguma característica - ou, no caso de testes de proficiência, uma resposta incorreta - e ao valor 1 o justo oposto. Os modelos podem, então, ser compostos de um, dois ou três parâmetros - dependendo do grau de especificidade trabalhado. Tipicamente, a abordagem de dois parâmetros, a mais comum na ciência

\footnotetext{
${ }^{30}$ Os coeficientes padronizados da AFC aparecem no apêndice

${ }^{31}$ A TRI foi originalmente concebida como um meio de estimar a habilidade dos indivíduos - um traço latente, não observado de forma direta -, em respostas a testes de questões categóricas (Ayala, 2013). Mais empregada na psicologia e na área de Educação, a TRI na ciência política aparece como substrato de artigos que tentam analisar o ponto ideal do posicionamento de legisladores (Jackman, 2001; Zucco Jr., 2001) e de membros da Suprema Corte Norte-Americana (Martin e Quinn, 2002), o conhecimento politico (Delli Carpini e Keeter, 1993) e atitudes ideológicas (Treier E Hillygus, 2009).
} 
política, é traduzida pela expressão:

$$
\operatorname{Pr}\left(y_{j k}\right)=\operatorname{logit}^{-1}\left(\alpha_{j(i)-\beta_{k(i)}}\right)^{32}
$$

- em que $j$ representa os indivíduos submetidos a testes com $k$ itens, sendo $y_{j k}=1$ quando a resposta apresenta uma configuração correta;

- em que $j$ o parâmetro $\alpha_{j}$ indica a habilidade de uma pessoa $j$;

- $\beta$ a dificuldade da questão $k$.

Em contraste com a AFC, os modelos de IRT incluem um parâmetro de dificuldade $\alpha$, além do parâmetro de discriminação $\beta_{j}$. Consequentemente, podemos fazer inferências sobre a variável latente $\xi$ ao mesmo tempo em que avaliamos $\beta$ e $\alpha$. Na condição politômica, normalmente composta por escalas ordinais (likert scale) que vão das categorias de desacordo à concordância a respeito de um determinado tema ${ }^{33}$, temos a inclusão de limiares $\tau_{h}$ (thresholds) na equação, assumindo a separação das gradações.

\footnotetext{
${ }^{32}$ Como nem todas as pessoas necessitam receber cada um dos itens, é conveniente indexar as respostas individuais com $i=1, \ldots, n$, demarcando a associação com pessoas $j(i)$ e questões $k(i)$ (Bafumi, et al., 2005).

${ }^{33}$ Além do modelo politômico baseado em escalas ordinais, a TRI também apresenta uma opção voltada para a avaliação de créditos parciais (mais comum em trabalhos atinentes à área da educação), orientada para captar situações em que o respondente "acerta" pela menos uma parte da resposta (Ayala, 2008).
} 
Este modelo pode ser descrito pela notação ${ }^{34}$ :

$$
\begin{array}{r}
\operatorname{Pr}\left(y_{i}>1\right)=\operatorname{logit}^{-1}\left(\gamma_{k(i)}\left(\alpha_{j(i)-\beta_{k(i)}}\right)\right. \\
\operatorname{Pr}\left(y_{i}>2\right)=\operatorname{logit}^{-1}\left(\gamma_{k(i)}\left(\alpha_{j(i)-\beta_{k(i)}}\right)-c_{2}\right) \\
\ldots \\
\operatorname{Pr}\left(y_{i}>1\right)=\operatorname{logit}^{-1}\left(\gamma_{k(i)}\left(\alpha_{j(i)-\beta_{k(i)}}\right)-c-1\right) \\
\ldots \\
\operatorname{Pr}\left(y_{i}>L-1\right)=\operatorname{logit}^{-1}\left(\gamma_{k(i)}\left(\alpha_{j(i)-\beta_{k(i)}}\right)-c_{L}-1\right)
\end{array}
$$

Em que $y_{i}$ é a probabilidade do respondente $j$ escolher uma das opções de resposta das categorias $l$ do item $k$. Como exemplo aplicado ao presente capítulo, podemos pensar em um modelo onde o parâmetro $\alpha_{j}$ representa o conservadorismo de cada respondente e $\beta_{k}$, de maneira análoga, dos temas sugeridos nos questionários. Dado que determinados questionamentos recebem um número maior de réplicas reacionárias - caso da legalização do aborto, que costuma ter menos entusiastas se cotejada à questão do divórcio -, o parâmetro $\beta_{k}$ serve para controlar essa taxa de variação entre os itens.

Ademais, conquanto os itens provêm níveis diferentes de informações relevantes sobre a estruturação latente da ideologia, estes podem ser adicionados aos moldes de estimadores de discriminação para os itens, indicando o quanto eles conseguem diferenciar entre cidadãos mais ou menos conservadores. Por conseguinte, enquanto valores positivos indicam a saliência dos temas e ajudam a separar os indivíduos investigados; valores próximos a zero assinalam a similaridade das respostas. Todavia, considerando-se que o interesse da medição é a estruturação das crenças políticas, as características das questões não serão organizadas em gráficos por problemas de espaço.

Pode-se elencar ao menos duas vantagens principais da TRI em relação à AFC: 1) nem todos os entrevistados precisam receber itens idênticos, o que significa que não precisamos descartar as informações sobre um indivíduo quando o mesmo não omitiu opinião a respeito de um tema; 2) a modalidade ordenada do modelo apresenta resultados mais consistentes com questões politômicas se cotejada com a AFC (Treier e Jackman,

\footnotetext{
${ }^{34} \mathrm{O}$ modelo assume a mesma notação descrita por Bafumi et al., embora tenha sido modificado para explicitar uma formatação com respostas ordinais.
} 
2008; Treier e Hillygus, 2009).

Na tabela 11 ilustramos essa tendência com as perguntas atinentes aos itens destacados com escalas unidimensionais e multidimensionais:

Tabela 11: Análise dimensional baseada na TRI (WVS 1991 e 2014)

\begin{tabular}{|c|c|c|c|c|}
\hline \multicolumn{5}{|c|}{ Painel A } \\
\hline \multicolumn{2}{|c|}{ Modelo unidimensional } & \multicolumn{3}{|c|}{ Modelo multidimensional } \\
\hline & & Econômica & Social & Ordem \\
\hline Igualdade salários & $-0,08$ & 0,59 & 0,02 & $-0,01$ \\
\hline Estado X mercado & $-0,14$ & 0,60 & -0.03 & $-0,02$ \\
\hline Responsabilidade governo & 0,08 & 0,64 & 0,01 & 0,01 \\
\hline Sexo menores & 0,68 & 0,02 & 0,66 & 0,08 \\
\hline Homossexualidade & 0,62 & $-0,07$ & 0,65 & 0,05 \\
\hline Aborto & 0,61 & 0,00 & 0,74 & $-0,05$ \\
\hline Divórcio & 0,58 & 0,02 & 0.70 & $-0,04$ \\
\hline Boicotes & $-0,28$ & -0.04 & $-0,05$ & 0,70 \\
\hline Manifestações & $-0,26$ & 0,03 & 0,02 & 0,84 \\
\hline Greves & $-0,25$ & $-0,02$ & 0,00 & 0,72 \\
\hline \multicolumn{5}{|c|}{ Painel B } \\
\hline \multirow{2}{*}{\multicolumn{2}{|c|}{ Modelo unidimensional }} & \multicolumn{3}{|c|}{ Modelo multidimensional } \\
\hline & & Econômica & Social & Ordem \\
\hline Igualdade salários & 0,02 & $-0,06$ & $-0,01$ & 0,52 \\
\hline Estado X mercado & 0,00 & 0,00 & $-0,02$ & 0,64 \\
\hline Responsabilidade governo & 0,11 & 0,01 & 0,10 & 0,46 \\
\hline Sexo menores & 0,28 & 0,81 & 0,00 & $-0,03$ \\
\hline Homossexualidade & 0,25 & 0,62 & 0.043 & 0,06 \\
\hline Aborto & 0,28 & 0,43 & 0,12 & 0,13 \\
\hline Divórcio & 0,24 & 0,80 & $-0,03$ & $-0,01$ \\
\hline Boicotes & 0,84 & 0,02 & 0,86 & 0,00 \\
\hline Manifestações & 0,79 & $-0,03$ & 0,77 & $-0,01$ \\
\hline Greves & 0,69 & $-0,07$ & 0,66 & $-0,04$ \\
\hline
\end{tabular}

Fonte: Elaboração própria. Correlação entre as dimensões no WVS 1991: eco \& soc $(0,14) /$ eco \& ordem $(0,05)$ / soc \& ordem $(0,25) /$. Correlação entre as dimensões no WVS 2014: eco \& soc $(-0,25) /$ eco \& ordem $(0,08)$ / soc \& ordem $(-0,03)$. 
Seguindo a mesma trilha, a comparação dos preditores da variável ideológica merece algumas considerações. Por ora, comecemos com a ideia do contínuo unidimensional, representada pela escala de autoposicionamento. Nessa parte, ela será a variável dependente, configurada de forma que os maiores valores estejam ligados a inclinações à direita. Estima-se, assim, uma regressão linear com variáveis independentes de caráter demográfico: idade, sofisticação política, sexo, renda e religiosidade. Os coeficientes estão dispostos na tabela 12 .

Tabela 12: Regressão linear dos preditores da escala de autoposicionamento

\begin{tabular}{lcc}
\hline & WVS 1991 & WVS 2014 \\
\hline Idade & $.05(.00)^{*}$ & $.01(.00)^{*}$ \\
Sexo (feminino) & $.00(.00)$ & $.00(.00)$ \\
Renda & $-.05(.03)$ & $-.02(.03)$ \\
Sofisticação & $-.12(.03)^{*}$ & $-.11(.03)^{*}$ \\
Religiosidade & $.01(.00)^{*}$ & $.00(.00)^{*}$ \\
$\mathrm{R} 2$ & .09 & .03 \\
$\mathrm{~N}$ & 1782 & 1486 \\
\hline
\end{tabular}

Nota: Significância estatística a .05.

Os valores reportados explicitam o quanto cada questão pertence a um escore latente. Assim, se um item não ajuda a discernir os respondentes, os parâmetros de discriminação serão próximos a 0. A grande variação dos parâmetros em dimensões distintas nos anos expostos sugere a vantagem do composto multidimensional - aspecto corroborado pelas medidas comparativas AIC e BIC, sempre menores no primeiro caso. Os blocos de perguntas agrupam-se claramente em colunas distintas, conforme especulado ao longo do capítulo. Na escala unidimensional, por seu turno, notamos como somente uma parcela dos itens apresenta valores significativos $(>0,40)$.

Apesar da superioridade do modelo multidimensional, optou-se por um ajuste que autoriza a correlação entre as dimensões em vez de um arquétipo ortogonal. No entanto, as baixas de correlação dos fatores $(<0,30)$ asseguram a validade do ajuste, atestando o suposto de independência dos três âmbitos.

Nos WVS 1991 e 2014, os efeitos dos preditores são semelhantes. Pessoas com idade avançada e os mais religiosos tendem a se identificar como direitistas; os sofisticados, ao 
contrário, evitam essa categorização. Renda e sexo não possuem associação significativa em nenhum dos modelos.

Levando em conta os postulados teóricos deste capítulo, entretanto, cumpre fazer a presente indagação: afinal, os mais velhos e os religiosos são conservadores em relação a quê? E aqueles com altos graus de educação são progressistas em termos econômicos, sociais ou no modo de fazer política? Se tivermos em vista, portanto, mais de uma dimensão, o quadro logo muda de figura.

Nos paradigmas multidimensionais, contudo, estimam-se Modelos de Equação Estruturais (MEE). Os MEE, uma combinação de psicometria com análises de trilha (path analysis), permitem a inclusão de indicadores múltiplos e variáveis latentes na equação (Bollen, 1989) ${ }^{35}$ A vantagem dessa especificação é que ela autoriza o exame da associação das escalas criadas com preditores distintos, sem deixar de lado os erros de mensuração das variáveis latentes (Kaplan, 2008). Tipicamente, o modelo constitui-se de duas etapas: na primeira, aos moldes de uma análise fatorial confirmatória, estimam-se as relações dos indicadores e as escalas latentes (variáveis endógenas); na segunda, depois de consolidadas as escalas, operacionalizadas conforme distribuições contínuas, são estipuladas as relações destas com outros componentes exógenos - no caso, regressores sociodemográficos ${ }^{36}$.

A figura 8 contém a análise de trilha do MEE ponderado, com três construtos latentes e dezesseis indicadores. Seguindo a mesma convenção das análises fatoriais, as variáveis observáveis estão dentro dos retângulos, enquanto as dimensões latentes encontram-se envoltas por círculos. Setas únicas indicam a influência de um componente sobre o outro e setas duplas assinalam a covariância entre as variáveis conectadas.

Como pode ser notado, a equação presente na tabela 8, foi expandida para incorporar os preditores idade, sexo (feminino), renda, sofisticação e religiosidade. Quanto à variável dependente, coeficientes mais elevados associam-se a tendências conservadoras.

\footnotetext{
${ }^{35}$ Mais conhecidos na psicologia e na sociologia, os MEE são pouco utilizados na ciência política, apesar das vantagens proporcionadas pela consideração dos termos de erro. Exceções podem ser feitas a alguns trabalhos que têm como foco a identificação partidária. Dentre eles: Palmquist e Green (1992) e Carsey e Layman (2006).

36 Pela conformação dos vínculos entre as variáveis, com uma escala latente como variável dependente, a técnica também pode ser referida por Modelo de Múltiplos Indicadores e Múltiplas Causas (MMIMC).
} 
Figura 8: Inconsistência entre as ideologias simbólica e operacional

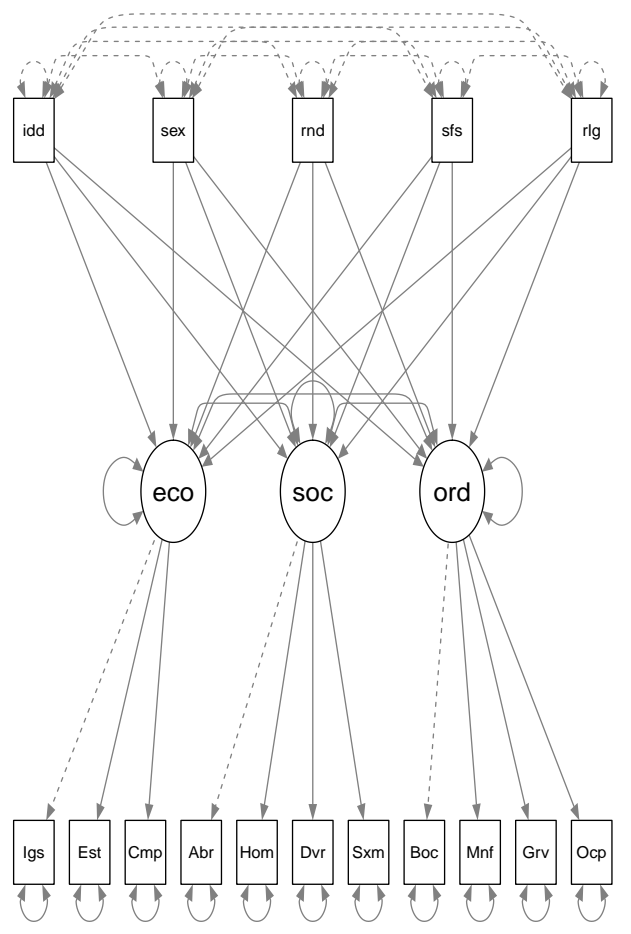

Novamente, os valores de RMSEA $(<0,05)$ e CFI $(>0,95)$ demonstram o bom ajuste do modelo aos dados e a baixa correlação dos fatores expressa a independência das dimensões.

De imediato, constata-se a primeira grande diferença: idade correlaciona-se negativamente com a dimensão econômica, mas positivamente com as outras duas dimensões nos WVS 1991 e 2014 - embora não alcance significância estatística no primeiro item. Em outras palavras, os mais velhos preferem a regulamentação estatal em todas as áreas consideradas. As mulheres, por sua vez, aparecem no WVS 1991 como mais estatistas economicamente que os homens; e, no WVS 2014, vinculam-se a meios conservadores de conduzir a política.

A edição de 1991 mostra que os mais ricos costumam se liberais economicamente, mas progressistas nas esferas dos costumes e menos autoritários politicamente. Ainda em 1991, os sofisticados são afeitos aos ditames do mercado, aos direitos sociais e políticos; em 2014, o mesmo ocorre com as duas últimas dimensões. Nos anos pesquisados, a religiosidade não assume um papel relevante no setor econômico, todavia, ocupa lugar central no conservadorismo social em ambos os WVS e no conservadorismo político na 
edição de 2014.

Em síntese, em todas as bases de dados, os modelos multidimensionais exibem ajustes superiores. Por todos os parâmetros investigados, a descrição, com somente um fator latente, expressa uma acomodação pobre, limitada e, às vezes, até enganosa dos elementos ponderados. Isso fica ainda mais evidente quando apurados os determinantes demográficos das variáveis latentes: se, por um lado, alguns efeitos perdem completamente seus significados - casos de renda e sexo; por outro, as associações dos regressores exprimem nuances mal-acabadas - exemplo da idade, vinculada de maneira genérica à direita do contínuo ideológico no tratamento unidimensional, porém com direções associativas divergentes nos três planos apreciados.

\subsubsection{Sofisticação, faixa etária e ideologia}

O nexo entre sofisticação política, faixa etária e ideologia é motivo de controvérsias na literatura nacional e internacional, conforme sublinhado no capítulo 2 (Carreirão, 2002; Tarouco e Madeira, 2013; Bonifácio et al., 2014; Oliveira e Turgeon, 2015). Em atenção ao debate, a comparação entre ambas passa a ser o foco da presente seção. Afinal, existe a possibilidade que os sofisticados e os mais velhos compreendam melhor os conceitos esquerda e direita e pensem unidimensionalmente. Para tanto, opõe-se a estrutura latente desses grupos, novamente com análises fatoriais. Sofisticação guarda o mesmo formato anterior. Na faixa etária, separa-se os menores e os maiores de 55 anos no WVS. Lembrando a disposição binária de todas.

As medidas de ajuste seguindo os respectivos critérios estão nas tabelas 13 e 14 . Outra vez, os modelos unidimensionais mostram ajustes inadequados nos dois grupos, sem nenhuma grande diferença. Nenhum dos CFIs chega a ultrapassar o valor de 0,70 e os RMSEAs ficam por volta de 0,13 e 0,21. Mesmo abaixo das especificações aceitas, não se pode verificar sequer uma ligeira variação em prol dos sofisticados ou dos mais velhos. Enquanto isso, a perspectiva com três fatores aponta regularmente para resultados dentro dos limites aceitáveis. Os piores CFI e RMSEA registram 0,95 e 0,04, nesta ordem. Os padrões de correlação, de forma análoga, não expressam significâncias consideráveis entre as dimensões, todas inferiores a 0,30 ( $\mathrm{p}<0,05)$, corroborando a tese da independência 
dos fatores latentes ponderados.

Tabela 13: Medidas comparadas de ajuste segundo a sofisticação política

\begin{tabular}{lcc}
\hline & WVS 1991 & WVS 2014 \\
\hline Menos sofisticados: & & \\
CFI (unidimensional) & .62 & .72 \\
CFI (multidimensional) & .97 & .99 \\
RMSEA (unidimensional) & .13 & .15 \\
RMSEA (multidimensional) & .03 & .02 \\
R eco \& soc/ eco \& pp/ soc \& eco & $-.05 / 00 /-.19$ & $.01 / .02 /-.07$ \\
\hline & WVS 1991 & WVS 2014 \\
\hline Mais sofisticados: & .57 & .70 \\
CFI (unidimensional) & .98 & .98 \\
CFI (multidimensional) & .21 & .18 \\
RMSEA (unidimensional) & .04 & .04 \\
RMSEA (multidimensional) & $.15 /-.10 /-.22$ & $-.08 / .06 /-.11$ \\
R eco \& soc/ eco \& pp/ soc \& eco & & \\
\hline Nota: CFI = Comparative Fit Index; & RMSEA $=$ & Root Mean \\
Squared Error of Approximation; R $=$ Correlação entre os fa- \\
tores latentes.
\end{tabular}

As evidências salientadas, portanto, não permitem distinções dos grupamentos selecionados. Esses achados acompanham, parcialmente, os trabalhos de Bonifácio et al. (2014) e Oliveira e Turgeon (2015) e respondem aos questionamentos propostos por Tarouco e Madeira (2013). Contudo, fornecem uma resolução alternativa à indagação sobre os motivos do desconhecimento das categorias ideológicas. De modo geral, as pessoas organizam suas crenças políticas em âmbitos separados - e essa é possivelmente a razão pela qual evitam se classificar como esquerdistas e direitas ou o fazem por meios dessemelhantes. 
Tabela 14: Medidas comparadas de ajuste segundo a idade

\begin{tabular}{lcc}
\hline & WVS 1991 & WVS 2014 \\
\hline Mais novos: & & \\
CFI (unidimensional) & .64 & .70 \\
CFI (multidimensional) & .98 & .98 \\
RMSEA (unidimensional) & .14 & .16 \\
RMSEA (multidimensional) & .33 & .34 \\
R eco \& soc / eco \& pp / soc \& pp & $.17 / .06 /-.23$ & $.00 / .03 /-.08$ \\
\hline & WVS 1991 & WVS 2014 \\
\hline Mais velhos: & .60 & .61 \\
CFI (unidimensional) & .98 & .98 \\
CFI (multidimensional) & .12 & .14 \\
RMSEA (unidimensional) & .02 & .47 \\
RMSEA (multidimensional) & $-.09 / .06 /-.20$ & $-.01 / .00 /-.13$ \\
R eco \& soc / eco \& pp / soc \& pp & & \\
\hline Nota: CFI = Comparative Fit Index; & RMSEA $=$ Root Mean \\
Squared Error of Approximation; R $=$ Correlação entre os fa- \\
tores latentes.
\end{tabular}

\subsection{As duas vertentes da ideologia}

Cumpre, então, observar em que medida o posicionamento ideológico dos brasileiros e suas preferências políticas são de fato congruentes. O caminho para esse diagnóstico está no exame do desmembramento entre a ideologia simbólica e a ideologia operacional, de acordo com a seção anteriormente exposta. Em outras palavras, devemos isolar a vinculação afetiva com as categorias esquerda e direta e depois associá-las às inclinações políticas operacionais dos indivíduos, com o propósito de verificar possíveis desarranjos entre ambas.

A parte menos complicada, portanto, é a de construção da medida simbólica, disposta nos bancos de dados do WVS da maneira descrita no capítulo 2:

- Quando se trata de política, as pessoas falam de "esquerda"e de "direita". De um modo geral, onde o (a) sr.(a) colocaria sua visão nesta escala? (WVS, 1991; 2014).

Nesse caso, só importa a autodescrição e não o conteúdo substantivo dos concei- 
tos. Como vimos no capítulo 2 , historicamente, $1 / 5$ dos brasileiros declara não saber o significados dos termos. Somados aos centristas, temos um quadro em torno de $50 \%$ de respondentes que não se posicionam em nenhum dos lados do contínuo. Considerar os ditos moderados faz-se necessário, posto que existem duas interpretações acerca dos pontos médios da escala. A primeira, mais cética, defende insciência dos cidadãos nesse quesito, afirmando que a localização central expressa uma espécie de dissimulação de pessoas sem convicções ideológicas efetivas. A segunda entende os pontos do meio como uma gradação adicional para o mapeamento das opiniões - isto é, esses indivíduos seriam realmente centristas (Kroh, 2007; Hare et al., 2015). De resto, por uma pequena margem, a maioria prefere o dístico da direita ao da esquerda.

Para tratar da ideologia operacional, criamos uma escala aditiva com todas as questões de posição, com a intenção de explorar melhor as preferências políticas. Lembrando, os 11 itens elencados nas edições do WVS 1991 e 2014 remontam a conteúdos econômicos, sociais e próprios ao ornamento da política institucional. Assim, captamos os aspectos cognitivos do que se espera do perfil de esquerdistas e direitistas: o papel do Estado nas matérias econômicas, a liberdade em relação aos comportamentos sociais e a predileção pela ordem.

Opta-se por seguir com o WVS em função do maior número de questões de posição nessas bases e pelo fato das variáveis em pauta possuírem uma redação idêntica, uma vez que pequenas alterações na enunciação de formulários survey podem provocar um viés exógeno na arguição dos entrevistados. Além disso, o exame dos bancos de 1991 e 2014 oferece a oportunidade da verificação de possíveis mudanças ocorridas ao longo do tempo. Vale ressaltar também a exclusão de proposições atinentes à política externa e as que contêm a alusão explícita a nomes de partidos e lideranças políticas expressivas. A seleção de asserções domésticas justifica-se pela diferença dimensional destas para outras envolvendo relações internacionais (Bartle et al., 2011); a retirada das últimas evita um possível viés partidário ou personalista dos respondentes, já que eleitores costumam usar esse tipo de identificação à guisa de atalhos cognitivos (Sniderman et al., 2004).

Em cada issue, por conseguinte, acompanha-se as sugestões de Stimson (2004), classificando os posicionamentos ideais de progressistas e conservadores. Aos primeiros, atribui-se o escore -1 , aos últimos, +1 . Aos pontos médios, o valor zero. Os valores foram 
somados e os cidadãos de esquerda situam-se dentro do somatório compreendido entre os valores negativos, enquanto, os de direita, entre os valores positivos. Assim comparam-se as respostas dadas na escala de autoposicionamento, com a medida ancorada em predileções políticas concretas, a fim de produzir uma variável dicotômica, cuja função é demonstrar a incongruência entre as vertentes simbólica e operacional da ideologia. Em outras palavras: inconsistentes são aqueles que manifestam afinidade com um dos lados da metáfora espacial, mas na prática exibem inclinações opostas. O cruzamento das duas tipologias dá origem, portanto, a quatro categorias distintas: esquerdistas operacional e simbolicamente, direitistas operacional e simbolicamente; simbolicamente esquerdistas e operacionalmente conservadores e simbolicamente direitistas e operacionalmente progressistas. Como o interessante do capítulo reside nos dois últimos casos, a figura 9 revela as porcentagens desses segmentos:

Figura 9: Inconsistência entre as ideologias simbólica e operacional

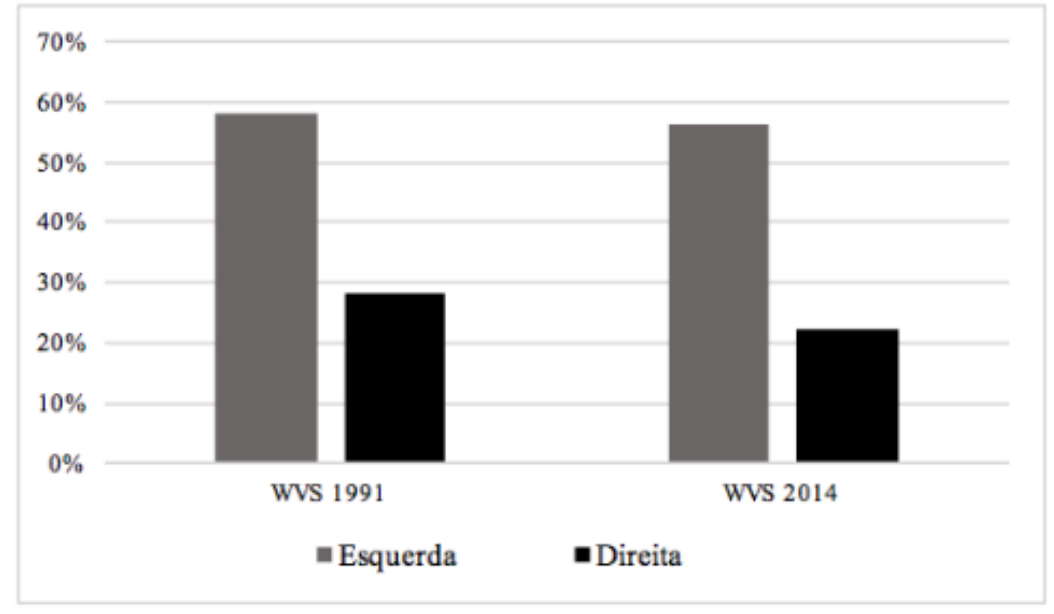

Excluindo os moderados simbólicos e aqueles situados no ponto neutro, temos quatro categorias: duas com os grupos consistentes e outras duas com os grupos conflitantes, ambas à esquerda e à direita. Os casos em evidência, no entanto, são os inconsistentes especialmente os simbolicamente esquerdistas, mas operacionalmente de direita - dispostos na figura. Esses configuram mais do que o dobro dos direitistas conflitantes - tanto em 1991, quanto em 2014. A tendência, ainda, segue padrões relativamente estáveis, com pequenas variações no tamanho dos grupamentos. A inconsistência ideológica dos ditos esquerdistas oscila entre $58 \%$ e 56\%; enquanto do lado conservador ela cai em 8 pontos percentuais (28\% a $22 \%$ ). 
O cenário exposto, por conseguinte, evidencia a propensão exatamente oposta do quadro norte-americano, no qual os "conservadores em conflito"se sobressaem aos liberais inconsistentes. As razões de tais desajustes podem ser de três ordens: o desconhecimento absoluto do significado dos conceitos, a ordenação conflituosa de crenças políticas distintas e/ou algum evento sistemático que contribua para o afastamento simbólico de determinados cidadãos do rótulo da "direita". Embora não tenhamos os instrumentos necessários para provar empiricamente o primeiro tópico, os demais argumentos serão submetidos a escrutínio nas linhas seguintes.

\subsection{A incongruência causada pela multidimensionalidade}

Na seção anterior, comparou-se orientações gerais agregadas, as ideologias simbólica e operacional, conforme a metodologia desenvolvida por Ellis e Stimson (2012). Entretanto, se atentarmos para a tese da multidimensionalidade dos ordenamentos ideológicos, notamos que a agregação de diferentes temáticas em um construto unidimensional mostra-se ineficiente para dar conta do ordenamento das crenças das pessoas.

Tendo em vista a variação das saliências produzidas por dimensionalidades distintas, a escala unidimensional pode camuflar impactos específicos produzidos pelas múltiplas agendas políticas na inconsistência ideológica. O paradoxo simbólico-operacional resultaria, então, em preocupações diferenciadas que os cidadãos conferem às dimensões. Assim, a análise fragmentada dos tópicos econômico, social e relativo à ordem nos permitirá determinar se algum desses âmbitos contribui de maneira desproporcional para a incongruência entre os aspetos afetivo e cognitivo da ideologia. Para saber se os desencontros se estendem aos três campos, e incidem de maneira diferenciada entre esquerdistas e direitistas, deve-se inspecionar a forma com que os mesmos se relacionam com a vertente simbólica da ideologia, como consta na figura 10.

Conquanto as inconsistências se verifiquem em todas as dimensões, as questões atinentes à ordem pública apresentam os menores índices em 1991 e em 2014. Essa particularidade, todavia, já era esperada: como visto no capítulo 2 , o contínuo esquerda-direita ilustra no Brasil a cisão social provocada pelo aprofundamento do cânone democrático, projeto defendido por partidos progressistas, principalmente no momento da abertura po- 
Figura 10: Inconsistência entre as ideologias simbólica e operacional

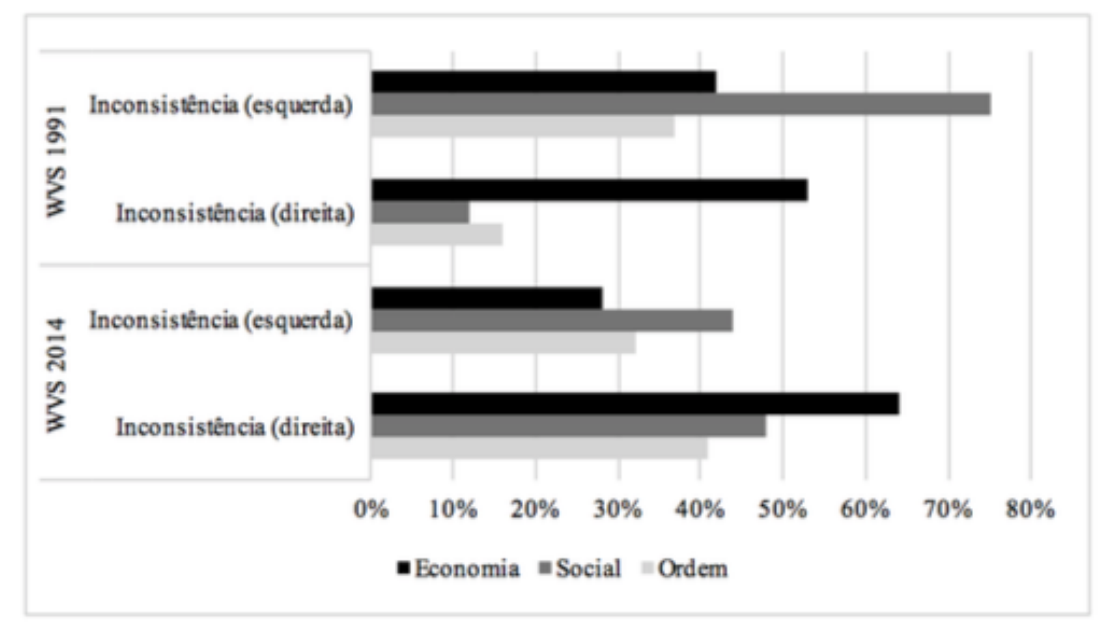

lítica. Os inconsistentes de ambos os lados exibem números similares, que giram entre $16 \%$ e $32 \%$.

Os desacertos na economia afetam a inconsistência dos indivíduos situados à direita, especialmente em 2014 (64\%). Nesse sentido, muitos dos que se consideram conservadores, na verdade, compartilham de visões estatistas acerca do funcionamento de tarefas ligadas à administração pública - tendência análoga à descrita no cenário norteamericano por Ellis e Stimson (2012). Por fim, os aspectos sociais, sobretudo em 1991, pautavam menos a autoidentificação dos respondentes de esquerda, acusando os maiores índices de desacerto $(75 \%)$.

Com a figura 10, portanto, observa-se que as fontes dos desalinhamentos das expressões valorativa e simbólica da ideologia têm naturezas dessemelhantes, apesar de todas as dimensões examinadas conterem elevadas taxas de dissociação. Contudo, além dos aspectos cognitivos, a inconsistência ideológica ainda pode ser motivada por conteúdos sistêmicos associados a desdobramentos particulares da história política nacional. Afinal, quais motivos podem obstar o entendimento dos conceitos esquerda e direita no Brasil?

\subsection{Componentes do desajuste ideológico}

Com efeito, voltemos agora às análises multivariadas de determinantes dos desajustes nas ideologias simbólicas. Os estimadores dos modelos multivariados nos autorizam um exame mais robusto acerca dos efeitos da multidimensionalidade das crenças na incon- 
sistência ideológica, bem como possibilitam a constatação de impactos diferenciados de preditores diversos. A variável dependente será, por conseguinte, a escala de desarranjos entre as ideologias simbólica e operacional, apresentada na seção (3.5). Tendo em vista a natureza binária do construto, opta-se por regressões logísticas probit com mínimos quadrados ponderados e erros-padrão robustos (Gelman e Hill, 2007). Nesse ponto, cumpre ressaltar que os inconsistentes de esquerda e de direita são tratados separadamente. Isso porque, segundo Connover e Feldman (1981), aqueles vinculados ao flanco progressista podem o fazer por razões distintas daqueles que preferem o rumo conservador.

Com efeito, Ellis e Stimson (2012) identificam três caminhos para a aquisição da vertente simbólica, são eles: a constrição ideológica, o resultado do enquadramento do discurso da elite política, a influência de identidades sociais e de valores consolidados. Seguiremos a trilha iluminada pelos autores, mas com algumas considerações atinentes ao caso nacional. Primeiro, acompanhando os trabalhos de Popp e Rudolph (2011) e Claassen et al. (2014), pondera-se de forma mais explícita o peso dos pertencimentos grupais como fonte de possíveis confusões conceituais. Mesmo porque, de acordo com as evidências do capítulo 2, os brasileiros entendem o espectro esquerda-direita especialmente em função de vinculações afetivas, decorrentes da afinidade com grupos sociais específicos. Segundo, partindo da tese da multidimensionalidade, investigaremos a consequência relativa de uma estruturação das crenças em eixos dessemelhantes. Por último, a falta de estudos sobre a elaboração sistematizada das opiniões políticas dos representantes no Brasil e a ausência de uma diferenciação discursiva clara dos grandes meios de comunicação em um país com cenário de oligopólio midiático - ao contrário dos EUA, em que canais populares como NBC e Fox se apresentam em polos opostos no embate das ideias - obstam a parte analítica voltada para as influências top-down, isto é, entre elites e representados.

Dessa forma, pelo âmbito identitário, observamos que os pertencimentos grupais têm o poder de moldar crenças e avaliações individuais, conquanto o reconhecimento pessoal com determinado círculo produz certa correspondência com os estereótipos da coletividade e seus princípios (Connover e Feldman, 1988). Aqui, destacam-se três tipos: a ideologia simbólica, a simpatia partidária e a religiosidade. A força do posicionamento ideológico usualmente encontra-se associada com a incompatibilidade no embate operacional-simbólico (Ellis e Stimson, 2012; Popp e Rudolph, 2011; Claassen, Tucker 
e Smith, et al. 2014). Por isso, a variável foi codificada no formato dummy, com os indivíduos mais afeitos aos extremos da escala recebendo o valor 1 .

A simpatia partidária tem ocupado lugar central na literatura de comportamento político, mediante uma série de processos, incluindo os recursos de priming, atalhos cognitivos e enquadramento (Feldman, 1988; Goren, 2004; Sniderman e Stigliz, 2012). A variável permanece instrumentalizada enquanto apoio ou oposição ao PT. A expectativa, no entanto, é que o antipetismo, especialmente em 2014, seja um símbolo responsável pelo afastamento de cidadãos com valores de esquerda do dístico progressista. Segundo Telles (2016), nas manifestações contrárias à presidenta Dilma Roussef (PT), em 2015 e 2016, depois da corrupção, o tema que mais conecta os manifestantes é a avaliação negativa do partido de Lula ${ }^{37}$.

Até agora constatamos que os religiosos demonstram afeição pelo vocábulo "direita" e afiançam posturas refratárias a condutas sociais não convencionais, segundo exibiram os MEE. Muitos brasileiros trazem para o campo político elementos simbólicos do campo da religião (Oro, 2006) e, por isso, assume-se a possibilidade de influência desse elemento no modelo examinado. Para medir a religiosidade, mantém-se a configuração do regressor como uma variável contínua, elaborada mediante a soma de 4 itens (dispostos no apêndice).

Se os brasileiros pensam o jogo político de maneira multidimensional, a organização das informações em múltiplos eixos assume potencialmente um caráter disruptivo na localização dos respondentes nas escalas unidimensionais. As vertentes operacionais das dimensões econômica, social e da ordem - salientadas nas análises fatoriais - serão adicionadas à equação. Como em todas as seções, as escalas foram construídas para ter os valores conservadores em cada um dos âmbitos com escores mais elevados.

Para Ellis e Stimson (2012), o episódio chave da desorientação ideológica dos norteamericano foi o programa Great Society, posto à prova pelo então presidente Lyndon

\footnotetext{
${ }^{37}$ Conforme Telles (2016), nem só de aspectos simbólicos, pautados no antipetismo, vive o pensamento de direita. Parcelas das camadas médias, imbuídas na retirada da presidenta, compartilhavam de valores anti-igualitários, expressos nas opiniões contrárias às políticas de inclusão social promovidas pelos governos do PT. No capítulo 2, entretanto, ainda que não tenham sido utilizadas as mesmas medidas, a dimensão econômica não marca uma distinção estatística entre esquerdistas e direitistas.
} 
Johnson. Na bibliografia nacional, alguns trabalhos indicam que os legisladores exprimem grande desconforto com o vocábulo "direita", evitando o uso da terminologia. O fenômeno nomeado "direita envergonhada"costuma ser explicado pela suposta vinculação conceitual da categoria com a ditadura civil-militar (Zucco, 2011), a despeito da escassez de comprovações empíricas. A partir de itens relacionados à identificação com as forças armadas (WVS 1991) e apoio aos governos militares (WVS 2014), veremos se o evento se verifica também entre os cidadãos comuns.

Sofisticação política funciona como o elo do modelo entre o discurso dos governantes e os representados. Na literatura especializada, o preditor normalmente afeta o conhecimento e os juízos das pessoas a respeito da política (Converse 1964, Feldman e Steenbergen 2001). Em solo norte-americano, os mais sofisticados costumam emular os posicionamentos de lideranças democratas e republicanas, ao passo que o grosso da população não se define liberal ou conservador. No Brasil, a variável explanatória aparece correntemente ligada ao autoposicionamento simbólico, embora não se possa constatar conteúdos valorativos substanciais nesse pertencimento (Carreirão, 2002; Oliveira e Turgeon, 2014). Não obstante os resultados dos exames fatoriais não revelem distâncias entre as estruturas de crenças dos brasileiros, o regressor será incluído na regressão aos moldes de uma variável controle. Somam-se a ela renda, idade e gênero.

Abaixo, a tabela 15 expõe os efeitos da inconsistência ideológica entre ditos esquerdistas e direitistas em 1991 e 2014. Os achados não apresentam uma uniformidade completa nos dois períodos investigados, mas reforçam alguns argumentos elucidados ao longo do capítulo. Nota-se, portanto, que ter uma forte identificação com qualquer um dos símbolos ligados à ideologia, em qualquer um dos anos, contribui para a incoerência entre os valores reportados e aqueles realmente sustentados pelas pessoas. Em 1991, a socialização geracional importa em relação aos jovens, exprimindo um maior grau de incongruência à esquerda nos grupamentos com idades inferiores. Se, lembrando o capítulo passado, os respondentes mais antigos evitavam com frequência superior a vinculação com a esquerda, produzindo assim menos desacordos. 
Tabela 15: Preditores da inconsistência ideológica

\begin{tabular}{|c|c|c|}
\hline \multicolumn{3}{|c|}{ Painel A: WVS 1991} \\
\hline Variável dependente & Inconsistentes de esquerda & Inconsistentes de direita \\
\hline Id. Ideológica & $2.05(.10)^{*}$ & $1.82(.13)^{*}$ \\
\hline Id. Partidária (PT) & $.21(.12)$ & $-.21(.21)$ \\
\hline Religiosidade & $.01(.10)$ & $.27(.11)^{*}$ \\
\hline Id. Militares & $-.04(.10)$ & $-.15(.13)$ \\
\hline Id. Operacional (Economia) & $-7.69(1.74)^{*}$ & $9.16(2.03)^{*}$ \\
\hline Id. Operacional (Social) & $20.81(1.98)^{*}$ & $-21.77(2.03)^{*}$ \\
\hline Id. Operacional (Ordem) & $-12.51(1.70)^{*}$ & $17.94(2.68)^{*}$ \\
\hline Sofisticação & $2.13(1.67)$ & $-1.42(2.01)$ \\
\hline Renda & $1.06(1.65)$ & $.88(1.97)$ \\
\hline Cor (branco) & $-.14(.11)$ & $.13(.14)$ \\
\hline Idade & $-.96(.24)^{*}$ & $-.08(.27)$ \\
\hline Sexo (homem) & $.08(.09)$ & $.04(.11)$ \\
\hline McFadden & .45 & .60 \\
\hline \multicolumn{3}{|c|}{ Painel B: WVS 2014} \\
\hline Variável dependente & Inconsistentes de Esquerda & Inconsistentes de Direita \\
\hline Id. Ideológica & $1.9(.16)^{*}$ & $3.03(.15)^{*}$ \\
\hline Id. Partidária (PT) & $-26(.15)$ & $.20(.14)$ \\
\hline Religiosidade & $.57(2.09)$ & $.57(1.94)$ \\
\hline Id. Militares & $.20(.13)$ & $.06(.13)$ \\
\hline Id. Operacional (Economia) & $-7.44(3.66)^{*}$ & $9.75(3.73)^{*}$ \\
\hline Id. Operacional (Social) & $19.55(4.02)^{*}$ & $-35.25(4.24)^{*}$ \\
\hline Id. Operacional (Ordem) & $-26.78(4.39)^{*}$ & $28.09(4.64)^{*}$ \\
\hline Sofisticação & $-1.00(2.75)$ & $-.15(2.60)$ \\
\hline Renda & $-1.19(3.05)$ & $-.82(2.94)$ \\
\hline Cor (branco) & $-.09(.13)$ & $.26(.14)$ \\
\hline Idade & $-.08(.40)$ & $-.23(.39)$ \\
\hline Sexo (homem) & $-.10(.14)$ & $.21(.13)$ \\
\hline McFadden & .62 & .61 \\
\hline
\end{tabular}

Nota: Erros-padrão em parênteses; significância estatística a .05

Nota 2: N (WVS 1991) =1782; N (WVS 2014) $=1486$.

Vemos, de outro lado, que a religiosidade pode enviesar os resultados à direita, com os crentes fervorosos afastando-se do dístico progressista. Assim sendo, os religiosos, embora prefiram a adesão simbólica com a direita, em alguns casos não confirmam as 
convicções geralmente relacionadas a esse espectro político.

Cumpre assinalar, ainda, a identificação com as forças armadas (ou a manifestação de apoio a governos militares) não se mostrou um preditor importante para possíveis explicações acerca dos desarranjos ideológicos, conforme especulam outros trabalhos anteriormente citados. A expectativa era que a repulsa aos militares tivesse algum efeito entre os esquerdistas inconsistentes, fato sem comprovação empírica até agora.

De maneira análoga, o antipetismo não confirmou as expectativas entre os direitistas inconsistentes. A sofisticação política, por seu turno, seguiu sem evidenciar diferenças na estruturação do pensamento dos cidadãos e não reduziu a incongruência dos engajados. As demais variáveis controle - gênero, cor e renda - não produziram efeitos relevante no modelo.

Isto posto, são os princípios operacionais os causadores das divergências mais acentuadas em ambas as datas. Todas as dimensões consideradas exibem significância estatística, bem como magnitudes superiores de associação com a variável dependente nos dois lados do espectro político. Os efeitos estatísticos, contudo, são diferentes. Em 1991, os conservadorismos econômico e o relativo à ordem reduzem as chances de inconsistência ideológica, enquanto o social expande essa probabilidade. Em 2014, os operacionalismos econômico, social e político caminham na mesma direção, contendo a possibilidade de desajustes. Os sinais trocados dos coeficientes disseminam, além da ideia da organização distinta das preferências políticas, a noção de que os indivíduos podem combinar de formas heterogêneas as dimensões salientadas. Assim, cabe afirmar que a multidimensionalidade das crenças, ponderando múltiplos elementos, serve de guia principal para a explicação dos determinantes da incompreensão dos conceitos esquerda e direita no Brasil.

\subsection{Postulados normativos e a multidimensionalidade das crenças}

No início dos anos 1970, momento em que as sondagens de opinião pública começavam a se difundir na imprensa francesa, Pierre Bourdieu (1982) sublinhou algumas inconsistências no método que, por colocar a mesma pergunta a pessoas com diferentes origens sociais, postulava alguns predicados de pouca validade empírica, são eles: a noção de que os indivíduos expressam opiniões atinentes a qualquer assunto inquirido, a igualdade 
valorativa dos pontos de vista em uma sociedade cindida por inúmeras desigualdades sociais, e a existência ilusória de acordos mínimos acerca de todos os questionamentos propostos. Segundo o autor, a fabricação prévia enceta uma dupla consequência, a de favorecer a ideia de falsa identificação - já que o mesmo ponto pode ser reconhecido a partir de paradigmas dissonantes - e de engendrar um viés de encerramento, ao delimitar o horizonte de possibilidades do politicamente pensável.

Decerto, várias das críticas realizadas por Bourdieu foram exaustivamente rebatidas ao longo dos últimos decênios (Bishop, 2004). Poucos devem acreditar no fato das pesquisas de opinião só projetarem mistificações ou que os cidadãos não têm opiniões reais sobre matérias de cunho político. Entretanto, os principais entraves das pesquisas survey residem na ambiguidade e no caráter vago da linguagem. O caso estudado neste capítulo, o dos conceitos de esquerda e direita, certamente vai ao encontro dessas preocupações, as quais perpassam não somente o ceticismo bourdiano, mas atravessam também as considerações dos especialistas em técnicas quantitativas.

Ao longo dos anos, a literatura nacional mostrou a localização na escala de autoposicionamento ideológico e o desconhecimento semântico das categorias como fatos condôminos. A justificativa, então, repousava em um arcabouço institucional pouco propício ao desenvolvimento de identificações com ambos os espectros, tese que não resiste a qualquer contrafactual mais exigente - haja vista que a "inocência ideológica" normalmente preenche os diagnósticos preparados por especialistas estrangeiros.

A ambiguidade do contínuo esquerda-direita tem origem, pois, na expansão dos conflitos sociais contemporâneos, cujo lastro foi alargado para comportar os novos issues surgidos no final dos anos 1960. Se o abandono completo dos conceitos não vingou, dada a insuficiência dos mesmos para explicar os hodiernos fenômenos políticos, podemos constatar um arranjo diferenciado das crenças dos cidadãos, assumindo agora uma natureza multidimensional. Dito de forma diferente, os termos esquerda e direita não se restringem a uma leitura economicista, a uma dimensão apenas, mas comportam igualmente preceitos sociais e relativos à forma de condução da política - aspecto que independe da sofisticação política ou da faixa etária dos indivíduos.

A falsa identificação e o encerramento pronunciados por Bourdieu podem ser minimizados com medidas diferentes, cujos enunciados se aproximam do cotidiano do cida- 
dão comum. Contando com o auxílio de uma técnica para lidar com variáveis latentes, mostrou-se a forma heterogênea com que os indivíduos ordenam as dimensões ponderadas e, consequentemente, a multiplicidade das composições ideológicas no Brasil atual.

Aos futuros trabalhos resta a sugestão de acréscimo desses grupamentos alternativos nas análises de comportamento político, a fim de corrigir os desacertos das inferências baseadas na escala de autoposicionamento. Em suma, a fuga de postulados normativos, acerca da maneira como os eleitores deveriam pensar, está em métodos com especificações sobre a variedade de compreensões do universo político. 



\title{
4. Nem tão "Flamengo": o diagnóstico al- ternativo de uma síndrome antecipada
}

\begin{abstract}
Hi.po.con.dria. Sf. "Transtorno psicológico caracterizado por uma preocupação compulsiva e medo constante de sofrer ou vir a sofrer de enfermidade(s) grave(s), a partir de interpretações pessoais baseadas em sintomas somáticos, que persistem a despeito das investigações médicas e que não podem ser atribuídas a uma doença real".
\end{abstract}

- Dicionário Michaelis, edição eletrônica ${ }^{38}$.

Decerto, a enfermidade mais famosa nos diagnósticos da literatura do comportamento eleitoral no Brasil é a "síndrome do Flamengo", cunhada pelo cientista político Fábio Wanderley Reis no final dos anos 1980. Como foi dito no capítulo anterior, o autor relatou dessa forma a suposta simplicidade das percepções e imagens que os eleitores usavam para basear seus entendimentos e condutas acerca da política institucional. Nesse sentido, o fato de os cidadãos não possuírem crenças estruturadas atinentes ao jogo democrático afetou, por consequência, a decisão eleitoral dos indivíduos - ancoradas no populismo e em vinculações personalistas. Reis (1988), vale observar, quando indicou o sintoma, referia-se a outro momento da política nacional, o início do período da abertura democrática ${ }^{39}$.

O efeito de contágio dessa prescrição provocou, então, uma epidemia na literatura especializada, que depositou pouca atenção aos condicionantes empíricos da tese. Assim, as análises dos determinantes do voto padecem de verificações acuradas sobre a pertinência do exame desenvolvido, aparentando uma espécie de transtorno hipocondríaco - no qual os prognósticos foram sentidos sem uma manifestação concreta da psicopatologia.

O objetivo das páginas seguintes é o de preencher essa lacuna, testando a precisão do arrazoado. Os estágios serão compostos de duas partes: na primeira, verifica-se a validade dessa interpretação mediante o exame de uma possível associação entre questões

\footnotetext{
${ }^{38}$ Retirado do endereço eletrônico http://michaelis.uol.com.br/busca?r=0\&f=0\&t=0\&palavra= hipocondria, acesso em 16 de dezembro de 2016, às 15:02 min.

${ }^{39}$ Para Reis, esse paradigma explicativo servia para elucidar tanto o "crescente êxito eleitoral de um PTB [Partido dos Trabalhadores do Brasil] ou a afirmação eleitoral de um MDB [Movimento Democrático Brasileiro] a partir de 1974, bem como os prospectos favoráveis que se abrem para o PT"(Reis, 1988:23).
} 
de posição (issues) e o voto. Na segunda, uma vistoria mais abrangente, de grupamentos ideológicos heterogêneos, seus perfis sociodemográficos e relações com o comportamento eleitoral.

Em ambas, um parecer constituído pelos desdobramentos iniciais deste trabalho: a contribuição de técnicas latentes à pesquisa social e, consequentemente, os resultados distintos provocados pela utilização de uma vertente operacional da ideologia. Além das Análises Fatoriais, a confirmação de uma interpretação alternativa está fundamentada na Análise de Classes Latentes (ACL) - recurso adequado a uma classificação prévia da distribuição dos grupos ideológicos presentes no Brasil contemporâneo.

Como resultado, constata-se a presença infundada dos postulados que atribuem aos votantes de "jovens democracias"uma orientação pouco complexa, respaldada pela identificação com os traços pessoais dos representantes, o clientelismo e o julgamento do desempenho dos governantes. Salvo no pleito de 2002, a relevância das concepções simbólicas, e não meramente materiais, das condutas dos cidadãos mostraram-se estatisticamente significativas em todos os anos explorados.

\subsection{Perspectivas acerca dos condicionantes do voto no Brasil}

Conforme Delli-Carpini e Keeter (1996), o pensamento político clássico sempre se preocupou em vincular a democracia à capacidade intelectual e moral de homens e mulheres de se autogovernarem. Todavia, a composição institucional dos dias de hoje, marcada por um regimento liberal, traz à tona incentivos paradoxais, na medida em que autoriza o envolvimento e, ao mesmo tempo, fornece mensagens contraditórias acerca da importância da cooperação em causas coletivas, sinalizando com oportunidades desiguais de engajamento para diferentes grupos (Rancière, 2015). Como pode, portanto, ser factível que indivíduos geralmente mal informados, pouco participativos e submetidos a condições materiais e simbólicas diferentes tomem parte das agendas públicas de maneira efetiva?

O estatuto quase consensual das pesquisas sobre as opiniões dos votantes aponta em direção à ignorância espraiada em relação a temas políticos. Os desdobramentos dessa constatação conduzem a dois caminhos distintos. O primeiro, trilhado pelos mais pessimistas, assinala o comportamento eleitoral como uma representação sem sentido, 
haja vista a desatenção dos sufragistas acerca dos enunciados coletivos. O segundo, na verdade, segue uma bifurcação: existem os que defendem o caráter corretivo dos meios de agregação de preferências (Shapiro, 2011), e aqueles cujo argumento enfatiza o fato de os eleitores não precisarem de informações completas para tomar boas decisões (Lupia, 1994).

Ficando somente com as vertentes otimistas, a literatura internacional, desde 1980, tem procurado captar o compasso das transformações na opinião pública, voltando sua atenção para os eleitores em nível agregado - os cidadãos como um todo, em vez de votantes individuais -, levando em conta seu posicionamento mediano. O objetivo, na maioria dos casos, consiste em entender como e por que a opinião pública se move e, sobretudo, verificar possíveis relações de causa e efeito entre essas oscilações e a responsividade dos governantes em atender as demandas da população (Page e Shapiro, 1984; Erikson, Mackuen e Stimson; Stimson, 2004; Ellis e Stimson, 2012; Shapiro, 2011) ${ }^{40}$. Por conseguinte, conquanto a resenha sobre a formação das preferências se inscreva numa lógica de intercâmbio entre representantes e representados, cabe ressaltar que as opiniões a respeito do jogo político não são fatores inertes, mas se movimentam com o passar dos anos.

Essa concepção difere decisivamente da forma como a maioria dos especialistas interpreta as respostas do eleitorado. Nela destacam-se dois pontos principais: ao contrário de uma leitura estática, privilegia-se o dinamismo; no lugar de postulados pouco elogiosos acerca da capacidade de entendimento das pessoas comuns sobre o mundo político, uma postura mais atenta ao que a literatura americana costuma chamar de issues, e a possibilidade destes afetarem a vida pública (Kinder, 2006) ${ }^{41}$.

\footnotetext{
${ }^{40}$ Stimson (2004), por exemplo, analisam amplas séries históricas de opiniões conectadas às questões políticas, e as consequentes mudanças ocorridas no tempo. É de formulação dos autores, inclusive, o conceito de "representação dinâmica"- análise desenvolvida de maneira intensa em período recente.

${ }^{41}$ Tal visão sobre o pouco conhecimento dos eleitores ordinários tem no trabalho clássico de Converse (1964) o seu principal bastião. Para o autor, a inconsistência da população no momento de responder perguntas simples demonstra a falta de capacidade dos cidadãos de emitirem opiniões a respeito de conteúdos do universo político. Somada à falta de estruturação, o balanço apontava também um desinteresse geral de aspectos da vida pública, o que levou Converse à conclusão da "inocência ideológica" dos indivíduos em geral. A observação do ritmo de ondas agregadas de opinião pública e os consequentes rumos da política em diversos países ajudam a pelo menos matizar a convicção de que os resultados dos questionários aplicados guardam um sentido nem tão rudimentar, chegando mesmo a prescrever os receituários
} 
Não obstante as pesquisas de opinião tenham se popularizado cada vez mais no decorrer do tempo, dois aspectos principais dificultaram a capacidade dos cientistas políticos brasileiros em medir as variações das preferências em um arranjo longitudinal: 1) a escassez de dados concernentes a questões de posição, o que atrapalha o uso de técnicas de redução mais simples, como a análise fatorial; 2) as poucas perguntas apresentadas nos questionários não exibem formulações similares em períodos subsequentes, tornando a análise ainda mais complicada. Essa dispersão dos dados survey forçou os especialistas a restringirem o escopo de investigação a um pequeno número de estudos acadêmicos com muitas variáveis ou a alguns tópicos ao longo de um curto período.

Por seu turno, uma série de autores ressalta o fato da falta de necessidade de informações plenas para sorver decisões baseadas em escolhas racionais. Bastariam atalhos cognitivos, ou seja, o encadeamento de heurísticas que sintetizam e reduzem os custos de obtenção para ensejar resoluções razoáveis do grande público (Huckfeldt e Sprague, 1995; Lupia e McCubbins, 2000; Klingeman, 2009). O voto e os demais comportamentos propriamente políticos seriam, assim, escolhas assemelhadas a orientações conduzidas por meio de condições informacionais completas. Ademais, o uso dos atalhos cognitivos não evidencia o sintoma de baixa sofisticação intelectual, mas uma forma racional de lidar com as referências disponíveis (Rennó, 2001).

Para Sniderman, Tetlock e Elms (2001), no entanto, o funcionamento dos atalhos cognitivos opera de acordo com um condicionante: a complexidade dos sistemas políticos. Nos EUA, o êxito desse recurso se dá em função da simplicidade do arranjo institucional, já que facilita a compreensão do jogo político em um ambiente bipartidário, como algo marcado pela lógica "nós contra eles". No caso brasileiro, Rennó (2001) destaca que a complexidade de um quadro institucional multipartidário dificulta o emprego dessas heurísticas. Afinal, a dependência estatal dos partidos, as coligações e coalizões heterogêneas (superando as clivagens binárias governo x oposição, direita x esquerda), a diminuição das distâncias ideológicas e a atenuação da diferença entre ganhadores e perdedores em termos de acesso a recursos estatais, sugerem a possibilidade de cartelização da política brasileira e, por conseguinte, o embaraço na atribuição de diferenças aos postulantes em disputa (Ribeiro, 2013).

adotados pelos governantes em períodos subsequentes (KINDER, 2006). 
A personalização da escolha dos dirigentes, embora um episódio de escopo global ${ }^{42}$, encontra no sistema representativo proporcional de lista aberta, adotado no Brasil, outro considerável impulso (Tavares, 1994; Samuels, 1997; Ames, 2003; Nicolau, 2006). Neste tipo de regulação, compete aos eleitores a escolha das possíveis lideranças que irão ocupar as cadeiras conquistadas pelas legendas ou coligações. Esse sistema normatiza as eleições da maior parte dos pleitos - incluindo a Câmara dos Deputados, Assembleias Legislativas e Câmaras dos Vereadores - oferecendo duas opções ao eleitorado: a alternativa por nomes ou partidos. A disposição dos candidatos é fixada numa lista não ordenada pelas agremiações, para que o votante possa indicar suas preferências. Assim sendo, a composição dos postos procede do somatório dos sufrágios obtidos e da verificação dos concorrentes mais votados. Entre as principais consequências deste ordenamento, incluem-se a fragilização da identificação dos cidadãos com as legendas, a dificuldade de controle das candidaturas e o incitamento da competição intrapartidária (Nicolau, 2006).

Com efeito, a estruturação das crenças políticas não constam nos exames de parte dos analistas, diante de um cenário institucional complexo combinado a uma realidade social incompatível, em que a maioria dos eleitores carece de níveis de conhecimento e de condições materiais apropriadas para exercer a cidadania. Assim, a "síndrome do Flamengo", criada por Reis (1988), e as teses sobre o comportamento político dos brasileiros inspiradas nessa versão - citadas no capítulo anterior - vingaram de fato na literatura nacional.

A concepção de um sufragista cujas ideias políticas figuram em bases fragmentárias e logicamente sem nexo, da atuação política alicerçada em dinâmicas morais, personalistas e em conluio com compromissos clientelistas, da baixa identificação partidária e ideológica, de um voto com caráter moral e assentado em noções intuitivas e emocionais, então pulularam nos trabalhos dos politólogos, especialmente no período de redemocratização. Silveira (1996) chegou a conceber um novo tipo ideal: o do "eleitor não-racional", aquele que conjuga todas as características acima expostas ${ }^{43}$. De todo modo, em razão da baixa

\footnotetext{
${ }^{42}$ Para Manin (1997), os sistemas representativos globais sofreram alterações profundas em virtude da consolidação dos meios de comunicação de massa. Segundo o autor, a comunicação direta - sem a necessidade de intermediação dos partidos políticos - possibilitada pelos avanços tecnológicos contribuiu para fomentar uma relação mais personalista entre representantes e representados.

${ }^{43}$ Vale explicitar, entretanto, que o autor não reivindica a unicidade dessa espécie de personagem no
} 
identificação e saber político, a compreensão dos conteúdos coletivos no arquétipo sublinhado se daria de forma desordenada e, assim, concorreria para o aumento da volatilidade das preferências desses indivíduos ${ }^{44}$. Para Carreirão (2002):

O pressuposto de que os leitores conhecem as posições dos candidatos em issues salientes, de que eles conhecem suas próprias preferências perante esses issues e de que eles conceptualizam os resultados eleitorais em termos de dimensões políticas bem definidas, parece estar em desacordo fundamental com as descobertas de décadas de pesquisas de opinião (Carreirão, 2002:48).

O "desacordo fundamental", evidenciado pelo autor, encontra suporte ainda em trabalhos com desenhos comparados. A título de exemplo, Kitscheldt (2000) considera os sistemas político-partidários latino-americanos menos programaticamente organizados se comparados aos correlatos da Europa Ocidental. Na escala dos autores, nenhum dos doze países ponderados exibe altos níveis nesse quesito, somente Chile e Uruguai atingem pontos intermediários. Nesse sentido, os compósitos institucionais com alta polarização, menores esforços clientelísticos e menos partidariamente fragmentados teriam mais chances de produzir eleitores orientados por questões de posição.

Por fim, a carência de um conhecimento objetivo acerca dos vocábulos esquerda e direita e a falta de estruturação ideológica das crenças - aspectos analisados nos capítulos 2 e 3, respectivamente - colaboram para o sepultamento de investigações relativas aos issue oriented voters. Os estudos atinentes ao comportamento eleitoral dos brasileiros desenvolveram-se, portanto, sob o pano de fundo de certa incapacidade cognitiva dos eleitores em ajustar suas predileções aos programas políticos oferecidos pelos candidatos. Em outras palavras, de modo geral, a "síndrome do Flamengo teve um efeito de contágio país. Silveira (1996) formulou uma tipologia com 23 quadros distintos de tomadas de decisão, agrupadas em três grupos distintos: o "comportamento não-racional tradicional", o "novo comportamento nãoracional"e o "comportamento racional"(Silveira, 1996: 264).

\footnotetext{
${ }^{44}$ Sobre a volatilidade, Peres, Ricci e Rennó (2011) mostram que o fenômeno no país não se encontra num grau tão elevado como indicado pela literatura especializada. Entre os principais achados do trabalho, estão os supostos de que a evolução da volatilidade tem sido decrescente com o passar dos anos, que os índices variam conforme os distritos e as variáveis políticas - e não as sociais ou econômicas - são os principais componentes associados a esse evento.
} 
nos especialistas nacionais, que deixaram em quarentena a possível congruência entre as preferências temáticas e a direção do voto.

Signatário dessa teoria, o livro O voto para presidente no Brasil: condicionantes e fatores explicativos (Bonifácio et al., 2014) fornece um preciso catálogo dos principais elementos discutidos pela literatura nos últimos anos - sistema eleitoral, financiamento de campanha, sofisticação política, voto econômico, influência dos grupos religiosos, corrupção, papel da mídia, interferência das emoções, além de um inconclusivo artigo a respeito da ascendência da ideologia -, ratificando o pouco entusiasmo dos politólogos com o nexo dos posicionamentos políticos e a conduta observada nas urnas.

Dos elementos considerados, certamente o fator econômico ocupa lugar central nas inferências, já que a ponderação das diretrizes da economia seria mais simples e direta e se acomodaria melhor a um cenário de eleitores supostamente menos sofisticados (Mendes e Venturi, 1994; Carreirão, 1999, 2007; Nicolau, 2007; Soares e Terron, 2008; Licio, Rennó e Castro, 2009; Peixoto e Rennó, 2011). O raciocínio por trás dessa lógica é claro: as pessoas votam para punir ou recompensar os governos, em diferentes matizes - nas concepções egotrópica ou sociotrópica, no arranjo temporal retrospectivo, momentâneo ou prospectivo e no cruzamento dessas dinâmicas ${ }^{45}$. Por óbvio, se a economia vai bem, o incumbente recebe maior apoio; se vai mal, a oposição se beneficia (Key, 1966). Assim, conforme Figueiredo (2008), parodiando as correntes científicas usadas para a compreensão do comportamento eleitoral, o homo psicologicus e o homo sociologicus cederam bastante espaço ao homo economicus na literatura nacional.

Modelos recentes têm focado ainda em políticas distributivas - sobretudo o Programa Bolsa Família $(\mathrm{PBF})^{46}$ - para compreender o modo como estas impactam a competição eleitoral (Hunter e Power, 2007; Nicolau e Peixoto, 2007; Zucco, 2013; Soares e Terron, 2008; Licio, Rennó e Castro, 2009; Amaral e Ribeiro, 2015). O tom, mais ou

\footnotetext{
${ }^{45}$ Para uma discussão pormenorizada dos tipos de voto econômico, ver Lewis-Beck (1985).

${ }^{46} \mathrm{O}$ Bolsa-Família é o principal programa de transferência de renda do governo federal. A iniciativa unificou os outros programas de distribuição de renda condicionados, como o Bolsa-Escola e o BolsaAlimentação. Atualmente, o PBF atende cerca de 14 milhões de famílias, segundo os dados do Ministério do Desenvolvimento Social. https://mds.gov.br/assuntos/bolsa-familia/dados. Acesso em: 6 dez. 2016, 21h40min.
} 
menos consensual, revela a ressonância efetiva na lógica da disputa entre PT e PSDB, vocalizando a inversão das bases das duas legendas nos interstícios do pleito presidencial de 2006, em grande parte devido ao efeito do PBF (Singer, 1999) ${ }^{47}$.

Os efeitos dessas iniciativas afinadas com a redução da pobreza, orquestradas sob a égide dos governos Lula (2003-2010), produziram resultados na autopercepção da situação de classe dos segmentos mais carentes da população. Como corolário, a ascensão social passou a fulgurar enquanto preditor das disposições políticas, sob a batuta de Peixoto e Rennó (2011). Em vez do voto econômico sociotrópico, a recompensa aos condutores responsáveis pelas melhorias individuais - o apoio eleitoral por parte dos representados colaborou com o sucesso da candidatura da outsider Dilma (PT), em 2010.

Ainda na seara das questões de valência - os temas consensuais, cujo mote se revolve de concordância por ambos os contendores do jogo político- e da análise do desempenho dos representantes, Rennó (2010) e Rennó e Ames (2014) ressaltam o peso da corrupção como um prisma de sanção aos representantes. Para os autores, o envolvimento em escândalos de corrupção prejudicou as intenções de Lula (PT), em 2006, e Dilma (PT), em 2010. Nos trabalhos citados, a imputação de responsabilidade dos eleitores aos mandatários seria mais efetiva em virtude de um ambiente onde os principais determinantes de longo prazo - as identificações partidária e ideológica - estão ausentes ${ }^{48}$.

A importância dos partidos, aliás, figura no rol dos preditores usualmente examinados, embora conte com as devidas discordâncias. De um lado, os que enfatizam o protagonismo monológico do PT (Carreirão e Barbetta, 2004), espécie de condutor fundamental da simpatia e da rejeição nas escolhas eleitorais; de outro estudos mais otimistas, destacam a estabilização dialógica da disputa PT e PSDB, desde as eleições de 1994, para ressaltar a força da variável nos resultados das urnas (Limongi e Cortez, 2010; Braga e Pimentel, 2011; Samuels e Zucco, 2014). Nesse sentido, no entanto, os contornos da

\footnotetext{
${ }^{47}$ Outro programa relevante, usualmente analisado nos estudos de comportamento eleitoral, é o Benefício de Prestação Continuada (BPC), uma política de transferência de renda para idosos e pessoas não aptas ao trabalho. Sobre o assunto, ver Soares et al. (2006).

${ }^{48}$ Outro trabalho de comportamento político tem a corrupção em seu cerne: o estudo de Bonifácio (2013) sobre a aceitação dos cidadãos com a ideia do "rouba, mas faz". A concordância com a conduta de políticos que incorrem em atos de corrupção, segundo o autor, está positivamente com eleitores mais jovens e menos escolarizados.
} 
simpatia com as legendas não precisam necessariamente se revestir de tons programáticos: Samuels (2004) expõe a tese de que o petismo representa, em alguma medida, a expressão do lulismo - ou seja, uma vinculação afetiva de natureza personalística com as características de Lula, retomando assim os padrões tradicionais da política brasileira.

O personalismo é a variável mais importante para explicar as eleições no país, segundo alguns autores (Mettenheim, 1995; Carreirão, 2002; Almeida, 2004). Os atributos pessoais, conquanto tenham o peso balanceado por circunstâncias peculiares a cada pleito, exibem constância nas pesquisas de comportamento político, sobretudo as características supostamente atinentes ao bom exercício do mandato: honestidade, sinceridade e experiência político-administrativa (Carreirão, 2002: 210).

O clientelismo, outra faceta da política latino-americana, mais uma concertação produzida pelo sistema político-eleitoral, induz as lideranças locais ou regionais a fazerem uso de recursos públicos a fim de construir e sustentar suas bases de apoio (Samules, 1997). Não bastasse o sistema de lista aberta e sua contribuição decisiva para o personalismo da política, o número excessivo de partidos, as regras procedimentais que dificultam as tomadas de decisão parlamentares (Deus e Freitas, 2014), as políticas do tipo pork barrel ${ }^{49}$ têm um componente adicional: a expectativa dos representados em relação à atuação legislativa dos representantes (Ames et al., 2014). Com efeito, lançar mão de benefícios particulares com custo difuso faz parte da estratégia dos parlamentares de se manter em seus cargos, tendo em conta que estes têm ciência da predileção de seu eleitorado com vistas ao exercício particularístico do mandato. Nessa leitura, o clientelismo pode ser entendido pelo ângulo da confluência e da responsividade entre governantes e governados.

Na linhagem sociológica das explicações do sufrágio, a religião - especialmente a evangélica - vem se tornando o carro-chefe das análises em períodos recentes (Oro, 2003; Bohn, 2004; Rodrigues e Fuks, 2015). O bloco protestante, com atuação modesta até os anos 1980, chama a atenção desde os debates da Assembleia Constituinte de 1986. Os sucessivos êxitos eleitorais de candidatos ligados a esses segmentos religiosos, sobretudo nos pleitos legislativos, despertam progressivamente a curiosidade dos estudiosos ${ }^{50}$.

\footnotetext{
${ }^{49}$ Em inglês, pork barrel denota o emprego de benefícoos particularistas, e com custo difuso, pelos representantes. Em bom português, é o correlato do clientelismo.

${ }^{50}$ Se a destreza programática dos cidadãos brasileiros não vingou na literatura especializada, o mesmo
} 


\subsubsection{Os diagnósticos alternativos}

Se a vasta maioria dos estudos corrobora a tese de que o comportamento dos eleitores em novas democracias se reduz à avaliação do desempenho de governos incumbentes ou à apreciação de apelos clientelísticos, realizados por lideranças carismáticas, os poucos trabalhos produzidos com a tentativa de encontrar vínculos sólidos entre as diretrizes econômicas e sociais dos representantes e as preferências dos representados se depararam com achados um tanto excêntricos: existe, de fato, congruência de expectativas e performances peculiares às duas partes.

Surpreende nessas investigações a evidência de um tipo de cidadão que orienta suas condutas políticas em virtude de posicionamentos reais acerca de temas específicos. De outro modo, detectou-se a presença de uma espécie rara em ambiente pouco propício à sua reprodução: o eleitor guiado por questões de posição, em um país marcado por indicadores sociais desfavoráveis e um sistema político-eleitoral pautado pelo multipartidarismo. Antes de avançar, no entanto, cabe uma breve revisão do que isso significa exatamente.

O voto orientado por questões de posição ocorre quando o votante, dentre as opções disponíveis, opta pelo candidato que melhor representa suas visões de mundo (Stokes, 1963). Decerto, as matérias sob julgamento devem fazer sentido e ter a saliência atestada por ambos os lados do jogo político. As questões de posição, ao contrário das de valência, causam segmentações entre os atores sociais - casos do casamento de pessoas do mesmo sexo, o papel do Estado na economia, a aceitação do aborto, etc. Se pensarmos em pontos ideais, quanto ao segundo conceito, a sociedade estaria localizada em um mesmo lugar; enquanto no primeiro, ela se dividiria em lados distintos, para ficar na metáfora espacial. Por conseguinte, tal atuação também se diferencia de condutas clientelísticas - a troca do sufrágio por benefícios privados exclusivos - ou personalistas - cujos traços pessoais norteiam a interface.

Assim sendo, voltando à exposição bibliográfica, algumas poucas análises examinaram direta ou indiretamente o impacto dos issues nos resultados eleitorais. Conquanto

pode ser dito da potência das emoções na escolha do voto. Os poucos trabalhos empíricos existentes, no entanto, enfatizam o vínculo das emoções e da razão no processo cognitivo, argumento em consonância com o primeiro capítulo da presente tese (Lavareda, 2009; Pimentel, 2010). 
não fosse o cerne de suas intenções, Rennó e Ames (2011) testaram a importância da aprovação do aborto na direção do voto em 2010 e concluíram que a pauta trouxe prejuízos para Dilma Roussef (PT), especialmente no segmento evangélico, servindo para "acentuar as clivagens religiosas e mostrar a força que temas ligados à religião podem ter em eleições"(Rennó e Ames, 2011: 212). Por seu turno, Baker e Greene (2011), explorando a "guinada à esquerda"na América Latina, apontaram como causa central do sucesso das legendas progressistas no continente o declínio do entusiasmo dos latino-americanos com as reformas de mercado. A combinação de atitudes ambíguas em relação à condução da economia entre os votantes do continente, com suporte ao livre comércio e oposição às privatizações, autorizavam, enfim, partidos de oposição ao modelo hegemônico a modificar de maneira ponderada o projeto edificado durante os tempos do chamado Consenso Washington.

Nesse sentido, Bello (2016) foi mais a fundo e investigou o correct voting (voto correto), criado por Lau e Redlawsk (2006), no Brasil. O autor - considerando proposições atinentes à reforma agrária, gastos sociais, ideologia e privatização - concluiu que o ato de escolher os representantes que melhor defenderam as predileções da população ocorreu em níveis significativos no país - $67 \%$ no primeiro turno e $80 \%$ no segundo turno - nos pleitos de 2002. Em sua versão, os brasileiros aprenderam a "votar corretamente" graças a um fator informal, o contexto social imediato, mediante as conversas interpessoais.

As pesquisas elencadas até aqui se estruturam com base em itens individuais. Uma virada metodológica, todavia, permite uma averiguação mais robusta do fenômeno. Trata-se, como foi dito nos capítulos anteriores, da construção de índices compósitos para inferir sobre as preferências políticas, fato sugerido por Achen (1975) e posto à prova por Ansolabehere et al. (2008). Nesses índices, criados a partir da variação compartilhada de diversas preditores, capta-se a dimensão latente das opiniões a respeito de uma pauta específica.

Com efeito, novamente Bakker e Greene (2015), utilizando a técnica descrita, testaram a influência de issues fatorializados na direção de voto nos países antes observados. E o desfecho foi semelhante: em pelo menos quatorze nações do continente, ao longo dos últimos quinze anos, tivemos o positional issue voting em níveis estatisticamente significativos nos enunciados ligados à economia - sobretudo no Brasil e no México, únicos 
exemplares com dados de painel disponíveis.

Contudo, em todas as análises catalogadas temos de lidar com duas limitações: o exame de apenas alguns poucos itens e a inspeção restrita a um modesto número de eleições. No primeiro ponto, oculta-se a possibilidade de identificar outros temas de relevo para o comportamento eleitoral; no segundo, encobre-se o fator contextual dos pleitos, negligenciando a perspectiva de cenários eleitorais diferentes, com maior politização e/ou polarização ideológica - que, acredita-se, podem enviesar os resultados em virtude de fomentar engajamento e ascendência exagerada sobre os eleitores em um momento específico.

Em relação aos trabalhos de Bakker e Greene (2015) e Bello (2016), a estratégia adotada tem duas desvantagens. Por não tratar os dados conforme estruturas dinâmicas - caso do artigo dos autores estadunidenses - assume-se o risco de endogeneidade. A presente seção não se preocupa também com as causas do desenvolvimento de compreensões estruturadas do universo político entre os eleitores - efeito investigado por Bello.

No capítulo anterior, portanto, verificou-se que os brasileiros têm posições consistentes a respeito das questões políticas. Porém, torna-se necessário investigar em que medida essas inclinações influenciam no voto.

\subsection{Os issues e o voto}

Para testar a hipótese de que os eleitores fazem uso das questões de posição a fim de de guiar seu comportamento nas urnas, utilizam-se diversas bases com o objetivo de mapear os pleitos presidenciais ao longo dos anos. Como critérios para a escolha do material empírico privilegiou-se dois aspectos: 1) a opção por bancos de dados com o maior número de questões de posição e de variáveis consideradas importantes pela literatura especializada, com o fito de examinar a influência desses fatores na escolha do(a) presidente(a) 2) a seleção de bases pós-eleitorais, já que os eleitores no país são mais voláteis, ou seja, tendem a mudar de voto com maior facilidade ${ }^{51}$.

\footnotetext{
${ }^{51}$ Nesse ponto, agradeço o eficiente trabalho de cessão dos dados realizado pelo Centro de Estudos de Opinião Pública (CESOP). Vale dizer, a concentração de pesquisas de opinião pública em um único órgão facilita sobremaneira os esforços dos analistas especializados.
} 
De antemão, cabe ressaltar que nem sempre os parâmetros foram cumpridos, em virtude da indisponibilidade de dados adequados para a presente investigação. O registro mais grave é a ausência de bons indicadores nos pleitos de 1994 e 1998, no período das disputas entre Fernando Henrique Cardoso (PSDB) e Lula (PT). Logo, o exame dos condicionantes não consta nas tabelas subsequentes.

O uso do Datafolha/Cultura Política de 1993 para fazer inferências sobre o pleito de 1989 pode ser considerado outro "desvio". Isso porque, conforme o primeiro critério levantado, o estudo figura como o mais apropriado para captar os desígnios ideológicos dos cidadãos, quando cotejado a pesquisas alternativas - sobretudo do Datafolha/Cultura Política de 1989. O maior revés dessa escolha está na distância temporal da coleta de dados, que torna a declaração do voto mais imprecisa. No entanto, a consulta do resultado do embate entre Collor (PRN) e o candidato petista no Tribunal Superior Eleitoral não expõe grandes diferenças das intenções de voto na base designada ${ }^{52}$.

De resto, as pesquisas apreciadas foram o Estudo Eleitoral Brasileiro (ESEB) de 2002 e 2014; e o Barômetro das Américas (LAPOP), versões 2006 e 2010. Assim, contemplamos $70 \%$ do total de eleições da República fundada em 1988. Cabe informar ainda que os itens não se repetem nos anos subsequentes ou não têm a mesma configuração, o que dificulta um pouco as medidas de comparabilidade.

As variáveis dependentes nos modelos abaixo possuem uma configuração binária, simulando a decisão do segundo turno dos pleitos presidenciais. Na configuração dummy, excluímos os casos faltantes, as abstenções, e assinalamos os candidatos petistas como categorias omitidas. As questões de posição foram novamente fatorializadas e as dimensões econômica, social e da predileção pela ordem perpassam todas as regressões probit - exceto no ano de 2014, em que o questionário estruturado permite o agrupamento somente da primeira dimensão sublinhada. Sem exceção, os itens rodaram na direção esperada e tiveram coeficientes significativos em todos os anos. Acompanhando os capítulos 2 e 3, os coeficientes possuem uma escala com variância de 1, e os valores mais elevados indicam

\footnotetext{
${ }^{52}$ Segundo consulta ao sítio do Tribunal Superior de Justiça (TSE), Collor conquistou 53\% dos votos, enquanto Lula galvanizou 46\% do apoio. Enquanto isso, na base do Datafolha/Cultura Política de 1993, Collor aparece com $56 \%$ das probabilidades de voto e Lula com $43 \%$.
} 
orientações conservadoras nas respectivas dimensões ${ }^{53}$.

Fazem parte também das equações variáveis relativas aos determinantes contemplados nas seções anteriores: avaliações do desempenho econômico e do governo, identificação partidária, percepções acerca da economia, consciência subjetiva de ascensão social, opinião acerca das características pessoais dos candidatos, denominação religiosa, sofisticação e demais controles socioeconômicos.

Na tabela 16 estão dispostos os resultados dos coeficientes padronizados e os errospadrão (em parênteses) dos modelos por ano. Salvo em 2002, pelo menos uma dimensão se mostrou estatisticamente significante em todas as regressões estimadas, contrariando de imediato a tese da "síndrome do Flamengo".

Se olharmos os períodos separadamente, em 1993, época da hegemonia dos ditames pró-mercado, a economia não teve peso na escolha eleitoral, ao passo que o conservadorismo atinente aos costumes sociais e à participação popular estão positivamente associados com o sufrágio em Collor (PRN).

Em contraste, as avaliações de desempenho, um dos aspectos preponderantes das conceituações de comportamento político, não evidenciam o protagonismo revelado em momentos posteriores. Também pudera: as candidaturas mais fortes daquele pleito se apresentavam em situação de ruptura com as lideranças incumbentes. Por consequência, nem o postulante do PRN tampouco Lula seriam capazes de galvanizar o apoio ao governo Sarney, fato que transforma a disputa em um embate sui generis no contexto dos embates presidenciais no país. Além dos issues, a simpatia pelo dirigente petista, a sofisticação política, a escolaridade e as identificações partidárias atestaram importância como preditores do voto no primeiro escrutínio popular para o chefe do executivo federal após a ditadura civil-militar.

\footnotetext{
${ }^{53}$ Os resultados das análises fatoriais estão no apêndice metodológico.
} 
Tabela 16: Determinantes do voto no Brasil

\begin{tabular}{|c|c|c|c|c|c|}
\hline & CP 1993 & ESEB 2002 & LAPOP 2006 & LAPOP 2010 & ESEB 2014 \\
\hline \multicolumn{6}{|l|}{ Questões de posição } \\
\hline Dimensão econômica & $0,10(0,17)$ & $0,00(0,01)$ & $0,55(0,17)^{*}$ & $0,17(0,07)^{*}$ & $0,28(0,10)^{*}$ \\
\hline Dimensão social & $0,23(0,08)^{*}$ & $0,03(0,02)$ & $0,14(0,08)$ & $0,07(0,06)$ & \\
\hline Ordem & $0,24(0,07)^{*}$ & $0,00(0,01)$ & $-0,14(0,11)$ & $0,03(0,05)$ & \\
\hline \multicolumn{6}{|l|}{ Avaliação desempenho } \\
\hline Av. retrospectiva (geral) & $-0,04(0,04)$ & & $0,10(0,07)$ & $0,02(0,05)$ & $-0,11(0,05)^{*}$ \\
\hline Av. retrospectiva (ego) & & & & $0,04(0,05)$ & \\
\hline Av. prospectiva (geral) & & $0,12(0,08)$ & $0,39(0,14)^{*}$ & $-0,03(0,05)$ & $0,03(0,06)$ \\
\hline Av. prospectiva (ego) & & & & $-0,12(0,06)$ & \\
\hline Av. governo & & $0,14(0,02)^{*}$ & $0,38(0,06)^{*}$ & & $-0,50(0,04)^{*}$ \\
\hline Av. economia (geral) & & & $-0,01(0,06)$ & $-0,17(0,04)$ & \\
\hline Av. economia (ego) & & & & $-0,05(0,04)$ & \\
\hline Ascenção classe & & & & & $-0,05(0,08)$ \\
\hline \multicolumn{6}{|l|}{ Avaliação candidato } \\
\hline Simpatia Lula & $-1,03(0,07)^{*}$ & $-0,29(0,01)^{*}$ & & $-0,34(0,05)^{*}$ & \\
\hline Simpatia Serra & & $0,20(0,01)^{*}$ & & & \\
\hline Simpatia Dilma & & & & & $0,00(0,00)$ \\
\hline Simpatia Aécio & & & & & $0,00(0,00)$ \\
\hline \multicolumn{6}{|l|}{ Identificação partidária } \\
\hline PFL & $0,29(0,17)$ & & & & \\
\hline PDS & $0,33(0,17)^{*}$ & & & & \\
\hline PSDB & $-0,15(0,17)$ & $0,51(0,14)^{*}$ & & $0,37(0,12)^{*}$ & $1,49(0,09)^{*}$ \\
\hline PMDB & $0,02(0,14)$ & $0,15(0,14)$ & & & \\
\hline PT & $-0,85(0,17)^{*}$ & $-0,26(0,09)^{*}$ & $-1,50(0,13)^{*}$ & $-0,86(0,09)^{*}$ & $-0,89(0,10)^{*}$ \\
\hline PDT & $-0,69(0,17)^{*}$ & & & & \\
\hline Benefiário PBF & & & $-0,16(0,5)^{*}$ & $-0,11(0,09)$ & $0,15(0,12)$ \\
\hline \multicolumn{6}{|l|}{ Sociodemográficas } \\
\hline Sofisticação & $-0,05(0,03)$ & $0,03(0,03)$ & $-0,05(0,04)$ & $0,05(0,04)$ & $0,12(0,04)^{*}$ \\
\hline Renda & $0,00(0,00)$ & $0,00(0,00)$ & $0,04(0,03)$ & $0,01(0,02)$ & $0,06(0,03)$ \\
\hline Sexo (mulher) & $0,12(0,07)$ & $0,07(0,08)$ & $0,14(0,12)$ & $-0,01(0,07)$ & $0,16(0,07)^{*}$ \\
\hline Cor (branco) & $-0,02(0,07)$ & $0,04(0,08)$ & $0,14(0,12)$ & $0,38(0,08)^{*}$ & $0,15(0,11)$ \\
\hline Escolaridade & $-0,07(0,02)^{*}$ & $-0,00(0,01)$ & $0,04(0,01)^{*}$ & $0,00(0,01)$ & $0,01(0,02)$ \\
\hline $\log ($ Idade $) /$ Idade & $0,09(0,01)$ & $0,11(0,11)$ & $0,09(0,04)$ & $0,15(0,11)$ & $0,32(0,11)^{*}$ \\
\hline Católicos & $0,03(0,01)$ & $0,11(0,12)$ & $0,02(0,19)$ & $-0,08(0,09)$ & $0,08(0,19)$ \\
\hline Evangélicos & $0,11(0,17)$ & $0,24(0,15)$ & $-0,05(0,16)$ & $-0,23(0,12)$ & $-0,11(0,2)$ \\
\hline Região Norte/Centro-Oeste & $0,21(0,10)^{*}$ & $0,07(0,15)$ & $-0,56(0,21)^{*}$ & $0,07(0,12)$ & $0,09(0,12)$ \\
\hline Região Nordeste & $0,05(0,09)$ & $-0,17(0,13)$ & $-0,55(0,18)^{*}$ & $-0,26(0,13)^{*}$ & $-0,47(0,14)^{*}$ \\
\hline Região Sudeste & $0,10(0,11)$ & $-0,07(0,15)$ & $-0,38(0,15)^{*}$ & $0,06(0,12)$ & $0,19(0,12)$ \\
\hline McFadden & 0,32 & 0,48 & 0,32 & 0,16 & 0,21 \\
\hline $\mathbf{N}$ & 1868 & 1931 & 888 & 1335 & 2100 \\
\hline
\end{tabular}

Nota: Erros-padrão robustos entre parênteses.

* Significância estatística a 0,05. 
Em 2002, todavia, as tradicionais variáveis da ciência política retomam o posto de principais ingredientes do caldo eleitoral, destacando-se o personalismo - tendo na afeição aos candidatos deste escrutínio, Lula e Serra, dois determinantes de relevo -, a conjectura dos rumos econômicos e o sentimento acerca das legendas. Nenhum dos coeficientes fatorializados expressou impacto, quando controlados pelos demais elementos explicativos.

A dimensão econômica finalmente adquire proeminência em 2006, junto com o fato de ser beneficiário do Programa Bolsa Família (ocorrência restrita a esse período). A competição renovada entre PT e PSDB parece ter ativado as diferenças no gerenciamento dos negócios públicos desde então. Cumpre ressaltar que, logo depois do primeiro mandato Lula, a ciência política nacional começou a discutir a possibilidade de um realinhamento no país - evento importante para elucidar a alteração das clivagens eleitorais, definindo um novo ciclo político (Hunter e Power, 2007; Nicolau e Peixoto, 2007; Soares e Terron, 2008; Zucco, 2008; Rennó e Cabello, 2010; Singer, 2010; Bohn, 2011; Zucco e Power, 2013; Silva e Rennó, 2015).

Conforme Singer (2010), a modificação da base lulista - que passou a ser constituída por cidadãos com baixos níveis de renda e escolaridade, sobretudo das regiões norte e nordeste do Brasil - expressa uma conversão em duplo sentido: de um lado, a aproximação de grupos sociais mais carentes, beneficiados pelas conquistas materiais provenientes dos programas de governo; de outro, o concomitante afastamento dos setores de classe média por conta da vinculação da liderança e do Partido dos Trabalhadores ao escândalo do "mensalão", em maio de 2005, e de um "cerco político-midiático ao presidente" (Singer, 2010:84).

Especula-se, portanto, que a reorientação econômica promovida pelo PT - baseada na concessão de crédito aos trabalhadores mais pobres, no controle dos preços da cesta básica, no aumento real do salário mínimo e no Programa Bolsa Família - foi notada pelos eleitores e começou a ser um determinante considerável dos pleitos presidenciais desde então. Afinal, a partir daí, os cidadãos tiveram a oportunidade de comparar dois projetos distintos em um sistema bipartidário que contribuiu para estabilizar a competição pelo poder executivo federal.

Senão vejamos: se, antes de 2006, a variável não tinha assumido relevância, de- 
pois desse momento, ela figura como um preditor estatisticamente significativo, tanto em 2010 quanto na acirrada disputa de $2014^{54}$. Por seu turno, os índices sociais e a ampliação do cânone democrático deixaram de entrar no cômputo dos votantes, na medida em que terminaram paulatinamente nas sombras do pragmatismo adotado pela direção do PT pós-2002 ${ }^{55}$. O sentido assembleísta da organização horizontal e da radicalização democrática do partido cedeu lugar a um "reformismo fraco", pautado pelos processos de burocratização ${ }^{56}$. Esse contexto ratifica a noção discutida alhures de que o comportamento e as visões de mundo dos cidadãos se ajustam, em alguma medida, à competição intraelites (Kitscheldt e Hellemans, 1990).

No mais, identificação partidária e desempenho da economia compõem o conjunto de variáveis explicativas de relevo em 2010 e 2014. Entre os fatores sociodemográficos, idade - com os mais velhos afiançando a campanha de Serra (PSDB) - cor, região e escolaridade exibem algum impacto nos respectivos anos.

\subsection{A ideologia e voto}

Daqui em diante, serão testadas no voto as duas especificações de ideologia descritas no capítulo 3: a vertente operacional e a simbólica. As bases sob escrutínio serão o Datafolha/Cultura Política de 1993, e os LAPOP de 2006 e 2014. Assim, teremos uma perspectiva longitudinal das decisões eleitorais entre múltiplos grupamentos ideológicos em três momentos importantes da história nacional: a abertura política, o suposto período da mudança da base petista e o pleito de 2014 - o mais apertado desde a fundação da Sétima República.

Duas notas se fazem necessárias neste instante, contudo. A primeira diz respeito à

${ }^{54}$ No ano de 2014, tivemos a disputa presidencial mais acirrada desde a fundação da Nova República, em 1988. A presidenta Dilma Roussef (PT) superou seu principal adversário, o Senador Aécio Neves (PSDB), por pequena margem de votos $(1,64 \%)$, garantindo assim sua própria reeleição.

${ }^{55} \mathrm{O}$ ano de 2002 marca a reorientação derradeira do Partido dos Trabalhadores (Keck, 2010; Singer, 2010), quando a legenda, após a vitória de Lula no pleito presidencial, confirma a mudança de rumos e divulga a "Carta ao Povo Brasileiro" - documento conhecido pelas concessões feitas para garantir a viabilidade eleitoral e uma suposta governabilidade.

\footnotetext{
${ }^{56}$ Sobre a transformação paulatina do PT, ver Singer (2010).
} 
interpretação dos resultados das urnas, uma vez que insistir em uma visão revisitada de ideologia é também reiterar o caráter simbólico dos comportamentos levados a cabo pelos eleitores. O fato, entretanto, não deve ser entendido mediante o suposto da originalidade. A despeito do grosso da literatura se fiar no exame do desempenho e dos aspectos materiais da decisão do voto, a narrativa de Singer (2010) propõe um caminho alternativo. Isso porque, ao defender a tese do realinhamento, o autor, além de apoiar seu diagnóstico no rearranjo distributivo proporcionado pelo lulismo, preconiza igualmente um sentido ideológico para o evento. Em seu raciocínio, o fenômeno está ancorado na inflexão do suporte do subproletariado - delimitado como "a fração de classe que, embora majoritária, não consegue construir desde baixo as próprias formas de organização"(idem: 83-84) -, que passa a ver em Lula o sistematizador de suas preferências, quais sejam, "a expectativa de um Estado suficientemente forte para diminuir a desigualdade, mas sem ameaçar a ordem estabelecida"(Singer, 2010: 84).

A segunda refere-se à leitura sobre o conceito de realinhamento. Conforme Silva e Rennó (2015), a teoria ganhou força no Brasil em meio a pressupostos que retiram suas características fundamentais. Dos índices centrais atrelados a essa ideia - durabilidade, identificação partidária e contextos críticos -, apenas a última aparece no trabalho de Singer. Há, portanto, necessidade de comprovações empíricas ulteriores que só o transcorrer do tempo pode conceder. De antemão, todavia, considera-se o realinhamento um fenômeno datado historicamente, circunscrito a uma conjuntura na qual a conduta dos eleitores se organiza em torno de sólidas e permanentes identificações partidárias. A configuração política brasileira, com altas taxas de volatilidade e baixo enraizamento com as legendas, não parece se adequar a um diagnóstico do gênero.

Retomando os argumentos centrais, cumpre destacar que se os indivíduos não organizam suas preferências políticas em somente um espectro, arranjos diferenciados de ordenamentos com nexos próprios possivelmente dão ensejo a tipos ideológicos alternativos, os quais não se restringem a arquétipos mutuamente exclusivos. Dito de outro jeito, as intercessões das três dimensões avaliadas podem realçar matizes distintas no quadro ideológico, algo além do binômio esquerda-direita. Visto que as ideologias se manifestam em mais de duas formas, modelos discretos provavelmente captam melhor as minúcias dos posicionamentos políticos do que os modelos contínuos. 
Para testar esses apontamentos, muda-se de enfoque: de uma formulação estatística estimada para comportar exames centrados em itens e com caráter contínuo, a Análise Fatorial, a uma discreta e centrada em pessoas, a Análise de Classes Latentes (ACL) (McCutheon, 1987). A ACL é um modelo estatístico introduzido por Lazarsfeld e Henry (1968) e tem por objetivo a identificação de subgrupos, ou classes, de uma população investigada. Nesse exame, os indivíduos são agrupados com base em posicionamentos políticos manifestados previamente. Em um contexto de demarcação de tipologias, a classe funciona como um termo genérico, a fim de indicar um grupamento em uma dada amostra. O número de categorias realçadas pelo modelo corresponde ao número de clusters delimitado para os participantes.

Assim, se a análise fatorial serve para agrupar itens e apresenta um número elevado de categorias, a ACL procura ordenar pessoas com tendências semelhantes em um construto latente com poucas classes. Ademais, em comparação com a ACL, outras técnicas adequadas a produzir clusters padecem de problemas práticos e teóricos: por um lado, normalmente levam a resultados vagos no que tange à quantidade de possíveis grupos selecionados e a soluções diferentes conforme a prática utilizada; por outro, existe o inconveniente de que os objetos são cotejados entre si em termos de um índice de similaridade baseado nas mesmas variáveis (Hagernaas e Halman, 1989; Lubke e Muthén, 2005; Clark, et al., 2013).

Com efeito, na ACL as relações entre as variáveis observáveis e latentes não são absolutas, nem determinísticas, mas probabilísticas. Ou seja, um indivíduo é designado para ser membro de uma classe com base na sua maior probabilidade de estar nesse grupamento, mesmo que ele seja membro parcial de categorias alternativas. Um postulado importante do modelo, denominado independência local, implica na assertiva que a correlação entre os resultados somente pode ser explicada pela variável latente. Devido a isso, não há correlação residual entre os itens. Formalmente, o método é descrito pela expressão: 


$$
P\left(C=k \mid \mu_{1}, \mu_{2}, \ldots, \mu_{r}\right)=\frac{P(C=k) P\left(\mu_{1} \mid c=k\right) P\left(\mu_{2} \mid C=k\right) \ldots P\left(\mu_{r} \mid C=k\right)}{P\left(\mu_{1}, \mu_{2}, \ldots, \mu_{r}\right)}
$$

Nela, temos que o produto da ACL é a classe estimada de probabilidades de cada indivíduo, chamado de probabilidade posterior, algo análogo ao cálculo dos fatores latentes na análise fatorial (Muthén, 2001). A equação define, portanto, que a probabilidade de ser membro de uma classe $k$, dado um padrão de resposta é igual à probabilidade de estar na classe $k$ multiplicado pelo produto da possibilidade de cada item observável, dividido pela possibilidade de dar uma resposta padrão.

O obstáculo fundamental da ACL, no entanto, reside na incapacidade do modelo em considerar a variação interna dos grupos. Nesse sentido, o Modelo de Mistura de Fatores (Factor Mixture Model) ${ }^{57}$ seria o mais indicado, caso o objetivo fosse capturar essas duas direções. Como, por ora, a ideia é simplesmente escalonar categorias ideológicas, opta-se pela ACL. Assume-se, assim, a tentativa de identificar grupos ou classes de respondentes que tenham padrões de resposta similares nas variáveis observadas. Com o objetivo de facilitar o cálculo e a interpretação do modelo, os preditores estão divididos em três categorias: esquerda, centro e direita.

Novamente, o primeiro passo requer a observação das medidas de ajuste, só que desta vez usadas para identificar a quantidade correta de classes latentes. Seguindo as sugestões de Nylund et all. (2007), estima-se uma série de modelos com número crescente de classes, e aquele com menores valores de AIC e, especialmente, de BIC representará o ajuste ideal dos dados. Nesse sentido, conforme a tabela 17, privilegiam-se os modelos com cinco classes, uma vez que, em todos os anos, os estimadores apresentam valores inferiores nessa configuração.

Em virtude da semelhança dos resultados e da otimização do espaço, somente a ACL do LAPOP de 2014 aparece no corpo do texto, enquanto as demais investigações encontram-se no apêndice. Os coeficientes do modelo estão dispostos na tabela 18. Os va-

${ }^{57} \mathrm{O}$ Factor Mixture Model é flexível para modelar tanto o número de classes como a proporção de indivíduos dentro de uma mesma classe porque combina os postulados da Análise Fatorial com os da ACL (Lubke e Muthén, 2005). 
lores correspondentes aos itens referem-se às probabilidades dos indivíduos se localizarem em uma determinada categoria.

Tabela 17: Medidas comparadas de ajuste dos modelos de LCA

\begin{tabular}{lcccccc}
\hline & \multicolumn{2}{c}{ CP $\mathbf{1 9 9 3}$} & \multicolumn{2}{c}{ LAPOP $\mathbf{2 0 0 6}$} & \multicolumn{2}{c}{ LAPOP $\mathbf{2 0 1 4}$} \\
\hline & AIC & BIC & AIC & BIC & AIC & BIC \\
\hline 1 classe & 31468,10 & 31538,11 & 10878,00 & 10939,22 & 22561,72 & 22646,74 \\
2 classes & 30961,66 & 31107,52 & 10300,11 & 10427,65 & 21658,94 & 21834,28 \\
3 classes & 30561,89 & 30783,59 & 9955,19 & 10149,06 & 21373,82 & 21639,48 \\
4 classes & 30433,77 & 30755,51 & 9889,21 & 10148,41 & 21164,15 & 21531,81 \\
$\mathbf{5}$ classes & $\mathbf{3 0 3 8 2 , 1 0}$ & $\mathbf{3 0 7 3 1 , 3 3}$ & $\mathbf{9 8 6 0 , 1 2}$ & $\mathbf{1 0 1 4 6 , 6 4}$ & $\mathbf{2 1 0 8 5 , 5 0}$ & $\mathbf{2 1 5 2 0 , 1 4}$ \\
\hline 6 classes & 30337,58 & 30786,83 & 9806,18 & 10199,01 & 21031,07 & 21567,7 \\
\hline
\end{tabular}

Nota: $\mathrm{AIC}=$ Akaike Information Criteria $; \mathrm{BIC}=$ Bayesian Information Criteria .

Os membros da classe 1 seguem diretrizes mais brandas em relação à dimensão econômica, são conservadores na maioria dos aspectos sociais, mas entusiastas da participação política. Comparados aos demais, preenchem as lacunas de uma classificação mais ligada ao centro. Na segunda, temos o retrato típico-ideal da esquerda: afeita à intervenção estatal na economia, libertária nos costumes e na forma de atuação o popular, menos ligada à ordem.

Nas categorias subsequentes, residem os de "direita". A classe 3 expõe os conservadores, aqueles que defendem perspectivas pró-mercado, a intervenção estatal nos costumes e adotam posições avessas às greves e manifestações. Nos casos restantes, vemos comunitaristas e liberais $^{58}$. Inicialmente, estão os que advogam o primado do Estado na condução da economia, porém demonstram apoio a um tradicionalismo ligado aos costumes e contrariedade com o ativismo extrainstitucional. Talvez se encaixem nas conceituações de Singer (2010) acima listadas, ou seja, da existência de um bloco ideológico vinculado ao estrato de classe do subproletariado. A seguir, os que acreditam na liberdade como valor máximo. Por isso, mantêm inclinações pró-mercado e prestigiam a autonomia individual em matérias vinculadas aos costumes e à ordem.

\footnotetext{
${ }^{58} \mathrm{Na}$ literatura estadunidense, o correlato dos liberais brasileiros seriam os libertarians. Sobre o assunto, ver Boaz e Kirby (2006), por exemplo.
} 
Tabela 18: Classes latentes extraídas das preferências políticas

\begin{tabular}{|c|c|c|c|c|c|}
\hline \multicolumn{6}{|c|}{ LAPOP 2014} \\
\hline & Classe 1 & Classe 2 & Classe 3 & Classe 4 & Classe 5 \\
\hline \multicolumn{6}{|c|}{ Estado dono empresas } \\
\hline Esquerda & $31,935 \%$ & $60,85 \%$ & $08,02 \%$ & $79,16 \%$ & $18,63 \%$ \\
\hline Centro & $56,09 \%$ & $29,71 \%$ & $06,26 \%$ & $14,63 \%$ & $16,60 \%$ \\
\hline Direita & $11,98 \%$ & $09,44 \%$ & $85,73 \%$ & $06,21 \%$ & $64,77 \%$ \\
\hline \multicolumn{6}{|c|}{ Estado deve reduzir desigualdades } \\
\hline Esquerda & $26,95 \%$ & $71,06 \%$ & $07,82 \%$ & $90,23 \%$ & $10,05 \%$ \\
\hline Centro & $62,06 \%$ & $26,41 \%$ & $06,47 \%$ & $06,40 \%$ & $15,19 \%$ \\
\hline Direita & $10,99 \%$ & $02,53 \%$ & $85,71 \%$ & $03,38 \%$ & 74,76 \\
\hline \multicolumn{6}{|c|}{ Aprova casamento gay } \\
\hline Esquerda & $23,27 \%$ & $74,81 \%$ & $08,28 \%$ & $26,92 \%$ & $43,49 \%$ \\
\hline Centro & $15,15 \%$ & $22,22 \%$ & $02,58 \%$ & $13,86 \%$ & $14,91 \%$ \\
\hline Direita & $61,58 \%$ & $02,96 \%$ & $89,12 \%$ & $59,22 \%$ & $41,60 \%$ \\
\hline \multicolumn{6}{|c|}{ Homens devem ter prioridade empregos } \\
\hline Esquerda & $09,67 \%$ & 51,89 & $02,74 \%$ & $12,51 \%$ & $55,94 \%$ \\
\hline Centro & $24,71 \%$ & $18,77 \%$ & $02,63 \%$ & $19,80 \%$ & $23,54 \%$ \\
\hline Direita & $65,62 \%$ & $29,35 \%$ & $94,63 \%$ & $67,70 \%$ & $20,52 \%$ \\
\hline \multicolumn{6}{|c|}{ Aprova participação em manifestações } \\
\hline Esquerda & $76,77 \%$ & $69,68 \%$ & $10,09 \%$ & $15,40 \%$ & $71,47 \%$ \\
\hline Centro & $20,31 \%$ & $30,32 \%$ & $05,84 \%$ & $13,35 \%$ & $16,04 \%$ \\
\hline Direita & $02,92 \%$ & $0 \%$ & $84,07 \%$ & $71,25 \%$ & $12,49 \%$ \\
\hline \multicolumn{6}{|c|}{ Aprova bloqueio ruas } \\
\hline Esquerda & $45,44 \%$ & $93,11 \%$ & $02,39 \%$ & $12,49 \%$ & $47,13 \%$ \\
\hline Centro & $38,79 \%$ & $06,89 \%$ & $09,64 \%$ & $16,04 \%$ & $22,30 \%$ \\
\hline Direita & $15,77 \%$ & $0 \%$ & $87,97 \%$ & $71.47 \%$ & $30,56 \%$ \\
\hline
\end{tabular}

Nota: Os coeficientes de cada questão são a probabilidade estimada de cada resposta para os membros das respectivas classes latentes.

\subsection{Perfis políticos e sociodemográficos das categorias ideológicas}

Constatadas cinco categorias ideológicas distintas, identificamos a diferença de perfis associadas a cada uma delas. Segue-se com as mesmas bases de dados, nas quais se especifica as principais questões de posição atinentes às dimensões consideradas anteriormente. Desta vez, no entanto, utiliza-se novamente a técnica de análise fatorial para criar os coeficientes dos respondentes nas áreas econômica, social e relativa à participação 
popular. Assim, divide-se os indivíduos nas três temáticas em tercis baseados nos 33os e nos 67 os percentis da distribuição das dimensões, com os valores mais altos associados a posicionamentos conservadores.

Os segmentos no menor tercil de todas as dimensões serão classificados como de esquerda e os posicionados no maior tercil herdarão o rótulo de conservadores. Pessoas com crenças cruzadas, isto é, com preferências distintas ao longo das matérias observadas, receberão a denominação de liberais ou comunitaristas, dependendo da direção de suas inclinações concernentes ao modelo de ACL. Logo, os liberais figuram no 67o quartil em assuntos econômicos e no $33 \mathrm{o}$ em enunciados referentes aos costumes e à ordem; enquanto os comunitaristas guardam posições inversas. Por último, os moderados, ou seja, situados no percentil do meio em todas as situações.

A figura 11 apresenta a proporção das categorias ideológicas nos anos investigados. Cumpre salientar a natureza mais ilustrativa do que comparativa do gráfico, já que as perguntas levantadas nos questionários não possuem configurações semelhantes e, portanto, a proporção das classes em destaque pode ser um simples atributo da formatação dos itens selecionados e não da efetiva mudança ideológica dos cidadãos brasileiros ao longo do tempo.

Figura 11: Proporção das categorias ideológicas nos anos de 1993, 2006, 2014.

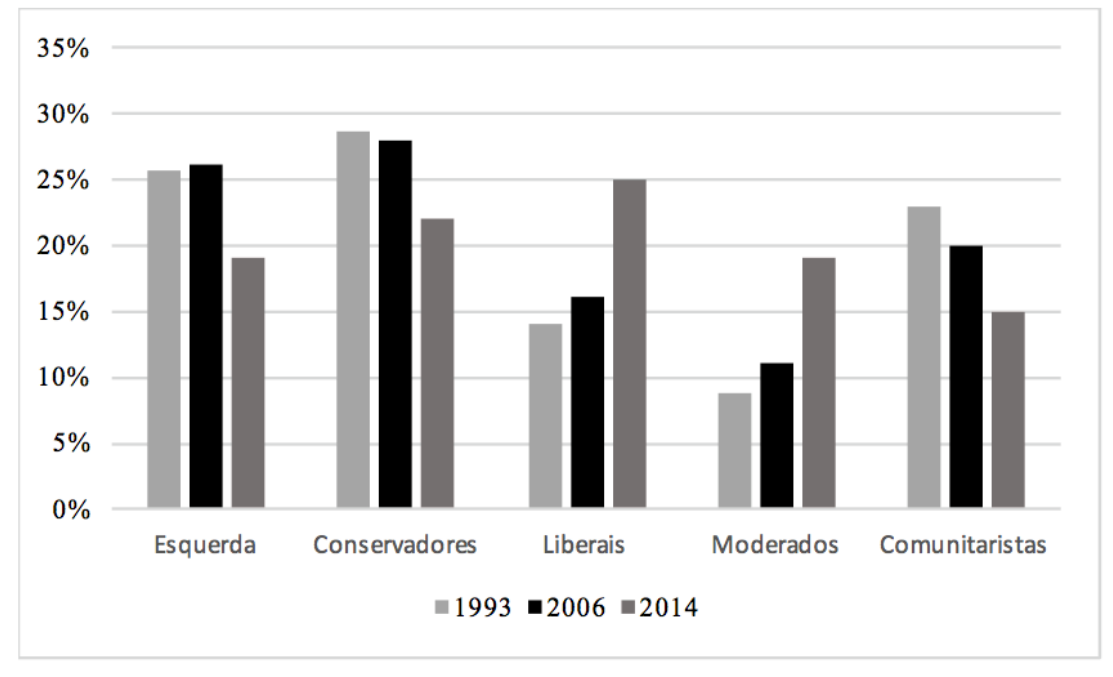

Nota: Gráfico estimado com dados do Datafolha/Cultura Política 1993, LAPOP 2006 e LAPOP 2014. 
Quanto aos perfis políticos, é interessante fazer uma breve comparação das categorias inferidas a partir de técnicas latentes e o autoposicionamento ideológico, com o fito de verificar possíveis desajustes. Nesse ponto, a escala unidimensional foi dividida em 5 segmentos: esquerda, centro-esquerda, centro, centro-direita e direita. As figuras 12, 13 e 14 dispõem o cruzamento das duas variáveis, conforme os anos trabalhados.

Figura 12: Cruzamento das vertentes operacional e simbólica da ideologia em 1993.

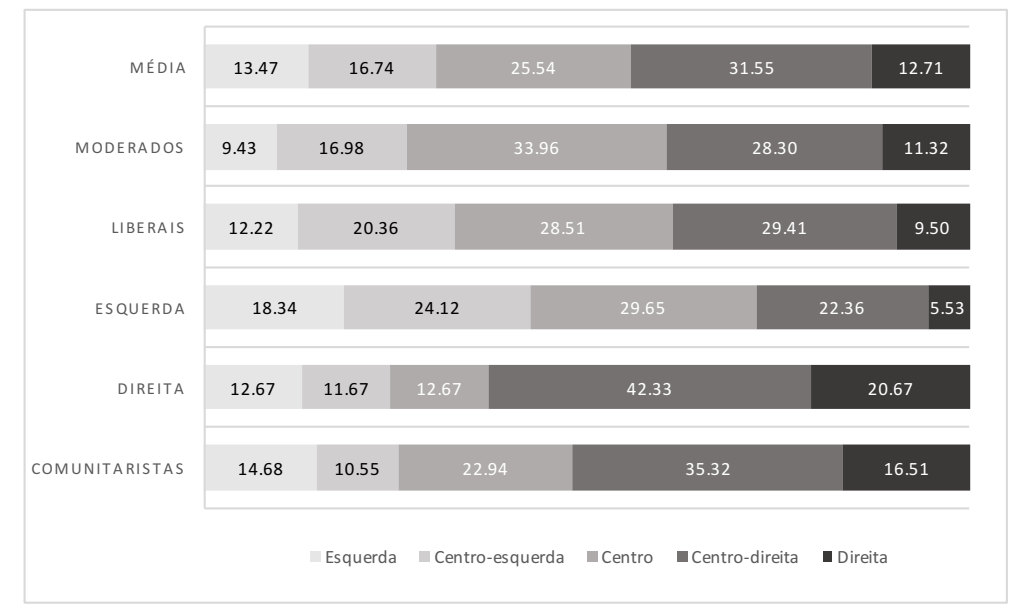

Figura 13: Cruzamento das vertentes operacional e simbólica da ideologia em 2006.



Novamente, nota-se a diferença de entendimentos acerca do contínuo, haja vista que indivíduos com crenças semelhantes se colocam de maneira distinta no espectro espacial. Salvo em 1993, em todos os anos o signo do centro ganhou na preferência média, seguido de seus afiliados: a centro-direita e a centro-esquerda. Se os extremos guardam menos adeptos, o extremo da direita é mais popular do que o da esquerda. 
Figura 14: Cruzamento das vertentes operacional e simbólica da ideologia em 2014.

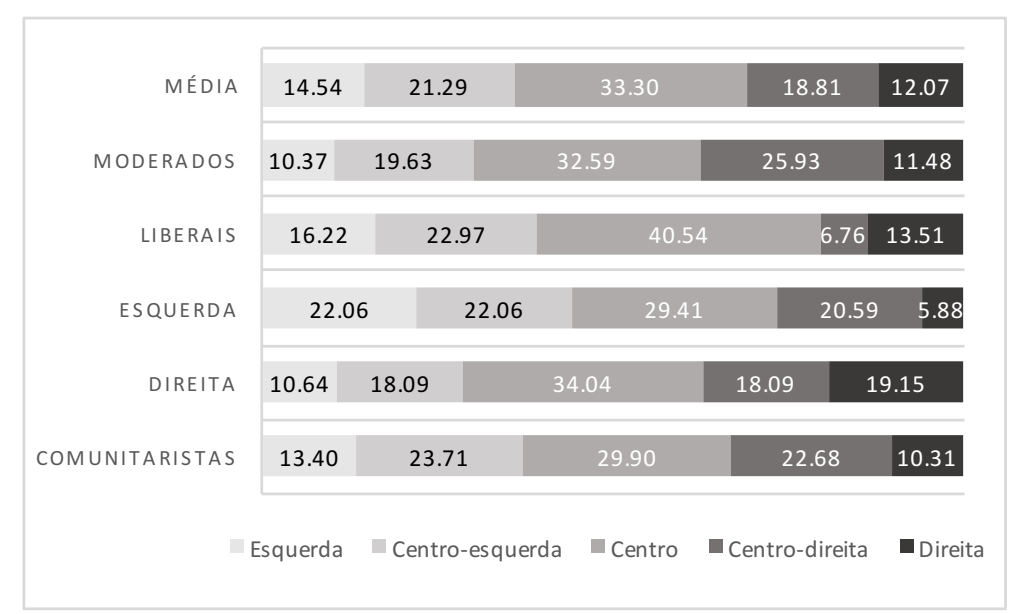

Moderados, liberais e comunistaristas costumam preferir os dísticos de centro e centro-direita. Os progressistas usam menos as declarações à direita, ainda que o façam de maneira significativa. Os conservadores, por sua vez, apresentam posicionamentos substanciais em relação aos limites da escala e na centro-direita. Se pensarmos que esquerdistas e conservadores configuram tipos "puros"- ou seja, não alternam suas crenças entre as diferenças dimensões - faz mesmo sentido a maior propensão de se identificarem com as extremidades da medida.

Em relação à identificação partidária (figuras 15, 16, 17), o primeiro ponto a se destacar é o aumento do desalinhamento dos cidadãos com as principais legendas. A média dos que não simpatizam com nenhum partido subiu em quase $50 \%$ do início dos anos 1990 até 2006. Se em 1993 o PMDB figurava como o preferido dos eleitores, a partir de 2006 o PT assume o posto de favorito.

Os comunitaristas parecem ter trocado a predileção - antes pelo PMDB e, após 2006, pelo PT. Os liberais oscilaram entre os períodos, tornando difícil um diagnóstico exato. De resto, o esperado: moderados e esquerdistas se sentem mais representados pelo PT e os conservadores pelo PMDB. 
Figura 15: Identificação partidária dos grupamentos em 1993.

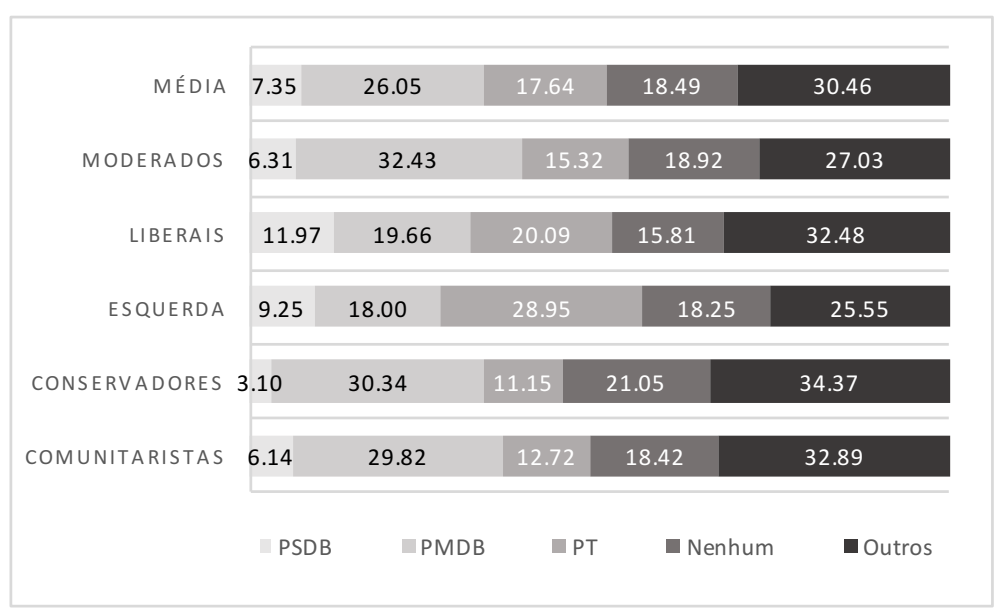

Figura 16: Identificação partidária dos grupamentos em 2006.

\begin{tabular}{|c|c|c|c|c|}
\hline \multirow[b]{2}{*}{ MODERADOS } & $3.02 \quad 16.04$ & \multicolumn{2}{|r|}{69.06} & 11.89 \\
\hline & $2.49 \quad 19.40$ & & 70.15 & 7.96 \\
\hline LIBERAIS & 8.064 .84 & & 79.03 & 8.06 \\
\hline ESQUERDA & 23.81 & & 56.19 & 14.29 \\
\hline CONSERVADORES & 16.334 .08 & & 67.35 & 12.24 \\
\hline COMUNITARISTAS & 4.4810 .45 & & .16 & 17.91 \\
\hline & PMDB & PT & Nenhum & Outros \\
\hline
\end{tabular}

Figura 17: Identificação partidária dos grupamentos em 2014.

\begin{tabular}{|c|c|c|c|c|}
\hline \multirow[b]{2}{*}{ MODERADOS } & $3.02 \quad 16.04$ & \multicolumn{2}{|r|}{69.06} & 11.89 \\
\hline & $2.49 \quad 19.40$ & & 70.15 & 7.96 \\
\hline LIBERAIS & 8.064 .84 & & 79.03 & 8.06 \\
\hline ESQUERDA & $5.71 \quad 23.81$ & & 56.19 & 14.29 \\
\hline CONSERVADORES & $16.33 \quad 4.08$ & & 67.35 & 12.24 \\
\hline COMUNITARISTAS & 4.4810 .45 & & 67.16 & 17.91 \\
\hline & $\mathrm{PMDB}$ & PT & Nenhum & Outros \\
\hline
\end{tabular}


Os perfis demográficos associados estão organizados nas tabelas 19, 20 e 21. Calculouse os coeficientes da variável dependente em regressões probit, separando as classes ideológicas segundo formatos dummy. A regressão probit permite estimar verificar quais as variáveis têm maior influência na estruturação dos grupos ideológicos. Os regressores em evidência são: religião, sexo (feminino), idade, renda, cor, região (com o "sul" como categoria de referência), identificação partidária e sofisticação política. Os itens foram operacionalizados de maneira similar - exceto o partidarismo, já que na base de 1993 a simpatia com outras legendas, além do PT , exibe proporções significativas.

Tabela 19: Perfis associados às categorias ideológicas (CP 1993)

\begin{tabular}{|c|c|c|c|c|c|}
\hline & Esquerda & Conservadores & Moderados & Liberais & Comunitaristas \\
\hline Católicos & $-0,07(0,09)$ & $-0,20(0,09)^{*}$ & $-0,03(0,11)$ & $0,10(0,10)$ & $0,16(0,10)$ \\
\hline Evangélicos & $-0,09(0,16)$ & $0,00(0,16)$ & $-0,07(0,20)$ & $-0,43(0,21)^{*}$ & $0,32(0.16)^{*}$ \\
\hline Sexo (mulher) & $0,16(0,07)^{*}$ & $-0,12(0,07)$ & $0,07(0,08)$ & $0,03(0,07)$ & $-0,15(0,07)^{*}$ \\
\hline Log(idade) & $-0,19(0,08)^{*}$ & $0,26(0,08)^{*}$ & $-0,08(0,10)$ & $-0,23(0,09)^{*}$ & $0,10(0,08)$ \\
\hline Renda & $0.03(0,02)$ & $0,04(0,02)$ & $0,01(0,03)$ & $0,04(0,03)$ & $-0,05(0.02)^{*}$ \\
\hline Cor (brancos) & $-0,10(0,07)$ & $0,07(0,07)$ & $0,07(0,08)$ & $-0,03(0,07)$ & $0,10(0,07)$ \\
\hline Escolaridade & $0,08(0,02)^{*}$ & $-0,18(0,03)^{*}$ & $0,00(0,03)$ & $0,09(0.02)^{*}$ & $-0,14(0,02)^{*}$ \\
\hline Sudeste & $0,19(0,10)$ & $-0,18(0,10)$ & $-0,23(0,11)^{*}$ & $-0,14(0,09)$ & $0,08(0,10)$ \\
\hline Nordeste & $-0,06(0,11)$ & $0,09(0,11)$ & $-0,30(0,12)^{*}$ & $-0,37(0,11)^{*}$ & $0,32(0,11)^{*}$ \\
\hline Centro-Oeste/Norte & $0,03(0,13)$ & $0,07(0,12)$ & $-0,22(0,15)$ & $-0,43(0,14)^{*}$ & $0,36(0,12)^{*}$ \\
\hline Id. partidária (PFL) & $-0,35(0,17)^{*}$ & $0,23(0,15)$ & $0,12(0,18)$ & $-0,22(0,18)$ & $-0,01(0,15)$ \\
\hline Id. partidária (PDS) & $-0,08(0,16)$ & $0,17(0,16)$ & $-0,31(0,20)$ & $-0,22(0,17)$ & $0,03(0,16)$ \\
\hline Id. partidária (PSDB) & $-0,09(0,17)$ & $-0,41(0,21)$ & $-0,09(0,17)$ & $0,09(0,17)$ & $0,15(0,17)$ \\
\hline Id. partidária (PMDB) & $-0,28(0,13)^{*}$ & $0,00(0,13)$ & $-0,12(0,16)$ & $-0,16(0,14)$ & $0,00(0,13)$ \\
\hline Id. partidária (PT) & $-0,02(0,14)$ & $-0,03(0,15)$ & $-0,51(0,24)^{*}$ & $-0,14(0,15)$ & $-0,05(0,14)$ \\
\hline Id. partidária (PDT) & $-0,04(0,16)$ & $0,15(0,16)$ & $-0,03(0,19)$ & $-0,16(0,17)$ & $0,02(0,16)$ \\
\hline Sofisticação & $0,13(0,03)^{*}$ & $-0,15(0,03)^{*}$ & $0,03(0,03)$ & $0,03(0,03)$ & $-0,04(0,03)$ \\
\hline McFadden & 0,07 & 0,02 & 0,02 & 0,05 & 0,06 \\
\hline
\end{tabular}

Nota: Erros-padrão robustos entre parênteses.

* Significância estatística a 0,05.

De modo geral, perfilam as fileiras progressistas: mulheres, indivíduos que não sejam evangélicos e possuam escolaridade avançada. Outros aspectos como a rejeição dos dísticos de direita, ou morar fora das regiões Centro-Oeste ou Norte do país - quando comparados aos habitantes do Sul - são distintivos da esquerda nas pesquisas de 1993 e 
2006, respectivamente. No bloco dos conservadores, estão os homens mais velhos, com índices reduzidos de educação formal e superiores de renda. Em 1993, incluem-se ainda neste rol a preferência pelo Partido da Frente Liberal (PFL) e aproximação dos católicos a esta tendência em 2014. Para terminar de descrever os grupos tradicionais da literatura especializada, os moderados em 1993 exprimem os antipáticos ao projeto petista e os residentes nas regiões Centro-Oeste, Norte e Sul. Em contraste, no ano de 2014, a camada notabiliza-se pela identificação com o PT e pela composição entre pessoas com idade mais avançada.

Tabela 20: Perfis associados às categorias ideológicas (LAPOP 2006)

\begin{tabular}{lccccc}
\hline & Esquerda & Conservadores & Moderados & Liberais & Comunitaristas \\
\hline Católicos & $-0,14(0.12)$ & $0,18(0,16)$ & $0,15(0,12)$ & $-0,12(0,15)$ & $0,15(0,19)$ \\
Evangélicos & $-0,45(0,17)^{*}$ & $0,21(0,19)$ & $0,23(0,14)$ & $-0,08(0,18)$ & $0,41(0,22)^{*}$ \\
Sexo (mulher) & $0,01(0,09)$ & $-0,29(0.10)^{*}$ & $-0,06(0,08)$ & $0,19(0,11)$ & $-0,11(0,12)$ \\
Log(idade) & $-0.01(0,03)$ & $0,01(0,04)$ & $-0,05(0,03)$ & $-0,05(0,04)$ & $0,11(0,04)^{*}$ \\
Renda & $0,00(0,02)$ & $-0,01(0,02)$ & $0,02(0,02)$ & $-0,04(0,03)$ & $0,05(0,03)$ \\
Cor (brancos) & $-0,11(0,10)$ & $0,11(0,11)$ & $0,05(0.09)$ & $0.10(0,12)$ & $-0,05(0,13)$ \\
Escolaridade & $0,05(0,01)^{*}$ & $-0,06(0,01)^{*}$ & $-0,00(0,01)$ & $0,00(0,01)$ & $-0,00(0,01)$ \\
Sudeste & $-0,11(0,13)$ & $0,35(0,17)^{*}$ & $-0,06(0,12)$ & $0,19(0,17)$ & $0,46(0,26)$ \\
Nordeste & $-0,26(0,16)$ & $0,33(0,19)$ & $-0,09(0,14)$ & $-0,04(0,20)$ & $0,10(0,02)^{*}$ \\
Centro-Oeste/Norte & $-0,40(0,19)^{*}$ & $0,48(0,21)^{*}$ & $-0,23(0,16)$ & $-0.05(0,22)$ & $0,49(0,30)$ \\
Id. partidária (PT) & $0,09(0,09)$ & $-0.04(0,10)$ & $0,02(0,08)$ & $-0,03(0,11)$ & $0,04(0,12)$ \\
Sofisticação & $0.00(0,04)$ & $-0,08(0,05)$ & $0,03(0,04)$ & $-0,01(0,05)$ & $0,11(0,06)$ \\
McFadden & 0,04 & 0,07 & 0,02 & 0,03 & 0,08 \\
\hline
\end{tabular}

Nota: Erros-padrão robustos entre parênteses.

* Significância estatística a 0,05.

Do lado dos grupamentos com preferências combinadas através das dimensões, os comunitaristas são representados por homens pobres, evangélicos, normalmente cidadãos do Norte, Nordeste ou Centro-Oeste, com baixos níveis de escolaridade e sofisticação política. Os liberais concentram-se entre os jovens escolarizados e sofisticados do Sudeste e do Sul. Em 2014, o perfil desse grupamento ajusta-se ainda aos opositores do PT. 
Tabela 21: Perfis associados às categorias ideológicas (LAPOP 2014)

\begin{tabular}{lccccc}
\hline & Esquerda & Conservadores & Moderados & Liberais & Comunitaristas \\
\hline Católicos & $0,18(0,11)$ & $-0,15(0,10)$ & $0,12(0,12)$ & $-0,13(0,11)$ & $0,02(0,11)$ \\
Evangélicos & $-0,30(0,13)^{*}$ & $-0,11(0,13)$ & $0,16(0,14)$ & $-0,10(0,13)$ & $-0,06(0,14)$ \\
Sexo (mulher) & $0,18(0,08)^{*}$ & $-0,37(0,09)^{*}$ & $-0,00(0,10)$ & $0,02(0,09)$ & $-0,05(0,09)$ \\
Log(Idade) & $-0,15(0,11)$ & $0,18(0,11)$ & $0,24(0,12)^{*}$ & $-0,35(0,12)^{*}$ & $-0,20(0,12)$ \\
Renda & $-0,00(0,01)$ & $-0,01(0,01)$ & $0,01(0,01)$ & $0,00(0,01)$ & $-0,01(0,01)$ \\
Cor (branco) & $0,04(0,09)$ & $0,12(0,10)$ & $0,05(0,11)$ & $0,04(0,10)$ & $-0,06(0,10)$ \\
Escolaridade & $-0,02(0,01)$ & $0,02(0,01)$ & $-0,01(0,01)$ & $0,03(0,01)$ & $-0,02(0,01)^{*}$ \\
Sudeste & $-0,12(0,13)$ & $0,42(0,15)^{*}$ & $-0,24(0,14)$ & $-0,20(0,15)$ & $-0,54(0,18)^{*}$ \\
Nordeste & $-0,22(0,15)$ & $0,64(0,16)^{*}$ & $-0,17(0,16)$ & $-0,07(0,15)$ & $0,46(0,19)^{*}$ \\
Centro-Oeste/Norte & $-0,05(0,14)$ & $0,42(0,15)^{*}$ & $-0,17(0,15)$ & $-0,16(0,13)$ & $0,64(0,17)^{*}$ \\
Id. partidária (PT) & $0,02(0,08)$ & $-0,10(0,09)$ & $0,04(0,10)$ & $-0,21(0,09)^{*}$ & $0,04(0,09)$ \\
Sofisticacao & $0,06(0,09)$ & $0,02(0,10)$ & $-0,07(0,10)$ & $0,08(0,10)$ & $0,03(0,10)$ \\
McFadden & 0,16 & 0,06 & 0,05 & 0,06 & 0,04 \\
\hline
\end{tabular}

Nota: Erros-padrão robustos entre parênteses.

* Significância estatística a 0,05.

\subsection{O impacto das categorias ideológicas no voto}

A ideologia nunca deixou de fazer parte dos modelos de comportamento eleitoral, conforme citado ao longo da tese. Desde o início dos anos 1990, os cientistas políticos debatem o efeito da variável no voto presidencial, com achados quase sempre significativos. Embora o regressor em geral tenha se mostrado um bom preditor do sufrágio, as dúvidas pairam sobre confiabilidade da escala unidimensional. Afinal, como acreditar em um questionamento no qual os respondentes têm noção limitada?

Nos capítulos 2 e 3, apontou-se a confusão terminológica, a natureza simbólica do reconhecimento dos vocábulos esquerda e direita e uma solução alternativa: a instrumentalização de uma medida latente, formada por questões presentes no cotidiano dos cidadãos comuns, revelando, dessa maneira, opiniões mais acuradas a respeito do posicionamento ideológico. Nesta seção, portanto, o objetivo é verificar o impacto dos cinco grupamentos alternativos supracitados - esquerdistas, conservadores, liberais, comunitaristas e moderados - na escolha do chefe do executivo federal. Novamente, recorre-se às regressões binárias probit para deslindar o atual cenário. 
Como variável dependente, a decisão do voto no segundo turno das três eleições, com as abstenções excluídas dos modelos de análise e, desta vez, com os candidatos à direita do espectro político enquanto referência. Dessa forma, contamos de outra maneira a história da mudança das bases eleitorais em tempos recentes. A narrativa, essencialmente calcada em componentes materiais ou personalista - salvo nas teorizações de Singer (2010), embora sem comprovações empíricas -, pode então ganhar novos elementos, vinculados aos sistemas de crenças compartilhados pelos cidadãos.

As variáveis independentes acompanham, destarte, a configuração das regressões expostas na segunda seção, onde foi ponderado o papel dos issues na deliberação das preferências eleitorais. A única novidade é a inclusão dos grupos ideológicos nos cálculos de estimação dos coeficientes. Na tabela 22 estão dispostos os efeitos marginais de todos os regressores, bem como a comparação entre os enquadramentos unidimensionais e multidimensionais da ideologia. No receituário unidimensional, no entanto, os valores mais altos indicam a identificação com o signo da esquerda.

As diferenças não se apresentam tão robustas quando comparamos as medidas de ajuste, já que os valores do McFadden pseudo- $\mathrm{R}^{2}$ são bastante próximos nos modelos observados - com 0,24 da regressão multidimensional contra 0,23 da unidimensional em 1993; 0,30 e 0,28 em 2006; e 0,38 e 0,28 em 2014. Os efeitos marginais dos preditores exibem um quadro um tanto dessemelhante, contudo.

Começando por 1989, as variáveis em pauta mostram-se estatisticamente significativas, acompanhadas da sofisticação política e das identificações com o PT, PSDB e o Partido Democrático Trabalhista. Quando adotamos a mensuração operacional, captamos de modo mais apurado os matizes da força com que os sistemas ideológicos influenciam o jogo político. Não somente os esquerdistas, cotejados aos conservadores e às demais variáveis controle, mas também os liberais tinham, respectivamente, entre $24 \%$ e $13 \%$ e $17 \%$ e $6 \%$ de chances de votarem em Lula (figura 18). 
Tabela 22: Categorias ideológicas e voto (CP 1989)

\begin{tabular}{|c|c|c|}
\hline & Modelo multidimensional & Modelo unidimensional \\
\hline \multicolumn{3}{|l|}{ Categorias ideológicas } \\
\hline Esquerda & $0,17(0,06)^{*}$ & $0,03(0,00)^{*}$ \\
\hline Comunitaristas & $0,06(0,05)$ & \\
\hline Liberais & $0,16(0,05)^{*}$ & \\
\hline Moderados & $0,10(0,05)$ & \\
\hline \multicolumn{3}{|l|}{ Identidade partidária } \\
\hline Id. partidária (PFL) & $-0,19(0,07)^{*}$ & $-0,17(0,07)^{*}$ \\
\hline Id. partidária (PDS) & $-0,09(0,07)$ & $-0,09(0,07)$ \\
\hline Id. partidária (PSDB) & $0,15(0,08)$ & $0,15(0,08)$ \\
\hline Id. partidária (PMDB) & $0,01(0,06)$ & $0,01(0,06)$ \\
\hline Id. partidária $(\mathrm{PT})$ & $0,49(0,05)^{*}$ & $0,47(0,05)^{*}$ \\
\hline Id. partidária (PDT) & $0,42(0,06)^{*}$ & $0,40(0,06)^{*}$ \\
\hline \multicolumn{3}{|c|}{ Variáveis sociodemográficas } \\
\hline Sudeste & $-0,04(0,05)$ & $-0,04(0,05)$ \\
\hline Nordeste & $0,00(0,05)$ & $-0,01(0,05)$ \\
\hline Centro-Oeste/Norte & $-0,00(0,06)$ & $0,00(0,07)$ \\
\hline Sexo (mulher) & $0,07(0,03)^{*}$ & $0,06(0,03)$ \\
\hline $\log ($ Idade $)$ & $-0,08(0,04)$ & $-0,07(0,04)$ \\
\hline Católicos & $0,06(0,05)$ & $0,05(0,05)$ \\
\hline Evangélicos & $0,20(0,08)^{*}$ & $0,18(0,09)^{*}$ \\
\hline Cor (branco) & $-0,01(0,03)$ & $-0,02(0,03)$ \\
\hline Renda & $0,00(0,01)$ & $-0,00(0,01)$ \\
\hline Sofisticação & $0,03(0,01)^{*}$ & $0,04(0,01)^{*}$ \\
\hline McFadden & 0,22 & 0,22 \\
\hline $\mathbf{N}$ & 1866 & 1866 \\
\hline
\end{tabular}

Nota: Erros-padrão robustos entre parênteses.

* Significância estatística a 0,05. 
Figura 18: Efeitos dos preditores significativos do voto em 1989.

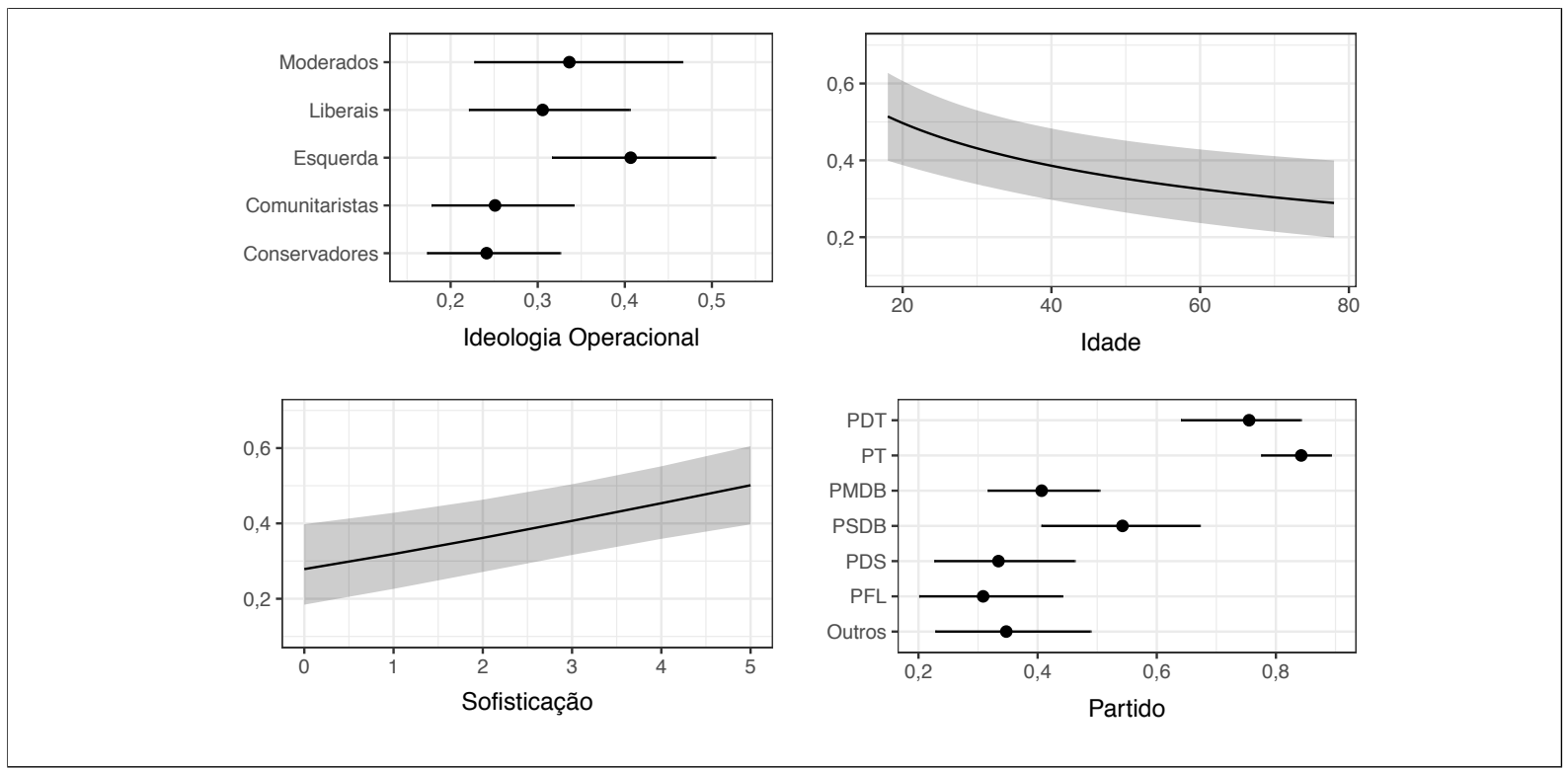

Em 2006 (tabela 23), a ideologia simbólica sequer demonstra significância estatística, ao passo que a vertente operacional expressa uma probabilidade entre $15 \%$ e $7 \%$ dos esquerdistas renovarem suas esperanças na liderança petista e - a novidade - dos comunitaristas igualmente depositarem suas fichas no candidato incumbente, respondendo com taxas entre $15 \%$ e $9 \%$ (figura 19). Com a inclusão da variável multifacetada, além da avaliação positiva de governo e da simpatia com o PT, a avaliação do governo então se destaca.

Figura 19: Efeitos dos preditores significativos do voto em 2006.

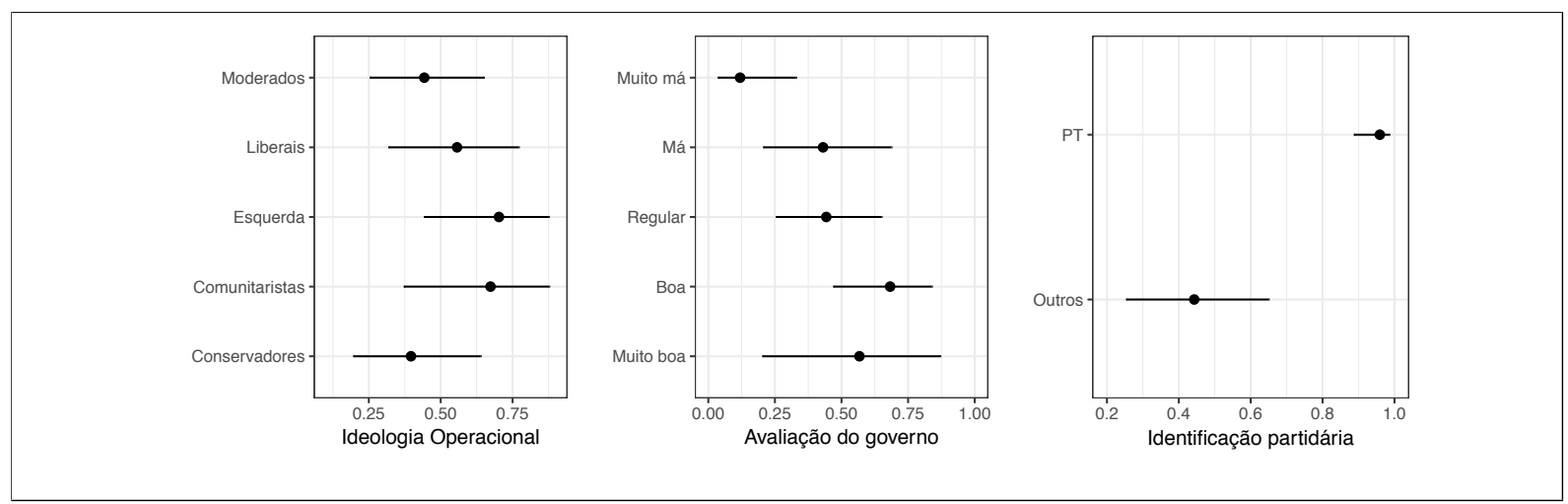


Tabela 23: Categorias ideológicas e voto (LAPOP 2006)

\begin{tabular}{lcc}
\hline & Modelo multidimensional & Modelo unidimensional \\
\hline Categorias ideológicas & $0,10(0,03)^{*}$ & $0,00(0,00)$ \\
Esquerda & $0,09(0,03)^{*}$ & \\
Comunitaristas & $0,05(0,04)$ & \\
Liberais & $0,00(0,04)$ & \\
Moderados & & $-0,00(0,01)$ \\
Avaliação de desempenho & $-0,00(0,01)$ & $-0,00(0,02)$ \\
Avaliação economia (sociotrópica) & $-0,01(0,02)$ & $-0,08(0,01)$ \\
Avaliação economia (egotrópica) & $-0,07(0,01)^{*}$ & \\
Avaliação governo & $0,00(0,02)$ & $-0,08(0,04)$ \\
Avaliação retrospectiva (egotrópica) & $-0,08(0,04)$ & \\
Avaliação prospectiva (egotrópica) & & $0,33(0,03)^{*}$ \\
Identidade partidária & $0,33(0,03)^{*}$ & \\
Id. partidária (PT) & & $-0,02(0,04)$ \\
Variáveis sociodemográficas & $-0,03(0,05)$ & $-0,06(0,04)$ \\
Sudeste & $0,04(0,05)$ & $-0,01(0,00)$ \\
Nordeste & $0,06(0,04)$ & $-0,00(0,01)$ \\
Centro-Oeste/Norte & $-0,00(0,03)$ & $0,07(0,04)$ \\
Sexo (mulher) & $-0,05(0,04)$ & $0,00(0,03)$ \\
Log(Idade) & $0,01(0,04)$ & $-0,01(0,01)$ \\
Católicos & $-0,00(0,06)$ & \\
Evangélicos & $-0,06(0,03)$ & \\
Cor (branco) & $-0,01(0,00)$ & \\
Renda & $-0,01(0,01)$ & \\
Sofisticação & 0,35 & \\
McFadden & 888 & \\
$\mathbf{N}$ & & \\
\hline Nota: & & \\
\hline & & \\
\hline
\end{tabular}

Nota: Erros-padrão robustos entre parênteses.

* Significância estatística a 0,05.

Análogo a 2006, em 2014 (tabela 24) o sentido simbólico do autoposionamento distorce os efeitos da ideologia, apresentandos pouca relevância quando controlado pelos outros fatores considerados. A medida operacional revela a continuidade da aprovação dos comunitaristas e da esquerda ao comando petista. Ambos figuram com $13 \%$ e $5 \%$ e $12 \%$ e $6 \%$ (figura 19) de chances de votar em Dilma no segundo turno. De resto, a identificação com o PT, o sexo, avaliação de Dilma e a idade compõem o perfil dos 
eleitores da presidenta posteriormente impedida.

Tabela 24: Categorias ideológicas e voto (LAPOP 2014)

\begin{tabular}{|c|c|c|}
\hline & Modelo multidimensional & Modelo unidimensional \\
\hline \multicolumn{3}{|l|}{ Categorias ideológicas } \\
\hline Esquerda & $0,09(0,03)^{*}$ & $0,00(0,00)$ \\
\hline Comunitaristas & $0,09(0,04)^{*}$ & \\
\hline Liberais & $0,02(0,05)$ & \\
\hline Moderados & $0,07(0,04)$ & \\
\hline \multicolumn{3}{|l|}{ Avaliação de desempenho } \\
\hline Avaliação retrospectiva (sociotrópica) & $-0,04(0,02)$ & $-0,03(0,02)$ \\
\hline Avaliação retrospectiva (egotrópica) & $-0,03(0,02)$ & $-0,03(0,02)$ \\
\hline Avaliação Dilma & $0,04(0,01)^{*}$ & $0,05(0,01)^{*}$ \\
\hline Ascenção de classe & $0,00(0,03)$ & $-0,00(0,03)$ \\
\hline \multicolumn{3}{|l|}{ Identificação partidária } \\
\hline Id. partidária $(\mathrm{PT})$ & $0,49(0,03)^{*}$ & $0,49(0,03)^{*}$ \\
\hline \multicolumn{3}{|l|}{ Variáveis sociodemográficas } \\
\hline Sudeste & $-0,01(0,05)$ & $-0,00(0,05)$ \\
\hline Nordeste & $-0,00(0,04)$ & $-0,00(0,04)$ \\
\hline Centro-Oeste/Norte & $0,07(0,04)$ & $0,07(0,04)$ \\
\hline Mulher & $0,09(0,03)^{*}$ & $0,09(0,03)^{*}$ \\
\hline Log(Idade) & $0,03(0,01)^{*}$ & $0,02(0,03)$ \\
\hline Católicos & $0,06(0,03)$ & $0,08(0,03)^{*}$ \\
\hline Evangélicos & $0,03(0,04)$ & $0,04(0,03)$ \\
\hline Beneficiário PBF & $0,07(0,05)$ & $0,08(0,03)^{*}$ \\
\hline Renda & $-0,01(0,01)$ & $-0,01(0,01)$ \\
\hline Cor & $0,01(0,03)$ & $0,01(0,03)$ \\
\hline Sofisticação & $-0,01(0,03)$ & $-0,01(0,03)$ \\
\hline McFadden & 0,38 & 0,28 \\
\hline $\mathbf{N}$ & 744 & 744 \\
\hline
\end{tabular}

Nota: Erros-padrão robustos entre parênteses.

* Significância estatística a 0,05. 
Figura 20: Efeitos dos preditores significativos do voto em 2014

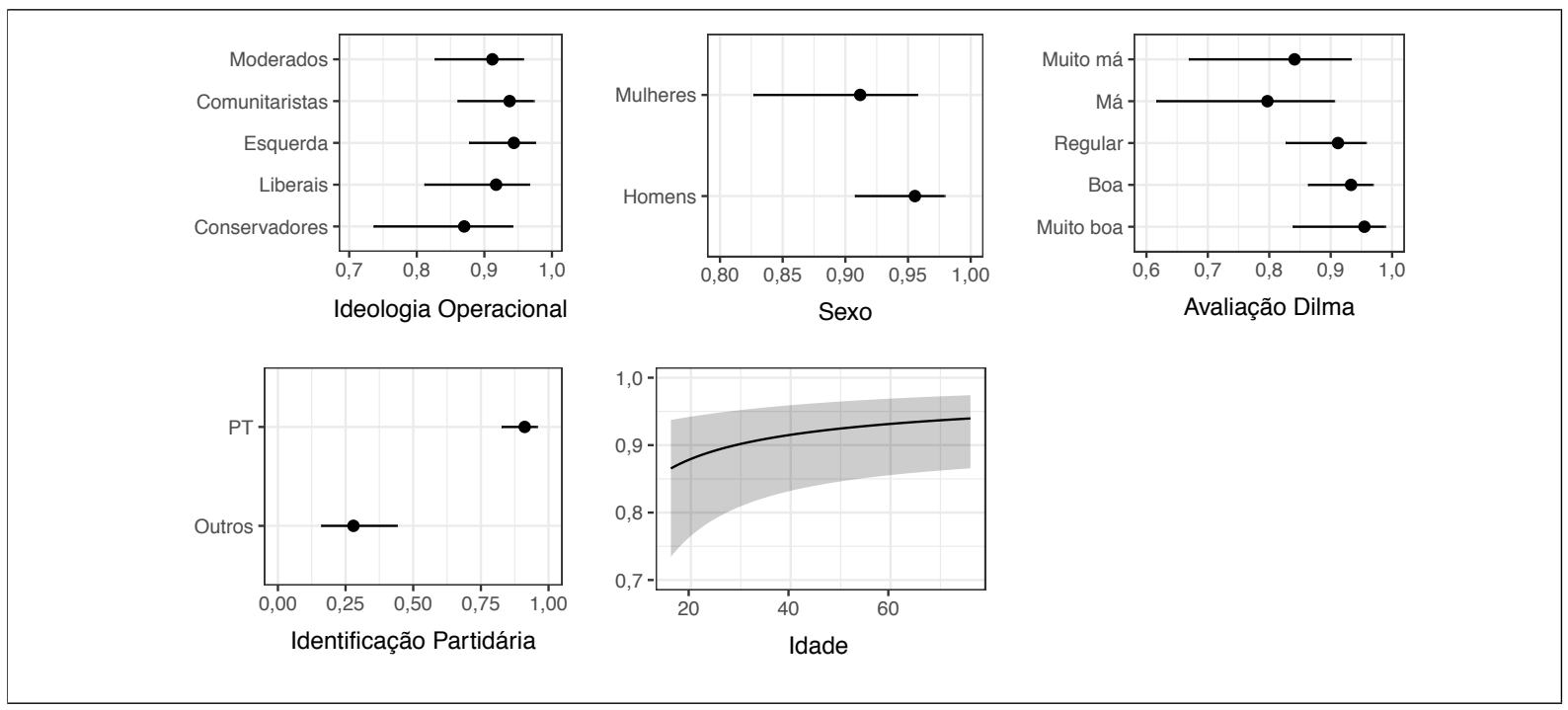

\subsection{Impressões acerca da literatura de comportamento político}

Em quase três décadas de estudo sobre os condicionantes do voto no país, os diagnósticos predominantes enfatizam um cenário sombrio: o caráter volátil e pouco estruturado das crenças políticas, pautado por compreensões intuitivas dos fundamentos do jogo institucional. Diante desse quadro, as análises mais positivas ressaltam a suposta independência de um eleitor não afeito à influência dos partidos e do sistema convencional de posicionamento no espectro esquerda-direita - horizonte propício, portanto, para uma avaliação aprimorada da atuação dos governantes. Em outras palavras, a "racionalidade" da conduta política dos eleitores estaria fincada apenas na avaliação do desempenho dos representantes. Assim, o votante típico do Brasil seria uma figura meramente reativa.

Fica a impressão, no entanto, que os postulados confeccionados nesse período tomaram, por óbvio, elaborações desenvolvidas a priori, ou seja, sem comprovações empíricas substantivas. A convicção de um conjunto de eleitores que padece de uma enfermidade, a "síndrome do Flamengo", sedimentou os alicerces de uma literatura menos atenta às composições de conviç̧ões políticas reais. A proposta, portanto, é de inclusão - tanto nos trabalhos acadêmicos, quanto nas pesquisas de opinião - dos princípios norteadores de formulações políticas atinentes às questões do universo coletivo.

Porquanto a universalização das democracias de baixa intensidade se consolida 
(Huntington, 1993), a agenda da ciência política brasileira deve se guiar pelos registros da qualidade das composições estatutárias, da ampliação dos espaços de participação e de tomada de decisão, da responsividade e da congruência das visões de mundo de representantes e de representados. Ademais, deve evitar comparações hierárquicas que sugerem a falta de "maturidade" dos eleitores das chamadas "jovens democracias", como se estes fossem o "museu vivo" de um futuro inexorável que tem na população dos países do norte global o ponto de chegada.

Ao longo do capítulo, portanto, foi demonstrado que mesmo os "jovens democratas" do Brasil se utilizam de questões de posição para escolher seus governantes. Além disso, o aspecto não é uma novidade construída com o passar dos anos, mas um elemento resiliente da política nacional desde a abertura do regime no final dos anos 1980. Cumpre informar a inclusão dos tradicionais preditores do voto em todos os modelos apresentados, fato que reforça os achados defendidos.

Se a estruturação das crenças fornece pistas para a explicação dos determinantes do sufrágio, a etapa seguinte descortinou o impacto dos sistemas ideológicos, convencionais e alternativos, na decisão eleitoral. Antes, todavia, testou-se um método latente para assegurar a validade das categorias ponderadas nas equações de regressão. A ACL preencheu o exame ao auxiliar no reconhecimento de cinco classes heterogêneas, a saber: a esquerda, os conservadores, os moderados, os liberais e os comunitaristas. A observação dos diferentes perfis sociodemográficos dos grupamentos acentua os traços singulares dessas categorias ideológicas. Por fim, mediante o uso de artifícios que evidenciam a vertente operacional da ideologia, expõe-se o peso significativo da variável em todos os anos observados. 



\title{
5. Considerações finais
}

\begin{abstract}
Não é de se admirar que não exista na plebe nenhuma verdade ou juízo, quando os principais assuntos de Estado são tratados nas suas costas e ela não faz conjecturas senão a partir das poucas coisas que não podem ser escondidas. Suspender o juízo é, com efeito, uma virtude rara. Querer, portanto, tratar de tudo nas costas dos cidadãos e que eles não façam sobre isso juízos errados e interpretem tudo mal é o cúmulo da estupidez. Com efeito, se a plebe pudesse moderar-se e suspender o juízo sobre as coisas que conhece mal, ou julgar corretamente a partir do pouco que conhece, seria sem dúvida mais digno ela governar em vez de ser governada.
\end{abstract}

- Bento de Espinosa, Tratado Político (1670).

Na ciência política, tal como no senso comum, muitas são as análises com visões pejorativas sobre capacidade dos cidadãos comuns em lidar com os assuntos públicos. Embora os níveis de embasamento empírico desses diagnósticos variem conforme as tradições acadêmicas dos diferentes países, elas certamente contribuíram para o rebaixamento do ideal democrático, sobretudo na segunda metade do século XX (Rennó, 2001; Miguel, 2003; Avritzer e Santos, 2003). Afinal, se os eleitores mantêm pouco interesse em relação à política institucional e/ou não conseguem compreender a suposta sofisticação das agendas coletivas contemporâneas, melhor que sejam representados por especialistas.

Joseph Schumpeter (2013), por exemplo, construiu seu edifício teórico ancorado nessa premissa. O fundador da concepção hegemônica de democracia considera que as vontades e opiniões dos indivíduos não passam de um "feixe indeterminado de impulsos vagos que volteiam em torno de palavras de ordem ou de impressões equivocadas (1984: 126)" - nada muito diferente da "Síndrome do Flamengo", exposta nos capítulos anteriores. Em outros termos, os cidadãos estão mais preocupados com seus afazeres privados e, por isso, não sabem tratar das questões coletivas. A causa desse desinteresse pode ser explicada pela presunção de uma natureza humana determinada, egoísta e afeita a ditames individuais.

O autor, então, defende uma formulação democrática procedimental, marcada pela competição entre elites e resumida ao ato de votar. Diante da irracionalidade das massas, 
cabe ao arranjo institucional restringir a participação popular e simular um mecanismo de mercado, no qual os candidatos competem pelas preferências dos eleitores, sem cederem espaço para as tomadas de decisão mais importantes. A alienação decisória na política é medida pelo voto, que funciona como moeda de troca na interação entre representados consumidores dos bens ofertados por partidos e postulantes a cargos públicos - e representantes - interessados em maximizar o sufrágio para garantir os postos de poder. Se a etimologia da palavra democracia remete ao governo do povo, com Schumpeter o conceito assumiu as feições de um método para se chegar a decisões políticas e administrativas.

Com efeito, a comprovação empírica dos postulados schumpeterianos pode ser facilmente encontrada em The People's Choice (1944), de Paul Lazarsfeld et al., publicada poucos anos antes de sua tese. No livro, o expoente austríaco da escola sociológica do voto, sublinhou a importância das características sociais na determinação das inclinações políticas e revelou a primeira evidência testada da ignorância política dos norte-americanos. Empregando um survey com margens limitadas, reduzida a um condado do estado de Ohio, Lazarsfeld constatou o desinteresse e a falta de informação dos objetos da pesquisa, que decidiam o voto seguindo padrões tradicionais ou motivados por aspectos afetivos. A influência dos meios de comunicação, foco do estudo, era ínfima, pois o sufrágio refletia condicionantes prévios, reverberando a desatenção e a ausência de preocupação dos inquiridos em avaliar as consequências de seus atos.

A "irracionalidade" não foi sempre o critério fundamental da incompetência, todavia. Em Olson (2003), a inaptidão tem o seu suposto justamente na racionalidade, já que os mesmos levam em conta um cálculo de custos e benefício na hora de conduzir suas ações. Como o impacto do voto sobre o resultado final do pleito costuma ser diminuto, o empenho em se manter atualizado e depositar o sufrágio nas urnas não compensa o esforço diante das possíveis recompensas. Logo, sob uma perspectiva alternativa, a inércia pode ser fruto de um balanço arrazoado. De uma maneira ou de outra, a carência de conhecimento apropriado é um dos pilares do estatuto da representação na teoria liberal.

Grosso modo, as teorias democráticas diferenciam-se justamente nesse ponto, pois não seria ilógico argumentar que o desânimo em relação à configuração política atual reside justamente no interdito de uma participação popular efetiva e na exclusão das pessoas das tomadas de decisão. Nesse sentido, Vitullo (2009) delimita três correntes contra- 
hegemônicas: 1) o participacionismo, representado pelos pensamentos de Macpherson, Pateman e Dahl - ligado a uma concepção abrangente de sociedade e não a um sistema político; 2) o deliberacionismo de Manin, Cohen e Bohman, que enfatiza a deliberação e o consenso; e 3) o republicanismo cívico, de Arendt e Barber, relacionado ao resgate de práticas democráticas e da vida cívica.

Fora os pressupostos desenvolvidos por autores com viés progressista, experimentos recentes reportam a vinculação de práticas de ampliação dos princípios formais e informais com o acréscimo da satisfação com o processo político - até quando os projetos produzem impactos exíguos de melhoria da vida cotidiana (Olken, 2010) - , o aumento dos níveis de informação e, consequentemente, de propriedade dos posicionamentos defendidos (Luskin, Fishkin e Jowell, 2002) e de congruência das predileções a respeito de temas coletivos entre a população e os governantes - especialmente em casos de desvios sistemáticos de interesses das partes (Leeman e Wasserfallen, 2016).

Mas e se os julgamentos de incapacidade vingaram graças a artefatos produzidos pelos próprios questionários survey? E se essas considerações foram sustentadas por preceitos a respeito de um modo ideal de pensar o jogo político?

Conforme exposto nos capítulos anteriores, durante muito tempo os politólogos se apoiaram numa prescrição pessimista e quase consensual acerca dessa incapacidade. Os achados que terminaram por sedimentar as incursões iniciais de Lazarsfeld basearam-se, sobretudo, no conceito de ideologia para avaliar os conhecimentos do eleitorado. Ao fim e ao cabo, o super issue, capaz de envolver as temáticas tangentes à política em um complexo estruturado, só fazia sentido para um pequeno segmento social, composto pelos mais sofisticados (Converse, 1964).

Por pontos, pode-se ressaltar o reducionismo desse tipo de raciocínio. De início, porque os questionários de opinião estão sujeitos a limitações de ordens variadas. Não convém aqui fazer um longo inventário desses problemas, aos argumentos defendidos neste trabalho basta afirmar que, quando submetidos a mensurações mais acuradas, o suposto desacerto das inclinações políticas não se revela tão evidente. Estudos recentes apresentam indicativos de constrição e estabilidade, para ficar nos parâmetros do próprio Converse (1964), das preferências dos indivíduos em regiões centrais ou periféricas do globo (Feldman e Johnston, 2014, Bakker e Greene, 2011, 2015; Bello, 2016). A opção metodológica 
seguida nesta análise, fundamentada em técnicas psicométricas, corrobora esses achados.

Sobre os conteúdos ideológicos, deve-se frisar a transitoriedade semântica dos vocábulos esquerda e direita durante os últimos três séculos. Assim, se as pesquisas acadêmicas se concentrarem apenas nos especialistas, em tempos atuais, os resultados não serão de todo uniformes. Da Revolução Francesa, passando pela consolidação do socialismo no século XIX, às guerras culturais decorrentes dos conflitos dos anos 1960, o que caracteriza a metáfora espacial, de fato, é a sua nem sempre evidente polissemia. A resiliência das categorias está assentada justamente em sua elasticidade, ou como na epígrafe da tese, no paradoxo presente no famoso raciocínio do romance O Leopardo, de Lampedusa (1963), segundo o qual as coisas têm que mudar para permanecerem iguais.

No Brasil, por exemplo, quando se posicionam, os cidadãos normalmente atribuem significados distintos ao contínuo, muitas vezes refletindo aspectos simbólico-afetivos - ou seja, relacionados a noções de pertencimento a determinados grupos sociais. Dentre os principais elementos valorativos, somente a afeição pela ordem foi capaz de separar as declarações de progressistas e conservadores. Os motivos da incompreensão, contudo, não supõem incapacidades individuais ou institucionais, mas de transformação da estrutura social.

Assim, não bastassem os obstáculos impostos pela transitoriedade semântica, a concepção de que os indivíduos organizam suas crenças de maneira monolítica não indica, ao menos para o autor destas linhas, uma hipótese exatamente sofisticada. A noção de multidimensionalidade, por conseguinte, ajusta-se melhor à forma com que os cidadãos ordenam suas preferências. Isto é, conquanto não tenham altos níveis de escolaridade, sejam especialistas ou membros da elite governante, estes pensam e se comportam de maneira ideológica. E a configuração de suas inclinações não se dá de modo inteiramente idiossincrático, mas observa certa coerência em domínios distintos - alimentando igualmente a confusão semântica.

Dito de outro modo, as pessoas mantêm um sistema estruturado de crenças políticas mesmo sem usarem, de forma direta ou consciente, os conceitos esquerda e direita (Feldman, 2013). Esses modelos ideológicos são melhor captados com análises latentes de temas cotidianos, cujo saliência facilita o entendimento dos cidadãos. Ao operacionalizar o construto referido como ideologia operacional, vimos que os entendimentos acerca 
da condução da política influenciam as decisões eleitorais e ocupam um espaço relevante junto a preditores de voto tradicionalmente enfatizados pela literatura, como a análise de desempenho e a simpatia/rejeição partidária.

Esta tese insere-se no catálogo de trabalhos acadêmicos nacionais e estrangeiros que têm revisitado a imperícia dos cidadãos e de suas escolhas políticas (Ansolabehere, et. al, 2008; Bakker e Greene, 2011, 2016; Bello, 2016). Em vista disso, pretendeu-se, ademais, animar uma reconfiguração do olhar dos especialistas a respeito das capacidades democráticas da população, relegada a atuações pontuais, em virtude, também, de um hipotético despreparo para a condução das atividades cívicas. Na medida em que o estudo não teve a intenção de esgotar as possibilidades de composições ideológicas possíveis no eleitorado brasileiro, mas de abrir passagem para investigações mais atentas aos condicionantes cognitivos dos indivíduos, a tarefa teórica fomenta incursões acadêmicas futuras, tanto na seara da psicologia política como nos exames de comportamento eleitoral.

O diagnóstico, portanto, não invalida asserções pautadas nas insuficiências dos sistemas democráticos em geral, e do brasileiro em particular, mas convida a uma reflexão crítica da normatividade com que os especialistas continuam construindo uma narrativa pejorativa a respeito das potencialidades do público. Em vez dos atestados de inépcia, mais significativos seriam os esforços voltados para a compreensão das considerações e dos comportamentos dos comuns.

Que estão para além de esquerda e direita. 


\section{Referências Bibliográficas}

\section{Referências}

[1] Abramowitz, A. I. (2010). The disappearing center: Engaged citizens, polarization, and American democracy. Yale University Press.

[2] Abramowitz, A. e Saunders, K. (1998). Ideological realignment in the us electorate. The Journal of Politics, 60(3):634-652.

[3] Almeida, A. (2001). A esquerda dos números à direita dos fatos. Insight Inteligencia, $15: 112-128$.

[4] Althusser, L. (1980). Ideologia e aparelhos ideológicos do Estado. Presença Lisboa.

[5] Alvarez, R. e Brehm, J. (1995). American ambivalence towards abortion policy: Development of a heteroskedastic probit model of competing values. American Journal of Political Science, pages 1055-1082.

[6] Amaral, O. e Ribeiro, P. F. (2015). Por que dilma de novo? uma análise exploratória do estudo eleitoral brasileiro de 2014. Revista de Sociologia e Política, 23(56):107-123.

[7] Ames, B. e Smith, A. (2010). Knowing left from right: ideological identification in brazil, 2002-2006. Journal of politics in latin america, 2(3):3-38.

[8] Ames, B. (2003). Os entraves da democracia no Brasil. FGV Editora.

[9] Amodio, D., Jost, J., and Master, S. e Yee, C. (2007). Neurocognitive correlates of liberalism and conservatism. Nature neuroscience, 10(10):1246-1247.

[10] Ansolabehere, S. and Rodden, J. e Snyder, J. (2008). The strength of issues: Using multiple measures to gauge preference stability, ideological constraint, and issue voting. American Political Science Review, 102(02):215-232.

[11] Ashton, M., Danso, H., Maio, G., Esses, V., and Bond, M. e Keung, D. (2005). Two dimensions of political attitudes and their individual difference correlates: A cross-cultural perspective. In Culture and social behavior: The Ontario symposium, volume 10, pages 1-29. Lawrence Erlbaum Mahwah, NJ. 
[12] Bafumi, J., Gelman, A., and Park, D. e Kaplan, N. (2005). Practical issues in implementing and understanding bayesian ideal point estimation. Political Analysis, pages $171-187$.

[13] Bafumi, Joseph e Herron, M. C. (2010). Leapfrog representation and extremism: A study of american voters and their members in congress. American Political Science Review, 104(03):519-542.

[14] Bafumi, J. e Shapiro, R. (2009). A new partisan voter. The Journal of Politics, 71(1):1-24.

[15] Bagozzi, R. e Edwards, E. (2000). Goal-striving and the implementation of goal intentions in the regulation of body weight. Psychology and Health, 15(2):255-270.

[16] Baker, A. e Greene, K. (2011). The latin american left's mandate: free-market policies and issue voting in new democracies. World Politics, 63(01):43-77.

[17] Baker, A. e Greene, K. (2015). Positional issue voting in latin america. The latin american voter: pursuing representation and accountability in challenging contexts, pages $173-94$.

[18] Baldassarri, D. e Gelman, A. (2008). Partisans without constraint: Political polarization and trends in american public opinion 1. American Journal of Sociology, 114(2):408-446.

[19] Baldassarri, D. e Goldberg, A. (2014). Neither ideologues nor agnostics: Alternative voters' belief system in an age of partisan politics. American Journal of Sociology, 120(1):45-95.

[20] Baldassarri, D. e Bearman, P. (2007). Dynamics of political polarization. American sociological review, 72(5):784-811.

[21] Baquero, M. e Castro, H. (1996). A erosão das bases democráticas: um estudo de cultura política. Condicionantes da consolidação democrática: ética, mídia e cultura política. Porto Alegre: UFRGS.

[22] Baquero, M. (1994). Os desafios na construção de uma cultura política democrática na américa latina: Estado e partidos políticos. Cultura política e democracia: Os desafios das sociedades contemporâneas, pages 26-41. 
[23] Bartle, J. and Dellepiane-Avellaneda, S. e Stimson, J. (2011). The moving centre: Preferences for government activity in britain, 1950-2005. British Journal of Political Science, 41(02):259-285.

[24] Bell, D. (1960). The end of ideology, volume 3. Free Press New York.

[25] Bello, A. (2016). A lógica social do voto correto no brasil. Opinião Pública, 22(2):466491.

[26] Benoit, K. e Laver, M. (2006). Party policy in modern democracies. Routledge.

[27] Biroli, F. e Miguel, L. F. (2015). Feminismo e política: uma introdução. Boitempo Editorial.

[28] Bishop, G. (2004). The illusion of public opinion: Fact and artifact in American public opinion polls. Rowman \& Littlefield Publishers.

[29] Bloom, P. and Arin, G. e Sommer, U. (2014). Globalization, threat and religious freedom. Political Studies, 62(2):273-291.

[30] Blyth, M. (2006). Great punctuations: prediction, randomness, and the evolution of comparative political science. American Political Science Review, 100(04):493-498.

[31] Boaz, D. e Kirby, D. (2006). The libertarian vote. Cato Institute Policy Analysis Series, 580 .

[32] Bobbio, N. (2001). Direita e Esquerda razões e significados de uma distinção política. Unesp.

[33] Bohn, S. (2004). Evangélicos no brasil: perfil socioeconômico, afinidades ideológicas e determinantes do comportamento eleitoral. Opinião Pública, 10(2):288-338.

[34] Bohn, S. (2011). Social policy and vote in brazil: Bolsa família and the shifts in lula's electoral base. Latin American Research Review, 46(1):54-79.

[35] Bonifácio, R. and Caselecchi, Gabriel e Freitas, V. (2014). Ideologia e voto nas eleicoes presidenciais brasileiras. In: O voto para presidente no Brasil: condicionantes e fatores explicativos (1989-2010). 
[36] Borsboom, D. (2005). Measuring the mind: Conceptual issues in contemporary psychometrics. Cambridge University Press.

[37] Bourdieu, P. (1982). A opinião pública não existe. Thiollent, Michel JM-Crítica metodológica e investigação social e enquête operária, São Paulo: Editora Polis.

[38] Brady, Henry E e Sniderman, P. M. (1985). Attitude attribution: A group basis for political reasoning. American Political Science Review, 79(04):1061-1078.

[39] Braga, M. S. e Pimentel, J. (2011). Os partidos políticos brasileiros realmente não importam? Opinião Pública, 17(2):271-303.

[40] Campbell, A. (1960). The american voter. University of Chicago Press.

[41] Carmines, E. G. and D'Amico, N. J. (2015). The new look in political ideology research. Annual Review of Political Science, 18:205-216.

[42] Carpini, Michael Delli e Keeter, S. (1997). What Americans know about politics and why it matters. Yale University Press.

[43] Carreirão, Y. e Barbetta, P. (2004). A eleição presidencial de 2002: a decisão do voto na região da grande são paulo. Revista Brasileira de Ciências Sociais, 19(56):75-93.

[44] Carreirão, Y. (2002). Identificação ideológica e voto para presidente. Opinião Pública, $8(1): 54-79$.

[45] Carreirão, Y. (2008). Opiniões políticas e sentimentos partidários dos eleitores brasileiros. Opinião pública, 14(2):319-351.

[46] Castro, M. e Santos, W. G. (1992). Sujeito e estrutura no comportamento eleitoral. Revista Brasileira de Ciencias Sociais.

[47] Clinton, J. and Jackman, Simon e Rivers, D. (2004). The statistical analysis of roll call data. American Political Science Review, 98(02):355-370.

[48] Conover, Pamela Johnston e Feldman, S. (1981). The origins and meaning of liberal/conservative self-identifications. American Journal of Political Science, pages $617-645$. 
[49] Converse, P. (1964). The Nature of Belief Systems in Mass Publics. London: Free Press of Glencoe.

[50] Dagnino, E. and Rivera, A. e Panfichi, A. (2006). La disputa por la construcción democrática en América Latina, volume 3. CIESAS.

[51] Della Porta, D. e Diani, M. (2009). Social movements: An introduction. John Wiley $\&$ Sons.

[52] Dixon, T., Maynard, J., Mildenberger, M., Milkoreit, M., Mock, S., Quilley, S., and Schröder, T. e Thagard, P. (2013). A complex systems approach to the study of ideology: Cognitive-affective structures and the dynamics of belief systems. Journal of social and political psychology, 1(1):337-363.

[53] Downs, A. (1957). An economic theory of political action in a democracy. Journal of Political Economy, 65(2):135-150.

[54] Ellis, Christopher e Stimson, J. A. (2012). Ideology in America. Cambridge University Press.

[55] Erikson, R. and MacKuen, M. e Stimson, J. (2002). The macro polity. Cambridge University Press.

[56] Evans, G. (1993). The decline of class divisions in britain? class and ideological preferences in the 1960s and the 1980s. British Journal of Sociology, pages 449-471.

[57] Evans, G., Heath, A., and Lalljee, M. (1996). Measuring left-right and libertarianauthoritarian values in the british electorate. British Journal of Sociology, pages 93-112.

[58] Feldman, S. e Johnston, C. (2014). Understanding the determinants of political ideology: Implications of structural complexity. Political Psychology, 35(3):337-358.

[59] Feldman, S. e Steenbergen, M. (2001). The humanitarian foundation of public support for social welfare. American Journal of Political Science, pages 658-677.

[60] Feldman, S. (1988). Structure and consistency in public opinion: The role of core beliefs and values. American Journal of political science, pages 416-440. 
[61] Feldman, S. (2013). Political ideology. In: Oxford Handbook of Political Psychology, $2 e d$.

[62] Feres, J. (2007). Evitando o debate público: os intelectuais universitários nos eua do pós-guerra. Estudos de Sociologia, 9(17).

[63] Feres, J. e Pogrebinschi, T. (2010). Teoria política contemporânea: uma introdução. Elsevier.

[64] Ferreira, D. and Batista, C. e Stabile, M. (2008). A evolução do sistema partidário brasileiro: número de partidos e votação no plano subnacional 1982-2006. Opinião Pública, 14(2):432-453.

[65] Figueiredo, M. (2008). A decisão do voto. Ed. Sumare.

[66] Fincher, C. L., Thornhill, R., and Murray, Damian R e Schaller, M. (2008). Pathogen prevalence predicts human cross-cultural variability in individualism/collectivism. Proceedings of the Royal Society of London B: Biological Sciences, 275(1640):1279-1285.

[67] Fiorina, M. and Abrams, S. e Pope, J. (2005). Culture war? Pearson Longman New York.

[68] Fraser, N. e Honneth, A. (2003). Redistribution or recognition?: a politicalphilosophical exchange. Verso.

[69] Freeden, M. (2001). Editorial: What is special about ideologies. Journal of Political Ideologies, 6(1):5-12.

[70] Freire, A. (2006). Bringing social identities back in: The social anchors of left-right orientation in western europe. International Political Science Review, 27(4):359-378.

[71] Freire, A. (2008). Party polarization and citizens' left-right orientations. Party Politics, 14(2):189-209.

[72] Freire, André e Kivistik, K. (2013). Mapping and explaining the use of the left-right divide. Brazilian Political Science Review, 7(3):61-89.

[73] Fuchs, Dieter e Klingemann, H.-D. (1990). The left-right schema. Continuities in political action: A longitudinal study of political orientations in three western democracies, pages 203-234. 
[74] Fukuyama, F. (1992). The End of History and the Last Man. New York: Avon Books.

[75] Furr, R Michael e Bacharach, V. R. (2013). Psychometrics: an introduction. Sage.

[76] Geertz, C. (1989). As interpretações das culturas. Rio de Janeiro: Guanabara.

[77] Gelman, Andrew e Hill, J. (2006). Data analysis using regression and multilevel/hierarchical models. Cambridge university press.

[78] Gerber, A. S., Huber, G. A., Doherty, D., and Dowling, Conor M e Ha, S. E. (2010). Personality and political attitudes: Relationships across issue domains and political contexts. American Political Science Review, 104(01):111-133.

[79] Geuss, R. (1981). The idea of a critical theory: Habermas and the Frankfurt School. Cambridge University Press.

[80] Gibson, E. (1992). Conservative electoral movements and democratic politics: core constituencies, coalition building, and the latin american electoral right. The Right and Democracy in Latin America, pages 13-42.

[81] Giddens, A. (1996). Para alem da esquerda e da direita o futuro da politica radical. Unesp São Paulo.

[82] Gill, J. e. G. (2002). Why does voting get so complicated? a review of theories for analyzing democratic participation. Statistical Science, 17(4):383-404.

[83] Goldfrank, B. (2011). Deepening local democracy in Latin America: Participation, decentralization, and the left. Penn State Press.

[84] Goren, P. (2004). Political sophistication and policy reasoning: A reconsideration. American Journal of Political Science, 48(3):462-478.

[85] Hare, C., Armstrong, D., Bakker, R., and Carroll, R. e Poole, K. (2015). Using bayesian aldrich-mckelvey scaling to study citizens' ideological preferences and perceptions. American Journal of Political Science, 59(3):759-774.

[86] Hartman, A. (2015). A war for the soul of America: A history of the culture wars. University of Chicago Press. 
[87] Hatemi, P. K., Hibbing, J. R., Medland, S. E., Keller, M. C., Alford, J. R., Smith, K. B., and Martin, Nicholas G e Eaves, L. J. (2010). Not by twins alone: Using the extended family design to investigate genetic influence on political beliefs. American Journal of Political Science, 54(3):798-814.

[88] Heath, A., Evans, G., and Martin, J. (1994). The measurement of core beliefs and values: The development of balanced socialist/laissez faire and libertarian/authoritarian scales. British Journal of Political Science, 24(01):115-132.

[89] Hirsch, J. B., DeYoung, C. G., and Xu, Xiaowen e Peterson, J. B. (2010). Compassionate liberals and polite conservatives: Associations of agreeableness with political ideology and values. Personality and Social Psychology Bulletin, 36:655-664.

[90] Houtman, D., Achterberg, P., and Derks, A. (2009). Farewell to the leftist working class. Transaction Publishers.

[91] Huckfeldt, R. e Sprague, J. (1995). Citizens, politics and social communication: Information and influence in an election campaign. Cambridge University Press.

[92] Hunt, L. (2007). Inventing human rights: A history. WW Norton \& Company.

[93] Hunter, W. e Power, T. (2007). Rewarding lula: executive power, social policy, and the brazilian elections of 2006. Latin American Politics and Society, 49(1):1-30.

[94] Huntington, S. (1993). The third wave: Democratization in the late twentieth century, volume 4. University of Oklahoma press.

[95] Hurwitz, J. e Peffley, M. (1987). How are foreign policy attitudes structured? a hierarchical model. American Political Science Review, 81(04):1099-1120.

[96] Inglehart, Ronald e Klingemann, H.-D. (1976). Party identification, ideological preference and the left-right dimension among western mass publics. Party identification and beyond: representations of voting and party competition, pages 243-273.

[97] Inglehart, R. (1984). The changing structure of political cleavages in western society. Electoral change in advanced industrial democracies: realignment or dealignment, pages 25-69. 
[98] Inglehart, R. (2007). Postmaterialist values and the shift from survival to selfexpression values.

[99] Jackman, S. (2000). Estimation and inference via bayesian simulation: An introduction to markov chain monte carlo. American Journal of Political Science, pages $375-404$.

[100] Jasmin, M. (2006). História dos conceitos e teoria política e social: referências preliminares. Revista Brasileira de Ciencias Sociais.

[101] Jost, J. (2006). The end of the end of ideology. American Psychologist, 61(7):651.

[102] Jost, J., Federico, C., and Napier, J. (2013). Political ideologies and their social psychological functions. The Oxford handbook of political ideologies, pages 232-250.

[103] Jost, J. and Nosek, B. e Gosling, S. (2008). Ideology: Its resurgence in social, personality, and political psychology. Perspectives on Psychological Science, 3(2):126136.

[104] Jost, J. T., Basevich, E., and Dickson, Eric S e Noorbaloochi, S. (2015). The place of values in a world of politics: Personality, motivation, and ideology. Handbook of Value: Perspectives from Economics, Neuroscience, Philosophy, Psychology and Sociology, page 351.

[105] Jost, J. T. and Federico, Christopher M e Napier, J. L. (2009). Political ideology: Its structure, functions, and elective affinities. Annual review of psychology, 60:307-337.

[106] Kaplan, D. (2008). Structural equation modeling: Foundations and extensions, volume 10. Sage Publications.

[107] Keck, M. (2010). Pt-a lógica da diferença: o partido dos trabalhadores na construção da democracia brasileira.

[108] Kerlinger, F. N. (1984). Liberalism and conservatism: The nature and structure of social attitudes, volume 1. Lawrence Erlbaum Assoc Incorporated.

[109] Key, V. O. (1966). The responsible electorate. Belknap Press of Harvard University Press. 
[110] Kinder, D. (1983). Diversity and complexity in american public opinion. Political science: The state of the discipline, pages 389-425.

[111] Kinder, D. R. (1998). Opinion and action in the realm of politics. McGraw-Hill.

[112] King, G. and Keohane, R. e Verba, S. (1994). Designing social inquiry: Scientific inference in qualitative research. Princeton university press.

[113] Kitschelt, H. (2000). Linkages between citizens and politicians in democratic polities. Comparative political studies, 33(6-7):845-879.

[114] Kitschelt, Herbert e Hellemans, S. (1990). The left-right semantics and the new politics cleavage. Comparative Political Studies, 23(2):210-238.

[115] Klingemann, H. (1979). Measuring ideological conceptualizations. Political action: Mass participation in five western democracies, pages 215-254.

[116] Knight, K. (2006). Transformations of the concept of ideology in the twentieth century. American Political Science Review, 100(04):619-626.

[117] Konder, L. (2002). A questão da ideologia. Editora Companhia das Letras.

[118] Koselleck, R. e Castelo-Branco, L. (1999). Crítica e crise: uma contribuição à patogênese do mundo burguês. Eduerj.

[119] Koselleck, R. (1989). Linguistic change and the history of events. The journal of Modern history, 61(4):650-666.

[120] Koselleck, R. (2004). Futures past: on the semantics of historical time. Columbia University Press.

[121] Kroh, M. (2007). Measuring left-right political orientation: The choice of response format. Public Opinion Quarterly, 71(2):204-220.

[122] Krosnick, J. A. and Visser, Penny S e Harder, J. (2010). The psychological underpinnings of political behavior. Handbook of social psychology.

[123] Kulin, J. e Seymer, A. (2014). What's driving the public? a cross-country analysis of political attitudes, human values and political articulation. Sociological Research Online, 19(1):14. 
[124] Laclau, E. (1986). Os novos movimentos sociais e a pluralidade do social. Revista Brasileira de Ciências Sociais, 1(2):41-47.

[125] Lane, R. E. (1962). Political ideology: why the American common man believes what he does. Free Press of Glencoe.

[126] Laponce, J. (1972). In search of the stable elements of the left-right landscape. Comparative Politics, 4(4):455-475.

[127] Lau, R. e Redlawsk, D. (2006). How voters decide: Information processing in election campaigns. Cambridge University Press.

[128] Lavareda, A. (2009). Emoções ocultas e estratégias eleitorais. Editora Objetiva.

[129] Layman, G. e Carsey, T. (2002). Party polarization and"conflict extension"in the american electorate. American Journal of Political Science, pages 786-802.

[130] Lazarsfeld, P. and Berelson, B. e Gaudet, H. (1968). The peoples choice: how the voter makes up his mind in a presidential campaign. New York Columbia University Press 1948.

[131] Leeman, L. e Wasserfallen, F. (2016). "the democratic effect of direct democracy.". American Political Science Review.

[132] Lelkes, Y. (2016). Mass polarization: Manifestations and measurements. Public Opinion Quarterly, 80(S1):392-410.

[133] Leopold, D. (2013). Marxism and ideology: From marx to althusser. The Oxford Handbook of Political Ideologies, page 20.

[134] Levendusky, M. S. and Pope, J. C. (2010). Measuring aggregate-level ideological heterogeneity. Legislative Studies Quarterly, 35(2):259-282.

[135] Levitin, T. E. and Miller, W. E. (1979). Ideological interpretations of presidential elections. American Political Science Review, 73(03):751-771.

[136] Lewis-Beck, M. (1985). Pocketbook voting in us national election studies: Fact or artifact? American Journal of Political Science, pages 348-356. 
[137] Licio, E. and Rennó, L. e Castro, H. (2009). Bolsa família e voto na eleição presidencial de 2006: em busca do elo perdido. Opinião Pública, 15(1):31-54.

[138] Limongi, F. e Cortez, R. (2010). As eleições de 2010 e o quadro partidário. Novos estudos-CEBRAP, (88):21-37.

[139] Lipset, S. (1960). Political man: The social basis of modern politics. New York: Doubleday.

[140] Luna, Juan Pablo e Kaltwasser, C. R. (2014). The Resilience of the Latin American Right. JHU Press.

[141] Lupia, A. (1994). Shortcuts versus encyclopedias: Information and voting behavior in california insurance reform elections. American Political Science Review, pages 6376.

[142] Lupia, A. e McCubbins, M. (2000). Elements of reason: Cognition, choice, and the bounds of rationality. Cambridge University Press.

[143] Luskin, R. and Fishkin, J. e Jowell, R. (2002). Considered opinions: Deliberative polling in britain. British Journal of Political Science, 32(03):455-487.

[144] MacRae, D. (1952). The relation between roll call votes and constituencies in the massachusetts house of representatives. American Political Science Review, 46(04):1046-1055.

[145] Manin, B. (1997). The principles of representative government. Cambridge University Press.

[146] Mannheim, K. and Willems, E. (1956). Ideologia e utopia: introdução à sociologia do conhecimento. Globo.

[147] Martin, A. D. and Quinn, K. M. (2002). Dynamic ideal point estimation via markov chain monte carlo for the us supreme court, 1953-1999. Political Analysis, pages 134153.

[148] Marx, K. e Engels, F. (2007). A ideologia alemã: crítica da mais recente filosofia alemã em seus representantes feuerbach, b. Bauer e Stirner, e do socialismo alemão em seus diferentes profetas (1845-1846). São Paulo: Boitempo. 
[149] McCutcheon, A. (1987). Latent class analysis. Number 64. Sage.

[150] Mendes, A. e Venturi, G. (2015). Eleição presidencial: o plano real na sucessão de itamar franco. Opinião Pública, 2(2):59-72.

[151] Meneguello, R. (2010). Alguns aspectos da lógica de coalizões partidárias. cidadãos e política: diagnóstico da adesão democrática, comportamento e valores.

[152] Miguel, L. F. (2000). Representação política em 3-d: elementos para uma teoria ampliada da representação política. Revista Brasileira de Ciencias Sociais.

[153] Mill, J. (1832). Use and abuse of political terms. Collected works of JS Mill, 18.

[154] Nicolau, J. (2006). O sistema eleitoral de lista aberta no brasil. Dados, 49(4):689720.

[155] Nicolau, J. (2007a). An analysis of the 2002 presidential elections using logistic regression. Brazilian Political Science Review, 1(1):125-135.

[156] Nicolau, J. e Peixoto, V. (2007b). As bases municipais da votação de lula em 2006. Cadernos do Fórum Nacional, 6:15-25.

[157] Nie, N. and Verba, S e John, R. (1976). Petrocik. The Changing American Voter.

[158] Nylund, K. and Asparouhov, T. e Muthén, B. (2007). Deciding on the number of classes in latent class analysis and growth mixture modeling: A monte carlo simulation study. Structural equation modeling, 14(4):535-569.

[159] Oliveira, C. e Turgeon, M. (2015). Ideologia e comportamento político no eleitorado brasileiro. Opinião Pública, 21(3):574-600.

[160] Olken, B. (2010). Direct democracy and local public goods: Evidence from a field experiment in indonesia. American political science review, 104(02):243-267.

[161] Olson, M. (2009). The logic of collective action, volume 124. Harvard University Press.

[162] Oro, A. (2006). A política da Igreja Universal e seus reflexos nos campos religioso e político brasileiros. Revista Brasileira de Ciencias Sociais. 
[163] Osburn, H. G. (2000). Coefficient alpha and related internal consistency reliability coefficients. Psychological methods, 5(3):343.

[164] Oxley, D. R., Smith, K. B., Alford, J. R., Hibbing, M. V., Miller, J. L., Scalora, M., and Hatemi, Peter K e Hibbing, J. R. (2008). Political attitudes vary with physiological traits. science, 321(5896):1667-1670.

[165] Page, B., Shapiro, R., and Gronke, P. e Rosenberg, R. (1984). Constituency, party, and representation in congress. Public Opinion Quarterly, 48(4):741-756.

[166] Peixoto, V. e Rennó, L. (2011). Mobilidade social ascendente e voto: as eleições presidenciais de 2010 no brasil. Opinião Pública, 17(2):304-332.

[167] Peres, P. and Ricci, P. e Rennó, L. (2011). A variação da volatilidade eleitoral no brasil: um teste das explicações políticas, econômicas e sociais. Latin American Research Review, 46(3):46-68.

[168] Peres, P. S. (2008). Comportamento ou instituições? a evolução histórica do neoinstitucionalismo da ciência política. Revista Brasileira de Ciências Sociais.

[169] Peress, M. (2009). Small chamber ideal point estimation. Political Analysis, pages 276-290.

[170] Pimentel, J. (2010). Razão e emoção: o voto na eleição presidencial de 2006. Opinião Pública, 16(2):516-541.

[171] Piurko, Y. and Schwartz, S. H e Davidov, E. (2011). Basic personal values and the meaning of left-right political orientations in 20 countries. Political Psychology, $32(4): 537-561$.

[172] Poole, K. e Rosenthal, H. (1985). A spatial model for legislative roll call analysis. American Journal of Political Science, pages 357-384.

[173] Poole, K. T. (2005). The evolving influence of psychometrics in political science. In: The Oxford Handbook of Political Methodology.

[174] Popp, E. e Rudolph, T. (2011). A tale of two ideologies: Explaining public support for economic interventions. The Journal of Politics, 73(3):808-820. 
[175] Rancière, J. (2014). Hatred of democracy. Verso Books.

[176] Rawls, J. (2005). A theory of justice. Harvard university press.

[177] Reis, F. W. (1988). Identidade, política e a teoria da escolha racional. Revista Brasileira de Ciências Sociais, 3(6):26-38.

[178] Reise, S. and Waller, N. e Comrey, A. (2000). Factor analysis and scale revision. Psychological assessment, 12(3):287.

[179] Rennó, L. e Cabello, A. (2010). As bases do lulismo a volta do personalismo, realinhamento ideológico ou não alinhamento? Revista Brasileira de Ciências Sociais, $25(74)$.

[180] Rennó, L. e Ames, B. (2014). Pt no purgatório: ambivalência eleitoral no primeiro turno das eleições presidenciais de 2010. Opinião Pública, 20(1):01-25.

[181] Rennó, L. (2001). Confiança interpessoal e comportamento político: microfundamentos da teoria do capital social na américa latina. Opinião pública, 7(1):33-59.

[182] Ribeiro, P. (2013). Organização e poder nos partidos brasileiros: uma análise dos estatutos. Revista Brasileira de Ciência Política, 10:225.

[183] Rodrigues, L. M. (1987). Quem é quem na Constituinte: uma análise sócio-política dos partidos e deputados. OESP.

[184] Rodrigues, G. e Fuks, M. (2015). Social groups and political preference: the evangelical vote in brazil. Revista Brasileira de Ciências Sociais, 30(87):115-128.

[185] Samuels, D. e Zucco, C. (2014). The power of partisanship in brazil: Evidence from survey experiments. American Journal of Political Science, 58(1):212-225.

[186] Samuels, D. (1997). Determinantes do voto partidário em sistemas eleitorais centrados no candidato: evidências sobre o brasil. Dados, 40(3).

[187] Samuels, D. (2004). From socialism to social democracy: Party organization and the transformation of the workers' party in brazil. Comparative Political Studies, 37(9):9991024 . 
[188] Sani, G. e Sartori, G. (1983). Polarization, fragmentation and competition in western democracies. Western European party systems, pages 307-340.

[189] Sartori, G. (1979). Politics, ideology, and belief systems. American Political Science Review, 63(02):398-411.

[190] Schreiber, D., Fonzo, G., Simmons, A. N., Dawes, C. T., Flagan, T., and Fowler, James H e Paulus, M. P. (2013). Red brain, blue brain: Evaluative processes differ in democrats and republicans. PLoS One, 8(2).

[191] Schumpeter, J. (2013). Capitalism, socialism and democracy. Routledge.

[192] Schwartz, S. and Vittorio, G. e Vecchione, M. (2010). Basic personal values, core political values, and voting: A longitudinal analysis. Political Psychology, 31(3):421452.

[193] Segrillo, A. (2004). A confusão esquerda/direita no mundo pós-muro de Berlin: uma análise e uma hipótese. SciELO Brasil.

[194] Sell, C. E. (2006). Introdução à sociologia: política e sociedade na modernidade tardia. Vozes.

[195] Settle, J. E., Dawes, C. T., and Christakis, Nicholas A e Fowler, J. H. (2010). Friendships moderate an association between a dopamine gene variant and political ideology. The Journal of Politics, 72(4):1189-1198.

[196] Shapiro, R. (2011). Public opinion and american democracy. Public Opinion Quarterly, 75(5):982-1017.

[197] Sibley, Chris G e Duckitt, J. (2008). Personality and prejudice: A meta-analysis and theoretical review. Personality and Social Psychology Review, 12(3):248-279.

[198] Silva, Thiago Moreira e Rennó, L. (2015). Perdendo o fio da meada: contradicoes e ambiguidades na teoria do realinhamento. Revista Brasileira de Informacao Bibliográfica, 77:5-23.

[199] Silveira, F. E. (1998). A decisão do voto no Brasil. Edipucrs. 
[200] Singer, A. (1999). Esquerda e direita no eleitorado brasileiro: a identificação ideológica nas disputas presidenciais de 1989 e 1994. Edusp.

[201] Singer, A. (2012). Os sentidos do lulismo: reforma gradual e pacto conservador. Editora Companhia das Letras.

[202] Smith, K. B., Oxley, D., Hibbing, M. V., and Alford, John R e Hibbing, J. R. (2011). Disgust sensitivity and the neurophysiology of left-right political orientations. PloS one, 6(10).

[203] Sniderman, P. e Stiglitz, E. (2012). The reputational premium: A theory of party identification and policy reasoning. Princeton University Press.

[204] Sniderman, P. and Tetlock, P. e Elms, L. (2001). Public opinion and democratic politics: The problem of non-attitudes and the social construction of political judgment. Citizens and politics: Perspectives from political psychology, pages 254-88.

[205] Sniderman, P. M. and Brody, Richard A e Tetlock, P. E. (1991). The role of heuristics in political reasoning: A theory sketch. Reasoning and Choice: Explorations in Political Psychology.

[206] Soares, F., Soares, S., and M, Marcelo e Osório, R. (2006). Programas de transferência de renda no brasil: impactos sobre a desigualdade.

[207] Soares, G. e Terron, S. (2008). Dois lulas: a geografia eleitoral da reeleição (explorando conceitos, métodos e técnicas de análise geoespacial). Opinião Pública, 14(2):269301.

[208] Spinoza, B. (1988). Tratado teológico-político. Imprensa Nacional-Casa da Moeda.

[209] Stimson, J. A. (2004). Tides of consent: How opinion movements shape American politics. Cambridge University Press.

[210] Stokes, D. (1963). Spatial models of party competition. American political science review, 57(02):368-377.

[211] Stråth, B. (2013). Ideology and conceptual history. The Oxford Handbook of Political Ideologies, page 1 . 
[212] Swedlow, B. (2008). Beyond liberal and conservative: Two-dimensional conceptions of ideology and the structure of political attitudes and values. Journal of Political Ideologies, 13(2):157-180.

[213] Tarouco, G. e Madeira, R. (2013). Partidos, programas e o debate sobre esquerda e direita no brasil. Revista de Sociologia e Política, 21(45):149.

[214] Tavares, J. (1994). Sistemas eleitorais nas democracias contemporâneas: teoria, instituições, estratégia. Relume Dumará.

[215] Telles, H. (2016). A direita vai às ruas: o antipetismo, a corrupção e democracia nos protesto antigoverno. Ponto-e-Vírgula. Revista de Ciências Sociais. ISSN 1982-4807, (19).

[Telles] Telles, H. e Storni, T. Ideologias, atitudes e decisão de voto em eleitores de direita e de esquerda1. Revista latinoamericana de opinión pública: investigación social aplicada (año 2011), page 87.

[217] Thagard, P. (2006). Evaluating explanations in law, science, and everyday life. Current Directions in Psychological Science, 15(3):141-145.

[218] Treier, Shawn e Hillygus, D. S. (2009). The nature of political ideology in the contemporary electorate. Public Opinion Quarterly, page nfp067.

[219] Treier, Shawn e Jackman, S. (2008). Democracy as a latent variable. American Journal of Political Science, 52(1):201-217.

[220] Tybur, J. M., Merriman, L. A., Hooper, A. E. C., and McDonald, Melissa M e Navarrete, C. D. (2010). Extending the behavioral immune system to political psychology: Are political conservatism and disgust sensitivity really related? Evolutionary Psycho$\log y, 8(4)$.

[221] Van Dyck, B. e Montero, A. (2015). Eroding the clientelist monopoly: The subnational left turn and conservative rule in northeastern brazil. Latin American Research Review, 50(4):116-138.

[222] Verba, S. and Schlozman, Kay Lehman e Brady, H. E. (1995). Voice and equality: Civic voluntarism in American politics. Harvard University Press. 
[223] Vitullo, G. (2009). Representação política e democracia representativa são expressões inseparáveis? elementos para uma teoria democrática pós-representativa e pósliberal. Revista Brasileira de Ciência Política, 2:271.

[224] Von Mettenheim, K. (1995). The Brazilian voter: mass politics in democratic transition, 1974-1986. University of Pittsburgh Pre.

[225] Wiesehomeier, N. e Doyle, D. (2012). Attitudes, ideological associations and the left-right divide in latin america. Journal of Politics in Latin America, pages 3-33.

[226] Zaller, J. (1992). The nature and origins of mass opinion. Cambridge university press.

[227] Zamboni, G., Gozzi, M., Krueger, F., Duhamel, J.-R., and Sirigu, Angela e Grafman, J. (2009). Individualism, conservatism, and radicalism as criteria for processing political beliefs: a parametric fmri study. Social Neuroscience, 4(5):367-383.

[228] Zechmeister, Elizabeth e Corral, M. (2010). The varying economic meaning of'left 'and'right 'in latin america. AmericasBarometer Insights Series, 38:1-10.

[229] Zschirnt, S. (2011). The origins and meaning of liberal/conservative selfidentifications revisited. Political Behavior, 33(4):685-701.

[230] Zucco, C. e Power, T. (2013). Bolsa família and the shift in lula's electoral base, 2002-2006: A reply to bohn. Latin American Research Review, 48(2):3-24.

[231] Zucco Jr, C. (2011). Esquerda, direita e governo: A ideologia dos partidos politicos brasileiros. In: O Congresso por ele mesmo: autopercepcoes da classe política brasileira.

[232] Zumbrunnen, John e Gangl, A. (2008). Conflict, fusion, or coexistence? the complexity of contemporary american conservatism. Political Behavior, 30(2):199-221.

\section{Apêndice}

\section{Capítulo 2: operacionalização das variáveis}


$\mathrm{Na}$ escala de posicionamento ideológico, foram usadas perguntas que tipicamente pedem para o respondente se colocar em um dos pólos situado entre esquerda e direita. Para as escalas de 7 pontos (pesquisas da série "Cultura Política"), os valores 1, 2 e 3 foram atribuídos à esquerda; 4 ao centro e 5, 6 e 7 à direita. Nas escalas de 10 pontos (Lapop e ESEB), codifiquei a esquerda com os pontos 1, 2 e 3; 4, 5, 6 e 7 como centro; e 8, 9 e 10 como direita. Por último, nas escalas de 11 pontos (Latino Barômetro), 0 a 3 como esquerda; 4 a 6 como centro e 7 a 10 como direita.

\section{Figura 3: percepções de PT e PSDB quanto ao posicionamento ideológico.}

"Na política as pessoas falam muito de direita e esquerda. Gostaria que o(a) Sr(a) usasse um número de zero a 10 para dizer se o partido político que eu vou dizer é de direita ou de esquerda. Zero significa que o partido é de direita e 10 que é de esquerda. Quando eu falar o nome de um partido que o(a) Sr(a) não conhece, apenas diga que não o conhece".

\section{Perguntas utilizadas no modelo da tabela 9:}

\section{Valores}

Igualdade de salários: "Incomes should be made more equal"vs. "We need larger income differences as incentives for individual effort".

Responsabilidade do Estado: "Private ownership of business and industry should be increased"vs. "Government ownership of business and industry should be increased".

Competição: "Competition is good. It stimulates people to work hard and develop new ideas"vs. "Competition is harmful. It brings out the worst in people".

Aborto: "Please tell me for each of the following actions whether you think it can always be justified, never be justified, or something in between: Abortion".

Homossexualidade: "Please tell me for each of the following actions whether you think it can always be justified, never be justified, or something in between: Homosexuality".

Divórcio: "Please tell me for each of the following actions whether you think it can always be justified, never be justified, or something in between: Divorce".

Sexo antes do casamento: "Please tell me for each of the following actions whether you think it can always be justified, never be justified, or something in between: Sex before 
marriage".

Greves: "Now I'd like you to look at this card. I'm going to read out some forms of political action that people can take, and I'd like you to tell me, for each one, whether you have done any of these things, whether you might do it or would never under any circumstances do it: Joining strikes".

Boicotes: "Now I'd like you to look at this card. I'm going to read out some forms of political action that people can take, and I'd like you to tell me, for each one, whether you have done any of these things, whether you might do it or would never under any circumstances do it: "Joining in boycotts".

Manifestações pacíficas: "Now I'd like you to look at this card. I'm going to read out some forms of political action that people can take, and I'd like you to tell me, for each one, whether you have done any of these things, whether you might do it or would never under any circumstances do it: "Attending peacefull manifestations".

Protestos: "Now I'd like you to look at this card. I'm going to read out some forms of political action that people can take, and I'd like you to tell me, for each one, whether you have done any of these things, whether you might do it or would never under any circumstances do it: Any other act of protest".

\section{Símbolos de esquerda}

"I am going to name a number of organisations. For each one, could you tell me how much confidence you have in them: is it a great deal of confidence, quite a lot of confidence, not very much confidence or none at all? Labour unions"

"I am going to name a number of organisations. For each one, could you tell me how much confidence you have in them: is it a great deal of confidence, quite a lot of confidence, not very much confidence or none at all? Human Rights Movement".

"I am going to name a number of organisations. For each one, could you tell me how much confidence you have in them: is it a great deal of confidence, quite a lot of confidence, not very much confidence or none at all? Women's Movement."

\section{Símbolos de direita}


"I am going to name a number of organisations. For each one, could you tell me how much confidence you have in them: is it a great deal of confidence, quite a lot of confidence, not very much confidence or none at all? Armed Forces".

"I am going to name a number of organisations. For each one, could you tell me how much confidence you have in them: is it a great deal of confidence, quite a lot of confidence, not very much confidence or none at all? The Police".

"I am going to name a number of organisations. For each one, could you tell me how much confidence you have in them: is it a great deal of confidence, quite a lot of confidence, not very much confidence or none at all? The Major Companies".

\section{Capítulo 4: operacionalização das variáveis}

\section{Tabela 16}

\section{Cultura Política 1993}

Dimensão econômica

"Agora, vou ler frases e gostaria de saber a sua opinião sobre elas. O Brasil estaria bem melhor se nós nos preocupássemos menos com que todo mundo seja igual".

"Agora, vou ler frases e gostaria de saber a sua opinião sobre elas. As leis e os impostos do governo impedem as empresas de ter os lucros que necessitam".

"Agora, vou ler frases e gostaria de saber a sua opinião sobre elas. É preciso dar mais liberdade para as empresas dispensarem os seus empregados".

"Agora, vou ler frases e gostaria de saber a sua opinião sobre elas. O governo deveria oferecer menos serviços públicos, incluindo coisas como saúde e educação, para reduzir os impostos".

Dimensão social

"Agora, eu gostaria que você me dissesse se está de acordo, ou em desacordo com as seguintes afirmações: O melhor que uma mulher pode fazer é ocupar-se de sua casa".

"Agora, eu gostaria que você me dissesse se está de acordo, ou em desacordo com as 
seguintes afirmações: Os homossexuais são pessoas que devem ser aceitos como qualquer outra".

"Agora, eu gostaria que você me dissesse se está de acordo, ou em desacordo com as seguintes afirmações: Deve-se permitir o aborto a toda mulher que queira fazê-lo".

\section{Ordem}

"Agora, eu gostaria de saber o que você acha de certas coisas que, às vezes, o governo faz quando há protestos: Usar a polícia contra manifestações de rua".

"Agora, eu gostaria de saber o que você acha de certas coisas que, às vezes, o governo faz quando há protestos: Fazer leis para proibir manifestações de protesto".

"Agora, eu gostaria de saber o que você acha de certas coisas que, às vezes, o governo faz quando há protestos: Usar tropas para acabar com greves".

"Você concorda ou discorda que o governo brasileiro deva ter o direito de: Proibir greves". Avaliação retrospectiva egotrópica

"Comparando com a vida que os seus pais tiveram quando tinham a sua idade, você acha que do ponto de vista financeiro você está:. Melhor, igual, pior ou não sabe?"

Identificação partidária

"Agora, eu gostaria de fazer algumas perguntas sobre os partidos políticos brasileiros: Primeiro, poderia me dizer de que partido político você se sente habitualmente mais próximo?".

Avaliação do candidato

"Agora, gostaria de saber como você vê algumas figuras destacadas da vida do Brasil e do mundo. Você simpatiza ou não simpatiza com: Lula".

Sofisticação (variável aditiva)

"Você poderia me dizer o nome de alguns políticos do país, do seu estado e de sua cidade? Presidente da República".

"Você poderia me dizer o nome de alguns políticos do país, do seu estado e de sua cidade? 
Governador do Estado".

"Você poderia me dizer o nome de alguns políticos do país, do seu estado e de sua cidade? Um senador do seu estado".

"Você poderia me dizer o nome de alguns políticos do país, do seu estado e de sua cidade? Um deputado do seu estado".

"Você poderia me dizer o nome de alguns políticos do país, do seu estado e de sua cidade? Um presidente de partido político".

\section{Eseb 2002}

Dimensão econômica

"O governo deve controlar o preço de todos os serviços básicos, como por exemplo do transporte".

"O governo deve definir qual o valor dos salários de todos os funcionários de todas as empresas do Brasil".

"O governo deve controlar os preços de todos os produtos vendidos no Brasil".

Dimensão social

"Vou ler outras frases e para cada frase eu gostaria que o(a) $\operatorname{Sr}(a)$ dissesse se concorda muito, concorda um pouco, discorda um pouco ou discorda muito. Um programa de televisão que defende o casamento de homem com homem e mulher com mulher deve ser proibido".

"Na sua opinião: Os homens devem dividir com as mulheres o trabalho de cuidar da casa e dos filhos ou essa é uma responsabilidade da mulher?"

"Com qual das frases o(a) Sr(a) concorda mais: O aborto deve ser proibido em qualquer situação, o aborto deve ser permitido se a mulher ficar grávida por causa de estupro ou o aborto deve ser permitido em qualquer situação?"

Ordem

"Agora eu vou mencionar vários tipos de protestos contra o governo, e gostaria que o(a) 
$\operatorname{Sr}(\mathrm{a})$ dissesse se o protesto deve sempre ser permitido, deve ser permitido na maioria das vezes, deve ser proibido na maioria das vezes, ou se deve sempre ser proibido.

Passeatas.

Greves.

Comícios".

Avaliação do candidato

"Agora usando as mesmas notas, gostaria que o(a) $\operatorname{Sr}(a)$ me dissesse o quanto gosta de alguns políticos que vou mencionar. Quero lembrar que, zero significa que o(a) Sr(a) NÃO gosta do político que vou mencionar e dez que o(a) Sr(a) gosta muito. De novo, se o(a) Sr(a) não conhecer o político que eu disser, diga apenas que não o conhece.

Lula.

José Serra".

Identificação partidária

"Qual o partido que melhor representa a maneira como o(a) $\operatorname{Sr}(a)$ pensa?"

Avaliação economia

"O(a) $\mathrm{Sr}($ a) está preocupado em perder o emprego/trabalho nos próximos 6 meses?"

Avaliação de governo

"Na sua opinião, de uma maneira geral o Governo Fernando Henrique nos últimos 4 anos foi: ótimo, bom, regular, ruim ou péssimo".

Sofisticação (variável aditiva)

"Na sua opinião, qual é o partido do Presidente Fernando Henrique Cardoso?"

"Na sua opinião o número 13 é de qual partido?"

"Nessa eleição, Denise Frossard foi eleita Deputada Estadual, Deputada Federal ou Senadora?" 
"E Carlos Minc, foi eleito Deputado Estadual, Deputado Federal ou Senador?"

\section{LAPOP 2006}

Dimensão econômica

"É preciso dar mais liberdade para as empresas dispensarem os empregados".

"O governo deveria oferecer menos serviços públicos, como saúde e educação, para reduzir os impostos".

"Quanto menos o governo intervier na economia, melhor para o país".

"Se o país for rico, não importa que haja muitas desigualdades econômicas e sociais".

Dimensão social

"No geral, homens são mais adequados para a carreira política do que mulheres".

"Quando o desemprego é elevado, os homens deveriam ter mais direito ao trabalho do que as mulheres".

"Agora eu vou falar de assunto polêmico. O que o(a) sr(a) acha de homens que fazem sexo com homens?"

Ordem

"Agora vamos mudar para outro cartão. Este novo cartão tem uma escala de 10 pontos, que vão de 1 a 10, sendo que o 1 indica que o sr./sra desaprova fortemente e o 10 indica que aprova fortemente. Vou ler uma lista de algumas ações ou coisas que as pessoas podem fazer para atingir suas metas e objetivos políticos. Quero que me diga aprovaria ou desaprovaria as seguintes ações:

"A participação de pessoas no bloqueio de ruas ou rodovias".

"A participação de pessoas em manifestações permitidas por lei".

"A ocupação de fábricas, escritórios ou outros edifícios".

Sofisticação (variável aditiva)

"Qual é o nome do atual presidente dos Estados Unidos?" 
"Como se chama o Presidente da Câmara de Deputados?

"De quanto tempo é o mandato do presidente no Brasil?"

"Como se chama o presidente do Chile?"

"Qual é o partido do presidente Lula?"

Avaliação prospectiva

"O(a) Sr(a) está preocupado em perder o emprego/trabalho nos próximos 6 meses?"

Avaliação de governo

"E falando do governo, em geral, como o sr./sra. avalia o trabalho que o Presidente Lula está realizando?"

Avaliação econômica sociotrópica

"Como sr/sra. avalia, em geral, sua situação econômica? O sr/sra acha que é muito boa, boa, nem boa nem má, má ou muito má?"

Avaliação econômica egotrópica

"Como sr/sra. avalia, em geral, sua situação econômica? O sr/sra acha que é muito boa, boa, nem boa nem má, má ou muito má?"

Identificação partidária

"Qual o partido que melhor representa a maneira como o(a) $\operatorname{Sr}($ a) pensa?"

Bolsa familia

"O(A) sr./sra. ou alguém em sua casa recebe ajuda mensal em dinheiro ou em produtos do governo, como por exemplo do Programa Bolsa Família?"

\section{Lapop 2010}

Avaliação economia (sociotrópica)

"Agora, falando da economia...Como o(a) sr./sra. avalia a situação econômica do país? $\mathrm{O}(\mathrm{A})$ sr./sra. acha que é muito boa, boa, nem boa nem má, má ou muito má?" 
Avaliação retrospectiva (sociotrópica)

"O (a) sr./sra. considera que a situação econômica atual do país está melhor, igual, ou pior que há doze meses?"

Avaliação prospectiva (sociotrópica)

"O(A) sr./sra. diria que em doze meses a situação econômica do país vai ficar melhor, igual ou pior do que está agora?

Avaliação economia (egotrópica)

"Como o(a) sr./sra. avalia, em geral, sua situação econômica? O(A) sr./sra. acha que é muito boa, boa, nem boa nem má, má ou muito má?"

Avaliação retrospectiva (egotrópica)

"O(A) sr./sra. acha que sua atual situação econômica está melhor, igual ou pior que há doze meses?"

Avaliação prospectiva (egotrópica)

"O(A) sr./sra. diria que em doze meses sua situação econômica vai ficar melhor, igual ou pior do que está agora?"

Avaliação de governo

"Falando em geral do atual governo, como o(a) sr./sra. avalia o trabalho que o Presidente Lula está realizando".

Dimensão econômica

"O Estado brasileiro, mais que os indivíduos, deve ser o responsável principal pela garantia do bem-estar das pessoas. Até que ponto concorda ou discorda desta frase?"

"O Estado brasileiro, mais do que as empresas privadas, deve ser o responsável principal por criar empregos. Até que ponto concorda ou discorda desta frase?"

"O Estado brasileiro, mais do que o setor privado, deve ser o responsável pelo pagamento das aposentadorias. Até que ponto concorda ou discorda desta frase?" 
"O Estado brasileiro, mais do que o setor privado, deve ser o responsável pelo provimento de serviços de saúde (hospitais). Até que ponto concorda ou discorda desta frase?"

Dimensão social

"E agora, mudando de assunto e pensando nos homossexuais, quanto o(a) sr./sra. aprova ou desaprova que estas pessoas possam candidatar-se para cargos públicos?"

"Quanto o(a) sr./sra. aprova ou desaprova que casais homossexuais tenham o direito de se casar?"

"A mistura das raças é bom para o Brasil. Até que ponto o(a) sr./sra. concorda ou discorda desta frase?"

"Estaria de acordo que uma filha ou filho seu se casasse com uma pessoa negra. Até que ponto o(a) sr./sra. concorda ou discorda desta frase?"

Ordem

"A participação de pessoas em manifestações permitidas por lei. Até que ponto aprova ou desaprova?"

"A participação de pessoas em uma organização ou grupo para resolver os problemas das comunidades. Até que ponto aprova ou desaprova?"

"A invasão de propriedades ou terrenos privados para protestar. Até que ponto aprova ou desaprova?"

Bolsa família

"O(A) sr./sra. ou alguém em sua casa recebe ajuda mensal em dinheiro ou em produtos do governo, como por exemplo do Programa Bolsa Família?"

"Atualmente o(a) sr./sra. simpatiza com algum partido político?"

\section{ESEB 2014}

Dimensão econômica

"O governo precisa se responsabilizar mais para garantir o sustento de todos". 
"Deveria haver mais iniciativa privada na indústria e no comércio".

"A renda deve ser distribuída de forma mais igualitária".

Avaliação de governo

"Na sua opinião, de uma maneira geral o governo da presidente Dilma Rousseff nos últimos 4 anos foi ótimo, bom, ruim ou péssimo?"

Avaliação prospectiva (egotrópica)

"Pensando no futuro, daqui uns 10 anos, o(a) sr(a) acha totalmente possível, possível, impossível ou totalmente impossível que o seu padrão de vida será melhor?

Avaliação retrospectiva (sociotrópica)

"Na sua sua opinião, a atual situação econômica do Brasil está melhor, igual ou pior, que há 10 anos?"

Identificação partidária

"Qual partido o(a) sr(a) gosta?"

Ascensão de classe

"Nos últimos anos, tem-se falado que muitas pessoas mudaram de classe social. Pensando nisso, considerando os últimos 8 anos, o(a) sr(a) diria que o(a) sr(a) e sua família mudaram de classe social ou permaneceram na mesma classe que estavam há 8 anos atrás?"

Personalismo

"Quero lembrar que, zero significa que o(a) sr(a) não gosta de jeito nenhum do político que vou mencionar e dez que o(a) sr(a) gosta muito. De novo, se o(a) sr(a) não conhecer o político que eu citar, diga apenas que não o conhece. Lula" 
Resultados da análise fatorial confirmatória, por ano

Tabela 25: Cultura Política 1993 e ESEB 2002

\begin{tabular}{|c|c|c|c|}
\hline \multicolumn{4}{|c|}{ Cultura Política 1993} \\
\hline & Economia & Social & Ordem \\
\hline Menos igualdade & 0.56 & & \\
\hline Leis/impostos contra empresas & 0.51 & & \\
\hline Mais liberdade empresários & 0.4 & & \\
\hline Menos serviços públicos & & 0.41 & \\
\hline Mulheres em casa & & 0.51 & \\
\hline Homossexualidade & & 0.56 & \\
\hline Aborto & & 0.49 & \\
\hline Contra manifestações & & & 0.56 \\
\hline Proibir protestos & & & 0.68 \\
\hline Proibir greves & & & 0.76 \\
\hline \multicolumn{4}{|c|}{ ESEB 2002} \\
\hline Controle serviços governo & 0.71 & & \\
\hline Controle preços governo & 0.62 & & \\
\hline Controle salários governo & 0.54 & & \\
\hline Homosexualidade & & 0.45 & \\
\hline Mulheres trabalhando & & 0.65 & \\
\hline Aborto & & 0.39 & \\
\hline Passeatas & & & 0.77 \\
\hline Greves & & & 0.66 \\
\hline Comícios & & & 0.64 \\
\hline
\end{tabular}


Tabela 26: ESEB 2006, LAPOP 2010 e LAPOP 2014

\begin{tabular}{|c|c|c|c|}
\hline \multicolumn{4}{|c|}{ LAPOP 2006} \\
\hline & Economia & Social & Ordem \\
\hline Liberdade empresas & 0.52 & & \\
\hline Menos serviços & 0.46 & & \\
\hline Menor intervenção governo & 0.41 & & \\
\hline Desigualdade não importa & 0.52 & & \\
\hline Homens adequados política & & 0.41 & \\
\hline Desemprego mulheres & & 0.43 & \\
\hline Homosexualidade & & 0.52 & \\
\hline Bloqueio ruas & & & 0.68 \\
\hline Manifestações permitidas & & & 0.61 \\
\hline Ocupações & & & 0.51 \\
\hline \multicolumn{4}{|c|}{ LAPOP 2010} \\
\hline Estado responsável bem-estar & 0.55 & & \\
\hline Estado responsável empregos & 0.47 & & \\
\hline Estado responsável aposentadoria & 0.6 & & \\
\hline Estado responsável saúde & & 0.47 & \\
\hline Homossexualidade (1) & & 0.38 & \\
\hline Homossexualidade (2) & & 0.45 & \\
\hline Racismo (1) & & 0.56 & \\
\hline Racismo (2) & & 0.52 & \\
\hline Manifestações & & & 0.67 \\
\hline Invasão propriedades & & & 0.68 \\
\hline Participação comunidades & & & 0.71 \\
\hline \multicolumn{4}{|c|}{ LAPOP 2014} \\
\hline Governo responsável todos & 0.45 & & \\
\hline Mais iniciativa privada & 0.56 & & \\
\hline Renda mais igualitária & 0.42 & & \\
\hline
\end{tabular}


Resultados Análise de Classes Latentes, por ano

Tabela 27: Cultura Política 1993

\begin{tabular}{|c|c|c|c|c|c|}
\hline & Esquerda & Moderados & Liberais & Comunitaristas & Conservadores \\
\hline \multicolumn{6}{|c|}{ Menos igualdade } \\
\hline Esquerda & $75 \%$ & $45 \%$ & $43 \%$ & $66 \%$ & $35 \%$ \\
\hline Centro & $11 \%$ & $34 \%$ & $09 \%$ & $26 \%$ & $10 \%$ \\
\hline Direita & $14 \%$ & $21 \%$ & $48 \%$ & $08 \%$ & $55 \%$ \\
\hline \multicolumn{6}{|c|}{ Liberdade empresas } \\
\hline Esquerda & $56 \%$ & $37 \%$ & $09 \%$ & $71 \%$ & $11 \%$ \\
\hline Centro & $28 \%$ & $40 \%$ & $26 \%$ & $24 \%$ & $17 \%$ \\
\hline Direita & $16 \%$ & $23 \%$ & $65 \%$ & $05 \%$ & $72 \%$ \\
\hline \multicolumn{6}{|c|}{ Homossexualidade } \\
\hline Esquerda & $61 \%$ & $24 \%$ & $35 \%$ & $12 \%$ & $05 \%$ \\
\hline Centro & $14 \%$ & $59 \%$ & $44 \%$ & $05 \%$ & $17 \%$ \\
\hline Direita & $25 \%$ & $17 \%$ & $21 \%$ & $83 \%$ & $78 \%$ \\
\hline \multicolumn{6}{|c|}{ Mulheres em casa } \\
\hline Esquerda & $73 \%$ & $43 \%$ & $56 \%$ & $23 \%$ & $21 \%$ \\
\hline Centro & $06 \%$ & $28 \%$ & $20 \%$ & $16 \%$ & $22 \%$ \\
\hline Direita & $21 \%$ & $28 \%$ & $23 \%$ & 61 & $56 \%$ \\
\hline \multicolumn{6}{|c|}{ Protestos } \\
\hline Esquerda & 67 & $34 \%$ & $23 \%$ & $22 \%$ & $17 \%$ \\
\hline Centro & $15 \%$ & $55 \%$ & $35 \%$ & $32 \%$ & $24 \%$ \\
\hline Direita & $17 \%$ & $11 \%$ & $42 \%$ & $46 \%$ & $59 \%$ \\
\hline \multicolumn{6}{|l|}{ Greves } \\
\hline Esquerda & $61 \%$ & $45 \%$ & $25 \%$ & $21 \%$ & $15 \%$ \\
\hline Centro & $22 \%$ & $33 \%$ & $36 \%$ & $31 \%$ & $11 \%$ \\
\hline Direita & $17 \%$ & $22 \%$ & $38 \%$ & $52 \%$ & $74 \%$ \\
\hline
\end{tabular}


Tabela 28: LAPOP 2006

\begin{tabular}{|c|c|c|c|c|c|}
\hline & Esquerda & Moderados & Liberais & Comunitaristas & Conservadores \\
\hline \multicolumn{6}{|c|}{ Menos intervenção economia } \\
\hline Esquerda & $64 \%$ & $33 \%$ & $19 \%$ & $71 \%$ & $82 \%$ \\
\hline Centro & $15 \%$ & $35 \%$ & $22 \%$ & $09 \%$ & $06 \%$ \\
\hline Direita & $21 \%$ & $32 \%$ & $59 \%$ & $20 \%$ & $12 \%$ \\
\hline \multicolumn{6}{|c|}{ Menos serviços públicos } \\
\hline Esquerda & $57 \%$ & $41 \%$ & $21 \%$ & $65 \%$ & $21 \%$ \\
\hline Centro & $30 \%$ & $45 \%$ & $15 \%$ & $20 \%$ & $06 \%$ \\
\hline Direita & $12 \%$ & $14 \%$ & $63 \%$ & $15 \%$ & $73 \%$ \\
\hline \multicolumn{6}{|c|}{ Homens adequados política } \\
\hline Esquerda & $48 \%$ & $11 \%$ & $46 \%$ & $32 \%$ & $28 \%$ \\
\hline Centro & $38 \%$ & $62 \%$ & $22 \%$ & $06 \%$ & $05 \%$ \\
\hline Direita & $24 \%$ & $27 \%$ & $32 \%$ & $62 \%$ & $67 \%$ \\
\hline \multicolumn{6}{|c|}{ Homossexualidade } \\
\hline Esquerda & $45 \%$ & $23 \%$ & $44 \%$ & $20 \%$ & $05 \%$ \\
\hline Centro & $24 \%$ & $25 \%$ & $15 \%$ & $02 \%$ & $11 \%$ \\
\hline Direita & $31 \%$ & $52 \%$ & $41 \%$ & $78 \%$ & $84 \%$ \\
\hline \multicolumn{6}{|c|}{ Ocupações } \\
\hline Esquerda & $49 \%$ & $33 \%$ & $36 \%$ & $09 \%$ & $19 \%$ \\
\hline Centro & $32 \%$ & $34 \%$ & $44 \%$ & $09 \%$ & $07 \%$ \\
\hline Direita & $19 \%$ & $33 \%$ & $20 \%$ & $82 \%$ & $74 \%$ \\
\hline \multicolumn{6}{|c|}{ Manifestações } \\
\hline Esquerda & $74 \%$ & $34 \%$ & $52 \%$ & $28 \%$ & $28 \%$ \\
\hline Centro & $11 \%$ & $44 \%$ & $16 \%$ & $19 \%$ & $26 \%$ \\
\hline Direita & $15 \%$ & $22 \%$ & $32 \%$ & $53 \%$ & $46 \%$ \\
\hline
\end{tabular}

